Florida International University FIU Digital Commons

\title{
Sociocultural Complexities of Ecosystem Restoration: Remaking Identity, Landscape and Belonging in the Florida Everglades
}

Rebecca I. Garvoille

Florida International University, rgarv001@fiu.edu

DOI: $10.25148 /$ etd.FI13042213

Follow this and additional works at: https://digitalcommons.fiu.edu/etd

\section{Recommended Citation}

Garvoille, Rebecca I., "Sociocultural Complexities of Ecosystem Restoration: Remaking Identity, Landscape and Belonging in the Florida Everglades" (2013). FIU Electronic Theses and Dissertations. 841.

https://digitalcommons.fiu.edu/etd/841 


\title{
FLORIDA INTERNATIONAL UNIVERSITY
}

Miami, Florida

SOCIOCULTURAL COMPLEXITIES OF ECOSYSTEM RESTORATION:

REMAKING IDENTITY, LANDSCAPE AND BELONGING IN

THE FLORIDA EVERGLADES

\author{
A dissertation submitted in partial fulfillment of \\ the requirements for the degree of \\ DOCTOR OF PHILOSOPHY \\ in \\ GLOBAL AND SOCIOCULTURAL STUDIES \\ by \\ Rebecca I. Garvoille
}

2013 
To: Dean Kenneth G. Furton

College of Arts and Sciences

This dissertation, written by Rebecca I. Garvoille, and entitled Sociocultural Complexities of Ecosystem Restoration: Remaking Identity, Landscape and Belonging in the Florida Everglades, having been approved in respect to style and intellectual content, is referred to you for judgment.

We have read this dissertation and recommend that it be approved.

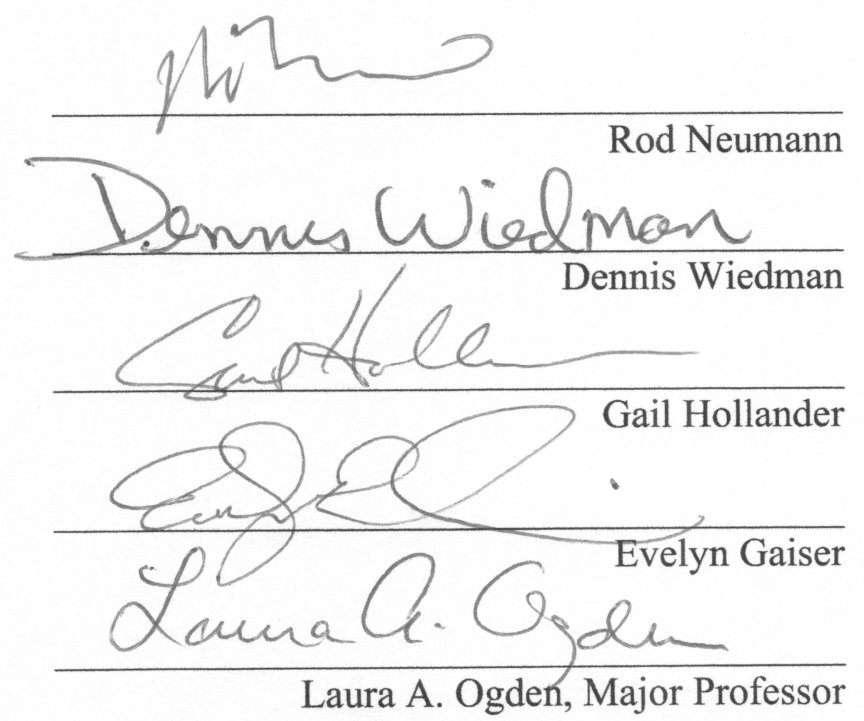

Date of Defense: March 26, 2013

The dissertation of Rebecca I. Garvoille is approved.

Dean Kenneth G. Furton

College of Arts and Sciences

Dean Lakshmi N. Reddi

University Graduate School

Florida International University, 2013 
(C) Copyright 2013 by Rebecca I. Garvoille

All rights reserved. 


\section{DEDICATION}

I dedicate my dissertation to my parents and to our home, Lost Horizon Farm, for sparking my intense interest in working landscapes and environmental conservation.

Thank you for your unwavering support throughout my intellectual journey. I also

dedicate my dissertation to my husband, Mike, for his endless patience and his enduring willingness to accompany me into the field with a smile. 


\section{ACKNOWLEDGMENTS}

I am indebted to my committee members for accompanying me on this intellectual journey, and for always encouraging me to be a better and more insightful scholar. Your incisive questions, good humor and helpful feedback were always welcome. I am especially grateful for all of the time and guidance my advisor, Dr. Laura Ogden, generously offered on researching, ethnographic interviewing, writing and revising along the way. I could not have completed this project without help from Bonnie Ciolino, Archivist at the South Florida Collections Management Center. Her keen knowledge of the Big Cypress papers was helpful on many occasions. I would also like to thank Robert Blythe, a retired National Park Service historian who is currently writing an administrative history of Everglades National Park. Robert provided me with several key archival references, and indispensable research tips along the way. My colleagues and mentors at the Florida Coastal Everglades LTER provided important feedback, an opportunity to learn more about Everglades ecology and hydrology, and a productive intellectual space in which to explore my ideas about the social nature of the Everglades. I would also like to thank the staff at Everglades National Park and the Big Cypress National Preserve for being receptive to my research and for responding to my many requests for interviews and information. Many, many thanks to all the glades hunters and glades people who opened their doors to me and granted me interviews during the course of my fieldwork. You literally opened my eyes to a wealth of human histories that animate the Everglades and make it a truly inspiring and fascinating place. I will always remember our compelling conversations about Everglades histories, politics and places; my swamp buggy rides; and my visits to your backcountry camps. And, finally, to R for 
illuminating my Everglades world with your interesting commentary, indispensible insights and inspiring words. I couldn't have done it without you.

This work would not have been possible without support from the National Science Foundation through the Florida Coastal Everglades Long-Term Ecological Research program (NSF Grant No. DBI-0620409), a National Science Foundation SBE Doctoral Dissertation Research Improvement Grant (NSF Grant No. BCS-1155026), a FIU Graduate School Dissertation Year Fellowship, a FIU Graduate School Doctoral Evidence Acquisition Fellowship, and a FIU Morris and Anita Broad Research Fellowship. 


\author{
ABSTRACT OF THE DISSERTATION \\ SOCIOCULTURAL COMPLEXITIES OF ECOSYSTEM RESTORATION: \\ REMAKING IDENTITY, LANDSCAPE AND BELONGING IN \\ THE FLORIDA EVERGLADES \\ by
}

Rebecca I. Garvoille

Florida International University, 2013

Miami, Florida

Professor Laura A. Ogden, Major Professor

The Florida Everglades is a highly diverse socionatural landscape that historically spanned much of the south Florida peninsula. Today, the Florida Everglades is an iconic but highly contested conservation landscape. It is the site of one of the world's largest publicly funded ecological restoration programs, estimated to cost over $\$ 8$ billion (U.S. GAO 2007), and it is home to over two million acres of federally protected lands, including the Big Cypress National Preserve and Everglades National Park. However, local people's values, practices and histories overlap and often conflict with the global and eco-centric values linked to Everglades environmental conservation efforts, sparking environmental conflict.

My dissertation research examined the cultural politics of nature associated with two Everglades conservation and ecological restoration projects: 1) the creation and stewardship of the Big Cypress National Preserve, and 2) the Tamiami Trail project at the northern boundary of Everglades National Park. Using multiple research methods including ethnographic fieldwork, archival research, participant observation, surveys and 
semi-structured interviews, I documented how these two projects have shaped environmental claims-making strategies to Everglades nature on the part of environmental NGOs, the National Park Service and local white outdoorsmen. In particular, I examined the emergence of an oppositional white identity called the Gladesmen Culture. My findings include the following: 1) just as different forms of nature are historically produced, contingent and power-laden, so too are different claims to Everglades nature; 2) identity politics are an integral dimension of Everglades environmental conflicts; and 3) the Big Cypress region's history and contemporary conflicts are shaped by the broader political economy of development in south Florida. My dissertation concluded that identity politics, class and property relations have played a key, although not always obvious, role in shaping Everglades history and environmental claims-making, and that they continue to influence contemporary Everglades environmental conflicts. 


\section{TABLE OF CONTENTS}

INTRODUCTION: The Socionatural Everglades .............................................

Research Goals and Objectives....................................8

Research Study Site ........................................................................ 9

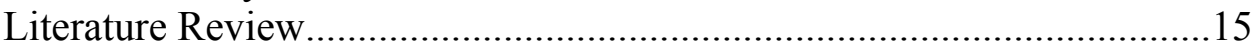

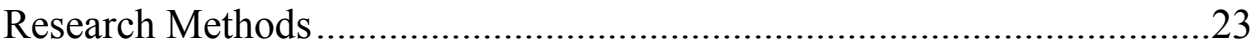

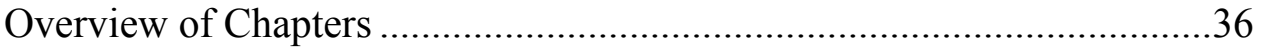

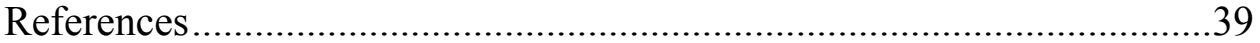

CHAPTER 1: Political Ecologies of Progress .......................................................46

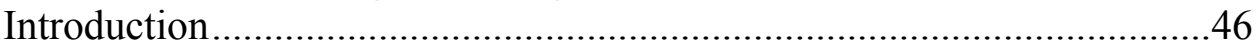

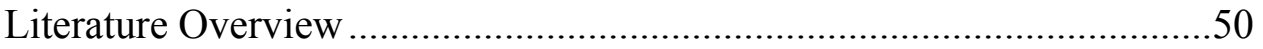

The Developmentalist Will to Improve: A More Productive

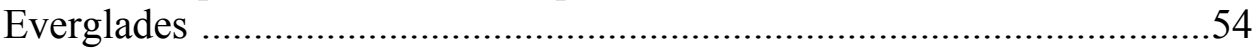

The Social Costs of Progress .................................................................60

An Enduring Developmentalist Will to Improve: The CS\&F Project, Post-

WWII Suburbia, and the Making the Big Cypress National Preserve ......69

Ecological Restoration: Rehabilitating and Redefining the Everglades ....79

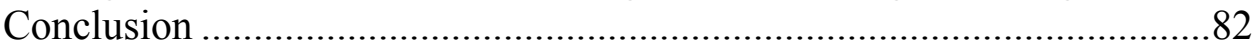

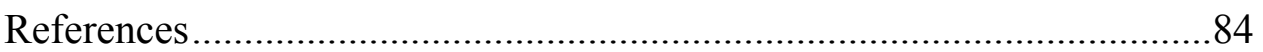

CHAPTER 2: Hydropolitics of Environmentalism in the Florida Everglades ......89

Defining Everglades Hydropolitics......................................................89

Background: Everglades Restoration, A Development Project.................91

The Rise of Everglades Environmental NGOs and the Everglades

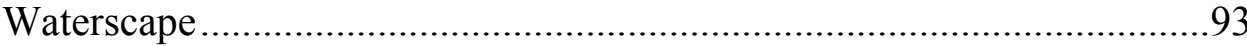

Water as Capital for ENGOs.............................................................107

Environmentalist Visions for Everglades Restoration ...........................110

The Devil is in the Details: Diverse Environmental NGO Positions on

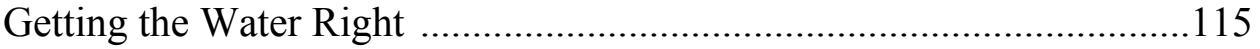

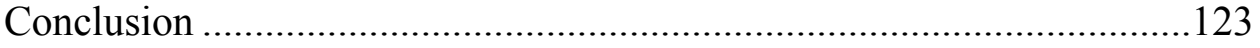

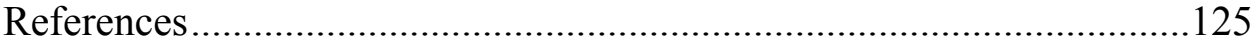

CHAPTER 3: A Hunter's Landscape - Place, Property and Practices in the Big

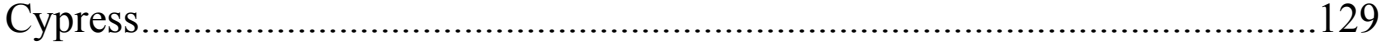

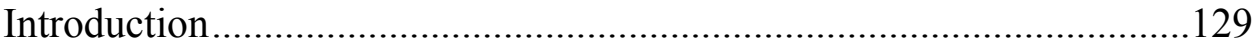

Cypress Country: An Overview .........................................................132

Property Relations and Ecology in Big Cypress Country.......................134

Landscape Practices in Big Cypress Country: The Emergence of A

Hunter's Landscape .......................................................................140

Entering a New Era of Land Relations and Real Estate Speculation ......153

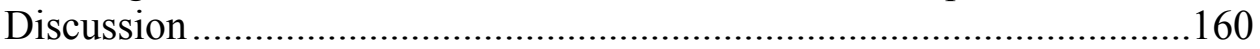

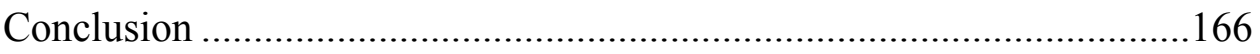


CHAPTER 4: The Politics of Place and Knowledge in the Big Cypress National

Preserve 169

Introduction. 169

Theoretical Orientation .......................................................................170

The Creation of the Big Cypress National Preserve: A Shifting Politics of

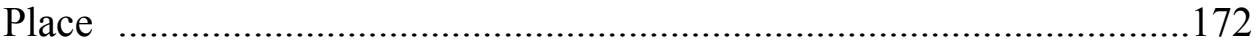

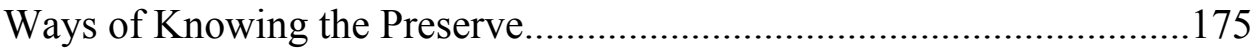

National Preserve Place-Making.............................................................175

The Documentary Realities of NPS Nature...........................................177

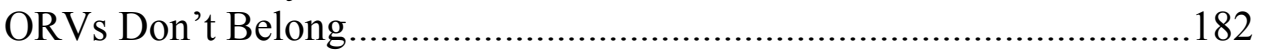

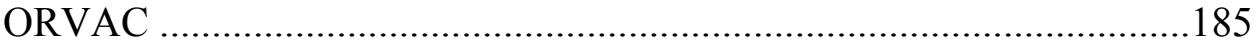

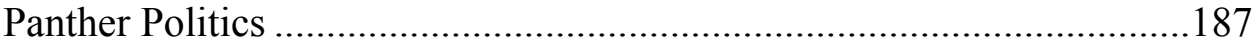

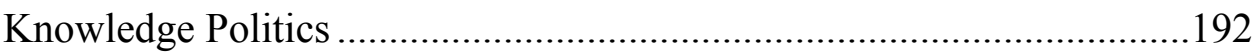

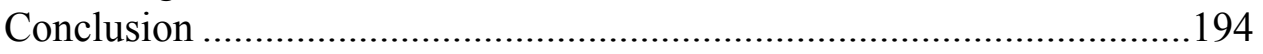

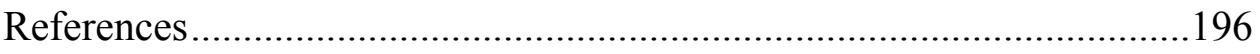

CHAPTER 5: The U.S. Army Corps of Engineers and the Sociopolitical

Complexities of Everglades Restoration.........................................................199

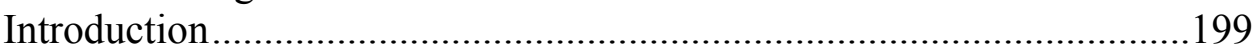

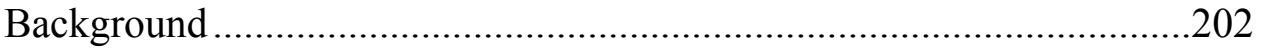

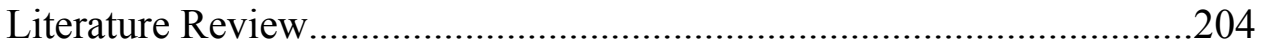

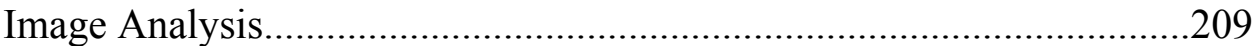

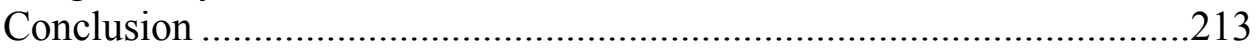

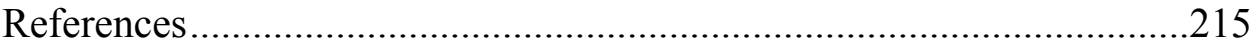

CHAPTER 6: The Cultural Politics of Nature: The Rise of the Gladesmen Folk

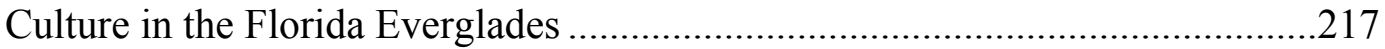

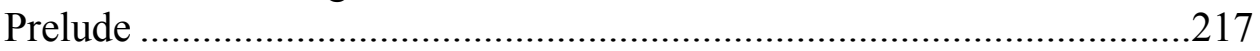

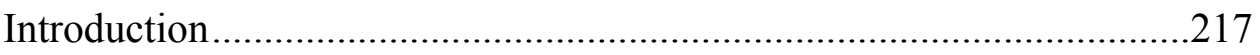

Landscape Politics and Culture Collide: The Gladesmen Identity

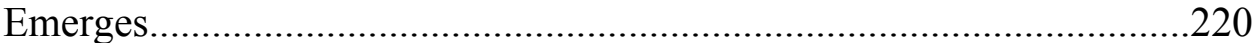

How the Gladesmen Identity Works.....................................................2232

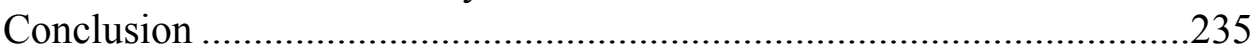

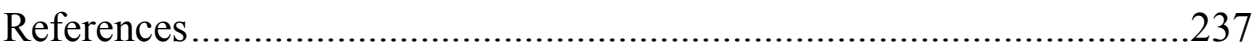

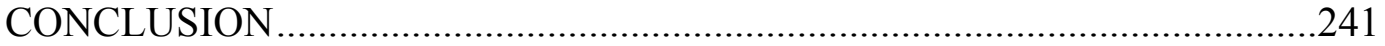

Emerging Landscapes, Emerging Subjectivities: Environmental

Conservation and the Politics of Nature in the Florida Everglades and

Beyond ...........................................................................................241

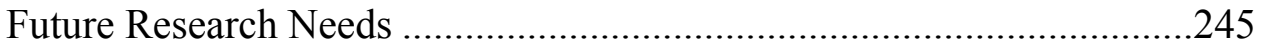

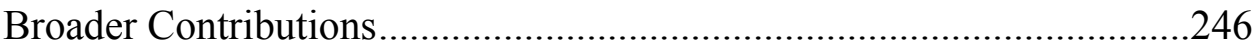

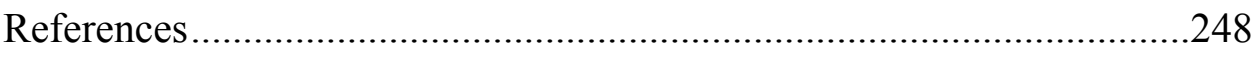

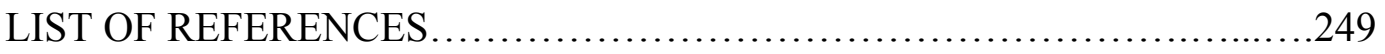




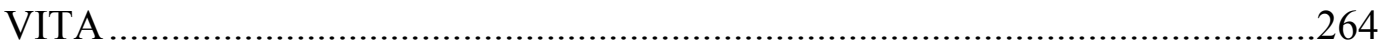




\section{Introduction: The Socionatural Everglades}

The Everglades is a complicated socio-ecological water-world whose layers unfold only with time, patience and the ability to look past the discursive mythology of a pristine and essential nature. In the words of Edward Casey (1996), the Everglades "gathers" rich stories about people and place besides the stories so often featured in the news media and on interpretative signage detailing the wetland's impressive natural history or its present-day hydrological importance. Finding these alternate glades (hi)stories requires digging deep below popular narratives about the Everglades to locate other voices and stories, including those of savvy outdoorsmen ${ }^{1}$, Native Floridians and Native Americans. In fact, many of these (hi)stories remain undiscovered because they are peripheral to contemporary ways of understanding the Everglades as a one-of-a-kind ecosystem undergoing ecological restoration, and as a iconic conservation landscape. I am particularly interested in what is lost or obscured when landscapes like the Everglades become iconic conservation hot-spots and are "scaled up" for global consumption by environmentalist publics and eco-tourists as biological wonders.

\footnotetext{
${ }^{1}$ While other authors, who have written about cultural history and the politics of nature in the Everglades, use the term gladesmen to describe the region's white hunters (e.g., Simmons and Ogden 1998, Ogden 2011), I have chosen to use the term outdoorsmen instead to refer to the communities of white hunters, woodsmen and backcountry camp owners I interviewed and spent time with in the southern Everglades. As I explain in greater detail below, the term outdoorsmen resonates as a broader and better descriptor of the wide array of 'glades users I interacted with during my field research.
} 
Figure 1: The Historic and the Contemporary Florida Everglades
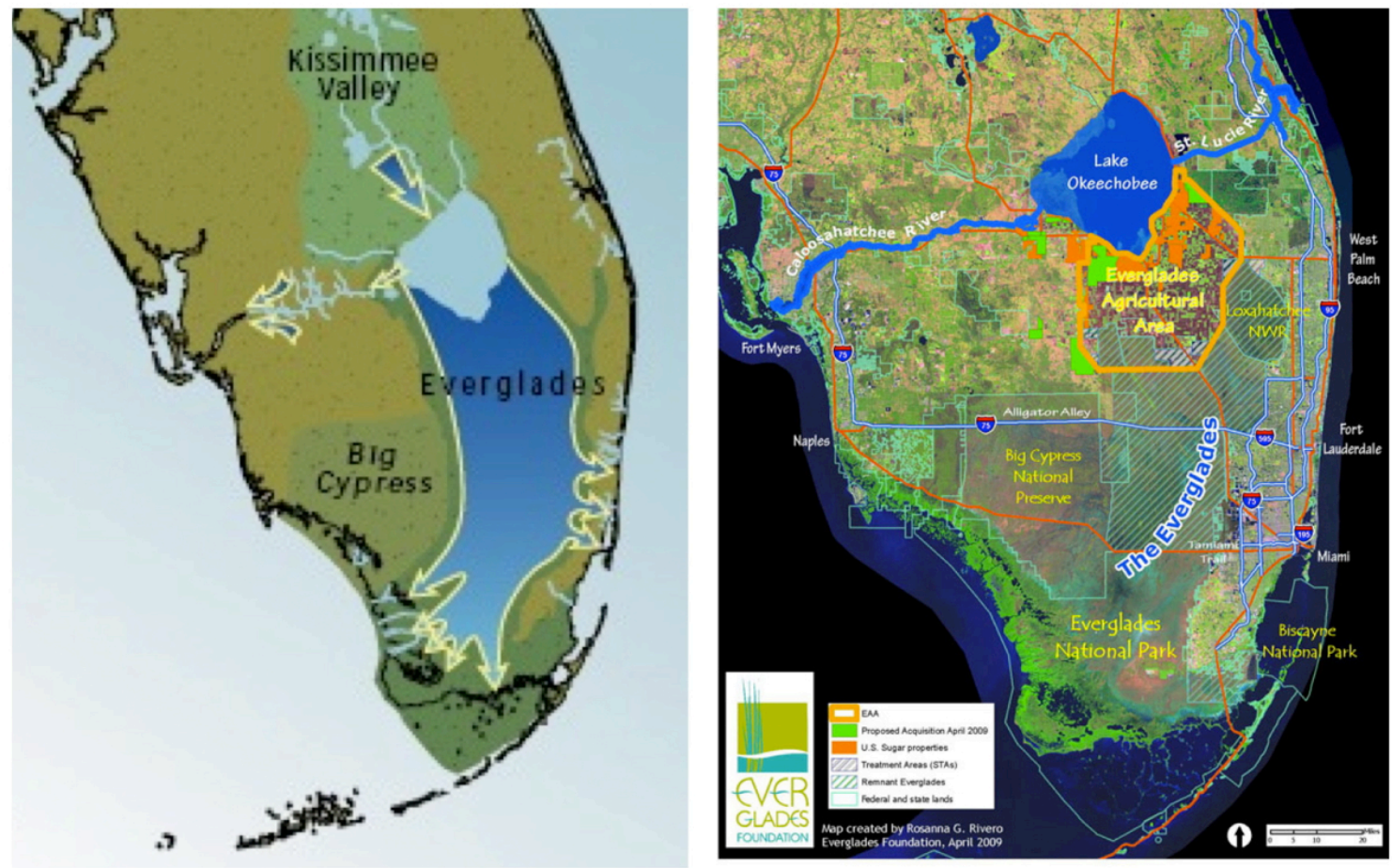

The left-hand panel depicts the spatial extent of the pre-drainage or historic Everglades, which encompassed much of southern Florida before the region's widespread development. The historic Everglades stretched from the Kissimmee Chain of Lakes across Lake Okeechobee to the shores of Florida Bay. The right-hand panel illustrates the spatial extent of the contemporary Everglades. The contemporary Everglades is one-half its historic size and fragmented by coastal and interior agricultural development.

I remember the first time I looked out over the Everglades during a weekend field trip to Everglades National Park with my husband. I had recently moved to south Florida from the shrub-steppe landscape of North Central Washington, and I was eager to experience the world-renowned wetland I had heard so much about. That day at the Park, I had a small black notebook in hand, ready to jot field notes about graceful wading birds or intriguing aquatic plant species. I vividly recall standing on the wooden boardwalk at the Pahayokee Overlook located several miles into the Park, which affords stunning vistas of an expansive and windswept sawgrass prairie dotted with dwarf cypress trees. The Payhayokee Overlook also includes interpretative signage about the Everglades' 
cultural importance to Native Americans, early settlers and local people like the wellknown alligator hunter, Glen Simmons. Yet, when I looked at the Everglades that afternoon, I saw it through the eyes of a tourist and park visitor enthralled with nature as visual scenery and biological wonder. Even though I had read the interpretative sign addressing the site's cultural history, I was looking at the Everglades as aesthetically and biologically valuable. I found myself caught up in the powerful discursive spell cast by the news media and Everglades-related publications of all kinds, which emphasize the Everglades' identity as an endangered, ecologically valuable, and globally significant wetland. My experiences that day demonstrate that we must pay attention to how our way of seeing a landscape is shaped by the powerful claims and representations of others. As many scholars have observed, landscapes are cultural products and productions. Nature as we know it, experience it and imagine it is not unmitigated but an effect of cultural imagination, scientific production and power (Mitchell 2002, Braun 2002). Our encounters with "nature" are entangled with scientific discourses about biodiversity, compelling television documentaries and online commentaries that showcase colorful accounts of a landscape's scenic beauty, and our own social positionings.

While the Everglades is a biological marvel - a one-of-a-kind oligotrophic wetland rich with scientific wonder, and a globally renowned World Heritage Site - it is also an incredibly rich socionatural landscape. The Everglades is a product of complex historical interactions between people and nature over time, and it is a place that has given rise to unique practices, identities and place attachments among local glades people and Native Americans that also deserve to be brought to light. When I look at the Everglades now - and the more I learn about its history as a Native American homeland, 
as a re-engineered wetland whose drainage was central to south Florida's development, and as the anchor for unique rural lifeways - I see this wetland as an example of what Bruce Braun (2002) has called "social nature." The Everglades is not simply an object external to people, history and social life for visual consumption but a textured and ongoing product of social relations. The Everglades is undeniably entangled in and produced by multiple social worlds ranging from nature photography, to environmental conservation, to oil extraction to agriculture to real estate development. As Bruce Braun $(2002,13)$ reminds us, understanding nature as social, "rather than a pure identity external to society, forces us to take responsibility for how this remaking of nature occurs, in whose interests and with what consequences (for people, plants and animals alike)." In this way, the analytic of social nature enables us to "render strange" the category of nature, compelling us to examine the power effects, claims, practices and multi-species relations that produce it.

Using the analytic of social nature in my dissertation allows me to consider the Everglades as an emergent landscape produced by specific social, technological and ecological imperatives - all with uneven socio-natural consequences (Braun 2002, Harvey 1996). The Everglades that appears in my dissertation is an object of political, aesthetic and economic calculation that has come into being through unique claims-making processes and uneven power relations between humans, plants, animals, technologies and other non-humans.

Recent scholarship in environmental anthropology and human geography has demonstrated that the social conflict and resistance to environmental conservation projects are a form of cultural politics shaped by uneven, historically-constituted power 
relations (Braun 2002, Nadasdy 2003, Igoe 2004, Walley 2004, Haenn 2005, Kosek 2006, West 2006, Li 2007, Cattelino 2009, Heatherington 2010, Ogden 2011). These scholars point out: 1) that environmental conservation projects often prompt the emergence and formalization of individual and collective identities as a means of environmental claims-making, 2) that environmental conservation projects portray and spatialize landscapes and landscape histories in accordance with "virtualizing visions" of pristine nature (Carrier and West 2004), creating a certain moral politics of belonging, and 3) that contemporary environmental conservation projects are layered onto and shaped by the social and material legacies of past development projects.

Contemporary scholarship in environmental anthropology and human geography frames "nature" as a complex, emergent and historically contingent assemblage of humans and nonhumans (Deleuze and Guattari 1987, Braun 2002, DeLanda 2006, Haraway 2008, Ogden 2011), both created and transformed by the shifting imperatives of environmental conservation. As DeLanda observes, assemblages are "wholes whose properties emerge from the interaction between parts" $(2006,5)$. The theoretical concept of an assemblage is useful because it points to dynamism inherent in the associations between human and non-humans sparked by environmental conservation efforts, and to the ways in which these associations make worlds. For example, in his book on the political life of forests in northern New Mexico, Jake Kosek (2006) describes how different periods in forest conservation policy prompted the emergence of new constellations of actors around new set of forest facts and priorities. Kosek describes how these forest policies were "eventful" because they sparked novel alliances between and among humans and nonhumans. These policies, especially species conservation efforts in 
the 1990s, drew together and created tensions between environmentalists, local Hispanos and government staff along fresh lines. These events shifted the existing power dynamics of actors invested in the fate of the pinyon-juniper forests too - with the U.S. Forest Service re-emerging from bureaucratic obscurity as a key player. Yet, Kosek also reminds us how such assemblages are dynamic and ephemeral. He closes his book with a vignette about the startling ways the pine bark beetle has decimated the pinon-juniper trees so hotly debated in earlier forest conservation struggles in northern New Mexico, and markedly changed the material and discursive topography of environmental struggle there.

However, the literature on social nature has less to say about how environmental claims-making - as a process integral to environmental conservation initiatives - plays a key role in shaping the assemblages created by such projects, and in driving shifts in the composition of such assemblages over time and space. Understanding processes of environmental claims-making matters all the more as scholars focus on understanding the relationality and contingency of nature (rather than its timeless purity) including the shifting coalitions of actors that form around its defense (Brosius 1999), its hidden humanity (Ogden 2011), and why the goals of environmental conservation projects often remain unrealized (Carrier and West 2004, Mathews 2011). More anthropological work needs to be done on mapping the claims to nature produced through environmental conservation projects and on documenting what they reveal about who benefits and who does not from the remaking of landscapes by conservation imperatives as well as the uneven topographies of power that inform conservation projects. In particular, scholars must attend to how identities and place attachments are renegotiated in the context of 
environmental conservation (West, Igoe and Brockington 2006), and how environmental conservation projects, including ecosystem restoration initiatives, are the site of intense social struggles over defining the proper place for humans in nature (Higgs 2003).

My dissertation addresses this gap. My work examines how Everglades conservation and ecological restoration interventions have given rise to environmental claims-making strategies to the Florida Everglades on the part of environmental NGOs, the National Park Service and local people. Just as different forms of nature are historically produced, contingent and power-laden, so too are different claims to nature. In the chapters ahead, I critically detail the historical, material and socio-political processes through which different claims (and counter-claims) to the Everglades have emerged and are contested in the context of Everglades restoration and conservation initiatives, and how different actors leverage certain claims to occupy positions of power as environmental "trustees 2 ." Specifically, I examine the claims made by actors ranging from early Everglades land barons to environmental NGOs to local people to government agencies. I investigate how these claims have come into being, and are challenged over time. I also attend to how claims making (premised on virtualizing notions of pristine and productive nature) plays an important role in displacing some actors while emplacing and empowering others. Yet, I also demonstrate how such virtualizing visions remain incomplete and leave room for challenge by counter-claims, such as the emergent and oppositional white identity that outdoorsmen in the Florida Everglades call the

\footnotetext{
2 Throughout my dissertation I use the term trustee and trusteeship in the senses defined by Tanya Li in her 2007 monograph, The Will to Improve. Li defines trusteeship in the context of environmental conservation projects as a position of power made possible by technoscientific knowledge, which enables certain actors to make compelling claims about the nature of environmental problems and their solutions. Such claims often by marginalize local claims and contexts.
} 
Gladesmen Culture. Specifically, this dissertation demonstrates that identity politics are an integral dimension of Everglades history and claims-making, and that identity politics continue to shape Everglades protection and restoration projects.

In the following sections of this Introduction, I provide an overview of my research goals and objectives, study site, relevant literature, research methodology and dissertation chapter topics. First, I detail my dissertation's research goals and objectives, outlining my project's guiding research questions. Then, I describe my research site in the southern Florida Everglades and outline its significance for studying the intersections between identity politics and environmental conservation. Next, I discuss the literatures in anthropology and geography that inform my dissertation: political ecology, place, the human dimensions of protected areas and Everglades history and culture. I then explain my research approach and research methodology. I conclude with a summary of each of my dissertation chapter's key arguments.

\section{Research Goals and Objectives}

The primary goal of my dissertation was to investigate emergent processes of environmental governance, environmental claims-making and environmental subjectmaking shaped by environmental conservation and restoration efforts in the Florida Everglades. My dissertation documents how the multi-billion dollar efforts to protect and restore Everglades biodiversity have reshaped identities, land and water management strategies and landscape claims in southern Florida, and what this has meant for local people traditionally associated with the southern Everglades. 
Three central research questions guided this work:

Q1. How have Everglades environmental conservation projects changed the way the southern Everglades is conceptualized as a place, and how have these perspectives influenced land and water management strategies as well as ideas about people's "proper" relationship with nature?

Q2. What is the contemporary "Gladesman" identity, and how and why did it originate? In what ways do environmental organizations, other local peoples and federal resource management agency staff challenge it?

Q3. What claims to nature and place, and claims-making strategies, have emerged on the part of the National Park Service, environmental NGOs and white outdoorsmen through struggles over environmental conservation in the southern Everglades?

\section{Research Study Site}

The Florida Everglades is a highly diverse socionatural wetland that encompasses much of the south Florida peninsula, spanning across the Kissimmee prairies and finger lakes into the open waters of interior Lake Okeechobee and then arching south-southwest across the sugar cane fields, sawgrass marshes, cypress domes, pine rocklands and coastal mangroves of the southern Everglades region (Lodge 2004). Perhaps because approximately half of its historic extent has been lost to drainage and development, the Florida Everglades is today an iconic conservation landscape, including over 2 million areas of federally protected land (for a history of Everglades transformations, see Derr 
1997, McCally 1999, Grunwald 2006, Hollander 2008, Ogden 2011). The Everglades is also the site of a long-term, high profile and multi-billion dollar restoration effort that seeks to re-engineer an 18,000 square mile watershed (U.S. GAO 2007), and whose completion is heralded by the federal government and environmental NGOs alike. Yet, the Florida Everglades like all landscapes emerges out of multiple, sometimes contradictory, histories and meanings. The Everglades has given rise to distinct kinds of local landscape meanings, practices and place attachments, or what anthropologist Clifford Geertz (1977) would term "webs of significance,” forged through diverse human interactions with its many environments as generations of people have hunted, fished, recreated and subsisted in places like the Big Cypress Swamp and Fisheating Creek. These different landscape meanings and lifeways overlap and sometimes conflict with the ecocentric values linked to the Everglades as an object of ecosystem restoration and environmental conservation, resulting in a highly contested landscape where different social groups debate the goals, meanings and benefits of these projects.

In this dissertation, I focus on three key environmental themes - environmental subjectivities, environmental governance, and environmental claims-making - and how they intersect with the politics of nature. In particular, I focus on the identity politics surrounding Everglades environmental conservation, tracing white outdoorsmen's claims-making strategies, including the formalization of an oppositional place-based identity that white outdoorsmen have termed the Gladesmen culture, and their reactions to conservation and restoration interventions in the southern Everglades. 
I now turn to one important clarification on terminology. In the contemporary moment, a subset of white outdoorsmen rally behind the moniker, the Gladesmen culture, to draw greater attention to their unique uses of and attachments to the Everglades as well as to emphasize their human histories in the Everglades in policy and media circles. These outdoorsmen self-identify as Gladesmen, in part, to make a political statement about the ways they belong in the contemporary Everglades. I describe the rise of this Gladesmen culture in Chapter 6. Other scholars too have used the term gladesmen to describe a historic community of poor, rural, white hunters with unique place-based attachments to the Everglades (e.g., Simmons and Ogden 1998, Ogden 2011).

In my research, I choose to use the term outdoorsmen to describe the communities of white hunters, woodsmen and backcountry camp owners I interviewed and spent time with in the southern Everglades. While I support the ways the term Gladesmen has come to signal a deep, lived and unique place attachment to the Everglades, provides a window into the human history of the Everglades, and functions as a symbol used to call attention to the human dimensions of the Everglades in contemporary ecological restoration debates, I feel uncomfortable using the term Gladesmen as a general descriptor of the all the local people I worked in my research. Many people I interviewed voiced mixed reactions to this term and some were visibly reluctant to use this term to describe their lives in the Everglades. They had a variety of objections, and some offered alternative characterizations of themselves as "Florida crackers", or "swampers" - contestations which I describe in greater detail in Chapter 6. While many of the people (mostly men) I worked with were hunters, they also spent time in the Everglades engaged in a variety of other activities including stargazing, backcountry exploration, and spending time outside 
in the backcountry with their friends and families. Thus, the term "white hunters" does not accurately encompass their diverse Everglades experiences and practices either. In effect, the label outdoorsmen resonates as a broader and better narrative device for portraying the wide array of 'glades users I spoke to and interacted with during my field research. This term captures their longevity in the landscape, and their multi-faceted love of being outdoors in the Everglades while leaving room for the multiple ways in which they define their own identities (and sometimes contest the term Gladesmen). What's more, I prefer the term outdoorsmen to sportsmen because, for many of the people I interviewed, spending time out in cypress country is not a recreational sport in the traditional sense, but a way of life tied to a specific place and practiced by people across multiple socio-economic strata. For them, the Everglades emerges as a place that is foundational to their identities and their engagements with modern Florida.

While white outdoorsmen's (and native peoples) identities have remained rooted to the Everglades, Everglades' habitats and water flows have changed significantly as a result of wetland drainage and subsequent ecological restoration. Everglades restoration first began in earnest in the early 1970s when the deleterious environmental effects of south Florida's earlier wetland reclamation efforts commanded public attention and action. Soon thereafter, Congress authorized the creation of the Big Cypress National Preserve in 1974, and then the 1989 Modified Water Deliveries project to convey more freshwater into Everglades National Park. Congress approved these efforts as a means to rehabilitate the southern Everglades. Contemporary Everglades restoration focuses on restoring the hydrology of the Everglades watershed to pre-drainage conditions (U.S. GAO 2007, Doyle 2008). These restoration initiatives, with their focus on "getting the 
water right," have changed the way the Everglades is managed and understood as a place, recasting it as a water management system and raising new questions about the proper place for people in this waterscape (Ogden 2008a). Yet, the majority of literature on Everglades restoration takes a narrow view of restoration as a principally ecological, legal and technical process (e.g. Clarke and Dalrymple 2003, Grunwald 2006, Light 2006; NAS 2008, 2010, 2012), largely ignoring how Everglades restoration is the site of potent social struggles and uneven power relations that seek to define the proper boundaries between people and nature.

Nor does this body of scholarship carefully consider the legacies of the social marginalization of poor rural whites and indigenous peoples so intimately intertwined with the history of the southern Everglades. Scholars have poignantly described the Seminole peoples' violent arrival in the southern Everglades (tied to the bloody history of U.S. Indian removal), as well as documented the ways Seminole peoples were marginalized by non-Indians during Everglades reclamation, enclosure and restoration (Tebeau 1968, Kersey 1975, West 1998, Buffalo Tiger and Kersey 2002, Cattelino 2008, Wiedman 2010). The creation of Everglades National Park in 1947 further relegated Seminole people to the economic and cultural margins of south Florida. The Park dispossessed Seminole peoples of their land and outlawed many of their traditional practices. These social injustices persist into the present as part of an ongoing struggle over land rights between the Seminole peoples residing in the Everglades and the U.S. Department of the Interior.

Everglades National Park precipitated other complex social impacts to rural white glades people, ending alligator hunting as a lifeway and livelihood strategy (Ogden 2011, 
Keller and Turek 1998). Scholars have begun to examine these hidden human histories as well as the exclusionary techno-scientific focus of Everglades restoration (Cattelino 2008, 2009; Ogden 2008a), how environmentalist battles against sugar corporations efface small farmers from portraits of the Everglades Agricultural Area (Hollander 2008) and how Seminole and Miccosukee peoples reassert their sovereignty and indigeneity through Everglades restoration (Cattelino 2009) and ecotourism (Wiedman 2010). Certainly, territorial tensions and epistemic erasures (Braun 2002) of local people and their practices persist in Everglades restoration. My dissertation research brings additional depth and specificity to the arguments scholars Ogden, Hollander and Cattelino advance about the exclusionary politics of Everglades restoration by providing an in-depth examination of the particular social struggles associated with two contemporary conservation and restoration projects in the southern Everglades. My work addresses the ways in which local outdoorsmen have understood, contested and reshaped these projects, which are premised on modernist ideas about science and progress.

These factors make the Everglades an ideal setting in which to study "the politics of nature" (Ogden 2011) that have unfolded over decades between the state, local people and environmental NGOs. What makes the southern Everglades (the site of this research) all the more interesting is that the logics of ecosystem restoration are overlaid on a landscape defined by two national park units, each with their own ecologies and politics Everglades National Park and Big Cypress National Preserve - creating a unique research context. 


\section{Literature Review}

My dissertation contributes to scholarship in anthropology and geography on the politics of nature associated with environmental conservation and restoration projects. It draws on political ecology, as well as related scholarship on place and power and on parks and peoples, to provide new insights into the cultural politics and power dynamics shaping environmental subjectivities, environmental governance, and environmental claims making in the Florida Everglades. In the following section, I present an overview of the relevant literature, highlighting the specific contributions my dissertation makes to this scholarship.

\section{Political Ecology}

Political ecology comprises a diverse body of theory and analysis (Robbins 2004, Neumann 2005) and offers an important critical approach for understanding environmental politics. One line of scholarship in political ecology draws on Michel Foucault's concepts of governmentality (2000 [1994]) and genealogy (1977) to critique and explore the uneven spatial and social relations produced by environmental conservation projects. Foucault's work has decentered the notion that the state is the sole site of power and instead opened up new ways of thinking about power as fluid, diffuse historically-contingent and generative.

Importantly, political ecology creates a framework for understanding how Foucault's ideas about power intersect with struggles over nature. Political ecology scholars have attended to the productive and non-totalizing aspects of power, its historical contingency, as well as the way it creates social inequalities in environmental 
projects. The more recent "environmentality" literature (Agrawal 2005) frames environmental conservation projects as technologies of government, and examines these projects as one of many ways for disciplining practices and ecologies so as to bring about the proper relations between people and things (e.g., Agrawal 2005, Kosek 2006, Li 2007). The environmentality literature attends to how such projects produce new institutional arrangements, territories, identities and social relations (Agrawal 2005, Moore 2005, Kosek 2006, Li 2007). Specifically, Tanya Li (2007) attends to how environmental conservation projects give rise to unequal power relations between environmental NGOs and local people, premised on who occupies the role of environmental trusteeship. Li defines trusteeship as a position of power that affords certain development actors that right to intervene in the lives of others. Trusteeship, Li explains, is premised on technoscientific ways of knowing. In her analysis of the politics surrounding Lore Lindu National Park, Li documents how environmental NGOs become environmental trustees by leveraging their techno-scientific expertise to define the environmental problems at hand, and then to offer their skills as the only rational solution. Li builds on Foucault's ideas about the openings and closings of power (its nontotalizing aspects) to show how environmental trusteeship remains open to challenge from those who lives are reshaped by environmental trustees and the imperatives of environmental conservation.

With its emphasis on power relations, political ecology makes an important move beyond analytical frameworks that describe environmental politics as straightforward debates between stakeholders with divergent interests (as has been done in numerous other accounts of environmental conflict, which assume a static group of stakeholders 
over time). Instead, political ecologists take a broader and deeper view of environmental politics, and examine them as the struggle between a diverse field of unevenly positioned actors for control over a local environment, mediated by unequal power relations and cultural politics (Bryant and Bailey 1997; Peet and Watts 2004, Neumann 2005, Biersack 2006). Political ecologists have shown that scholars must be attuned to how actor positions came into being, and how they are premised on unequal power relations, different epistemologies and divergent visions of nature (Braun 2002).

Political ecologists have also foregrounded the important notion that nature is hybrid, or an assemblage created by relations between humans and non-humans. That is, political ecologists are increasingly interested in how humans and non-humans come together to make worlds (Mathews 2011). Thus, instead of conceiving of nature as "simply the object over which politics happens" (Braun 2002) or as a purely biophysical space, political ecologists are interested in nature as a socio-historical product. They examine nature as an object actively produced by human conceptualizations, activities and regulations as well as by ecological processes (Biersack 2006). In this way, nature is not something that is external to, independent of and prior to culture and human activity. Instead, political ecologists argue that nature is an artifact of human activity and meaning-making. As Bruce Braun summarizes, nature is: “...an object of economic and political calculation...made, materially and semiotically by multiple actors and through many different historical and spatial practices" (Braun 2002, 3).

\section{Place and Power}

The idea of place is an important analytic for thinking through the multiple and 
complex attachments people have to landscapes (Feld and Basso 1996) and how these can come into conflict when managing public lands (Yung, Freimund and Belsky 2003), especially as landscapes transition into ecologically valuable places (Ogden 2008, Ogden 2011). Sense of place becomes particularly central when examining people's relationships - political, experiential, scientific, social, linguistic, emotional - to a piece of ground and to understanding how that landscape's meaning and significance changes over time, depending on who controls it.

While some scholars have questioned whether or not place remains a useful analytic, others like Arturo Escobar show how place is indispensable to contemporary analyses of human-environment interactions. As Escobar (2008) articulates in his latest book, "...the struggle over place has not become meaningless and has not ended [in modernity]." Instead, places continue to act as the "sites of dynamic cultures, economies and environments and are not just nodes in a global capitalist system" (Escobar 2008, 67). Places continue to be important conjunctures of local-global social relations (Tsing 2005) and loci of enduring intimate attachments to land (Basso 1996, Moore 2005, Escobar 2008), provoking political struggle in contests over their future, especially in the context of environmental conservation projects. This is certainly the case in the Florida Everglades, where state and environmental NGO narratives have recast the Everglades as part of the nation's natural heritage, and marginalized the local landscape attachments, histories and practices of white outdoorsmen.

As Edward Casey (1996) describes it, place is a complex configuration of objects gathered and held together in a particular way. Part of what gives a place its unique "sense of place" is the specific combination of objects that are gathered there, how they 
are ordered, and how that ordering is assigned meaning. Casey explains that places hold together people, memories, histories, experiences, material objects and landscape features and create a sense of order about how things are $(1996,25)$. Casey (1996) continues, "Th[is] arrangement allows for certain things - people, ideas, so forth - to overlap with and sometimes to occlude others as they recede." Thus, place is central to examining the way outdoorsmen understand the Big Cypress region as a configurative complex of things and how the creation of the Big Cypress National Preserve re-ordered those things and created tensions between the way outdoorsmen understand the Big Cypress region and the way other actors like environmental NGOs see it as a place". Such a "politics of place" is concerned with "different and potentially conflicting meanings" associated with a particular area and "how senses of place may be connected to larger political struggles" (Yung, Freimund and Belsky 2003, 855). For example, as Yung et. al observe, a social group's sense of place is a reflection of how that group is enmeshed in a region's broader political economy.

Moreover, place as an analytic helps to mediate some of the scalar confusions and complexities introduced by political ecology. In recent years, political ecology has shifted its focus to examining local-global articulations, or the coming together of local practices and lifeways with larger structures and processes like colonialism, modernity and

\footnotetext{
3 A note on terminology: Throughout my dissertation, I use the terms "the Big Cypress region" and "cypress country" interchangeably to describe the broader forested wetland that extends beyond the administrative boundaries of the Big Cypress National Preserve - an area that was historically known and used by many outdoorsmen prior to 1974. I use the term Big Cypress National Preserve to refer to the protected area owned by the National Park Service since 1974. I use the abbreviation BICY as shorthand for the Big Cypress National Preserve. I use the term "national preserve" to refer to the unique category of National Park Service (NPS) unit created by Congress in 1974, which permits uses not traditionally allowed on national parklands, such as hunting. The Big Cypress National Preserve was the nation's first national preserve.
} 
capitalism (Biersack 2006, 11-12). However, political ecology is not always clear on how to analyze such multi-scalar intersections, especially if a verticality of scale is presumed. Place offers a way of examining the ways particular assemblages of humans and nonhumans come together over a particular patch of earth, and articulate with more global processes. Biersack $(2006,15)$ writes: "In this effort to reconceptualize globalizing processes in nonvertical terms the word that gathers momentum is place...the grounded site of local-global articulation and interaction....Places are nodes within relational fields - sites of local-global articulation. If we now ask: Where is place? the answer is clearly both locational and relational." Donald Moore further elaborates: place is "never simply local, sealed off from an outside beyond" (1998: 347), and to study place is to "move from hermetically sealed sites of autonomy to relational spaces of connection and articulation" (1998: 347).” As Biersack concludes, "Places, in short, are constructed historically in processes that spatially exceed the local and in which the extralocal is as constitutive as the local." $(2006,16)$. Thus, "The concept of place is thus suitable for a political ecology that breaks with the 'overdeterminations of a distinct 'global'"(Raffles 1999:350). A place-based approach is helpful in this regard because it acknowledges the distribution of power and the presence of grassroots agents - as subjects of their own history and geography - instead of presuming a concentration of totalizing, top-down power in one end of the familiar binaries of modernism (civilized/uncivilized, local/global, traditional/modern). Moreover, place serves as a way of talking about the lived dimensions of particular ecologies (bodily practices, sensory experience, the lived physicality/materiality of a particular ecology), and how those become important to the making of environmental claims and identities. 
Yet place scholars like Casey do not adequately explain how certain assemblages of humans and nonhumans and their articulations come into being (other than through the living-moving body). Because of place's ongoing constitution and description, Casey observes "places not only are, they happen" $(1996,27)$. While place is an ongoing process it is not sui generis. Political ecology becomes important to the discussion of place because draws our attention to the role of power in place-making. Underscoring the need to document how power operates, political ecology turns our attention to examining how some actors have a greater ability to shape assemblages of things and their meanings (place) over time, and to influence what configurations come to the foreground. In summary, political ecology scholarship has shown how place is a product of power (e.g. Neumann 1998, Moore 1998, Braun 2002, Kosek 2006, Hollander 2008, Ogden 2011).

People's relations to place are structured by power relations as well as memory and meaning (Gupta and Ferguson 1997, Braun 2002, Strang 2003, Kosek 2006, Ogden 2011). Because not everyone has equal power to interpret a landscape's history or direct its management, who owns a landscape and the ideas governing it become a key factor in shaping its "material face," (see Olwig 2002) including its cultural preservation. A land's "owner," (especially in the US context) through their actions, interpretations, and bureaucratic structures may efface other stories and structures from a landscape that form the basis of identity for other social groups (Nadasdy 2003, Reisenweber 2008). Acts of effacement certainly characterize many historic and cultural preservation efforts in U.S. national parks, which have ignored the claims and histories of many indigenous peoples (Burnham 2000) and, elided the history of local rural whites (Ogden 2008b, 2011). Yet, more work needs to be done on how these processes of historical effacement operate in 
other kinds of conservation landscapes. My dissertation examines how Everglades ecosystem restoration and conservation efforts, and the landscape visions they create, have influenced arrangements of power and interpretive practice in a national preserve in the southern Everglades and reshaped the ways its complex social histories are conceptualized and revealed.

\section{Parks and Peoples Literature}

Recent scholarship demonstrates how national parks and nature preserves have reordered and re-imagined ecologically valuable landscapes and their histories. Through processes of land enclosure and a wilderness ideology such protected areas delineate a certain cultural politics of belonging and recognition, often at the expense of indigenous and rural people already living on those lands. These projects frequently create representational situations where ENGOs and states speak on behalf of local people and craft dominant landscape narratives that obfuscate local claims (West 2006). Moreover, anthropologists, geographers and environmental historians have shown how national parks and protected areas have displaced indigenous and rural dwellers and dismissed their cultural claims for the sake of creating nationally significant and uninhabited scenic and scientific wildernesses (Cronon 1995, Neumann 1998, Spence 1999, Li 2007, West, Igoe and Brockington 2006). There is no doubt that U.S. national parks have played a pivotal role in reconstructing and reinterpreting the history of many U.S. landscapes through a wilderness paradigm that legitimizes certain kinds of human presence (tourists, scientists, visitors) but excludes others (hunters, dwellers, poor whites) (Spence 1999). 
Yet, more work needs to be done on the exclusionary logics animating other kinds of conservation projects like ecosystem restoration initiatives. Addressing this gap, my work in the southern Everglades asks what kinds of exclusionary landscape visions and practices are created by Everglades restoration, and examines how ecological restoration efforts overlaid on already enclosed parklands raise new questions about the proper place for white outdoorsmen in the southern Everglades" "wilderness."

\section{Research Methods}

\section{Research Focus}

For the purposes of this study, I focused on two environmental conservation projects in the southern Everglades: 1) the ongoing efforts to steward and restore the Big Cypress National Preserve, and 2) the Tamiami Trail project at the northern boundary of Everglades National Park. The Tamiami Trail project is a component of the Modified Water Deliveries project (as discussed above), which is designed to elevate the Tamiami Trail highway (U.S. 41) in order to restore water flow to the now perpetually and artificially dry habitats of Everglades National Park. These two projects are high-profile Everglades conservation initiatives emblematic of the larger socio-political tensions that continue to complicate ecosystem protection and restoration efforts in the southern Everglades region. Both projects take place on National Park Service lands deemed ecologically significant by the larger ecosystem restoration and conservation communities. The Big Cypress National Preserve is a vital rain-driven watershed that feeds into Everglades National Park and is home to endangered species habitats, while the Tamiami Trail project is expected to rehydrate two ecologically important water 
bodies in Everglades National Park - Shark River Slough and Florida Bay - in order to restore a more natural and historically consistent hydrologic regime to the Park landscape. Both projects also pose important social justice questions: How will the water flows and environmental stewardship decisions associated with these restoration projects impact the place attachments and practices of peoples traditionally associated with the southern Everglades, including white outdoorsmen?

These projects allowed me to trace the evolution of conservation and ecosystem restoration ideas, and their associated forms of environmental governance and politics, in the context of a regional conservation initiative designed to protect and rehabilitate the southern Everglades. These two projects also enabled me to focus in on a time period for which a living history still existed. The Big Cypress National Preserve was created in 1974, while the Tamiami Trail project began in 1989 in concert with the expansion of Everglades National Park. Thus, outdoorsmen are still alive who have experienced these conservation and ecosystem restoration interventions firsthand.

\section{Research Overview, Duration and Research Sites}

My dissertation research entailed almost 16 months of multi-sited fieldwork and data collection in the southern Everglades and at other key locations. I drew upon multiple methods and data sources including archival research, ethnographic fieldwork, participant observation, semi-structured interviews and survey research to document the historic and contemporary human dimensions of environmental conservation in the southern Florida Everglades. I detail my use of these research methods below. Table 1 presents a complete overview of my research methods. 
Table 1: Research Methods Overview

\begin{tabular}{|c|c|c|}
\hline Research Question & Research Methods & Data Analysis \\
\hline $\begin{array}{l}\text { Q1. Environmental conservation's } \\
\text { effects on Everglades land } \\
\text { and water management } \\
\text { strategies; and ideas about } \\
\text { nature }\end{array}$ & 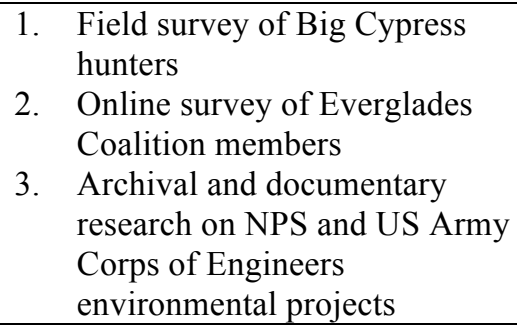 & $\begin{array}{l}\text { - } \text { Descriptive statistics } \\
\text { (Ragin 1994) } \\
\text { - Inductive (open) and deductive } \\
\text { coding } \\
\text { (Ryan and Bernard 2003, } \\
\text { Corbin and Strauss 2008) } \\
\text { - Analytic Notes } \\
\text { (Corbin and Strauss 2008 }\end{array}$ \\
\hline $\begin{array}{l}\text { Q2. The emergence and politics of } \\
\text { the "Gladesmen" identity }\end{array}$ & $\begin{array}{l}\text { 1. } 22 \text { interviews with self- } \\
\text { identified gladesmen and other } \\
\text { outdoorsmen } \\
\text { 2. } 7 \text { interviews with agency staff } \\
\text { 3. } 3 \text { interviews with ENGO staff } \\
\text { 4. Participant observation at } \\
\text { public meetings } \\
\text { 5. Archival and documentary } \\
\text { research on the Jetport } \\
\text { controversy and the creation of } \\
\text { the Big Cypress National } \\
\text { Preserve } \\
\text { 6. Documentary research on } \\
\text { Gladesmen Study } \\
\text { 7. Participant observation of } \\
\text { gladesmen practices and social } \\
\text { milieus. }\end{array}$ & $\begin{array}{l}\text { - Inductive (open) and deductive } \\
\text { coding } \\
\text { (Ryan and Bernard 2003, } \\
\text { Corbin and Strauss 2008) } \\
\text { - Constant comparison (Glaser } \\
\text { and Strauss 1967) } \\
\text { - Analytic Notes } \\
\text { (Corbin and Strauss 2008) } \\
\text { - Concept mapping } \\
\text { (Berg 2007) } \\
\text { - Timeline of key events } \\
\text { (Bernard 2006) }\end{array}$ \\
\hline $\begin{array}{l}\text { Q3. Evolving claims to place and } \\
\text { claims-making strategies by } \\
\text { the National Park Service, } \\
\text { ENGOs and local people. }\end{array}$ & 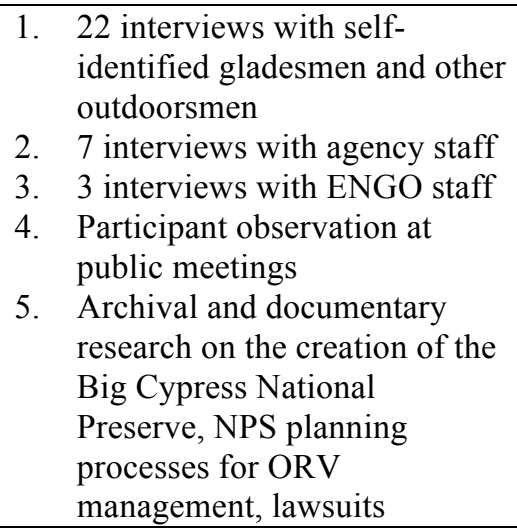 & $\begin{array}{l}\text { - Inductive (open) and deductive } \\
\text { coding } \\
\text { (Ryan and Bernard 2003, } \\
\text { Corbin and Strauss 2008) } \\
\text { - Constant comparison } \\
\text { (Glaser and Strauss 1967) } \\
\text { - Analytic Notes } \\
\text { (Corbin and Strauss 2008) } \\
\text { - Concept mapping } \\
\text { (Berg 2007 } \\
\text { - Timeline of key events } \\
\text { (Bernard 2006) }\end{array}$ \\
\hline
\end{tabular}

In the southern Everglades, I moved between a variety of social and political milieus associated with outdoorsmen's lives, Everglades ecosystem protection and restoration efforts and the performance of the Gladesmen culture including public meetings, backcountry trailheads and backcountry camps within the Big Cypress National Preserve and social gatherings of outdoorsmen at long-standing organizations 
like the Airboat Association of Florida. I also travelled to locations outside the southern Everglades to conduct research at archival collections and to conduct interviews with outdoorsmen.

\section{Research Strategies}

\section{Entrance Procedures and Subject Recruitment}

My entrance into the field was facilitated by two years of pilot research working with Everglades environmental NGOs, and informed by over five years of combined work experience on Everglades restoration-related policy issues with the South Florida Regional Planning Council and the NSF-funded Florida Coastal Everglades Longterm Ecological Research program (FCE-LTER) (Grant No. DEB-9910514). Specifically, I built up preliminary research contacts and data from 2008-2010 through pilot research and participant observation as a policy fellow for the National Parks Conservation Association (NPCA), a national environmental NGO that works on Everglades restoration and national park management issues in south Florida; and as a policy fellow for the Everglades Foundation, a local environmental NGO dedicated to advancing Everglades restoration.

Through these experiences, I made extensive contacts within the Everglades environmental NGO community, and I identified an initial group of informants from the Evergaldes outdoorsmen community: 1) an outdoorsmen who self-identified as a Gladesmen and was affiliated with the Airboat Association of Florida, as well as 2) a small group of commercial airboat operators along the Tamiami Trail roadway. These early stage field contacts, who I met by attending public meetings about the Tamiami 
Trail project in the East Everglades, helped me to gain an initial sense of the social and political landscape for white outdoorsmen in the southern Everglades, begin to understand the emergence of the Gladesmen culture, and meet additional research contacts. It was through conversations with these men that I identified the primary voices behind the contemporary movement for a Gladesmen culture, and realized that the Big Cypress Off-Road Vehicle Advisory Committee (an ongoing public advisory body to the Big Cypress National Preserve) was the venue where the politics of the Gladesmen culture were most prominently and publicly unfolding in the southern Everglades. Moreover, during my initial period of fieldwork, I made several preliminary visits to the South Florida Collections Management Center at Everglades National Park to conduct archival research on the history of airboat camps in the East Everglades. During my initial visits, I met an Everglades National Park employee who recounted his multigenerational family history in the Big Cypress region, and his misgivings about the Gladesmen culture and the ways it has come to dominant discussions about the human history of the southern Everglades. This chance encounter encouraged me to further focus my attention on the Big Cypress region as a compelling site of social complexity and Everglades identity politics. As a result of these experiences, I began to attend the Big Cypress National Preserve's Off-Road Vehicle Advisory Committee meetings where I was able to identify additional key informants and interviewees who represented the public face of the Gladesmen culture, and other white outdoorsmen's interest groups. In fact, I met and spoke with one outdoorsmen who heads a citizen group focused on maintaining ORV access in the Big Cypress National Preserve. It was through these interactions that I received invitations events that allowed me to immerse myself in the 
social milieus of outdoorsmen: the Airboat Association of Florida's $60^{\text {th }}$ Anniversary BBQ, and a large backcountry camp repair party following the 2011 Jarhead wildfire in the Big Cypress National Preserve and visits to several of the Big Cypress National Preserve backcountry camps I learned about in interviews. In this way, the ORVAC was a key research site . Over time, however, I realized that the ORVAC meetings represented and attracted more overtly political outdoorsmen who were more likely to be backcountry camp owners, and more likely to self-identify as members of the Gladesmen culture. I became curious about the perspectives and experiences of outdoorsmen outside this political arena, which is why I decided to conduct field surveys of outdoorsmen at trailheads in the Big Cypress National Preserve during the 2011 hunting season. I designed the field survey so that I could come into contact with and identify less overtly political outdoorsmen for my research. I used these field surveys to collect baseline data about the outdoorsmen who actively use the Big Cypress National Preserve but may not necessary be as engaged in political discussions about its management or Everglades protection. These field surveys enabled me to identify additional interviewees and informants outside of the ORVAC, and resulted in visits to a different subset of backcountry camps. By taking this research approach, I was able to capture the diversity and complexity of perspectives shared by Everglades outdoorsmen.

I now turn to the specific ways I used multiple research methods to systematically collect data to answer my research questions. 


\section{Ethnographic fieldwork}

I carried out ethnographic fieldwork with self-identified Gladesmen, and other white outdoorsmen to learn more about their social and historical ties to the Everglades. When invited, I accompanied Everglades outdoorsmen on foot, via airboats and on their swamp buggies to their backcountry camps, to favorite hunting spots and to sites significant to them in the backcountry of the Big Cypress National Preserve and the East Everglades (a name given to the 189,000 acres added to the northeast corner of Everglades National Park in 1989). These extended field trips, often coupled with focused interviews, allowed me to experience the Everglades through outdoorsmen's eyes and to record their stories. Our conversations in the Everglades provided vital insight into outdoorsmen's personal and historical ties to the Everglades and shed light on how these ties shape their contemporary practices, identities and perceptions of Everglades protection and restoration projects. I wanted to focus on outdoorsmen's narratives because their perspectives, knowledge and place attachments are often marginalized in the expert-driven, technoscientific context of contemporary Everglades restoration and management.

\section{Participant Observation}

In addition to spending time with Everglades outdoorsmen in the southern Everglades, I observed a number of public meetings and social gatherings related to offroad vehicle use and management in the Big Cypress National Preserve. I attended almost all of the Big Cypress National Preserve Off-Road Vehicle Advisory Committee (ORVAC) meetings held during my fieldwork. The ORVAC is an advisory body created 
by the National Park Service and tasked with making recommendations to the NPS on ORV trail implementation in the Big Cypress National Preserve. These meetings allowed me to observe the political and public dimensions of the contemporary Gladesmen identity and to learn more about outdoorsmen's land management perspectives. By participating in these meetings, coupled with my ethnographic fieldwork and field surveys, I was able to continuously interact with and be part of the ordinary and political lives of outdoorsmen in the Everglades, a hallmark of participant observation (Corbetta 2003, Bernard 2006). I used daily and weekly field notes to describe and interpret my interactions with the people and places I engaged with in the southern Everglades (Bernard 2006).

\section{Semi-structured Interviews}

I interviewed 32 Everglades outdoorsmen, environmental NGO staff and National Park Service staff to better understand contemporary tensions centered around questions of cultural authenticity, environmental stewardship, and the proper place for people in the southern Florida Everglades. Approximately 30-50 interviews are standard for ethnographic fieldwork in order to achieve data saturation (Morse 1994, Bernard 2006). My interviews were guided by thematic interview protocols (Bernard 2006). Specifically, I interviewed the Superintendents of Everglades National Park and Big Cypress National Preserve. I also spoke with and interviewed representatives of two national environmental NGOs who sit on the Big Cypress Off-Road Advisory Committee and are actively involved in stewardship debates about the Big Cypress National Preserve, as well as the 
leader of an ENGO that is very involved in the negotiations and lawsuits over ORV use in BICY.

\section{Survey Research}

I conducted two separate surveys as part of my dissertation research. I designed and implemented a field survey to capture the perspectives of hunters and ORV users on land management in the Big Cypress National Preserve $(n=38)$, and I executed an online survey ( $\mathrm{n}=91$ ) of environmentalists' attitudes towards Everglades restoration.

For my structured field survey, I randomly sampled outdoorsmen at three separate ORV trailheads in the Big Cypress National Preserve on three different dates during the fall 2011 deer hunting season. I asked hunters and ORV users questions about their use of the Big Cypress National Preserve, their hunting practices and their attitudes towards National Park Service management. As part of a separate Florida Coastal Everglades LTER research initiative called "Defining Everglades Restoration Success," I worked with my advisor, anthropologist Laura Ogden, and two senior Everglades scientists, John C. Ogden and Thomas Van Lent, to design and disseminate an online survey to Everglades environmentalists. The 2011 Everglades Coalition served as my sampling frame. The purpose of the survey was to elicit how this broader community of Everglades environmentalists valued the Everglades and envisioned its successful restoration.

Broadly speaking, the survey results demonstrated that Everglades environmentalists hold a hydrologically driven vision of Everglades restoration (I examine these results in detail in Chapter 2). 


\section{Archival Research}

I pursued archival research at the National Archives and Records Administration (College Park, MD) and at the South Florida Collections Management Center (Everglades National Park) to examine in greater depth the themes and events revealed by my fieldwork (Kosek 2006). While my research themes had a lived and political reality that unfolds in the Everglades landscape and at public meetings, they also had a documentary reality. I investigated their documentary reality through visits to two government archives and by reviewing a number of key management documents and scientific reports about both the Big Cypress National Preserve and the Tamiami Trail project. I spent approximately one week at the National Archives and Records Administration branch in College Park, Maryland (NARA II) examining official correspondence between high- level officials about National Preserve creation and its early management. I spent another two weeks at the Everglades National Park Archives researching the history and founding of the Big Cypress National Preserve as well as collecting information about how the National Park Service chose to manage the numerous backcountry camps and private properties that dotted the newly designated National Preserve landscape. At the ENP archives, I located a rich body of correspondence between local people who had constructed backcountry camps in cypress country and the National Park Service as well as a large collection of photos cataloguing the different backcountry camps on National Preserve lands.

Many of the outdoorsmen (and the women in their lives) who I interviewed were also rich sources of oral history and archival materials. They provided me with old photographs, magazine articles, newspaper clippings and personal accounts of swamp life 
in the Big Cypress country before National Preserve creation and about the National Preserve's effects on their lives. I was often impressed by their interest in and large collection of newspaper articles about NPS management. Several shared stunning scrapbooks portraying the history of their backcountry camps and their Everglades adventures. One of my favorite scrapbooks detailed its owner's participation in swamp buggy races in Naples, Florida at a time when these races were a focal point of entertainment for the community - where a swamp king and a swamp queen were crowned annually. This scrapbook was material evidence of a time when Florida's coastal cities were more culturally and physically connected to the fabric of the Everglades.

\section{Research Populations}

As I indicated above, I chose to focus my field research on outdoorsmen and their experiences in, perspectives on, and place attachments to the southern Everglades. Outdoorsmen's views are rarely discussed in the main body of official NPS management documents or scientific reports, even when they may have important insights to offer about the environmental history of the Everglades. Outdoorsmen's voices are typically relegated to the appendices of official documents - where they appear in appended comment letters - or to the three-minute public comment period allowed during public meetings. While outdoorsmen's opinions are captured in some newspaper and magazine articles about the management of national park units and hunting in the southern Everglades, these printed pieces do not provide in-depth insight into their life histories, positions on NPS land management or place attachments. 
Most of the outdoorsmen I spent time with were native Floridians - many from the Miami area - although some had relocated to live in other states. A smaller number were from Florida's west coast and from rural towns throughout south Florida including Homestead, La Belle, Arcadia, Parrish and Venus. Most of the outdoorsmen I spoke with were white men over the age of 40 who had spent, on average, at least twenty years of their adult life navigating the lands, waters and forests of the southern Everglades. Most were seasoned outdoorsmen who spend, on average, at least two-three weeks each year in the southern Everglades.

Many of the outdoorsmen I interviewed are politically active in the off-road vehicle (ORV) access and resource management issues that affect the East Everglades and the Big Cypress National Preserve. Many are also backcountry camp owners in the Big Cypress National Preserve. Most of the outdoorsmen I spoke with have lived through and directly observed tremendous changes to the Everglades landscape from drainage and development. As such, they are rich sources for learning more about Everglades environmental history. Moreover, most of these men were in their late teens or early $20 \mathrm{~s}$ when the Big Cypress National Preserve was created, and have lived through a large part of BICY's history as well as the inception of the Comprehensive Everglades Restoration Plan.

As I outlined above, I also interviewed a handful of apolitical outdoorsmen who do not own backcountry camps and do not participate in public meetings to be sure that my study data captured multiple perspectives. As anthropologists have observed, most communities of people are fragmented and diverse in environmental struggles (Agrawal and Gibson 1999). I wanted to ensure my research included the multiple voices present in 
the outdoorsmen community, and attended to their experiences both inside and outside of formal political meeting spaces. I met and spoke with many of the less overtly political outdoorsmen during my structured field surveys of ORV users and hunters, which I conducted at three ORV trailheads in the Big Cypress National Preserve during the fall 2011 deer hunting season (November and December 2011). To understand alternative rural white identities other than Gladesmen (negative cases), I also sought out outdoorsmen for interviews who have multi-generational ties to the southern Everglades but instead self-identify as "Florida crackers" (Ste. Claire 1998) - a less overtly political but equally powerful way of signifying longstanding cultural claims to the southern Everglades.

There are women in cypress country. Some of these women too own swamp buggies, hunt and frequent backcountry camps in the southern Everglades. However, I was not able to learn much about women's experiences during my fieldwork. I interacted with one politically active outdoorswomen who helped me to make contacts with selfidentified Gladesmen; however, she was not willing to sit down for a formal interview. There is a critical need for more research on women's experiences in the Big Cypress region past and present. I sincerely hope another scholar will take on this task. While I never felt ill at ease as a woman in cypress country, I am sure my gender, and my social positionality did shape some aspects of outdoorsmen's lives and practices that I saw, and the stories I was told. 


\section{A Note on Anonymity}

While I do use the real names of my research settings, I do not reveal the names of my interviewees and informants, except where they have given me direct permission to do so, or are public figures speaking in a public context. Instead, I refer to the people I spoke with using pseudonyms and I change their identifying details to ensure their anonymity.

\section{Overview of Chapters}

This dissertation includes six chapters and a conclusion. In chapter 1, I examine how two sometimes contradictory visions for Everglades improvement - 1) a developmentalist vision and 2) a protectionist vision -- have resulted in a succession of improvement schemes that have reshaped the Everglades across history (Li 2007). It describes these different improvement projects and examines how they have produced specific political ecologies (power-laden assemblages of people and nature). I argue that

the topography of power has shifted with each Everglades improvement scheme, whereby certain actors have emerged as Everglades trustees - those who possess the expertise, power or capital that gives them the ability to shape the lives of human and nonhuman others - while other actors have been relegated to the margins.

Chapter 2 contextualizes the roles and positions of Everglades environmental NGOs (ENGOs) and ENGO claims within the wider field of environmental actors and environmental conflict in the Florida Everglades. The chapter shows how the emergence of ENGOs as Everglades trustees is historically constituted and how ENGO claims are shaped by hydropolitics - the way in which water as a form of social and moral capital 
enables and constrains, but also unifies and divides Everglades ENGOs in their quest to protect the Everglades and advance Everglades restoration.

Chapters 3, 4 and 5 address the politics of place in the southern Everglades, and how these have been reshaped to the detriment of local values as the Everglades has become an iconic conservation and restoration landscape. Chapter 3 examines the unique political-ecological context of Big Cypress country prior to National Preserve creation and how it created a hunter's landscape - a unique way of being in the Everglades defined by particular practices, social relations and landscape meanings. Chapter 3 also outlines the deep and intimate place attachments of many outdoorsmen to the cypress country, showing how a part of their lives is rooted in this ecology. Chapter 4 explores how the creation of the Big Cypress National Preserve changed the cypress country into a different kind of place - a publicly-owned national park unit and conservation landscape defined by new bureaucratic and environmentalists optics and logics. Chapter 5 examines how the US Army Corps of Engineers, the federal sponsor of the Comprehensive Everglades Restoration Plan, has effaced the claims of local people and the sociohistorical character of Everglades nature from its planning efforts for the Modified Water Delivery project. Through an in-depth analysis of three engineering schematics, I show how outdoorsmen's and indigenous people's sociohistorical claims to the southern Everglades are discursively deleted as the Corps seeks to redefine the Everglades as a series of discrete water features amenable to hydrologic engineering.

Chapter 6 shows how the changing politics of place in the Everglades have provoked counter-claims by those denied positions of environmental trusteeship. I detail the rise of an oppositional white identity, the Gladesmen Culture, as a response to the 
ways outdoorsmen and their practices have been marginalized in the material and symbolic spaces of the southern Everglades (as described in Chapters 3-5). I argue that white outdoorsmen invoke the Gladesmen Culture as a political tool and strategy of authenticity in order to re-establish the visibility of their particular kind of sociohistorical whiteness in an Everglades remade by environmentalist and technoscientific discourses of conservation, wilderness and national park protection; and to garner greater recognition as a people who belong in the Everglades. Ultimately, Chapter 6 demonstrates how conflicts over nature can produce new cultural heritage claims and novel identities aimed at reterritorializing displaced practices and marginalized human histories. In the conclusion, I summarize the main points of my dissertation, and discuss my dissertation's key research findings. 


\section{REFERENCES}

Agrawal, Arun

2005 Environmentality. Durham, NC: Duke University Press.

Agrawal, Arun and C. C. Gibson

1999 Enchantment and Disenchantment: The of Community in Natural Resource

Conservation. World Development 27(4): 629-649.

Basso, Keith

1996 Wisdom Sits in Places: Language and Landscape among the Western Apache. Albuquerque: University of New Mexico Press.

Berg, Bruce

2007 Qualitative Research Methods for the Social Sciences. $6^{\text {th }}$ ed. New York Pearson.

Bernard, H. Russell

2006 Research Methods in Anthropology. $4^{\text {th }}$ ed. New York: AltaMira Press.

Biersack, Aletta

2006 Reimagining Political Ecology: Culture/Power/History/Nature. In Reimagining Political Ecology. Aletta Biersack and James B. Greenberg, eds. Pp. 3-42. Durham, N.C.: Duke University Press.

Braun, Bruce

2002 The intemperate rainforest : nature, culture, and power on Canada's west coast.

Minneapolis: University of Minnesota Press.

Brosius, J. Peter

1999 "Green Dots, Pink Hearts, Displacing Politics from the Malaysian Rain Forest." American Anthropologist 101.

Bryant, Raymond L. and Sinéad Bailey. 1997 Third World Political Ecology. London: Routledge.

Buffalo Tiger and Harry A. Kersey Jr.

2002 Buffalo Tiger: A Life in the Everglades. Lincoln, NB: University of Nebraska Press.

Burnham, Philip.

2000 Indian country, God's country : Native Americans and the national parks.

Washington, DC: Island Press. 
Carrier, James and Paige West, eds.

2004 Virtualism, Governance and Practice: Vision and Practice in Environmental

Conservation. New York: Berghahn Books.

Casey, Edward

1996 How to Get from Space to Place in a Fairly Short Stretch of Time:

Phenomenological Prolegomena. In Senses of Place. Steven Feld and Keith Basso, eds. Pp. 13-52. Santa Fe, NM: School of American Research Press.

Cattelino, Jessica.

2008 High Stakes: Florida Seminole Gaming and Sovereignty. Durham, NC: Duke University Press.

2009 Florida Seminoles and the Cultural Politics of the Everglades. Occasional Paper from the School of Social Science, Institute for Advanced Study. May: Paper Number 36

Clarke, Alice and George Dalrymple

2003 \$7.8 Billion for Everglades Restoration: Why Do Environmentalists Look So

Worried? Population and Environment 24(6): 541-569.

Corbetta, Piergiorgio

2003 Social Research: Theory, Methods and Techniques. Thousand Oaks, CA: Sage.

Corbin J. and A. Strauss

2008 Basics of qualitative research: Techniques and procedures for developing grounded theory. Thousand Oaks, CA: Sage.

Cronon, William

1995 The Trouble with Wilderness; or, Getting Back to the Wrong Nature. In Uncommon Ground: Rethinking the Human Place in Nature. William Cronon ed. Pp. 69-90. New York: W. W. Norton \& Co.

Daniels, Stephen and Denis Cosgrove

1988 Introduction: Iconography and Landscape. In The Iconography of Landscape:

Essays on the Symbolic Representation, Design and Use of Past Environments. Denis Cosgrove and Stephen Daniels eds. Cambridge: University of Cambridge Press.

DeLanda, Manuel

2006 A New Philosophy of Society: Assemblage Theory and Social Complexity. New York: Continuum.

Deleuze, Gilles and Felix Guattari

1987 A Thousand Plateaus. Minneapolis, MN: University of Minnesota Press. 
Derr, Mark

1998 Some Kind of Paradise: A Chronicle of Man and the Land in Florida.

Gainesville, FL: University Press of Florida.

Doyle, Mary

2008 "The Everglades." In Large-scale Ecosystem Restoration: Five case studies from the United States. Mary Doyle and Cynthia Drew, eds. Pp. 1-2. Washington, DC: Island Press.

Escobar, Arturo

2008 Territories of Difference: Place, Movements, Life, Redes. Durham, NC: Duke University Press.

Feld, Steven and Keith Basso

1996 Introduction. In Senses of Place. Steven Feld and Keith Basso eds. Pp. 3-12. Santa Fe, NM: School of American Research Press.

Foucault, Michel

1977 Nietzche, geneaology, history. Trans. Donald F. Bouchard and Sherry Simon. In Language, Counter-Memory, Practice: Selected Essays and Interviews. Donald F. Bouchard, ed. Ithaca, NY: Cornell University Press.

2000[1994] Governmentality. In Power: The Essential Works of Foucault: 1954-1984. James D. Faubion, ed. New York: The New Press.

Glaser, B. and A. Strauss

1967 The Discovery of Grounded Theory: Strategies for Qualitative Research. New York: Aldine.

U.S. Government Accountability Office (U.S. GAO)

2007 South Florida Ecosystem Restoration Is Moving Forward but Is Facing Significant Delays, Implementation Challenges, and Rising Costs. Report for House Committee on Transportation and Infrastructure. Washington, DC: GPO. GAO-07520

Grunwald, Michael

2006 The Swamp: The Everglades, Florida, and the Politics of Paradise. New York:

Simon and Schuster.

Gupta, Akhil and James Ferguson

1997 Beyond Culture: Space, Identity and the Politics of Difference. In Culture, Power, Place: Explorations in Critical Anthropology, Akhil Gupta and James Ferguson eds., Pp. 33-51. Durham, NC: Duke University Press. 
Haenn, Nora

2005 Fields of Power, Forests of Discontent: Culture, Conservation and the State in Mexico. Tucson: University of Arizona Press.

Haraway, Donna

2008 When Species Meet. Minneapolis, MN: University of Minnesota Press.

Harvey, David

1996 Justice, Nature and the Geography of Difference. Wiley-Blackwell.

Heatherington, Tracey

2010 Wild Sardinia: Indigeneity and the Global Dreamtimes of Environmentalism. Seattle, WA: University of Washington.

Higgs, Eric

2003 Nature by Design. Cambridge, MA: MIT Press.

Hollander, Gail M.

2008 Raising Cane in the 'Glades: The Global Sugar Trade and the Transformation of Florida. Chicago: The University of Chicago Press.

Igoe, Jim.

2004 Conservation and Globalization : a Study of National Parks and Indigenous Communities from East Africa to South Dakota. Case Studies on Contemporary Social Issues. Belmont, CA: Thomson/Wadsworth.

Keller Robert and Michael Turek

1998 American Indians and National Parks. Tucson: University of Arizona Press.

Kersey Jr., Harry A.

1975 Pelts, Plumes and Hides: White Traders Among the Seminole Indians, 1870-

1930. Gainesville: University of Florida Presses.

Kosek, Jake 2006 Understories: The Political Life of Forests in New Mexico. Durham, NC: Duke University Press

Li, Tanya

2007 The Will to Improve. Durham, NC: Duke University Press.

Light, Alfred

2006 Tales of the Tamiami Trail: Implementing Adaptive Management in Everglades

Restoration. Journal of Land Use 22(1): 59-99. 
Matthews, Andrew

2011 Instituting Nature: Authority, Expertise and Power in Mexican Forests.

Cambridge, MA: The MIT Press.

Mitchell, W.T.

2002 Landscape and Power. $2^{\text {nd }}$ ed. Chicago: University of Chicago Press.

Moore, Donald

2005 Suffering for Territory: Race, Place and Power in Zimbabwe. Durham, NC: Duke University Press.

Morse, Janice

1994 Designing funded qualitative research. In Handbook for qualitative research, N.

Denzin and Y. Lincoln eds., Pp. 220-35. Thousand Oaks, CA: Sage.

Nadasdy, Paul.

2003 Hunters and Bureaucrats. Toronto: UBC Press.

(NAS) Committee on Independent Scientific Review of Everglades Restoration Progress, National Research Council, National Academy of Sciences

2008 Progress toward restoring the Everglades: The second biennial review. Washington, DC: National Academies Press.

2010 Progress toward restoring the Everglades: The third biennial review. Washington, DC: National Academies Press.

2012 Progress toward restoring the Everglades: The fourth biennial review.

Washington, DC: National Academies Press.

Neumann, Roderick P.

2005 Making Political Ecology. New York: Oxford University Press.

1998 Imposing Wilderness. Berkeley, CA: University of California Press.

Ogden, Laura

2008a The Everglades Ecosystem and the Politics of Nature. American Anthropologist 110(1): 21-32.

2008b Searching for Paradise in the Florida Everglades. Cultural Geographies 15: 207-229.

2011 Swamplife: People, Gators and Mangroves Entangled in the Everglades.

Minneapolis: University of Minnesota Press.

Olwig, Kenneth

2002 Landscape, nature, and the body politic : from Britain's renaissance to America's new world. Madison: University of Wisconsin Press. 
Peet, Richard and Michael Watts

2004 Liberating Political Ecology. In Liberation Ecologies. $2^{\text {nd }}$ ed. Richard Peet and Michael Watts, eds. Pp. 3-47. New York: Routledge.

Raffles, Hugh

1999 In Amazonia: A Natural History. Princeton, NJ: Princeton University Press.

Ragin, Charles

1994 Constructing Social Research: The Unity and Diversity of Method. Thousand Oaks, CA: Pine Forge Press.

Riesenweber, Julie 2008 Landscape Preservation and Cultural Geography. In Cultural Landscapes, Richard Longstreth, ed., Pp. 23-34. Minneapolis: University of Minnesota Press.

Robbins, Paul

2004 Political Ecology. Malden, MA: Blackwell Publishing.

Ryan, Gery and H. Russell Bernard

2003 Techniques to Identify Themes. Field Methods 15(1):85-109.

Spence, Mark David

1999 Dispossessing the wilderness: Indian removal and the making of the national parks. New York: Oxford University Press.

Ste. Claire, Dana

1998 Cracker: The Cracker Culture in Florida History. Daytona Beach, FL: The Museum of Arts and Sciences.

Strang, Veronica

2003 Moon Shadows: Aboriginal and European Heroes in an Australian Landscape. Pamela Stuart and Andrew Strathern, eds. Pp. 108-135. Sterling, VA: Pluto Press.

Tebeau, Charlton

1968 Man in the Everglades: 2000 Years of Human History in the Everglades National Park. $2^{\text {nd }}$ ed. University of Miami Press.

Tsing, Ana

2005 Friction: An Ethnography of Global Connection. Princeton: Princeton University Press.

Walley, Christine

2004 Rough Waters: Nature and Development in an African Marine Park. Princeton: Princeton University Press. 
West, Paige

2006 Conservation is Our Government Now. Durham, NC: Duke University Press.

West, Paige, Jim Igoe and Dan Brockington

2006 Parks and Peoples: The Social Effects of Protected Areas. Annual Review of Anthropology 20 (3): 609-616.

West, Patsy

1998 The Enduring Seminoles: From Alligator Wrestling to Ecotourism. University Press of Florida.

Wiedman, Dennis

2010 Global Marketing of Indigenous Culture: Discovering Native America with Lee Tiger and the Florida Miccosukee." American Indian Culture and Research Journal 34 (3): $1-26$.

Wylie, John

2009 Landscape, Absence and the Geographies of Love. Transactions of the Institute of British Geographers 34: 275-289.

Yung, Laurie, Wayne A. Freimund and Belsky, Jill M.

2003 The Politics of Place: Understanding Meaning, Common Ground and Political Differences on the Rocky Mountain Front. Forest Science 46(6):855-866. 


\section{Chapter 1: Political Ecologies of Progress - The Will to Improve and Shifting Environmental Politics in the Florida Everglades}

\section{Introduction}

The history of the Everglades (and south Florida) is one of transformation. The Everglades has been remade time and time again in the name of progress and improvement (Tebeau 1977, Derr 1998, McCally 1999, Hollander 2008, Grunwald 2006). Different actors, ranging from early land barons, state officials and reclamation engineers to contemporary environmentalists and government agencies, have put forward visions of progress and rallied behind improvement projects designed to render this landscape more profitable, more habitable, more attractive to tourists or more ecologically resilient. These visions for improving south Florida and their resultant projects have powerfully reshaped the region's lands and waters, peoples, and environmental politics.

In this chapter, borrowing a term from Tanya Li’s (2007) analysis of environment and development projects, I examine the two sometimes contradictory "wills to improve," or motivations for improvement, that have most significantly reshaped the Everglades across history. I divide these wills into two broad categories:

developmentalist and protectionist. I trace how the interplay (or push and pull) between these two wills to improve has produced the seemingly bifurcated South Florida we know today: part iconic conservation landscape on the peninsula's interior, part Sunbelt suburban sprawl and glitzy cosmopolitan playground for the world's wealthiest elites on the peninsula's coasts. I show how, together, these two motivations have given rise to a succession of environmental conservation and development projects (albeit with different 
goals and outcomes) ranging from extensive wetland reclamation to national park creation to widespread suburban development to the inception of one of the world's largest ecosystem restoration projects. I describe these different improvement projects and examine how they have produced specific political ecologies, or landscape assemblages, changing the material landscape as well as the social relations surrounding the management and transformation of nature ${ }^{1}$. With each improvement scheme, certain actors have emerged as Everglades trustees ${ }^{2}$ - those who possess the expertise, power or capital that gives them the ability to shape the lives of human and nonhuman others, while other actors have been relegated to the margins. Specifically, I show how programs of improvement in the Everglades have shared an ambivalence towards the lifeways and livelihoods of indigenous peoples, and glades people of all walks of life (communities that don't fit into their utopian imaginaries of progress), excluding and effacing the territorial claims and territorial histories of these local peoples. In this way, I demonstrate how Everglades improvement projects are premised on asymmetrical power relations, and how those in the position of Everglades trusteeship, who preside or have presided over its improvement projects, have more power to shift and transform the Everglades assemblage, including the people/place relationships of others. Yet, in this and future chapters, I explore how the space of alterity/marginality produced by Everglades

\footnotetext{
${ }^{1}$ I conceptualize south Florida as a socio-ecological system where the seemingly separate urbanized coasts and the interior wildlands are in fact intimately interconnected through historical process, ecology and future regional trajectories.

${ }^{2}$ When I use the term trustee, I use it in a particular theoretical way, following the work of Tanya Li (2007). Li underlines that improvement programs typically are designed and implemented by actors in a position of trusteeship, or a position of power. Yet, $\mathrm{Li}$ (2007) explains, only certain actors are able to occupy the position of trustee. Actors like multi-lateral development agencies, states and ENGOs can make the claim that they possess the expert knowledge and resources necessary to enhance a population or environment - a position that grants them the ability to design development projects and intervene in the lives of others.
} 
improvement projects has facilitated a politics of reterritorialization, where new kinds of environmental subjectivities and environmental claims emerge to reclaim land and landscape.

I draw upon the development literature, ethnographies of conservation and political ecology scholarship to frame my discussion of the political-ecological trajectory of the Everglades landscape. First, I document how a developmentalist will to improve, focused on transforming the waterlogged and miasmic Everglades into a productive "agricultural cornucopia" (McCally 1999, Hollander 2008), was the dominant attitude towards nature following Florida statehood. I assert that this "will to improve," premised on the human domination of nature, prompted a succession of Everglades drainage projects, but also sparked questions about the environmental consequences of progress. Thus, a protectionist will to improve, which sought to safeguard Everglades nature from over-exploitation, was born out of the early developmentalist push for the widespread reclamation of the Everglades. Concerned white scientists and concerned citizens (then men and women from the elite classes) lobbied to protect a slice of the Everglades from human intervention, prompting the designation of Royal Palm Hammock State Park in 1916 and the authorization of Everglades National Park in 1934. This era culminated in two key projects in 1947, which would shape south Florida's future: the creation of Everglades National Park, driven by protectionist interests, and the Central and Southern Florida flood control project, driven by developmentalist interests.

I then trace how, with the implementation of the Central and Southern Florida Project ("CS\&F project") and other post-WWII large-scale infrastructure projects, the developmentalist impulse once again took hold, although in a different form. Real estate 
developers aimed to remake south Florida into a Sunbelt paradise designed to attract homebuyers from across the United States. Land developers promoted the transformation of nature into homes (not farms) and sparked a wave of widespread suburbanization and real estate speculation. Yet again, there was pushback against this developmentalist will to improve. Questioning the dominant narrative of growth as the harbinger of prosperity and progress, environmental advocates, hunters and concerned citizens lobbied against the construction of a megalithic airport in the Big Cypress Swamp. Through the struggle between conservation and development, the Big Cypress National Preserve, a protected multi-use landscape in the National Park system, was created. Finally, I examine the contemporary Everglades restoration project, arguing that it too must be situated within the arc of improvement projects that has characterized south Florida's history. While designed to remedy decades of environmental degradation caused by the Central and Southern Florida flood control project, I assert that Everglades restoration emerges at the confluence of the protectionist and the developmentalist wills to improve. Certain trustees vie to make it into a water supply project while others focus on ensuring it remains an ecological restoration project.

In summary, chapter 1 maps out what Goldman and Turner (2011) term "the heterogeneous and power-laden processes" bound up with south Florida's many improvement projects, which have shaped its political ecologies and its environmental politics. Thus, the present chapter will: 1) set the stage for understanding the historical antecedents of contemporary struggles over the protection, management and restoration of the southern Everglades by tracing how human and nonhuman positionings and entanglements have come into being in the contemporary Everglades assemblage, and 2) 
contextualize how Everglades improvement projects are part of the process through which the openings and closings of power operate in struggles for discursive and material control over the Everglades. These shifts in the topography of power over time and space, whereby environmental trustees and environmental subjectivities emerge or are challenged in the Everglades assemblage, are what I term the environmental politics of progress in the Florida Everglades.

\section{Literature Overview}

A large body of literature exists, which examines and critiques the practice of development. Generally development projects are initiated as a reaction to the perceived underdevelopment of a particular part of the world, and prescribe technical solutions to remedies those deficiencies. Initially, development was structured around a constructed divide between Western countries and the rest of the world, where non-Western countries were viewed as nations in need of assistance from Western experts so that they could modernize. Development is premised on the belief that expert technical interventions in forms such as engineering, economic policy, biomedicine and biology can transform people and places into more productive, modern and prosperous forms (Escobar 1995, Mitchell 2002).

Development reflects a faith that human ingenuity can overcome any obstacles to progress, including uncooperative nature. In this equation, nature usually factors in as a force "to be overcome or material resources to be developed" (Mitchell 2002, 51). Some of the best examples of the developmentalist stance toward nature are the big dam projects, the $20^{\text {th }}$ century's largest construction projects (Mitchell 2002, 21). These 
projects dot the globe and range from the Hoover Dam in Colorado, to the Aswan Dam in Egypt. They are massive and impressive public works that reconfigure the very idea of "a river," epitomize the unwavering modernist faith in engineering's ability to dominate nature and "are unique in the scope and manner in which they alter the distribution of resources across space and time, among entire communities and ecosystems" (Mitchell 2002, 21; see also Reisner 1993).

Yet, development projects have to contend with the complexity and messiness of the world. One of the practices required of all development (and more generally, improvement) projects is to translate varied and complex social realities onto paper in ways that "require precisely those [technical solutions], which development agencies are setup to provide" (Ferguson 1994, 70). As Li explains, this requires "translating messy conjunctures into...linear narratives or problems, interventions and beneficial results." As many scholars have shown, this process of turning complicated cultural and political realities into clean-cut blueprints for a better future, which are amenable to technical solutions, necessitates exclusion and erasure. In this way, in the quest for progress, certain communities or facts that do not fit into these visions are marginalized during the design of development projects. Thus, development projects typically efface some combination of local territorial claims, local histories and local particularities. Yet, as $\mathrm{Li}$ notes, the practice of exclusion "is itself an intervention with far-reaching effects" (8).

While development scholars have attended to the discourse of development and how its documentary practices remake the world through processes of abstraction and exclusion, political ecologists are concerned with the material and discursive dimensions of environmental struggle (in grounding development in the material world) They are 
interested in navigating what Michael Herzfeld (2001) has termed "the Militant Middle Ground" between materialism and idealism. They examine how discursive constructions of nature (the way nature is imagined, valued) are central to the transformation of nature (the way nature is materially managed and used), linking these two domains and paying explicit attention to how power operates within them. Political ecology has called attention to the ways power asymmetries shape the material and social outcomes of environmental struggles and figure social difference. Thus, political ecological scholarship is important for understanding the links between power-laden environmental struggles (politics) and the production of environmental subjectivities.

In recent years, anthropologists have devoted increasing scholarly attention to understanding how development discourses intersect with environmental projects to remake landscapes and local peoples in new ways. In particular, anthropologists have analyzed numerous integrated conservation and development projects (ICDPs), which are improvement projects that strive to achieve the twin goals of biodiversity conservation and the augmentation of local people's well being (usually through projects that seek to increase local incomes and infrastructure systems). In her ethnography of an ICDP focused on and around Lore Lindu National Park in Indonesia, Tanya Li broadens out the traditional definition of development projects to the more general category of improvement projects, which, she asserts, have the more expansive goal of enhancing "the condition of a population [or environment] in a deliberate manner" (1). Li describes how improvement projects do not arise sui generis but are motivated by the "will to improve." As she explains, improvement projects are part of the constellation of power Foucault termed "governmentality," and "the will to improve" is the rationale guiding 
development interventions. The will to improve defines what needs to be changed (circumscribes the problem), how and why changes should be made (presents a clear-cut vision for the future) and what technical calculations are required to resolve the problem at-hand. Importantly, Li defines the position of power in development projects as "trusteeship" and describes how trusteeship works. She underlines that improvement programs typically are designed and implemented by actors in a position of trusteeship who invoke the will to improve. Yet, $\mathrm{Li}$ (2007) explains, only certain actors are able to occupy the position of trustee. Actors like multi-lateral development agencies, states and ENGOs can make the claim that they possess the expert knowledge and resources necessary to enhance a population or environment - a position that grants them the ability to design development projects and intervene in the lives of others. While not necessarily ill intentioned, Li explains that the will to improve often has adverse and uneven social and environmental effects as it remakes landscapes, identities, livelihoods and ideas about the management of nature (Scott 1998, West 2006, Li 2007). Yet, Li argues that the will to improve (the practice of government) is not a closed, totalizing or static system but opens up opportunities for contestation (Li 2007). As Li writes (2007, 12): "the practice of politics - the expression, in word or deed, of a critical challenge....opens up a front of struggle" through which trusteeship is challenged. I argue that it is through this space of challenge and contestation that Everglades improvement projects create opportunities for emergent processes of environmental subject-formation and environmental claims-making. As James Scott (1998) has observed in his seminal book Seeing Like a State, the objects and people excluded by development projects don't disappear; they often re-emerge from the margins to contest and complicate future 
development interventions. Thus, improvement projects are part of the process through which the openings and closings of power operate in Everglades environmental struggle.

\section{The Developmentalist Will to Improve: A More Productive Everglades}

The Everglades is a place where human ingenuity has been applied time and time again since the 1800 s to try and transform this watery landscape into a more productive place, often with unintended consequences. These developmentalist impulses to "improve" south Florida have stemmed, in part, from reactions to the material nature of the Everglades as a wetland ecosystem. As Ann Vileisis (1997) has observed, "[throughout history] wetlands figured prominently into the American dream - not as they were, but as what they might become." The Everglades was no different. After Florida became the 27th American state in 1845, wealthy northern capitalists and state boosters viewed the Everglades through an "opportunistic" lens (Ogden 2011). They saw it as a miasmic wetland in need of reclamation and development, and they were convinced that the region's abundant sunshine and subtropical climate held tremendous agricultural potential. Thus began the era of early Everglades drainage and transformation, driven by utopian visions of remaking the interior Everglades into a "wildly productive agricultural cornucopia" (McCally 1999).

Hamilton Disston, a wealthy northern capitalist and one of Florida's first land speculators, had the first large-scale vision for improving the Everglades, and the capital to execute it. Disston focused his efforts on transforming the Everglades from a dismal swamp into sugar plantations and prosperous farming communities (Hollander 2008). In 1881, Disston purchased 4 million acres of swampland from the State of Florida in one 
fell swoop (McCally 1999), becoming an Everglades trustee through the sheer size of his landholdings. As a result of his land purchase, Disston effectively owned almost one-half of Florida: an enormous triangle-shaped territory that stretched across south Florida from Marco Island to Tampa Bay to Titusville and back (Derr 1998). Disston "promised to drain all of the swamps overflowed by Lake Okeechobee and the Kissimmee River in exchange for one-half of the reclaimed land" (Vileisis 1997, 135). As one of the poorest and most sparsely populated southern states at the turn of the twentieth century (Hollander 2008), Florida state officials were eager to accept his investment.

Disston constructed one of the first public works in the Everglades: a linchpin canal to drain Lake Okeechobee through the Caloosahatchee River (Vileisis 1997), igniting a faith in the idea that Everglades drainage was possible and beginning the Everglades' transition into an amalgam of human management, nature and technology. Yet, Disston's drainage plans did not succeed at the scale he envisioned. The biogeophysical complexity of the Everglades, which was not well understood at the time, thwarted his efforts and would complicate successive drainage projects attempted by the State of Florida (Blake 1980, Hollander 2008).

In the wake of Disston's project, the State of Florida was next to try its hand at draining the Everglades, effectively inserting itself into the role of Everglades trustee. Napoleon Bonaparte Broward, a Democratic and Progressive governor, believed in the productive potential of the Everglades. In 1905, he took up Everglades drainage as an engine for state economic development, incorporating it into the Progressive political platform for a better Florida. Broward thought Everglades' drainage would attract widespread settlement and create a tropical garden paradise where the independent man 
could make a prosperous living on a small plot of land. Broward was also a vocal sugar production booster, pronouncing that the Everglades' reclaimed land could "meet all of the nation's sugar needs" (Vileisis 1997, 137). Using the proceeds from large land sales, Broward proposed to drain six million acres of Everglades swampland using a canal system consisting of five drainage canals from Lake Okeechobee to the Atlantic coast, including the Miami River, New River and St. Lucie canals.

However, Everglades hydrogeology again proved much more complex than Broward could have anticipated, making difficult the implementation of his canal system and leaving eager homesteaders without dry ground. Despite Broward's missteps, the State of Florida remained fiercely committed to the idea of progress via drainage, and it hired a team of reputable engineers to chart a more viable drainage solution going forward (a report that would come to be known as the Randolph Report). Engineering became the handmaiden of the State of Florida, which used this expert knowledge to bolster state authority and popular confidence in drainage, as capitalist land development and state-funded infrastructure became locked in an ever-tighter embrace.

Governor Park Trammel focused state efforts on finishing the St. Lucie canal, which was designed to drain excess water from Lake Okeechobee into the Atlantic Ocean and prevent its overflow, and on deepening the existing canal system as recommended by government-contracted engineers in the Randolph Report.

At this juncture in Everglades history, transformation of the Everglades was difficult and expensive. Each state engineering intervention during this period seemed to require additional engineering to counter unanticipated consequences as nature set hurdles to drainage. As a result, every project seemed more costly and involved than 
estimated. For example, the canals the State of Florida dug to the Atlantic Ocean began to flow backwards into Lake Okeechobee during times of drought. Control structures were required to regulate the canal flows. Engineers constructed a system of thirteen locks and dams in these canals between 1913 and 1927 at a total cost of nearly 2 million dollars (McCally 1999, 132). Soil subsidence along the southern shore of Lake Okeechobee negated the flood control benefits expected from lowering the lake level through the St. Lucie Canal. In 1921, the State of Florida was forced to start construction of a dike from Moore Haven to Ritta to try and protect southern lakeside communities from floodwaters. In total, these projects were more than the State of Florida's Everglades Drainage District could reasonably fund. By 1927 , the District was more than $\$ 17$ million in debt.

The heavy rains of 1922 and the subsequent hurricanes of 1924, 1926 and 1928 dealt the region a series of damaging setbacks, wiping out most farmers and demonstrating that inadequate drainage still posed a major obstacle to profitable land cultivation. In fact, the 1928 hurricane caused Lake Okeechobee to swell violently and overflow its banks drowning nearly two thousand people in Belle Glade (Hollander 2008, 100).

Not wanting to lose the prosperous edge it had gained in the 1920 s, the State of Florida appealed to the federal government for assistance. Large-scale sugar growers also recognized that the nation's nascent "sugar bowl" taking hold on the peat soils south of Lake Okeechobee needed protection from too much water, so they too turned to the federal government for help (Hollander 2008) ${ }^{3}$.

\footnotetext{
${ }^{3}$ Florida sugar boosters, like Fred Williamson the vice-president of the Southern Sugar Company, underlined the importance of federally sponsored flood control for the region's productivity. Williams remarked "When [the control of excess water and adequate transportation] have been attained, all South
} 
In 1930, after some legislative maneuvering, Congress passed a Rivers and Harbors Act authorizing the US Army Corps of Engineers (Army Corps) to construct and maintain the Herbert Hoover Dike around Lake Okeechobee. The Army Corps completed the massive Herbert Hoover Dike in 1928. The Dike was "a phenomenal earthwork, 85 miles long, 125 to 150 feet at its base, rising 34 to 38 feet above sea level to girdle and obscure the lake" (Hollander 2008, 102). The Dike forever transformed Everglades hydrology, partitioning off the lake from the south Everglades and preventing its annual discharge into this part of the ecosystem. The Dike also ushered in an era of intense trusteeship by the US Army Corps of Engineers over Florida's water management system. Vileisis notes, "With the massive Corps levee, the federal government was finally drawn into having a direct stake in the Everglades. By 1942, the federal government had spent over $\$ 23$ million on the construction and maintenance of the south Florida project" $(1997,169)$.

Federal flood control in the Everglades culminated in 1947. After another powerful hurricane struck the region that year and caused severe flooding in its coastal communities, Congress directed the US Army corps of Engineers to study long-term flood control in the region. The Corps proposed a plan called the Central and Southern Florida (CS\&F) flood control project, which was designed to channel, dike and manage Everglades waters at an unprecedented regional scale.

Florida can develop, and the Everglades will truly be like a great factory creating new wealth for Florida out of Florida raw materials" (quoted in Hollander 2008, 100). Aware of the limitations of state coffers and their own ability to invest in water control infrastructure, these boosters wanted the federal government to fund, construct and manage south Florida's water control infrastructure. 


\section{The Tamiami Trail Opens an Extractive Frontier and Everglades National Park is}

\section{Created}

While sugar growers were working to get established south of Lake Okeechobee at the turn of the $20^{\text {th }}$ century, Miami was growing. Henry Flagler's Florida East Coast Railway arrived in Miami in 1896 prompting an influx of new settlers, tourists and businessmen. Almost simultaneously, the southern Everglades emerged as the next frontier to be conquered and tamed by human ingenuity.

An era of road, canal and rail construction began in the southern Everglades. New roads, including the storied cross-Everglades Tamiami Trail highway connecting Florida's east and west coasts, ended the region's isolation. These new roads also opened it up to farming and extraction. Widespread Everglades development alarmed scientists like John Kunkel Small who were interested in the Everglades' "rare tropicality". One site of particular interest for scientific discovery, the Royal Palm Hammock, was threatened directly (see Ogden 2008b). The Model Lands Company, a land development company, constructed a new road alongside the hammock so it could access its land holdings in the southern Everglades. John Ingraham, head of the Model Lands Company, worried that "Ingraham Highway" would open Royal Palm Hammock to citrus and sugar cultivation (Vileisis 1997) and imperil this scientific treasure. He approached the Florida Federation of Women's Clubs with his concerns. The Women's Club took up the cause, advocating for Royal Palm to become a public park. They wanted to protect and preserve Royal Palm's unique beauty and scientific curiosities. In 1916, they were able to secure the lands as a state park. Royal Palm State Park brought national attention to the 
biological values of the Everglades and provoked new questions about the cost of progress to south Florida's natural environment.

A protectionist "will to improve" was born from the developmentalist push to make the Everglades into a more productive landscape. The Royal Palm episode caught the attention of Stephen Mather, National Park Service director, who recommended the Everglades as a potential candidate for the National Park system (Vileisis 1997). But it wasn't until Coconut Grove landscape architect, Ernest Coe, embraced this idea, and formed the Tropic Everglades National Park Association with other coastal elites in 1928, that Mather's proposal gained traction.

Ernest Coe wanted to protect the unique natural beauty of the Everglades. He recognized it as a natural treasure endangered by the exploitation of the southern Everglades for natural resources during the 1920s. Coe lobbied high level Department of Interior officials and Congress to make this project a reality.

The push and pull between the developmentalist and the protectionist will to improve resulted in the advent of two improvement projects in 1947, which would be central to South Florida's future: 1) the Central and Southern Florida project, the largescale federal flood control intervention that was born in the wake of the powerful 1947 hurricane, and 2) the establishment of Everglades National Park in 1947.

\section{The Social Costs of Progress}

As Tanya Li asserts, the position of trusteeship is a "position of power." It privileges certain actors to make claims to and remake landscapes in ways that can adversely affect the lives of others. This has certainly been the case in the Everglades 
where improvement projects have ignored or effaced indigenous and poor white peoples' cultural histories in and claims to territory (albeit in different ways), relegating them to a space of marginality. These uneven power relations between environmental actors are what I call the environmental politics of progress. In the Everglades, white settler visions of progress and the desires of prestigious white scientists drove Everglades improvement projects (albeit in different directions) but displaced Native American claims and the claims of poor whites.

The literature demonstrates that the Everglades has a long history as a peopled landscape. Overall human use and habitation of the Everglades dates back over 2,000 years to a time period when the Tequesta and the Calusa were the dominant Glades Indians (McCalley 1999). These early peoples settled along south Florida's coasts and subsisted off of the Everglades' abundant natural resources. The Calusa were a powerful society of skilled shell-mound builders (Marquardt 1992, Milanich 1998). Yet, the era of European conquest, beginning with Spanish exploration in the $16^{\text {th }}$ century, decimated Florida's First Peoples through disease and violence (Brown 1994).

Florida became important to Native peoples once again during the $18^{\text {th }}$ century. Once part of the Muskogee/Creek nation of Georgia and Alabama, Native peoples called Seminoles moved to Spanish Territory (northern Florida) (Tiger and Kersey 2002, 5) to escape white settlement pressures. The word Seminole comes from the term "simanoli", a name borrowed from the Spanish word "cimarron." A term most often translated to mean "wild" or "runaway", it was used by the Creeks to describe their relatives who had settled in Spanish Florida (Cattelino 2009, Tiger and Kersey 2002, 7). The Florida Seminoles were made up of two linguistic groups - those who spoke Muskogee and those who 
spoke Hitchiti (Tiger and Kersey 2002). These linguistic differences would be part of the later official distinction between the Miccosukee (Hitchiti-speaking) and Seminole Tribes of Florida. ${ }^{4}$

The violence of Indian removal and the pressures of expanding white settlement followed the Seminole peoples into Florida, sparking a series of bloody conflicts between United States troops and Seminole peoples, known as the Seminole Wars. Andrew Jackson, first territorial governor of Florida, waged a military campaign against the Seminole peoples aimed at removing them from Florida in accordance with the Indian Removal Act of 1830. The Seminole peoples resisted for seven years in a bloody and drawn out conflict known as the Second Seminole War (1835-1842) (Tiger and Kersey 2002).

Seeking refuge from U.S. military raids during the Second Seminole War, Seminole peoples fled into south Florida's remote Everglades where they resisted removal, and waged guerilla warfare against the U.S. government (Bucuvalas et al. 1998, Tiger and Kersey 2002). During the 1840s, a handful of Seminole leaders took their bands deep into the Big Cypress Swamp and regrouped on its pine islands (Weisman 1999). The subsequent Third Seminole War, sparked by an incident between a land

\footnotetext{
${ }^{4}$ Political disagreements and cultural differences led to a split of the Seminole peoples into different federally recognized tribal nations. The Seminole Tribe of Indians of Florida organized and received federal recognition in 1957. However, another group of Seminole peoples, "the Miccosukee," refused to join or ally themselves with the Seminole Tribe. They lobbied for political recognition and sovereign rights apart from the Seminole Tribe. Shortly after 1962, the Miccosukee Tribe of Indians of Florida applied for self-determination or the right to control their own affairs. They were the first Indian tribe to sign a selfdetermination agreement with the federal government (Buffalo Tiger and Kersey 2002, 97). The Miccosukee Tribe wanted to be recognized as their own people. Buffalo Tiger describes how the Miccosukee peoples distinguished themselves from the Seminole peoples. He states that the Miccosukee peoples are the Eelaponke, "[a people] living in the water, hunting and fishing and riding canoes" who differed from the Seminole peoples in "language, lifestyle and government" (Buffalo Tiger and Kersey 2002, 79).
} 
surveying party in the Everglades and Seminole Chief Billy Bowlegs, took place mostly in the Big Cypress Swamp. In the Big Cypress Swamp, U.S. soldiers searched for Seminole outposts to try and forcibly relocate tribal members and quell Indian resistance (Goss 1995, Derr 1998, Weisman 1999). Only about 300 Seminoles survived the Third Seminole War (Tiger and Kersey 2002). At the close of the war, the remaining Seminoles dispersed into smaller bands composed of extended families. These bands settled deep in the Big Cypress Swamp, the Everglades or along the shores of Lake Okeechobee (Bucuvalas et al. 1998, Tiger and Kersey 2002).

Following the Seminole Wars, the Big Cypress Swamp would come to occupy a prominent place in Seminole history, more so than the southern Everglades (Weisman 1999). Yet both of these landscapes would became important homelands for Seminole peoples.

When Florida became a United States territory in 1821, there were approximately 8,000 white settlers living there (Kennedy 2009). These people were predominantly of Spanish descendent but also included a significant number of hardy Anglo-Saxon backwoodsmen of mostly Irish and Scottish descent (Kennedy 2009, 65-66). According to Stetson Kennedy, the latter were given the name "crackers," likely a phonetic interpretation of the word "cuacaros" (meaning Quaker) used by the Spanish to refer to these tough characters (Kennedy 2009, 65-66). Once Florida became a U.S. territory, there was an additional influx of poor white Scots-Irish settlers from the South in search of land and a better life, and of wealthy planters (Kennedy 2009). The Scots-Irish, some of the most economically marginalized of Florida's early settlers, sought to make their living off the land in the rural parts of the states, settling across the Palmetto Prairie in 
northern and central Florida (so named for the distinctive shaggy-crowned cabbage palm trees that punctuate the landscape) (Kennedy 2009).

White pioneer settlement of the southern Everglades followed the close of the Third Seminole War, unfolding during the last quarter of the $19^{\text {th }}$ century: roughly 1875 to 1900 (Tebeau 1977, Kersey 1975). Hardy and adventuresome pioneers mostly of Scotch-Irish descent came by boat and oxcart from the Carolinas, Alabama, Georgia and northern and central Florida (Bucavalas et al. 1998). They settled on the edges of the Everglades in places like Homestead, Chokoloskee, and small towns around Lake Okeechobee (Tebeau 1968, Ogden 2011). One well-known example of an early glades settlement was the small fishing village of Flamingo, which was situated at the terminus of Ingraham Highway along the shore of Florida Bay (Tebeau 1968). These early pioneers lived off the land - doing the backbreaking work to clear small plots and setup homesteads and truck farms, growing vegetables, citrus and sugar cane.

Early development, drainage and land protection projects (as described above) were overlaid on the existing mosaic of human use and occupation. There is no doubt that early Everglades improvement projects reshaped the livelihoods and lifeways of south Florida's rural whites and indigenous Seminole peoples.

Hamilton Disston imposed his vision of what the Everglades landscape should become (including who should settle it) on a socionatural landscape that he had scant knowledge about. In fact, much of the land sold to him by the state was not empty swampland (as purported) but piney woods and dry prairie already inhabited by a handful of white settlers and cracker cowmen (Derr 1998). As Mark Derr $(1998,89)$ has recounted: "The state's deal [with Disston] also failed to account for homesteaders with 
legitimate titles and for squatters with rights earned, they felt, by virtue of their occupancy. People living on the palmetto prairie, whose way of life Disston threatened to change, protested, prompting the State both to recognize legitimate claims and attempt to silence squatters by selling them their land at one dollar an acre." Clearly, Disston and the State of Florida paid these early settlers little regard - they did not fit into the dominant vision for improving the Everglades and creating prosperous farming communities. Disston made explicit that he wanted to reclaim and settle the lands he purchased on his own terms and with people of his choosing. The fiercely independent, itinerant and often impoverished white settlers already living on Disston's lands didn't fit his designs for the character, social status and financial means of the ideal smallholderso he excluded them from his improvement schemes, and ignored their claims to the landscape he had purchased. He wanted farmers who would learn certain farming techniques from his experts, and who would pay a share into to his projects, as evidenced by his Lake Conway project. ${ }^{5}$

Early drainage and reclamation projects in the Everglades and, later, the CS\&F flood control project were implemented without consulting the Seminole peoples who considered these landscapes their homeland (see Tebeau 1968, West 1998, Tiger and Kersey 2002, Cattelino 2009). Even though these Native Americans depended on the clean and abundant waters of the Everglades for subsistence and for their way life, they were relegated to a space of marginality in this larger developmentalist landscape.

\footnotetext{
${ }^{5}$ Disston sought to create the $19^{\text {th }}$ century equivalent of a master planned community in central Florida adjacent to Lake Conway. He built the town from the ground up, and recruited 250 hardworking families from northern states to purchase farms of twenty, thirty or eighty acres. He required each family to provide a grubstake of $\$ 1,000$ (see Derr 1998, 95).
} 
For example, the construction of the Tamiami Trail highway across the southern Everglades in the 1920s would forever change the livelihoods and lifeways of the Seminole peoples. While influential and wealthy white urbanites on Florida's coasts advocated for the road, the Seminole peoples were ambivalent ${ }^{6}$. Buffalo Tiger explains how a group of Seminole peoples who called themselves "Miccosukees" did not believe the Tamiami Trail would bring "progress" in the way non-Indians did (Tiger and Kersey 2002, 54). Instead, the Miccosukees wanted to be left alone to pursue their traditional lifestyle on lands that they considered their home.

Yet, white settler visions of progress prevailed. As Charles Tebeau observes, "The opening of the Tamiami Trail in 1928 might be termed the crucial factor in ending the Indians' old way of life (1968, 53-54). The "Trail" quickly turned an isolated frontier region into an active resource frontier. The primitive Tamiami Trail road permitted the passage of Model-T's across the southern Everglades and enabled non-Indian newcomers to access natural resources on surrounding lands. Looking to turn quick profits from nature's bounty, timber companies, clam canneries, commercial fishermen, hunters, land developers, plant and animal collectors and oil prospectors descended into the newly opened southern Everglades landscape to mine its natural resources (Tebeau 1968). The influx of white settlers and hunters, who "soon surpassed the Indians in the wild animal and bird trade" (Keller and Turek 1998, 221), forced the Seminole peoples to look for new income streams and disrupted their tradition lifeways.

Without the game and resources that traditionally sustained them, the Seminole peoples turned to the tourist economy for income where "...their culture itself became

\footnotetext{
${ }^{6}$ Coastal elites viewed the Tamiami Trail as an important commercial corridor for connecting east and west
} Florida and a critical access route into the resource rich lands of the southern Everglades (Jaudon papers). 
saleable" (West 1998, 3). As Florida's early population grew, so too did white people's interest in observing Seminole peoples perform their traditional lifeways. Seminole peoples began living in camps along the Tamiami Trail, where they sold crafts and opened their camps to tourists for a fee. As Patsy West has chronicled, "By 1930, well over half the $i$ :laponathli: [Seminole] population, even those in the isolated Big Cypress and in Collier County, had become involved tourist attraction employment, while virtually all of the population was engaged in supplying goods to this novel market" (West 1998, 9). White entrepreneurs too capitalized on tourist desires for indigenous wares and a glimpse into indigenous lifestyles. White businessmen purchased former trading posts like the one at Musa Isle along the Miami River, and turned them into tourist attractions that employed Seminole peoples to perform their culture (see Wiedman 2010).

Everglades National Park, created in 1947, was also fashioned from an existing mosaic of human use and occupation. The national park was overlaid on the already existing homeland of the Seminole peoples (as detailed above), and on landscapes central to the livelihoods and lifeways of rural white glades people. In many ways, prior to its protection, Everglades National Park was “a hunter's landscape” (Simmons and Ogden 1998, Ogden 2011), defined by the seasonal rhythms, movements and stories of glades hunters (notably, alligator hunters) as they traversed its wet prairies and tree islands in search of game. Many of these hunters, from surrounding rural towns like Homestead, depended on the Everglades as a source of supplemental income and food during hard times (Ogden 2011). 
Yet, the 1934 authorizing legislation for Everglades National Park describes Everglades National Park as a wilderness and emphasizes the importance of protecting its primitive condition and its unique flora and fauna. The legislation reads:

The said area or areas [designated as part of Everglades National Park] shall be permanently reserved as a wilderness, and no development of the project or plan for the entertainment of visitors shall be undertaken which will interfere with the preservation intact of the unique flora and fauna and the essential primitive natural conditions now prevailing in the area. (U.S. Congress 1934)

While this often-cited clause establishes important protections for the Park, it effaces the park's rich human history and its connections to nearby communities. Park proponents did acknowledge the presence of Seminole peoples on proposed parklands, noting that they kept farms and camps within the boundaries of the proposed park, and studied how to manage their presence (Keller and Turek 1998, Buffalo Tiger and Kersey 2002). However, when the NPS established the in 1947, it forced local and indigenous families to relocate (Cattelino 2008), and NPS regulations limited their ability to use the land in traditional ways. The NPS prohibited the harvest of alligators from the Park, and placed restrictions on the use of permanent backcountry camps as well as on the ignition of small wet season prairie fires to increase game density (Ogden and Simmons 1998, Ogden 2011). Moreover, the NPS banned Seminoles from living and hunting within the Park (Cattelino 2008). The creation of Everglades National Park was a 
jarring act of displacement for Native Americans who regarded the Park as their homeland, and for hardscrabble rural glades people who depended on hunting and fishing on parklands to make ends meet. In fact, national park creation precipitated an ongoing struggle between the Department of the Interior and the Miccosukee peoples.

Even after national park designation, the lands within the boundaries of Everglades National Park continued to be meaningful to local communities, especially gladesmen (who continued to hunt alligators there illegally, see Ogden 2011) and Everglades native peoples. To this day, the Miccosukee Tribe of Indians of Florida asserts customary use rights and aboriginal rights to lands within Everglades National Park, especially to those lands on the north boundary of the park that are home to Native villages. Thus, the Miccosukee Tribe of Indians of Florida continues to negotiate with the Department of the Interior over its rights to Everglades National Park (Keller and Turek 1998; see also Duncan 2007).

\section{An Enduring Developmentalist Will to Improve: The CS\&F Project, Post-WWII Suburbia, and the Making the Big Cypress National Preserve}

Post-WWII, the Everglades became a water source for and a land base to support unprecedented urban growth and development (in addition to a burgeoning agricultural sector). In fact, dreams of turning south Florida into an endless suburban mecca began to supplant those of transforming south Florida into an agricultural paradise. In fact, at the turn of the $21^{\text {st }}$ century, Florida's homebuilders surpassed its agriculturalists in political and economic influence (Barnett 2007). 
Florida experienced a land boom after WWII as former GIs, retirees and others permanently moved to the Land of Sunshine; a process enabled by the CS\&F project and part of the immense post-industrial population shift from the Rust Belt to the Sun Belt. Cynthia Barnett describes these massive population influxes, noting that: "From 1950 to 1970, Florida's population more than doubled, from 2.8 million to 6.8 million" (2007, 53). From 1970 to 1980, Barnett observes that Florida's population again increased from 6.8 million to 9.7 million, a period when "Florida had among the most extensive wetlands loss in the nation" (Barnett 2007, 55). Everglades wetlands were being rapidly transformed into suburban developments, especially in southwest Florida (Barnett 2007).

The CS\&F project made widespread suburban development possible. The CS\&F project was a vast armature of infrastructure including 1,000 miles of levees and canals, 15 square miles of interconnected water reservoirs, 150 water control structures and 16 major pumping stations, which continue to operate today (Ogden 2008a, 22). The creation of the CS\&F project ushered in a new era of comprehensive water impoundment and control by the federal government in south Florida. Yet, the CS\&F project radically altered and fragmented the Everglades; it was a massive reengineering of water flows across the ecosystem that produced a brand new kind of nature. This "second nature," as Hollander dubs it $(2008,6)$, was characterized by a series of reservoirs and water control features that required intensive human oversight and management. The Army Corps of Engineers had completely transformed the Everglades from its historic form as slowmoving, wide river of water (see Douglas 1947), and dismantled the elemental characteristics of the Everglades ecosystem: the seasonal pulse of water from Lake Okeechobee and the wetland's uninterrupted sheetflow - to make the regional suitable for 
widespread farming and settlement. Thus, the transformation of the Everglades into a fusion of nature, technology and human management was complete.

Michael Grunwald further chronicles how the CS\&F project remade south Florida to the detriment of the Greater Everglades Ecosystem. Grunwald notes that while the CS\&F project did a good job draining south Florida and delivering water to agricultural and urban development, it drastically disrupted the quantity, quality and timing of historic water flows across the Greater Everglades ecosystem, especially those into Everglades National Park. Grunwald writes:

The Everglades itself was no longer the Everglades. The northern Glades was overrun by sugarcane fields. The eastern Glades was overrun by suburbs. The central Glades was divided into 'water conservation areas' that still looked like the Everglades but were managed as reservoirs and sewers. And Everglades National Park was now the National Park Service's most endangered property... $(2006,240)$

Suburban development, land speculation and drainage were changing the Western Everglades too. The Big Cypress Swamp, a habitat mosaic of cypress strands, orchidstudded cypress domes, pine islands and vast marl prairies, and the largest wooded swampland in the United States (Kennedy 2009), was losing land to development on its western fringe. The Big Cypress Swamp, located to the north and west of Everglades National Park, sits at a slightly higher elevation than the Everglades ridge and slough system. Yet, the Gulf America Corporation (GAC) did not see its unique natural 
environments as intrinsically valuable. Instead, the GAC had their sights set on transforming the western edge of the Big Cypress into a SunBelt city. The GAC dug a vast network of canals across 160 square miles to make way for the Golden Gate Estates (Gore 1976, 262), while lowering the water table of the Big Cypress watershed and diverting large amounts of its vital freshwaters into the Gulf of Mexico.

But another group of people had different designs for the future of the Everglades. In the late 1960s and 1970s, environmentalists like Joe Browder, scientists like Arthur Marshall, concerned citizens and a handful of politicians, like advisor-to-the-governor, Nathaniel Reed, started agitating for the repair of the beleaguered Everglades. They were especially concerned about the state of Everglades National Park. Their efforts included Florida Governor Bob Graham's Save Our Everglades program, created in 1983, and Senator's Graham's legislative work to restore the Kissimmee River and to restore water flows to Everglades National Park in 1989 (Grunwald 2006). However, the proposal for a 39 square-mile Miami jetport project threatened their vision of progress - a rehabilitated Everglades.

In the late 1960s, Miami-Dade County officials, developers, and real estate speculators all supported plans to turn the Big Cypress Swamp into an international airport, known as the Everglades jetport (Davis 2011). They viewed the jetport as a boon to regional development, and an opportunity to rebrand Miami. The swamp was again seen as intrinsically worthless. The airport idea, clearly the product of high modern hubris, would accommodate supersonic jets on six one-mile long runways (Grunwald 2006, Davis 2011). Proponents argued it would squarely situate Miami on the map as a cosmopolitan and innovative regional center instead of a backwater (Davis 2011). The 
jetport proposal sparked a new wave of land speculation across the Big Cypress Swamp, as citizens and investors sought to capitalize on the airport's planned development.

Environmentalists were worried by the proposal and the irreversible ecological damage it would inflict on an already degraded Everglades (Davis 2011).

Conservationists argued that the Big Cypress Swamp captured and delivered vital freshwater into the western reaches of Everglades National Park, which was already starved of water because of the CS\&F project. They believed that the end of Big Cypress meant the end of Everglades National Park. As Rick Gore observed, "Jetport development, conservationists contended, would mean the park's gradual death by thirst" (1976, 254). In their minds, the jetport imperiled the Western Everglades and Everglades National Park.

Spearheaded by Joe Browder, environmentalists advocated that the Big Cypress be protected, not developed (Davis 2011). Browder, in particular, reached out to longtime hunters and outdoorsmen who intimately knew and loved the wild lands of Big Cypress Swamp, to enlist their help (Russell 2007). In an epic act of compromise, longtime hunters and outdoorsmen allied with environmentalists to lobby the federal government and save the Big Cypress from what they perceived to be an ugly and illogical fate (Russell 2007, Davis 2011).

Yet, powerful developmentalist interests were behind the jetport. An acrimonious debate about the jetport's merits and its adverse effects on Everglades National Park (and southwest Florida's water supply) ensued, reaching into the upper echelons of the Nixon Administration (Davis 2011). President Nixon ultimately opposed the jetport, shutting down any possibility for the project in a speech where he proclaimed that the 1970s 
would be the decade of the environment (Grunwald 2006, 258). The jetport proposal put the Big Cypress Swamp on the map as a critical natural landscape in need of protection (Gore 1976), while the intense drought and related wildfires of 1971 further underscored the plight of the Everglades. In 1974, the National Park Service stepped in to protect these lands as the country's first National Preserve (Davis 2011).

\section{Human History of the Big Cypress National Preserve}

Like Everglades National Park, the Big Cypress National Preserve was overlain on a landscape with a rich and deep human history. The Big Cypress Swamp was a place shaped by Seminole and Miccosukee peoples, white soldiers, white settlers, white hunters and African American laborers among others.

The Big Cypress Swamp is an important homeland for the Seminole and Miccosukee peoples. The Swamp is an important site in their cultural history and for their present-day cultural survival. As detailed above, the Big Cypress Swamp became a refuge and homeland to the Seminole peoples after the Second Seminole War drove them deep into the Everglades. It was also the principle battleground for the Third Seminole War. Seminole peoples continue to assert cultural and religious claims to the Big Cypress. Today, the Preserve is home to several active ceremonial sites and Native gravesites (Goss 1995). Moreover, several clans live in small villages along the Tamiami Trail on lands within the Preserve's boundaries, and collect wild plants for medicinal purposes (Goss 1995). The Preserve's authorizing legislation grants customary and traditional use rights to both the Miccosukee and Seminole Tribes of Florida. 
In addition, complex white settlement histories animate this landscape ${ }^{7}$. My oral histories with multi-generational native Floridians and long-time white hunters reveal that these lands were settled, farmed, ranched, and hunted from the late 1800s on and have been explored by the oil industry since 1930. These lands were "rode hard" as one of my respondents put it (interview April 11, 2011).

A handful of Florida's early hardscrabble white pioneers lived adjacent to the Big Cypress Swamp in the coastal town of Everglades (now called Everglades City), and later on small homesteads near Ochopee, or in company towns associated with logging or citriculture. Many of these early white pioneers were employed by natural resource extraction industries, and labored to advance the region's road-building, farming, logging, and development enterprises. Both African American and white laborers worked in the region's logging camps, harvesting its giant cypress trees for use as building material for war ships during WWII (Peterman and Peterman 2003). White settlers and Native Americans also farmed and packed tomatoes, one of the area's staple crops. Some Florida natives maintained claims to lands in Big Cypress until it was designated a National Preserve by the federal government in 1974 (interview April 11, 2011). In this way, the swamp indelibly shaped the family histories and fortunes of Florida's native and pioneer families.

The Big Cypress Swamp was a hunter's landscape too. My interviews reveal that commercial, subsistence and recreational hunting practices shaped it (interview April 11, 2011, interview May 25, 2011). In the early years of frontier settlement, glades families depended on this landscape for their survival (Tebeau 1977). The completion of the

\footnotetext{
7 The Big Cypress Swamp was also home to African American settlers and laborers. Many African
} Americans worked in logging camps. For a more complete history see Peterman and Peterman 2003. 
Tamiami Trail roadway in 1928 opened up this once-isolated place to more widespread exploration and hunting by coastal and rural dwellers (Tebeau 1977). After Everglades National Park was established in 1947, the Big Cypress Swamp became a refuge for commercial alligator hunters and other game hunters (Tebeau 1977, Russell 2007, Davis 2011). Many lived in or frequented the rural town called Pinecrest, situated deep in the cypress along the Loop Road (Tebeau 1977, Russell 2007, Davis 2011). Once the State of Florida outlawed alligator hunting, many of the area's residents turned to making a living "the 'glades way" by frog gigging.

From about the 1940s on the Big Cypress Swamp became home to a distinct form of rural hunting culture with certain cultural practices including the construction of backcountry camps, and the use of homemade swamp buggies and airboats for travel across this rough terrain. Interviews with outdoorsmen described how hunters from coastal cities and towns like Miami and rural enclaves like Labelle, Florida setup backcountry hunting camps - or simple shelters- that were sometimes makeshift, sometimes permanent on the higher ground afforded by hammocks and pinelands across the Big Cypress region. These camps were typically accessible via swamp buggy or airboat. There were hundreds of these camps located throughout the swamp - which was described to me in an interview as "a vast commons" (interview April 11,2011) and elsewhere by Jack Knight as “[Florida's] last frontier, the last great swamp” (Gore 1976, 266).

The introduction of airboats and swamp buggies (and their subsequent technological advancement) allowed hunters to transport building materials into "the cypress" as locals call it. Hunters were then able to construct rustic lean-tos or small 
cabins on their preferred campsites. Some hunters held proper land title but many of these camps were built through informal agreements with larger landowners or as squatter structures. These shelters allowed outdoorsmen to spend multiple nights in the backcountry and claim a favorite spot as their own. In fact, my archival research shows that there were between 500 and 600 hunting camps in the Big Cypress Swamp when the NPS began acquiring these lands in 1974 (Big Cypress Papers).

The founding and construction of these backcountry camps marked an important era in the history of the southern Everglades - it was a time when the lifestyles and lifeways of surrounding rural enclaves were intimately tied to the region's wild lands. For many outdoorsmen in rural communities like Homestead, LaBelle and Parrish, Florida (as well as outlying Miami suburbs like Hialeah and Miami Gardens), "the cypress" was a meaningful refuge for recreation and relaxation - it was a place to get away from the rigors of daily life and maintain a sense of place-based identity in a changing landscape. From the late 1940s on, rural hunting practices and glades hunters' ability to travel across the southern Everglades were increasingly constrained by development and population pressures, and the decreasing availability of open space and wild lands.

\section{The Designation of the Big Cypress National Preserve}

The Big Cypress National Preserve was the first National Preserve authorized by Congress for management by the National Park Service. The National Preserve was conceived of as a new category of NPS multi-use land protection. Congress intended for a National Preserve to protect the natural values of a landscape but to allow for more uses than a national park, including hunting, oil and gas extraction and more significant 
recreational use, including off-road vehicles (Goss 1995, 4). The Preserve's enabling legislation states that the Preserve was created: "to assure the preservation, conservation, and protection of the natural, scenic, hydrologic, floral and faunal, and recreational values of the Big Cypress Watershed" (US Congress 1974a). Congress underlined that the primary purpose of a National Preserve was nature preservation, minimizing the importance of any human history. Congress further articulated that National Preserves should protect landscapes with "exceptional values or qualities illustrating the natural heritage of the Nation" and that "all management activities within these areas should be directed toward maintaining the natural and scientific values of the area" (U.S. Congress 1974b).

Once Congress created the Preserve, the National Park Service had to acquire the patchwork of private lands within the Preserve's boundaries, some of which were hunting camps owned or squatted on by outdoorsmen. In fact, there were over 70,000 privately owned land parcels dotting the lands destined to become the Big Cypress National Preserve (Duever 1986). Certain hunters who owned the title to their land were able to keep their camp and a small amount of acreage, but most hunters lost their camps. Today, there are approximately 100 private landowners in the Big Cypress National Preserve who have backcountry hunting camps or inholdings (interview with NPS staff, May 2, 2012). Swamp buggy use and other motorized access to this landscape as well as hunting are permitted but these activities have been redefined as a recreational uses under the regulation of the Secretary of the Interior (US Congress 1974a).

Yet, the backcountry in the Big Cypress National Preserve continues to be a storied cultural landscape that reverberates with tales of community, hardship, survival, 
and meaning for outdoorsmen. Even today, a rich variety of backcountry camps remain. From my in-depth interviews with self-identified gladesmen, and other outdoorsmen, including camp owners in the Big Cypress, it is clear that these camps are important material and cultural touchstones for outdoorsmen. Outdoorsmen repeatedly recounted how these camps serve as stopover and jumping off points for hunting trips, sites for important community and family events, shelters during intense lightning storms and places where larger-than-life stories about swamp life are told and retold. Importantly, my interviews with outdoorsmen underlined how these camps have helped them to maintain a sense of community and a strong connection to the Everglades within a rapidly urbanizing southern Florida. An article by "Gatordan" published on the Airboat Association of Florida's webpage in 2010 highlighted the social importance of these camps. These camps are places that have given rise to unique social relations. In the article, he states "As the owners of the hammocks are forced to sell... all the pranks, kids laughing, mud fights, fishing expeditions, scary campfire stories, life long friendships, our heritage [will be gone]" (quoted in Ogden and Memory 2012, 94)

The stories of contemporary outdoorsmen underline the continuing social resonance of the Big Cypress National Preserve for this community of people. However, the practices and the history of cypress hunting are effaced by the Congressional construction of the Preserve as a nationally significant conservation landscape.

\section{Ecological Restoration: Rehabilitating and Redefining the Everglades}

Early efforts to restore the Everglades began in the 1970s, but culminated with the Congressional authorization of the Comprehensive Everglades Restoration Plan (CERP) 
in 2000. In the 1970s, the deleterious environmental effects of south Florida's earlier wetland reclamation efforts became visible. The timing and distribution of Everglades waters, which had once flowed unimpeded, had been dramatically restructured by wetland reclamation projects, most notably the massive Central and Southern Florida Project.

The CS\&F's adverse consequences became painfully apparent in Everglades National Park, starving the park landscape of so much water that it almost completely dried out and was plagued by intense fires. These events sparked a series of Congressionally mandated projects focused on restoring the hydrology of the Everglades watershed (U.S. GAO 2007, Doyle 2008), which culminated with the Congressional authorization of the Comprehensive Everglades Restoration Plan or CERP in 2000. The product of consensus between Florida's diverse and often divided water interests, CERP aims to "get the water right" or restore the quantity, quality, timing and distribution of water flows to mimic historical water conditions across the Everglades as closely as possible. In principle, Everglades restoration is focused on improving the ecological integrity of this vast ecosystem, yet critics and environmentalists have often wondered whether growing water supply demands for agriculture and urban growth weren't the real drivers behind this initiative (Grunwald 2006, Clarke 2007). During Jeb Bush's tenure as Florida governor, he founded the Acceler8 program under CERP. While not explicitly stated, this program freed up more state funding for and focused on speeding up the implementation of eight of the 68 CERP projects. The CERP projects targeted by Acceler8 were those that would create additional water supply for southeast Florida's farms and cities (Barnett 2007, Clarke 2007). 
Thus, the developmentalist impulse continues today as different group vie to transform Everglades restoration in ways that fuel their own dreams of progress. Moreover, Everglades restoration is a massive re-engineering of the Everglades that requires the same kinds of technical expertise and intervention that created the CS\&F project. Ironically, the U.S. Army Corps of Engineers continues as its primary trustee. The Corps works to construct large public works like large reservoirs, highway bridges and spreader canals under the auspices of Everglades restoration, re-assembling the current spatial assemblage of nature, human management and technology.

Everglades restoration has also changed the way the Everglades is managed and understood as a place. Everglades restoration is premised on the concept of the ecosystem and the principles of ecosystem management, "reflecting the popularity of ecosystem approaches within U.S. environmental mitigation and conservation efforts as well as academic ecology" (Ogden 2011). But the ecosystem as a way of understanding nature in the Everglades has evolved into a vision of this landscape as an amalgam of water, flora and fauna that externalizes humans and is managed and known through technoscience (see Ogden 2008a).

As a result, Everglades restoration has taken shape as a multi-purpose water management plan, reflecting the priorities and the scientific expertise of its administering agencies - the U.S. Army Corps of Engineers and the South Florida Water Management District (Cattelino 2008, 2009; Ogden 2008, 2011). In effect, Everglades restoration projects often exclude other forms of knowledge, which don't fit with the institutional mandates and expert practices of these agencies. For example, local glades people's working knowledge and connections to the landscape appear in project appendices as 
public comments but are minimized in actual project designs or addressed under the purview of recreational use. Moreover, Florida's Native peoples are not full partners in Everglades restoration, afforded the status of stakeholders when they are the sovereign equals of the United States government (Cattelino 2009). Ultimately, Everglades restoration recasts the Everglades as a national and natural treasure whose waterscapes are seemingly devoid of human presence and best managed by science.

Yet, as scholars have shown, the exclusions and effacements of local territorial claims and histories are not one-directional. These claims do not disappear, but often return from the margins to contest and complicate future improvement projects. This process is happening in the Everglades. Since 1950, the Seminole peoples and Miccosukee peoples have attempted to reterritorialize their claims to Everglades lands and waters through lawsuits, negotiations and the development of Indian-run water management projects (see Cattelino 2008, 2009). In addition, new oppositional environmental subjectivities are emerging on the part of white outdoorsmen who selfidentify as Gladesmen in the contemporary moment (as discussed in Chapter 6), as the environmental politics of progress in the Florida Everglades shift once again.

\section{Conclusion}

As Laura Ogden (2008b, 2011) documents, different kinds of landscapes make for different environmental politics (what she terms "the politics of nature") because they result in different power asymmetries among humans and nonhumans. As I have shown, diverse improvement projects animated by developmentalist and protectionist wills to improve have transformed the Everglades. As a result, South Florida has emerged on the 
one hand as an iconic conservation landscape defined by concerns about its wilderness, water, ecosystem restoration and biodiversity and on the other as a SunBelt "paradise" of endless tourist attractions and vast subdivisions all while relegating to the margins the claims of local peoples to the Everglades landscape. Detailing the ways Everglades improvement projects have spatially and discursively reshaped the Everglades assemblage across time and space sets the stage for understanding the contemporary debates about ecosystem restoration and land management strategies in the southern Everglades, and the ways these struggles have produced new environmental claims and environmental subjectivities. 


\section{REFERENCES}

Barnett, Cynthia

2007 Mirage: Florida and the Vanishing Water of the Eastern U.S. Ann Arbor, MI: University of Michigan Press.

Big Cypress Papers

1983 Letter from Michael Watkins, President of Coalition of Concerned Citizens, to Secretary of the Interior James Clark, Dec. 7. BICY 14661. Series I, Box 1. South Florida Collections Management Center. Everglades National Park, Homestead, FL.

Blake, Nelson Manfred

1980 Land into Water - Water into Land: A History of Water Management in Florida. Gainesville, FL: University Presses of Florida.

Brown, Robin C.

1994 Florida's First Peoples. Revised ed. Pineapple Press: Sarasota, FL.

Bucuvalas, Tina, Peggy A. Bulger, and Stetson Kennedy

1994 South Florida Folklife. Folklife in the South Series. Jackson, MS: University Press of Mississippi.

Cattelino, Jessica R.

2008 High Stakes: Florida Seminole Gaming and Sovereignty. Durham, NC: Duke University Press.

2009 Florida Seminoles and the Cultural Politics of the Everglades. Occasional Paper from the School of Social Science, Institute for Advanced Study. May 2009. Paper Number 36.

Clarke, Alice L., and George H. Dalrymple

2003 "\$7.8 Billion for Everglades Restoration: Why Do Environmentalists Look So Worried?" Population and Environment 24 (6): 541-569.

Davis, Jack E

2011 An Everglades Providence: Marjory Stoneman Douglas and the American Environmental Century. Athens, GA: University of Georgia Press.

Derr, Mark

1998 Some Kind of Paradise: A Chronicle of Man and the Land in Florida.

Gainesville, FL: University Press of Florida. 
Doyle, Mary

2008 "The Everglades." In Large-scale Ecosystem Restoration: Five case studies from the United States, eds. Mary Doyle and Cynthia Drew, 1-2. Washington, DC: Island Press.

Escobar, Arturo

1995 Encountering Development. Princeton, NJ: Princeton University Press.

Ferguson, James

1994 The Anti-politics Machine: "Development", Depoliticization, and Bureaucratic Power in Lesotho. Minneapolis: University of Minnesota Press.

U.S. Government Accountability Office (U.S. GAO)

2007 South Florida Ecosystem Restoration Is Moving Forward but Is Facing Significant Delays, Implementation Challenges, and Rising Costs. Report for House Committee on Transportation and Infrastructure. Washington, DC: GPO. GAO-07520

Goldman, Mara J. and Matthew D. Turner

2011 Introduction. In Knowing Nature: Conversations at the Intersection of Political Ecology and Science Studies, Mara J. Goldman, Paul Nadasdy and Matthew D.

Turner, eds. Chicago: University of Chicago Press.

Goss, James A.

1995 Usual and Customary Use and Occupancy by the Miccosukee and Seminole Indians in Big Cypress National Preserve, Florida. Project Report D-121. Atlanta, GA: U.S. National Park Service, Southeast Region.

Gore, Rick

1976 “Twilight Hope for Big Cypress.” National Geographic 150 (2): 251-273.

Grunwald, Michael

2006 The Swamp: The Everglades, Florida and the Politics of Paradise. New York: Simon and Schuster.

Herzfeld, Michael

2001 Anthropology: Theoretical Practice in Culture and Society. Wiley-Blackwell.

Hollander, Gail M.

2008 Raising Cane in the 'Glades: The Global Sugar Trade and the Transformation of Florida. Chicago: The University of Chicago Press.

Keller, Robert H, and Michael F Turek.

1998 American Indians and National Parks. Tucson: University of Arizona Press. 
Kennedy, Stetson

2009 Palmetto Country. Cocoa, FL: Florida Historical Society Press.

Kersey Jr., Harry A.

1975 Pelts, Plumes and Hides: White Traders Among the Seminole Indians 1870-1930.

Gainesville, FL: University of Florida Press.

Li, Tania Murray

2007 The Will to Improve: Governmentality, Development and the Practice of Politics.

Durham, NC: Duke University Press.

Marquardt, William H.

1992 Culture and Environment in the Domain of the Calusa. Monograph No. 1.

Institute of Archaeological and Paleo-Environmental Studies: Gainesville, FL.

McCally, David

1999 The Everglades: An Environmental History. Gainesville: University of Florida Press.

Milanich, Jerald

1998 Florida's Indians from Ancient Times to the Present. University Presses of

Florida: Gainesville, FL.

Mitchell, Timothy

2002 Rule of Experts. Berkeley, CA: University of California Press.

Ogden, Laura

2011 Swamplife: People, Gators and Mangroves Entangled in the Everglades.

Minneapolis: University of Minnesota Press.

2008a The Everglades Ecosystem and the Politics of Nature. American Anthropologist 110(1): 21-32.

2008b Searching for Paradise in the Florida Everglades. Cultural Geographies 15: $207-$ 229.

Memory, Melissa and Laura Ogden

2012 [In preparation] Cultural Landscape of Everglades National Park: Ethnographic Overview and Assessment Report. U.S. National Park Service, Everglades National Park, Homestead, FL.

Peterman, Audrey and Frank.

2003 African Americans and the Sawmills of Big Cypress: A Brief History. Contract \# P5120021078. U.S. National Park Service, Big Cypress National Preserve, Ochopee, FL. 
Reisner, Mark

1993 Cadillac Desert: The American West and its Disappearing Water. Revised Edition. New York: Penguin Books.

Russell, Nancy.

2007 Interview with Joe Browder in Everglades City. Dec. 7 transcript. EVER-1410.

South Florida Collections Management Center, Everglades National Park,

Homestead, FL.

Scott, James C.

1998 Seeing Like a State : How Certain Schemes to Improve the Human Condition

Have Failed. Yale Agrarian Studies. New Haven: Yale University Press.

Tebeau, Charlton

1968 Man in the Everglades: 2000 Years of Human History in the Everglades National

Park. 2nd edition. Copeland Studies in Florida History, No. 3. Miami, FL: University of Miami Press.

1977[1957] Florida's Last Frontier: The History of Collier County. Paperback edition.

Copeland Studies in Florida History, No. 1. Miami, FL: University of Miami Press.

Tiger, Buffalo and Harry A. Kersey Jr.

2002 Buffalo Tiger: A Life in the Everglades. Lincoln, NB: University of Nebraska Press.

\section{U.S. Congress.}

1974a. Senate Committee on Interior and Insular Affairs. Senate Report 93-1128. $93^{\text {rd }}$

Congress. $2^{\text {nd }}$ Session.

$1974 b$

Vileisis, Ann

1997 Discovering the Unknown Landscape: A History of America's Wetlands.

Washington, D.C.: Island Press.

Weisman, Brent Richards

1999 Unconquered People: Florida's Seminole and Miccosukee Indians. Gainesville, FL: University Press of Florida.

Wiedman, Dennis

2010 "Global Marketing of Indigenous Culture: Discovering Native America with Lee Tiger and the Florida Miccosukee." American Indian Culture and Research Journal 34 (3): 1-26.

West, Paige

2006 Conservation Is Our Government Now: The Politics of Ecology in Papua New Guinea. Durham, NC: Duke University Press. 


\section{West, Patsy}

1998 The Enduring Seminoles: From Alligator Wrestling to Ecotourism. Gainesville, FL: University Press of Florida. 


\section{Chapter 2: The Hydropolitics of Environmentalism in the Florida Everglades}

\section{Defining Everglades Hydropolitics}

The late afternoon sun slants through the blinds as I sit in an elegantly furnished conference room squinting at a PowerPoint presentation. The waning sunlight washes out the screen, and makes me think of cloudy water rushing over Everglades marsh grass. To my left and to my right at the conference table are representatives of other environmental NGOs who are part of the Southern Everglades Advisory Council (SEAC). The SEAC is a group of ENGOs engaged in Everglades Restoration advocacy, who receive funding from the Everglades Foundation, an environmental NGO (ENGO) committed to advancing Everglades restoration. Most of the environmental advocates sitting around the table are young professional women, like myself, between the ages of 25 and 35 who hold professional or advanced degrees. As we gaze attentively at the screen, National Park Service staff flip through a series of engineering schematics that demonstrate how the raising of the Tamiami Trail highway and the resultant increase in water depth and flow under this highway and into Everglades National Park - water badly needed to improve environmental conditions the Park - will affect tribal residences as well as the commercial and private airboat operators who use these parklands. In my role as policy fellow for the Everglades Foundation, I convened this meeting to help other Everglades ENGO staff better understand the current complexities of the Tamiami Trail restoration project. From the slides and the information available, it is clear that the anticipated volume of water will submerge a significant extent of several of the properties in question, changing their character and spatial layout. I ask Park staff what strategies are 
available to overcome these restoration challenges. Park staff explain matter-of-factly that it would be best to purchase these properties, in accordance with a 1989 Congressional Act, if possible, and, in cases where this was not possible, to work with the property owners to mitigate the floodwaters by, for example, raising the land with fill or brokering flowage easements. While these are perfectly reasonable technical suggestions, as an anthropologist-in-the-making I can't help but feel uneasy. I find myself wondering: What kind of position gives ENGOs the right or ability to comment on the lives and futures of others, and how did ENGOs carve out this role in Everglades advocacy? In effect, how did ENGOs become Everglades trustees - organizations that state agencies and other actors often look to for comments on or assistance with protecting and restoring the Everglades?

In this chapter, I examine the hydropolitics of environmentalism in the Florida Everglades. First, I examine the rise of ENGOs as influential Everglades trustees and I document how water - which has become the defining element of Everglades restoration has created a strategic opening for ENGOs to assume a position of environmental trusteeship in the Florida Everglades. Building on the work of Tanya Li (2007), I understand trusteeship as a position of power and a social relationship integral to development projects, which privileges certain experts to define and implement improvement schemes that affect the lives of others. In this chapter, I also document how the material and symbolic properties of water make it a compelling object for environmental advocacy, and how water has created discursive commonality among diverse ENGOs. Finally, I show that while water has become an important advocacy tool for Everglades ENGOs, the Everglades ENGO community remains a heterogeneous 
group of organizations with varied identities and priorities - both unified and divided by the issue of water. I refer to the ways water enables and constrains, and unifies and divides ENGOs in Everglades environmental politics as hydropolitics. My analysis is informed by critical scholarship by Tanya Li (2007) on the practice of politics in green governmentality, Tracey Heatherington's (2010) work on the role of ENGOs in environment and development projects as well anthropological work on how environmental struggles are power-laden but fluid and dynamic (Brosius 1999). In particular, in this chapter, I extend Li's analysis by complicating the category of trusteeship. I look at how ENGO trusteeship comes into being in the Florida Everglades, how trustees challenge one another's authority and how trusteeship is itself a messy category.

\section{Background: Everglades Restoration, A Development Project}

Everglades restoration is officially a large-scale ecosystem restoration project. Specifically, it is a partnership project between the state and federal governments designed to rehabilitate south Florida's degraded wetland ecosystem by implementing over 68 different ecosystem restoration projects aimed at "getting the water right" (SFERTF 2000, NAS 2010). Yet, Everglades restoration is also a quintessential development project ${ }^{2}$ because it is linked to enhancing the sustainability of the south

\footnotetext{
${ }^{1}$ What this phrase, "getting the water right," means is that scientists, engineers and water managers will work together with concerned interest groups to repair the quality, quantity, timing and distribution of water across the Everglades so that it mimics historic patterns as closely as possible while providing adequate water supply and flood protection to south Florida's more than seven million inhabitants.

${ }^{2}$ Development is premised on the belief that expert technical interventions in forms such as engineering, economic policy, biomedicine and biology can always transform places into more productive, modern and
} 
Florida region. The State of Florida, the United States federal government and ENGOs characterize Everglades restoration as a project designed to benefit people and nature by improving south Florida's environmental quality and water supply. As I chronicle below, in the events leading up to the official Congressional authorization of Everglades restoration in 2000 and since, environmental NGOs (ENGOs) have emerged as important Everglades trustees.

In her critique of Lore Lindu National Park, an integrated conservation and development project in Indonesia, Tanya Li (2007) describes how development projects are premised on the will to improve - that is, development proponents' motivation to enhance the condition of a population or environment. Li argues that development is defined by the social relation or position of trusteeship - the idea that certain development actors possess the expertise uniquely suited to improving social and natural environments and, thus, have the skills to direct and enhance the lives of others. As Li articulates, trusteeship is "a position defined by the claim to know how others should live, to know what is best for them, to know what they need" (Li 2007, 4). In development projects, trusteeship occurs when an organization or actor defines a problem at hand in such a way as to position itself as possessing the unique technical or other expertise necessary for solving that problem. Li calls this process the act of "rendering technical." In this way, trusteeship is premised on the ability to translate messy realities into compelling "linear narratives of problems, interventions and beneficial results" (Li 2007,4). Yet, as Li notes, any claim to be able to "optimiz[e] the lives of others is a claim to power, [and] one that merits careful scrutiny" $(2007,5)$

prosperous forms. The underlying assumption is that human reason can re-order the social and natural 
There is no question that ENGOs make claims about the Everglades and advocate for certain kinds of restoration solutions and outcomes. ENGOs are an integral part of the complex, multi-scalar shifting coalition of state and non-state actors (Brosius 1999) who today make up the political apparatus of Everglades restoration and stewardship. Representatives of ENGOs like Audubon of Florida, the Everglades Foundation, the National Parks Conservation Association, Defenders of Wildlife and the Sierra Club sit on Everglades restoration advisory boards, and weigh in through public planning processes on the management, protection and restoration of the Everglades. These ENGOs focus on ensuring that the environment receives its fair share of clean water under Everglades restoration and, in their advocacy campaigns, these ENGOs foreground the importance of protecting Everglades water resources from pollution and overuse.

Yet, the emergence of ENGOs as central players in Everglades stewardship is recent. Moreover, water has not always been at the forefront of environmentalist concerns about the Everglades. In fact, early preservationist campaigns focused on protecting the Everglades "primitive" character and its unique flora and fauna.

\section{The Rise of Everglades Environmental NGOs and the Everglades Waterscape}

In this section of paper, I examine how the role of ENGOs as Everglades trustees is historically constituted and linked to the politics of Everglades water management. I demonstrate how early Everglades preservationists were not focused on protecting

\footnotetext{
worlds to bring about maximum social improvement. See Escobar 1995 and Mitchell 2002.
} 
Everglades water. Yet, since $1947^{3}$, I argue that the three most definitive struggles over saving the Everglades have focused on water distribution and water quality. I describe these three water management struggles: 1) the inadequate delivery of water to Everglades National Park resulting from unequal water distribution under the Central and Southern Florida flood control project, 2) degraded Everglades water quality and 3) concerns about the fair distribution of water across the Greater Everglades under Everglades restoration. Then, I trace how these three struggles revealed shortcomings in the state's management of water, opening an important space for ENGOs to assume the position of Everglades trustees and shifting power from state agencies to ENGOs (but also constraining ENGOs to continue to work with state agencies and governments). In this section I draw upon and extend Tanya Li's ideas about the politics of environmental struggle. Building on Foucault's work (2000a, 2000b) on the perpetual linking and perpetual reversal of power relations, Li defines the power relations of improvement projects as the tension between "the practice of government" and "the practice of politics" (2007, 11-12). Li views the practice of government as the act of translating visions for improvement into calculated and technical projects for implementation, while the practice of politics is "the expression... of critical challenge... [to the practice of government, which] opens up a front of struggle" (2007, 12). She continues, "this front may or may not be closed as new problems are rendered technical and calculations applied" $(2007,12)$. Thus, struggles over environmental improvement are characterized by the openings and closings of power whereby the power

\footnotetext{
${ }^{3} 1947$ marks a significant year in Everglades history. It was the year that Everglades National Park was officially established and the year that Congress approved the Central and Southern Florida (CS\&F) flood control project for implementation by the US Army Corps of Engineers.
} 
of trusteeship is not totalizing but instead subject to disjuncture and contradictions that leave it open to challenge and resistance, which can open up new spaces of power for other environmental actors. As Li observes, the practice of politics poses a limit to the practice of government, and I explore the way this dynamic causes the balance of power to shift between trustees. As Li remarks, there is the "ever-present possibility that a governmental intervention will be challenged by critics rejecting its diagnoses and prescriptions" $(2007,17)$. Li argues that the "will to improve" creates two distinct subject positionings - trustees and deficient subjects "whose conduct is to be conducted" (2007, 24). However, in this paper, I am interested in the power struggles for the position of trusteeship that take place between state agencies and ENGOs.

\section{Early Everglades Preservation}

Early on, water was not the defining issue for Everglades preservationists. ${ }^{4}$ Instead, from the turn of the $20^{\text {th }}$ century on, the Everglades was prized for its "primitive" character, its biologic value and its wildlife (Runte 1979, NARA IIa). Preservationists sought to protect the Everglades from resource exploitation and development.

Preservationist interest in the Everglades arguably began with the National Audubon Society's single-issue campaign to end plume bird hunting in the early $20^{\text {th }}$ century. As Michael Grunwald (2006) has chronicled, glades hunters were intensively harvesting wading birds like the white egret from Everglades rookeries. These plume hunters sold

\footnotetext{
${ }^{4}$ As Kay Milton $(1996,74)$ observes, since the days of John Muir and Gifford Pinchot's epic battle over the damming a river in Yosemite National Park, there have been two broad categories of environmentalism: preservation and conservation. As Milton explains, preservationists typically advocate for the protection of nature from human use while conservationists believe nature should be conserved, or protected, for human
} 
the birds' feathers to New York fashion industry magnates, who used them to make stylish women's hats. The National Audubon Society worked tirelessly to end this practice. They asserted that by destroying plume birds, plume hunters were destroying one of the defining attributes of the Everglades that made it unique and special. National Audubon Society successfully elevated this issue to the national stage, galvanizing Americans around the issue of bird protection in the Everglades. After one of Audubon's game wardens, Guy Bradley, was killed at the hands of plume hunters, public outcry was so great that the New York State legislature voted to ban the import of plume feathers. This legislation effectively put an end to Everglades plume hunting.

Preservationists then devoted their energies to protecting a large land area in the southern Everglades. They feared that the pressures of agricultural development, resource extraction and logging would forever transform all of the wild Everglades, if they didn't intervene (NARA IIa). Their efforts culminated in the establishment of Everglades National Park in 1947 (Grunwald 2006, Davis 2011). Everglades National Park was the nation's first biologic park, explicitly created to protect its flora and fauna rather than its scenic values, marking an important shift in National Park Service philosophy from the enshrinement of scenic monumentalism to the preservation of biological value (Runte 1979, Davis 2011). In this 1944 letter pushing for park creation, Secretary of Interior Harold Ickes emphasized protecting wildlife as a central goal of Everglades National Park:

"The scenic, wildlife and other park resources of the area urgently need better protection from illegal hunting and fires, and from drainage projects to the north of the area which brought about the intrusion of salt water into fresh water

use. I use the word preservationist to refer to early Everglades environmentalists who were interested in protecting Everglades nature from human use. 
supplies, resulting in the destruction of vegetation. The wildlife of the region, which is of extraordinary interest, and includes a number of rare species, is subject to serious depredations if not adequately protected. If the area is adequately patrolled and protected in the future, it would be possible also to conserve the major bird rookeries during the vulnerable nesting season." (NARA IIa)

His words echoed the sentiments of early Everglades preservationists and park proponents like Ernest Coe, a Miami landscape architect, and John H. Baker, President of the National Audubon Society, who also emphasized the "outstanding characteristics" of the Everglades unique plant and animal life (NARA IIb). In fact, the original land deed that transferred land from the State of Florida to the federal government for park establishment states that the Park's purpose is "for wildlife conservation purposes" (NARA IIa).

These early remarks underline that at this historical juncture preservationists were focused on achieving adequate protection for this section of the southern Everglades not the entire Everglades watershed. While water was recognized as important, it was not yet cast as the lifeblood of the ecosystem - despite Marjory Stoneman Douglas' influential reference to the Everglades as a "River of Grass" in her 1947 book (Douglas 1947). Widespread conceptualization of the Park as part of a larger hydrologic province meriting protection was not yet apparent to most Everglades advocates. Instead, early advocates believed protection of the Park itself, in their view an untrammeled natural area, would adequately safeguard the Everglades and its resources (Davis 2011).

In fact, in 1947, the year of the Everglades National Park dedication, the prevailing attitude toward water was that it continued to be an unharnessed force of nature in south Florida that needed to be controlled (not restored) across the landscape for 
the benefit of agriculture, people and nature (Derr 1998, McCally 1999, Hollander 2008, Grunwald 2006, Davis 2011). At the time, water in South Florida was portrayed as the "vicious scourge of mankind" that had to be tamed by technology (Davis 2011, 391 describing its portrayal in the movie, Waters of Destiny.) Moreover, two strong hurricanes struck South Florida in 1947, resulting in widespread and destructive flooding. The aftermath of these storms and over sixty years of struggles attempting to reclaim the soggy Everglades contributed to broad-based support for the US Army Corps of Engineer's Central and Southern Florida flood control project (McCally 1999, Hollander 2008, Grunwald 2006, Davis 2011). The CS\&F was a large-scale federal reclamation project designed to dam, dike, control and channel the waters of the Everglades from the northern reaches of the St. John's River to its southern edge, Florida Bay in order to promote widespread regional agricultural and development. The Corps was viewed as the agency with the financial and institutional resources capable of managing and taming the Everglades for the region's benefit - and government intervention was seen as a welcome necessity (Grunwald 2006, Hollander 2008, Davis 2011). In essence, the Corps became the ultimate Everglades trustee. The Corps represented just the kind of technological expertise south Floridians thought they needed to build a prosperous region. As Davis writes: "[The Corps] projects came to represent a sort of institutional iconography of civilized society's power over environmental forces - in particular, water" $(2011,389)$.

Even Marjory Stoneman Douglas, author and in her later years a tireless Everglades advocate, had confidence in the proposed flood control activities of the US Army Corps of Engineers. As Historian Jack Davis (2011) chronicles in his excellent biography of Douglas, she believed that the Corps' CS\&F flood control project would 
result in better regional water management and enhance the region's well being by delivering water to coastal cities to stem saltwater intrusion, to farms to build more prosperous agriculture and to the Everglades, including the newly established Park. At the time, Douglas and another high-profile Park advocate, Ernest Coe, shared the popular Progressive belief that Everglades National Park could and should co-exist with the growing agricultural district to its north (on more fertile land deemed conducive to profitable farming), because some Everglades reclamation for cultivation and settlement was desirable. Audubon of Florida too supported the CS\&F project.

\section{The Emergence of Water as a Focus for Environmental Advocacy}

While Douglas observed that Everglades National Park's dedication in 1947 marked the beginning of the environmental movement in Florida (Davis 2011), water did not become a central point of environmental advocacy until the 1960s. The 1961-1966 drought brought to light the ill effects of the CS\&F project on the Everglades and Everglades National Park, prompting an outcry by budding Everglades environmentalists (Grunwald 2006). The drought focused attention on the problems of water distribution, and called into question the trusteeship of the U.S. Army Corps of Engineers.

With the implementation of the CS\&F project, south Florida's waters were managed entirely by the U.S. Army Corps of Engineers instead of nature. As Grunwald recounts, the Corps effectively constructed "the most elaborate water control system ever built" $(2007,221)$. The CS\&F project consisted of approximately 2000 miles of levees and canals and a vast armature of spillways, floodgates and pumps (Grunwald 2006, 221). Water that once spilled from the southern lip of Lake Okeechobee and fanned 
across the Everglades in a slow moving sheet was now diverted to the east by canals and released to tide. In addition, this massive water control system changed the ecosystem's natural hydropatterns and connectivity. The Corps had constructed three water conservation areas - vast reservoirs to the west of the Atlantic coastal cities. However, they acted as isolated sumps where water piled up unnaturally rather than healthy interconnected wetlands. Everglades National Park suffered the most. The Park was starved of adequate water in the dry season and inundated with too much water in the wet season (Grunwald 2006, Davis 2011).

Moreover, the Corps viewed the central objectives of the CS\&F project as flood control and economic development and prioritized the delivery of water accordingly (Grunwald 2006). As a result, the Park's water needs took a backseat to the demands of agriculture and the coastal cities, inciting an Everglades water war as different interests began to vie for water. As Davis (2011) has chronicled: "The Army Corps of Engineers and the state's Central and Southern Florida Flood Control District - with an assembly of farmers, real estate investors and businessmen sitting on its governing board - were refusing to share water with the Park." The Corps refused to open the S-12 floodgates beneath the Tamiami Trail roadway to allow water to flow south from the Water Conservation Areas into the Park. The Park was decimated by the drought - its sloughs and solution holes drying out and muck fires burning up the dry ground (Davis 2011). A handful of Florida environmentalists including the Audubon Society (aided by state official Nathaniel Reed, and the research and writing of Wallace Stegner) contested the Corps' logic and actions, and sounded the alarm that Everglades National Park was imperiled by the very agency the public was brought to believe would protect it 
(Grunwald 2006, Davis 2011). Environmentalists no longer trusted the Corps to be a fitful steward of Everglades National Park. At one point Wallace Stegner posed this rhetorical question: would the US Army Corps of Engineers become "the agency that killed the Everglades?” (Grunwald 2006) Instead, environmentalists stepped into the role of Park trustees and advocates.

Thus, environmentalists assumed a more prominent role in defending the Park against the ill effects of drainage and development associated with the CS\&F project. As Grunwald (2007) details, ENGOs, including the Audubon Society, lobbied for more water for the Park and began to scrutinize the Corps' water management decisions. They persuaded Congress to formally investigate the water needs of the park and to pass a water guarantee for the Park. With public support and the help of Governor Kirk and his environmental aide, Nathaniel Reed, they were also able to convince the Corps to open the S-12s floodgates for a week. Moreover, their legislative victory was an important one. It made clear that the Everglades had rights to water. "Congress had declared that the Park was entitled to water because the nation believed that the park was entitled to survive" (Grunwald 2006, 252).

Environmentalists had assumed the role of watchdog and voice for Everglades National Park in the political arena of water distribution. They called attention to deficiencies in the CS\&F project and in the Corps' commitment to protecting Everglades National Park, a nationally acclaimed and federally owned protected area. Yet, at this point in history, their focus remained on the Park and they were not yet the wellorganized advocacy community they would become. They remained a handful of concerned organizations and individuals. 
Environmentalists' focus stayed on water and ensuring its delivery to Everglades National Park during the next key struggle: the battle over the Big Cypress Swamp, a sub-regional watershed feeding into Everglades National Park. In the early 1970s, Miami-Dade County proposed building a massive international airport in this stretch of wild cypress swamp located to the northwest of the Park, touting it as an economic development project that would put Miami on the map (Davis 2011). This "jetport of the future" with six proposed one-mile long runways was projected to attract 50 million passengers a year and to prompt the growth of a city of a half million people around it (Grunwald 2006). Environmentalists including Audubon's Joe Browder and Charles Lee, Sierra Club's Gary Soucie, the Florida Wildlife Federation's Johnny Jones, Art Marshall (father of Everglades ecology) and state official Nathaniel Reed opposed the project (Davis 2011). Browder built alliances with hunters, concerned citizens and the Miccosukee Tribe of Indians - putting together a strong coalition to oppose the project (Russell 2010). Located only six miles upstream from the Park, they strategically argued that the jetport would cut off vital freshwater flows into the northwesterly reaches of the nation's highly valued Everglades National Park and into the 10,000 Islands (Davis 2011). The events leading up to the designation of the Big Cypress National Preserve galvanized the nascent environmental community dedicated to Everglades protection. As Davis (2011) details, Browder persuaded author Marjory Stoneman Douglas to join the cause. In turn, she founded her own environmental organization, Friends of the Everglades, which would soon assume a central advocacy role in Everglades issues. Moreover, in 1969, a group of twenty-one national environmental organizations and one state organization, Florida Audubon Society, came together as the first Everglades 
Coalition - unified in their determination to defend the Big Cypress Swamp against development (Grunwald 2006, Davis 2011). Thus, protecting Everglades National Park and its sustaining water flows emerged as a compelling, strategic and unifying cause for environmentalists working at the local, state and national scales.

Congress passed the Clean Water Act in 1972, setting the stage for the next big battle over Everglades water. Water pollution emerged as the defining issue. In 1988, Dexter Lehtinen, U.S. Attorney in Miami, filed a lawsuit on behalf of the federal government accusing the State of Florida of gross negligence in its enforcement of water pollution laws in the Everglades (United States of America et al. vs. South Florida Water Manager District 1991, Grunwald 2006). The crux of the lawsuit was simple: the State had allowed Everglades water to become very dirty. Lehtinen cited data from FIU scientist, Ron Jones, which showed that phosphorus levels had skyrocketed in this naturally nutrient-poor wetland, and were changing its vegetation patterns (Grunwald 2006). While the lawsuit did not cite the Clean Water Act in the charges it levied against the State of Florida, it built on the growing American awareness of the need for stringent environmental protection, and popular support for clean water. Everglades environmentalists saw the lawsuit as an opportunity to take the sugar industry and the State of Florida to task for polluting the Everglades and imperiling south Florida's waters (Grunwald 2006). Water became an important avenue through which environmentalists could raise questions about the sustainability of sugar production in the Everglades Agricultural Area, and the state's oversight role in this regard. This struggle prompted the formation of what would become one of the most influential Everglades environmental NGOs, the Everglades Foundation, by billionaires Paul Tudor Jones and George Barley 
(Grunwald 2006). Environmentalists waged an epic campaign against the sugar industry, but were unable to dismantle its agro-industrial complex in the Everglades Agricultural Area or its political influence (Grunwald 2006, Hollander 2008, Davis 2011).

The battle over Everglades water quality lent a regional focus to environmental advocacy and prompted environmentalists to shift their attention to the bigger picture: the problems with water delivery and distribution across the Greater Everglades ecosystem. They adopted a more holistic vision of what the Everglades needed to survive, extending their focus beyond the Park to the lands and waters stretching from the Kissimmee Chain of Lakes to Lake Okeechobee to Florida Bay. They were influenced by the ideas of ecosystem ecology promoted by Everglades scientists including Art Marshall, a visionary biologist at the USFWS (Grunwald 2006, Ogden 2008). Drawing on ecosystem ecology, Marshall presented a blueprint for repairing the Everglades ecosystem, and emphasized that the CS\&F flood control project had caused Everglades degradation (Grunwald 2006). Marshall's Plan elevated the importance of water as the unifying link across the Everglades. For Marshall, water was the lifeblood of the Everglades. As Grunwald observed, "It was Marshall who popularized the image of the Everglades ecosystem as a unified organism, connected from head to toe by clean, fresh, slowly flowing water" (2007, 265). Marshall proposed strategies for repairing ecosystem connectivity by removing barriers to the natural sheetflow of water from north to south, starting with the restoration of the Kissimmee River.

As Grunwald (2007) aptly describes, environmentalists were drawn to Marshall's insights, and used his system-wide focus to inform their own positions on how to fix the Everglades. They realized that water was the way to talk about the complex rehabilitation 
of the Everglades and its diverse habitats, especially if the CS\&F project could be revamped to provide water supply for people while repairing water flows for nature. In fact, environmentalists played an important role in elevating Marshall's ideas in the policy and public spheres, acting as important conduits for the transmission of knowledge created by agency scientists (Ogden 2008). They translated his ideas into an Everglades Coalition document entitled Everglades in the $21^{\text {st }}$ Century, and pushed Congress to undertake a comprehensive re-evaluation of the CS\&F project (Grunwald 2006). Congress listened and directed the Corps to conduct this "restudy", where the slogan "get the water right," frequently used to explain the purpose of Everglades restoration, was officially born. The Restudy process led to the design of the Comprehensive Everglades Restoration Project, commonly known as CERP, which Congress authorized in the Water Resources Development Act of 2000. Specifically, the goal of CERP was to rehabilitate the highly engineered landscape of south Florida through 68 restoration projects in order to "get the water right" (Doyle 2008). Concretely this meant reconfiguring Everglades hydrology so that it "mimic[ked] as closely as possible pre-drainage conditions" (SFERTF 2000, 15).

As the series of events detailed above illustrates, ENGOs emerged as important Everglades trustees by identifying the slippages of state agencies, especially the U.S. Army Corps of Engineers, in their ability to "get the water right." In this way, the issue of water helped ENGOs effectively reposition themselves as Everglades trustees organizations that had the expertise to ensure Everglades water quality and resource integrity. 
Yet, even the power of ENGOs as trustees was not totalizing. While struggles over water enabled their rise to trusteeship, and positioned them as important Everglades actors, they still had to work with and through state agencies to achieve their vision for how to improve (restore) the Everglades. ENGOs and their allies recognized the need to be shrewd politics strategists in designing the Comprehensive Everglades Restoration Plan. Despite their misgivings about the Corps trusteeship of the Everglades, ENGOs recognized that it would be nearly impossible to secure the billions of dollars in funding required for Everglades restoration through any other federal agency. Water projects were the bread and butter of the Army Corps of Engineers, an agency known as the "nation's builders" (Clarke and McCool 1996). Thus, ENGOs and other restoration proponents proposed that the Corps, the same agency that had caused so much environmental destruction in the Everglades, take on responsibility for Everglades restoration. For political and budgetary reasons, Everglades restoration would be "a new kind of water project for America" managed by the Corps (Grunwald 2006). Moreover, ENGOs knew any comprehensive restoration effort had to be about water supply as well as repairing the environment. The Governor's Commission on a Sustainable South Florida, a diverse coalition of powerful stakeholders whose consensus-based recommendations formed the basis for CERP design, had emphasized the importance of "expanding the water pie" for all Floridians. Thus, ENGOs knew they had to sell Everglades restoration as a water project for people and nature. 


\section{Water as Capital for ENGOs}

In this section of the paper, I analyze how water functions as an important form of moral, symbolic and social for ENGOs involved in Everglades restoration. First, I examine how the symbolic properties of water lend currency to the advocacy efforts of ENGOs. As a unifying element of the ecosystem, water has emerged as a way for diverse ENGOs to build a clear and compelling case for system-wide Everglades restoration, and establish discursive commonality. Moreover, because clean and abundant water is perceived as a global environmental good that everyone wants and needs, the issue of water helps ENGOs translate the Everglades into a more globally visible landscape worth saving. I close by examining how the intimate materiality of water creates a kind of moral capital for ENGO advocacy efforts based on water.

For Everglades ENGOs, water has strategic value as an advocacy tool because of its material and symbolic properties. Symbolically, water is way of reducing the biological complexity of the Everglades to a comprehensible object of intervention that appeals to a wide audience. As other scholars have observed, when landscapes like the Amazon Rainforest or the Everglades achieve wide acclaim for their ecological importance and their imperilment and become objects of more global advocacy, attention and imagination, they undergo "vivid simplifications that stand in for a far more complex set of places and people, and the ways they interact"' (Slater 2003, 8, see also Hollander 2005). As part of this process a landscape is often recast and represented in simplified terms. Certain aspects of an ecosystem receive attention while others fall to the margins as a society discusses and decides what is worth saving and why. As Hollander explains 
(2005), usually a single idea or very strategic catch phrase is adopted to describe the landscape and make it more politically and socially visible. This simplification also works to guide the symbolic associations people have with that place so that the public sees it as something valuable worth saving. Yet, these discursive reductions are not value-free or apolitical. They deserve attention because they often naturalize certain ways of seeing the landscape by environmentalists and state actors, and reinforce power relations about who has the authority to speak for and manage nature often while obfuscating local meanings, cultural contexts and histories (Braun 2002, Li 2007, Heatherington 2010). By casting Everglades restoration as a water project with the aim of "getting the water right", ENGOs are able to craft a smooth, easily comprehensible narrative about Everglades degradation and how to remedy it. In this way they solidify their trusteeship by translating a messy reality into a compelling "linear narratives of problems, interventions and beneficial results" (Li 2007,4). Yet, this portrayal often glosses over the Everglades rich cultural heritage and human history (Ogden 2011), which is integral to designing effective restoration strategies, and obfuscates other important Everglades ecologies also worth saving, such as the dwindling and imperiled pine rockland forests that are part of the Everglades ecological mosaic (USFWS 1999). In addition, water draws more global attention and public concern to the Everglades because it is global environmental issue that jumps scale and context. As Tracey Heatherington (2010) reminds us, "seeing like an ENGO", requires linking local issues to global environmental concerns and discourses. Heatherington discusses how ENGOs engage in cultural translations and representations of iconic conservation landscapes, in order to make them into more universally comprehensible forms of global 
nature. As Heatherington explains, in the postmodern era this process is central to communicating nature's value to and capturing the attention of far-away cosmopolitan audiences who often support nature protection campaigns. Heatherington describes this action as "seeing like an ENGO," which she suggests "entails a pattern of cultural translation that transcribes local events and debates into stories and visual discourses of global concern" thus ultimately resulting in their simplification and abstraction for strategic gain. By making the story of the Everglades into a story of water, ENGOs can tap into the environmental awareness of millions of people who may not live nearby the Everglades but who understand water as an indispensable yet imperiled global resource in an era of environmental crisis.

Finally, in addition being a kind of symbolic capital that can be used to raise awareness about the Everglades as an imperiled but important ecosystem, water also has a material intimacy that makes people care about it and feel morally inclined to protect it. There is a universal need and desire for water by all people. As Veronica Strang $(2004,4-$ 5) describes, "As the substance that is literally essential to all living organisms, water is experienced and embodied both physically and culturally. The meanings encoded in it are not imposed from a distance, but emerge from an intimate interaction involving ingestion and expulsion, contact and immersion.” Thus, water acts as a kind of strategic moral capital for getting people to care about Everglades restoration and for making political headway because of its intimate material properties. 


\section{Environmentalist Visions for Everglades Restoration}

This section of the paper draws on my fieldwork with Everglades ENGOs and a survey of Everglades environmentalists. In this section, I look at how water both unifies and divides the Everglades ENGO community. Using a survey, I show that Everglades ENGOs "will to improve" remains keenly guided by a hydrologically driven vision for system-wide Everglades restoration, which they believe should be achieved by repairing Everglades water quality and bringing back more natural water flows. This vision lends discursive continuity to their broader advocacy efforts and coalition statements on Everglades restoration. Yet, drawing on my experiences working with two Everglades ENGOs, I demonstrate that the Everglades ENGO community is also a diverse set of actors who have internal differences about the best ways to deliver more clean water to the environment. While speaking with one voice through the Everglades Coalition, they often disagree about project prioritization, project strategy and the proper place for people in the management and restoration of Everglades water resources. Thus, the devil is in the details when it comes to getting the water right.

\section{A Social Survey of the 2011 Everglades Coalition}

ENGOs" "will to improve" (Li 2007) in Everglades restoration continues to be guided by a hydrologically driven vision of ecosystem restoration whose key tenets resemble those of the Art Marshall Plan. Theirs is a vision that foregrounds the importance of water in rehabilitating the Everglades landscape. A survey that I conducted with the 2011 Everglades Coalition illustrates this focus and points to two enduring 
themes for environmentalists: restoring the Greater Everglades ecosystem's water flow and water quality.

As part of a Florida Coastal Everglades LTER research initiative called "Defining Everglades Restoration Success," I worked with my advisor, anthropologist Dr. Laura Ogden, and two senior Everglades scientists, John C. Ogden and Dr. Thomas Van Lent, to design and disseminate an online social survey to the 2011 Everglades Coalition. The purpose of the survey was to elicit how this broader community of Everglades environmentalists values the Everglades and envisions its successful restoration.

The Everglades Coalition is a longstanding "alliance of 53 local, state and national conservation and environmental organizations dedicated to the full restoration of the greater Everglades ecosystem." Its membership includes small (less than 10 full-time staff), locally focused ENGOs like the Loxahatchee River Coalition to national ENGOs like National Wildlife Federation headquartered in Washington DC to big international NGOs (BINGOs) with a global presence such as World Wildlife Fund. Because of its diverse make-up, the Everglades Coalition offered an excellent opportunity to survey the perspectives of environmental organizations of varying scopes and sizes. Moreover, by distributing the survey through the 2011 Everglades Coalition's conference webpage, I was able to reach a much wider audience of ENGO practitioners, advisors and supporters. The annual Everglades Coalition Conference brings together ENGO board members, affiliated scientists, citizen members and government allies to discuss the state of Everglades restoration. Thus, as a gathering place, the Everglades Coalition Conference offered an opportunity to solicit more diverse input about what a restored Everglades looks like and means. I worked with the Everglades Coalition conference co-chairs to 
post an advertisement about and a link to the survey on the 2011 Everglades Coalition's conference homepage. John C. Ogden, a highly regarded and well known Everglades senior scientist and ENGO advisor, wrote the survey's cover letter asking ENGOs and their supporters to participate. Moreover, via email, I targeted specific ENGO staff members who I had worked with as an Everglades policy fellow. I asked them to complete the survey and to pass the survey link on to their colleagues, boards and members. I collected a total of 91 survey responses.

Broadly speaking, the survey results demonstrated that Everglades environmentalists hold a hydrologically driven vision of Everglades restoration. One of the most relevant and illustrative survey questions was: "When you think about a fully restored Everglades, what do you envision?” This question asked respondents to describe their vision for a fully restored Everglades in a couple of sentences, using their own words. I used a word frequency analysis to analyze the 72 responses, and to identify the 45 words respondents most frequently used. A word frequency analysis is a systematic way of highlighting key ideas in survey or interview data. Figure 2 (Wordle image) displays the results of the word frequency analysis. The words that appear in the largest text are those words that were mentioned the most often by environmentalists and lent the most importance. In summary, the words "Everglades", "water", "natural", "flow", "restored" and "quality" were the most prominent. 


\section{Figure 2: Wordle of Environmentalist Responses Describing a Restored Everglades}

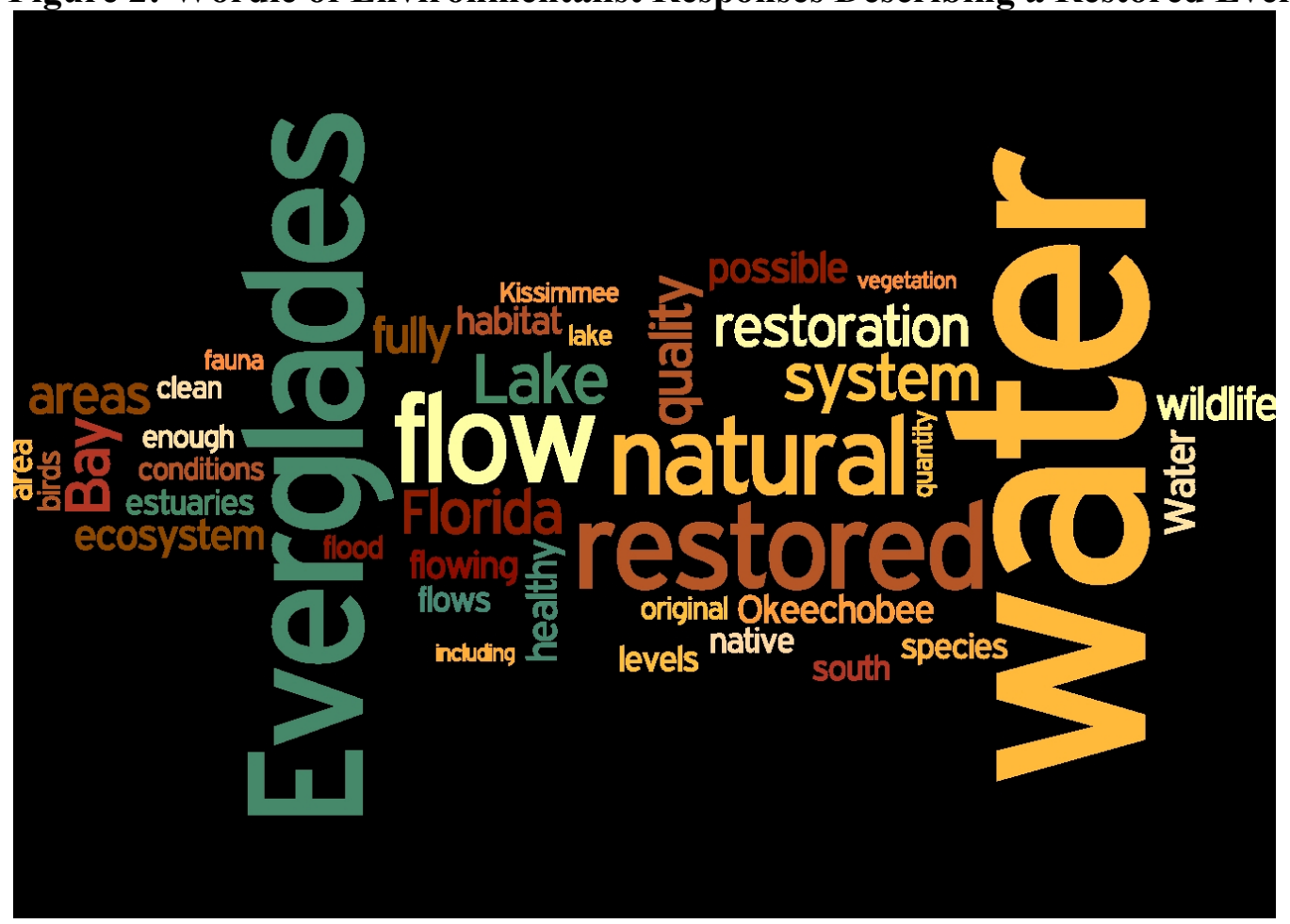

This Wordle image displays the results of a word frequency analysis generated from qualitative data gathered in a 2011 survey of the Everglades Coalition. A word frequency analysis is a systematic way of highlighting key ideas in survey or interview data. The figure displays the words most often mentioned by environmentalists in response to the open-ended survey question: "When you think about a fully restored Everglades, what do you envision?" The largest and boldest words are those that appeared repeatedly in environmentalist responses.

I then conducted an in-depth analysis of the survey responses to put these key words in context (KWIC). I found that approximately $76 \%$ (55 out of the 72 people) of the people who answered this question discussed the importance of restoring water flow across the Everglades ecosystem for the benefit of the environment. A further breakdown of these responses provided insight into the specifics of how environmentalists believed water flow should be restored. Ten people emphasized restoring water flow from Lake Okeechobee or the Everglades to Florida Bay while twenty-two people discussed recreating the natural, unimpeded or sheet flow of water through the Everglades. As one 
environmentalist stated, "[successful Everglades restoration is the] free flow of clean water from the Kissimmee [River] valley through Lake Okeechobee southward in a broad sweep to flow slowly unimpeded under US [highway] 41, then flowing southwestward to Florida Bay. Water inputs must follow seasonal patterns and water to the eastern and western estuaries must flow gradually without heavy surges of fresh water. The rest will follow." This vision parallels the image of a restored Everglades advanced by prominent and well-known Everglades restoration plans and proponents, which draw on the ideas of Art Marshall, and are displayed and discussed at countless Everglades meetings and conferences. In addition, $28 \%$ of the responses to this question (20 people) highlighted the importance of water quality or clean water to a restored Everglades. However, these responses were short on specifics about clean-up methods or water quality benchmarks. Respondents also emphasized bringing back a more "natural" Everglades in contrast to the "unnatural" Everglades of today. For most environmentalists, more natural meant restoring the Everglades to resemble pre-drainage, original or historic hydrological and ecological conditions. Yet environmentalists also acknowledged the limits of this vision, likely because they recognize that over half of the historic Everglades has been lost to development and agricultural production. In response to a separate survey question, the majority of survey respondents (54\%) disagreed with the statement: "The remnant Everglades can be fully returned to its pre-drainage conditions."

What these survey responses illustrate, in part, is a kind of nostalgic orientation by environmentalists toward a historic Everglades where water was clean, and where water flowed freely and slowly across the region's wetlands, tree islands and prairies in one uninterrupted sheet unimpeded by human control. This is emblematic of the notion 
that "if we can just get the water right" (the quintessential slogan of Everglades restoration), then the rest of the ecosystem will follow in its recovery.

\section{The Devil is in the Details: Diverse Environmental NGO Positions on Getting the Water Right}

In practice, how to "get the water right" proves to be a much more complicated matter, in part because water as a material resource is highly contested and its distribution is power-laden (Worster 1985, Strang 2004). In the Everglades, there are constant debates between local people, the federal government, environmental NGOs and economic interests about how to get the water right at restoration project meetings and restoration conferences (my survey outlines the different ideas outdoorsmen and environmentalists hold about effective Everglades restoration, an idea expanded upon in chapter 6). Yet, even within these communities there is fragmentation and debate. As an example, the Everglades ENGO community is diverse and often disagrees internally about the best way "to get the water right." In fact, discussions about water both unify and divide Everglades ENGOs, providing insights into the ways ENGOs strategically work together to achieve ecosystem restoration goals but also remain diverse and divided. As I discussed above, water creates discursive commonality between ENGOs with disparate missions and foci, and enables them to speak with one voice about the broad details of restoration through coalition groups like the Everglades Coalition.

I observed many internal differences among Everglades ENGOs during the two years I worked as an Everglades policy fellow, first for the National Parks Conservation Association and then for the Everglades Foundation. While ENGOs generally supported 
the restoration of the Greater Everglades ecosystem, there were tensions centered on three water-related issues: what projects and Everglades geographies should receive priority, what advocacy strategies were desirable, and what the right role for people in the management and restoration of Everglades water resources should be.

These points of debate were very evident in discussions over the Tamiami Trail restoration project and its broader policy implications. The Tamiami Trail is an historic roadway, completed in 1928, which runs along the northern boundary of Everglades National Park. It is an example of the landscape fragmentation created by Everglades reclamation and development, and is problematic in the scope of Everglades restoration because it blocks adequate freshwater flows into Everglades National Park and Florida Bay. Daniel Beard, the first Superintendent of Everglades National Park, was one of the early scientists to recognize that the Tamiami Trail was an impediment to water flow into the Park. In the 1940s, Beard observed: "With water as the basis for all life in the proposed park, any deflection of flow north of the Tamiami Trail would cause profound ecological changes throughout much of the park area. A drainage canal along the Tamiami Trail does this to some extent at present, but it may be corrected. With water at a premium since drainage operations were undertaken at Lake Okeechobee, control of the cypress and Everglades country north of the Trail is essential" (quoted in Davis 2011, 372). The truth of Beard's observations became apparent during the droughts of the 1960s and 1970s when the Park nearly dried out - engineers needed to find ways to convey more water under the Trail and into the Park. In 1989, Congress called for the reinstatement of freshwater flows to the eastern reaches of the Shark River Slough, requiring the planning of a project to deliver more water to Everglades National Park, 
Modified Water Deliveries, and expanded the existing park boundaries to include this vital watercourse (NPS 2006).

In part, debates over the Tamiami Trail project stem from the fact that ENGOs in the Everglades, like in many other landscapes, stake out terrain based on their expertise and funding, and for the purposes of branding. Specifically, each ENGO has its signature Everglades project(s) that coincide with its mission, and it typically focuses its science and/or advocacy efforts on a specific area of the Everglades. For example, Audubon of Florida has shifted its focus in more recent years to developing scientific and policy expertise about the rehabilitation of Lake Okeechobee and, thus, shifted its focus more towards the Northern Everglades (a more recently defined Everglades region that stretches from the headwaters of the Everglades in the Kissimmee Chain of Lakes to Lake Okeechobee). Moreover, because of its mission, Audubon focuses on restoring water flows across the Everglades but with the intent to advance bird conservation. On its webpage, Audubon discusses how the recovery of certain imperiled bird species will signal successful restoration. Other ENGOs, like the Sanibel-Captiva Conservation Association are focused on more localized issues such as ending harmful water releases from Lake Okeechobee into the Caloosatchee River and estuary, which is in their backyard. The National Parks and Conservation Association (NPCA), on the other hand, in accordance with its mission, ${ }^{5}$ focuses on the health of south Florida's National Parks and, as a result, has developed extensive expertise on the southern Everglades, including the Tamiami Trail project. The Everglades Foundation, as one of the primary funders of Everglades restoration advocacy, takes a more regional and economically oriented 
approach to Everglades restoration. It supports and funds projects across the Greater Everglades Ecosystem with a particular emphasis in recent years on acquiring sugar lands for ecosystem restoration in the Everglades Agricultural Area, conducting studies to demonstrate the economic importance of Everglades restoration, and completing the Tamiami Trail project.

The debates that I witnessed and participated in focused on three central issues. At a broader level within the Everglades ENGO community, ${ }^{6}$ there was debate over the appropriate amount of attention and resources to focus on the southern Everglades and Everglades National Park. While there is a general recognition among Everglades ENGOs that water storage, distribution and delivery need to be repaired across the Greater Everglades ecosystem, there are internal differences over what projects and Everglades geographies should receive priority. While I worked on a 2009 white paper for the Obama Administration outlining Everglades restoration priorities, I received some pushback from other environmentalists who made the case that the my draft white paper was too focused on the southern Everglades and the National Parks. This was not readily apparent to me as I was a newly minted employee of NPCA and had adapted their frame of reference for Everglades restoration. Moreover, I had just starting learn more about other ENGO projects in the Everglades. As another ENGO representative reminded me, the federal interest in the Everglades extended beyond the southern Everglades. She informed me that the Everglades was peppered with other federal lands besides the National Parks, including places like the Loxahatchee National Wildlife Refuge. Another

\footnotetext{
${ }^{5}$ The National Parks Conservation Association's mission is "to protect and enhance America's national parks for present and future generations."
} 
environmental lobbyist insisted that the health of the Caloosahatchee River, one of the estuarine systems imperiled by sporadic freshwater releases to tide from Lake Okeechobee, should receive priority. An advocate representing a local Everglades ENGO wanted to elevate water quality as a priority issue. These comments point to a diverse environmental community where different organizations advocate different priorities for meeting the water needs of the Everglades. In drafting collective ENGO advocacy documents, these priorities and positions have to be negotiated.

Each part of the Everglades has its own constituency of interests, and, as I have just described, ENGOs are important players within these constituencies. At the level of the Tamiami Trail project several ENGOs are more deeply involved in the issues than others. These include: the Sierra Club, Audubon, the National Parks Conservation Association, and the Everglades Foundation. In recent years, as the project has progressed, they have led the discussions about the amount of bridging that constitutes an acceptable end-goal, and how to balance the need for greater water flows into Shark River Slough with people and their claims to the East Everglades. NPCA is one of the ENGOs that have been most closely involved in this project since its inception in 1989. NPCA has closely followed the issues, built up expertise around them and written comment letters on the Tamiami Trail project on behalf of a larger ENGO contingent. Because of its history, it was expected that NPCA would write a comment letter to the National Park Service on a 2010 proposed plan for 6.5 miles of additional Tamiami Trail bridging by the Department of the Interior (for an overview of the plan see NPS 2010).

\footnotetext{
${ }^{6}$ It should be noted that I dealt more closely with two coalitions of ENGOs, the Everglades Coalition and the Everglades Advisory Committee.
} 
A good deal of discussion at the time of NPCA's initial project scoping letter (which I authored) and into my tenure with the Everglades Foundation centered on strategy: how to frame the additional bridging to garner broad based support for it, and how to present it to Congress to ensure its funding. The Sierra Club came to the table insisting that we call the project a "skyway." This term originated from a Sierra-led campaign in the 2000s that pushed for an 11-mile bridge that would span the entire Shark River Slough, which Sierra branded the "Skyway." Sierra created compelling graphics of what the skyway would look like and launched an impressive campaign to make it a reality (while carving out an important advocacy position and name recognition for itself on this issue). However, opposition by the Miccosukee Tribe of Indians of Florida and high project costs complicated the realization of the Skyway at the regional and federal levels. Yet, Sierra still believed in the eventual construction of the Skyway, and they called for this option in their initial round of scoping comments to the National Park Service regarding additional bridging of the Tamiami Trail. For other organizations, the Skyway - while once a salient idea and an attractive concept that would provide maximum environmental benefits to the Park - was no longer a strategic way of branding the project. Instead, the skyway had come to symbolize an idea that had lost traction, was too expensive in the current political climate and would be opposed by key decisionmakers. As one ENGO director told me: "Don't use the word Skyway." Instead, the Tamiami Trail project was rebranded as the critical next step in delivering vital water flows to Everglades National Park and restoring the southern Everglades.

In many ways, the Everglades ENGO community disagrees about the specifics of what a natural and restored Everglades looks like - a debate that readily spilled over into 
the Tamiami Trail project. Part of this debates centers on defining the proper role for humans (culture) in Everglades restoration. As Veronica Strang (2004) reminds us, the common perception is that water that is closer to human management and intervention is considered more adulterated and impure. This assumption certainly carries over into defining ENGO positions on Everglades restoration. Everglades ENGOs can be categorized using a three-part typology. There are: 1) pro-wilderness ENGOs who believe that people do not belong in the Everglades except as tourists, scientists and visitors and are motivated by nostalgia for a primordial Everglades nature where the flow of water is unimpeded by human presence or control; 2) more moderate ENGOs who may compromise on a balance between nature/culture, depending on the issue, but who continue to rely on expert science to determine the proper place for people in Everglades management and the right way to re-engineer Everglades waters; and 3) ENGOs who are embracing the idea of the Everglades as a sociocultural landscape and working to incorporate local people and their knowledge back into Everglades restoration and management. Sierra Club falls into the first category. NPCA, Audubon and the Everglades Foundation can be classified as part of the second category, while The Nature Conservancy fits the third category.

One of the defining issues in discussion about the 2010 Tamiami Trail bridging project was if commercial and private airboat operators and their four properties south of the roadway would act as obstacles to realizing greater water flows into the Park. In this debate, the Sierra Club firmly viewed the Tamiami Trail project as purely a water project designed to deliver more water into a wilderness eligible part of Everglades National Park. Sierra took the position that commercial airboat operators (who make their 
livelihood from the Everglades) should not be allowed to remain in the Tamiami Trail project footprint and that recreational and commercial airboats should be banned from the East Everglades. In a 2009 comment letter, Sierra wrote, "left in place these operations would remain as large scale impediments to the historic natural flows of water in Shark River Slough" (Sierra Club 2009, 2). Moreover, as a project public comment summary document explained: "Sierra Club argues that neither these facilities, nor airboats in general, belong in the East Everglades Expansion Area. Instead, they would like to see this area of the Park officially designated as wilderness and opened for non-motorized watercraft. The Sierra Club also argues that the commercial airboat facilities will impede the flow of water south under the proposed bridges" (URS 2009).

On the other hand, NPCA chose to question whether the commercial airboat operations should be allowed to remain in their current locations due to the increased project costs associated with providing bridge down ramps and flood protection to these facilities. NPCA chose to ask: would these mitigation measures constitute an appropriate and acceptable cost to the nation?. Considering culture but still leaning more towards the side of unadulterated water flows, NPCA made the argument that these businesses should be purchased by the Park and consolidated to decrease their footprint and their potential interference with the Tamiami Trail project's anticipated water deliveries to the Park.

In 2010, when I helped to write the scoping comment letter on behalf of NPCA and other environmental organizations detailing the environmental community's position on Tamiami Trail bridging, the Sierra Club opted to write a separate letter in which to clearly articulate their stronger views on eliminating all airboats from the East 
Everglades, and their concerns about the effects of the airboat concessionaires on water flow.

Other Everglades ENGOs like the The Nature Conservancy and the Legacy Institute for Nature and Culture are rethinking the place for people in Everglades nature and moving forward with innovative new projects that eschew highly bureaucratic technical ecosystem restoration and embrace the role of local people as Everglades stewards. TNC and LINC have been influential backers of the Headwaters National Wildlife Refuge project in the Northern Everglades, which seeks to protect parts of the watershed north and west of Lake Okeechobee using public land acquisition and private conservation easements with ranchers. TNC has worked with these Everglades ranchers to broker some of its own conservation easements and readily acknowledges the integral role ranchers play in protecting Everglades waters. TNC, LINC and other project partners embrace the idea that the Northern Everglades is a slice of Florida's important natural and cultural heritage.

\section{Conclusion}

In this chapter, I examined the hydropolitics of environmentalism in the Florida Everglades. First, I examined the rise of ENGOs as influential Everglades trustees and I documented how water - which has become the defining element of Everglades restoration - has created a strategic opening for ENGOs to assume a position of environmental "trusteeship" (Li 2007) in the Florida Everglades. I also documented how the material and symbolic properties of water make it a compelling object for environmental advocacy, and how water has created discursive commonality among 
diverse ENGOs. Finally, I showed that while water has become an important advocacy tool for Everglades ENGOs, the Everglades ENGO community remains a heterogeneous group of organizations with varied identities and priorities - both unified and divided by the issue of water. I refer to the ways water enables and constrains, and unifies and divides ENGOs in Everglades environmental politics as hydropolitics. 


\section{REFERENCES}

Agrawal, Arun, and Clark C Gibson

2001 Communities and the Environment: Ethnicity, Gender, and the State in

Community-based Conservation. New Brunswick, N.J.: Rutgers University Press.

Braun, Bruce

2002 The Intemperate Rainforest: Nature, Culture, and Power on Canada's West

Coast. Minneapolis: University of Minnesota Press.

Brosius, J. Peter

1999 "Green Dots, Pink Hearts, Displacing Politics from the Malaysian Rain Forest." American Anthropologist 101.

Clarke Jeanne N., and Daniel C. McCool

1996 Staking Out the Terrain: Power and Performance among Natural Resource Agencies. Albany: State University of New York Press.

Davis, Jack E

2011 An Everglades Providence: Marjory Stoneman Douglas and the American

Environmental Century. Athens, GA: University of Georgia Press.

Derr, Mark

1998 Some Kind of Paradise: A Chronicle of Man and the Land in Florida.

Gainesville, FL: University Press of Florida.

Douglas, Marjory Stoneman

1947 The Everglades: River of Grass. $60^{\text {th }}$ Anniversary edition with update by Michael Grunwald. Sarasota, FL: Pineapple Press, 2007.

Doyle, Mary

2008 "The Everglades." In Large-scale Ecosystem Restoration: Five case studies from the United States. Mary Doyle and Cynthia Drew eds. Pp. 1-2. Washington, DC: Island Press.

Escobar, Arturo

1995 Encountering Development. Princeton, NJ: Princeton University Press.

Foucault, Michel

2000a [1982]. "The Subject and Power." In Power: Essential Works of Foucault: 19541984. James D. Faubion ed., and Robert Hurley and others, trans. New York: The New Press. 
2000b. [1991] “Governmentality.” In Power: Essential Works of Foucault: 1954-1984. James D. Faubion ed., and Robert Hurley and others, trans. Pp. 326 - 348. New York: The New Press.

Grunwald, Michael

2006 The Swamp: The Everglades, Florida and the Politics of Paradise. New York: Simon and Schuster.

Heatherington, Tracey

2010 Wild Sardinia: Indigeneity and the Global Dreamtimes of Environmentalism. Seattle, WA: University of Washington.

Hegewald, Jeffrey 2010 Miccosukees and the Tamiami Trail Bridge: Examining the Tribe's Attempts to Sink the Modified Waters Delivery Project. University of Miami School of Law.

Hollander, Gail

2005 The Material and Symbolic Role of the Everglades in U.S. National Politics. Political Geography 24:449-475.

2008. Raising Cane in the 'Glades: The Global Sugar Trade and the Transformation of Florida. Chicago: The University of Chicago Press.

\section{Li, Tania Murray}

2007 The Will to Improve: Governmentality, Development and the Practice of Politics. Durham, NC: Duke University Press.

McCally, David

1999 The Everglades: An Environmental History. Gainesville, FL: University of Florida Press.

Milton, Kay

1996 Environmentalism and Cultural Theory: Exploring the role of anthropology in environmental discourse. New York: Routledge.

Mitchell, Timothy

2002 Rule of Experts. Berkeley, CA: University of California Press.

National Archives and Records Administration II (NARA)

IIa Assorted Letters and Papers. RG 79, NPS Central Classified Files, Subseries 2 (PI 166 7.ZZ1): Box 900 - Everglades - General.

IIb Ernest Coe to the Honorable Ed Pou, Chairman Committee of Rules, House of Representatives, February 1933. RG 79, NPS Central Classified Files, Subseries 2 (PI 166 7.ZZ1): Box 903 - 120 - Legislation. 
Committee on Independent Scientific Review of Everglades Restoration Progress, National Research Council, National Academy of Sciences (NAS)

2010 Progress toward restoring the Everglades: The third biennial review. Washington, DC: National Academies Press.

U.S. National Park Service (NPS).

2006 East Everglades Expansion Area. Everglades National Park General Management Plan Newsletter 3. June.

2010 Everglades National Park Tamiami Trail Modifications: Next Steps.

Environmental Impact Statement.

Ogden, Laura A.

2008 The Everglades Ecosystem and the Politics of Nature. American Anthropologist $110(1): 21-32$.

2011 Swamplife: People, Gators and Mangroves Entangled in the Everglades.

Minneapolis: University of Minnesota Press.

Orlove, Ben and Steven Caton

2010 Water Sustainability: Anthropological Approaches and Prospects. Annual

Review of Anthropology 39:401-415.

Runte, Alfred

1979 National Parks: the American Experience. Lincoln: University of Nebraska Press.

Sayre, Nathan F.

2005 Ranching, Endangered Species and Urbanization in the Southwest: Species of Capital. Tucson, AZ: University of Arizona Press.

South Florida Ecosystem Restoration Task Force (SFERTF)

2000 Coordinating Success: Strategy for Restoration of the South Florida Ecosystem. Miami: South Florida Ecosystem Restoration Task Force

Sierra Club

2009 Addendum to Comments on Tamiami Trail Next Steps and the Restoration of

Shark River Slough. June 29.

Slater, Candace

2003 Entangled Edens: Visions of the Amazon. Berkeley, CA: University of California Press.

Strang, Veronica

2004 The Meaning of Water. New York, NY: Berg.

United States of America, et al. v. South Florida Water Management District

1991 Settlement Agreement, 26 July 1991. Case No. 88-1886-CIV-Hoeveler 


\section{URS Corporation}

2009 Public Scoping Report. Everglades National Park Tamiami Trail Modifications: Next Steps.

U.S. Fish and Wildlife Service (USFWS)

1999 Pine Rocklands. In Multi-Species Recovery Plan for South Florida: Ecological Communities. Bethesda, MD: U.S. Fish and Wildlife Service Reference Service.

Worster, Donald

1985 Rivers of Empire: Water, Aridity and the Growth of the American West. New York, NY: Oxford University Press. 


\section{Chapter 3: A Hunter's Landscape ${ }^{1}$ - Place, Property and Practices in the Big Cypress Region}

\section{Introduction}

One of the most interesting moments during my fieldwork in the Florida

Everglades came during a mild winter weekend in January 2012. One of the outdoorsmen who was a key contact in my research, Terry, invited my husband and I to spend the night at his backcountry camp in the Big Cypress National Preserve. On the ride out to camp I struck up a conversation with his friend, Kyle, who owns the camp. Kyle - lanky and good-natured with sparkling green eyes - is a life-long hunter who spent his teenage years in the "cypress county." Kyle recounted his life history in the Big Cypress region. His backcountry camp is one of the approximately 100 camps that remains from national preserve creation (NPS 2000, 121). His camp spans three generations of hunters and two eras of cypress land stewardship, linking the hunter's landscape that was characteristic of the Big Cypress region to the contemporary conservation landscape that is the Big

\section{Cypress National Preserve.}

Kyle spoke about his formative experiences growing up in the woods and described his mentor, Dan, a baseball coach from Homestead, Florida. Dan was the original camp owner of Kyle's backcountry camp. Dan showed Kyle the ways of cypress

\footnotetext{
${ }^{1}$ I am indebted to Laura Ogden (2011) for this term. Ogden uses the term, "hunter's landscape" in her book, Swamplife. She invokes this term as a framing device to illustrate how the Everglades landscape that alligator hunters knew and understood emerged from a particular constellation of human/non-human relations, and was one of the many socio-natural entanglements arising from actors making territorial claims to the Everglades. Specifically, Ogden writes “The hunter's landscape is a set of relations among humans and non humans that were shaped, in part, by the cultural practices and economic incentives of rural hunting in south Florida" $(2011,26)$. I use this term to signal how the Big Cypress region emerges from particular relations between hunters and its landscape - shaped by the modern practices of hunting and the evolving uses of the Big Cypress as a meaningful space apart from modern life. As Ogden makes clear, the hunter's landscape is one way of knowing and seeing this place, which is entangled with other ways of seeing and staking claim to the Everglades.
} 
country, including how to drive a swamp buggy. Kyle also told me how he learned some key life lessons about hard work, a can-do attitude and self-reliance from Dan, which he later shared with his own son. Kyle described how he built his modest swamp buggy, a high-riding vehicle, in his backyard in Homestead, FL; and he listed off the countless weekends he had spent in the woods maintaining his backcountry camp. What struck me most during our two-day trip was the obvious love of the land Kyle and Terry shared. Their joy and delight was apparent when we stopped to look at a dazzling and gigantic cigar orchid in full bloom to the side of the trail, and as we contemplated the wooden cypress ties of an old tram road once used for logging but now hidden from view by muhly grass. Later, in camp, they swapped stories about national preserve management, and, while sitting around the campfire they shared some of their funny and touching cypress country stories from over the years. Their backcountry camp emerged through these stories as a jumping off point for hunting trips, a site for memorable moments with friends and family and a place where larger-than-life swamp stories about elusive game and woods mischief are told and retold. As we listened and laughed in the firelight, I thought about how the landscape of the Big Cypress and this camp, in the words of place theorist Edward Casey, "gather" memories, family moments, the beauties, joys and sorrows of the human condition, history and distinctive sensory experiences for outdoorsmen.

I have often reflected upon my visit to camp that day and what it says about the broader sociohistorical ties of outdoorsmen to the Big Cypress region. It is clear to me that this camp, like so many others, holds an important social resonance and meaning for south Florida's outdoorsmen. Like other camps, it has helped its owners and guests 
maintain a sense of self and of community, and a strong connection to the Everglades, within a rapidly urbanizing southern Florida where access to open space and wild lands continues to decline. In this way, this backcountry camp provides a window into the storied place that the Big Cypress backcountry is - a place that gathers and reverberates with tales of community, hardship, survival, and meaning for outdoorsmen.

Indeed, place has a physicality or materiality to it but it is also an idea about how the world is ordered and what that ordering means. As Casey (1996) describes, place is a complex configuration of objects held together in a particular way. Because of its historic ecology and unique property relations, South Florida's Big Cypress region became a particular kind of place for white outdoorsmen. For them, cypress country evolved into a complex configuration of humans, animals, tree islands, muddy water and swamp machines best described as a hunter's landscape and characterized by a particular set of landscape practices and social relations. It is important to understand the Big Cypress region as a hunter's landscape in order to understand how this landscape was used, valued and known by one group of local people before the creation of the Big Cypress National Preserve in 1974. In this chapter, I describe the property relations and local ecology that enabled this hunter's landscape to develop from the 1930s on, and I detail how these conditions shaped outdoorsmen's ways of being in and moving through the cypress swamp. My descriptive overview shows how, in this context, hunting must be understood as part of broader constellation of practices and social relations rather than the mere act of killing animals. Moreover, I illustrate how outdoorsmen's landscape practices gave rise to a lived and embodied sense of place, and how outdoorsmen's identities and lives came to be emplaced in this landscape. Yet, I also detail how this hunter's landscape 
began to change in the late 1960s as real estate speculation and regional development projects accelerated - shifts that culminated in a proposal to construct an international jetport in Big Cypress region, which would forever change the politics of place.

Chapter 3 sheds light on outdoorsmen's ways of knowing the cypress country, and on their nostalgia for a mythologized past, ${ }^{2}$ that bleeds into contemporary debates about Big Cypress National Preserve management. The present chapter also illuminates how many outdoorsmen's understandings of and ties to cypress country are different from those of other actors such as environmentalists, scientists, NPS managers and tourists who also make claims to the Big Cypress National Preserve today. Finally, this chapter illustrates how the creation of the Big Cypress National Preserve fits into the region's broader historical and political economic trajectory as a project made possible by a coalition of hunters and environmentalists, and designed to protect much of the Big Cypress Swamp from widespread development.

\section{Cypress Country: An Overview}

The Big Cypress Swamp, an almost otherworldly habitat mosaic of cypress strands, pine islands and marl prairies, sits at a slightly higher elevation than the Everglades ridge and slough system to the south (Tebeau 1977). Although not technically part of the "true" Everglades, local people considered the Big Cypress Swamp, which lies

\footnotetext{
${ }^{2}$ As I explain below, outdoorsmen often espouse nostalgia for the freedom that the pre-1970s cypress country afforded. Yet, outdoorsmen's nostalgia obfuscates the larger development trends that were transforming the region and collapses them into a story tinged with bitterness about the injustices of National Preserve creation. Outdoorsmen don't always recognize (or choose to obfuscate) how the landscape would likely have changed under these regional development pressures and further eroded their way of life, without National Park Service land protection. Now, outdoorsmen are facing a different politics of place defined by the bureaucratic and documentary realities of National Park Service nature (as I discuss in Chapter 4).
} 
to the west of the Everglades' sawgrass prairies, to be a distinctive sub-region of the glades landscape. Within the glades, they used a folk taxonomy to distinguish between the sawgrass - the expansive sawgrass marshes of the Everglades punctuated by tree islands - and the cypress - the forested wetlands of the Big Cypress Swamp. Locals still refer to trips to the cypress as "going to the woods" because of the forested nature of its waterscape. One of the defining features of the Big Cypress Swamp, in contrast to the grassy Everglades, is its patchwork of pineland forests, cypress strands and cypress domes (Tebeau 1977).

Much like the pre-Park Everglades (Ogden 2011), the Big Cypress Swamp was a hunter's landscape too. My interviews reveal that commercial, subsistence and recreational hunting practices shaped the Big Cypress region, and that the landscape, in turn, shaped hunter's sense of self and sense of place. In the early years of frontier settlement, glades families depended on this landscape for their survival, harvesting game for subsistence and as an important source of cash income (Tebeau 1977, Ogden 2011). With the completion of the Tamiami Trail roadway in 1928, this once-isolated place became more accessible to coastal and rural Floridians. Following the creation of Everglades National Park in 1947, cypress country became a refuge for alligator hunters and other white hunters who wanted to continue living off the land (Tebeau 1977, Russell

\footnotetext{
${ }^{3}$ Seminole peoples and early white settlers hunted and fished the productive lands and waters of the southwestern Everglades and Big Cypress Swamp, spending extended periods of time in the backcountry. For rural glades people, hunting was one of the most important sources of supplemental income (Ogden 2011). As cultural anthropologist Laura Ogden has extensively documented, the commercial hunting of alligators for their hides was an important livelihood strategy in early gladeland communities (Simmons and Ogden 1998, Ogden 2011). As Ogden has documented, a distinctive part of glades culture in south Florida grew up around the practice of hunting, which helped put food on the table for hard-pressed glades families (Ogden 2011). Hunting parties stayed out in the backcountry for weeks on end, walking or poling canoes or narrow glades skiffs across miles of open marsh and mangrove swamps, and camping on hammocks.
} 
2007, Blythe 2012). Many hunters lived in or frequented the rural town called Pinecrest, situated off the beaten path amongst the cypress strands adjacent to the Loop Road (Tebeau 1977, Russell 2007, Blythe 2012).

From about the 1930s on, the Big Cypress Swamp was home to a distinct form of rural hunting culture characterized by evolving practices including the construction of backcountry camps, and the use of homemade swamp buggies and airboats for travel across the rocky, uneven and mucky terrain. My interviews with outdoorsmen revealed stories about hunters from coastal suburbs and towns like Miami Gardens and rural enclaves like Labelle, Florida who set up backcountry hunting camps - or simple shelters- that were sometimes makeshift, sometimes permanent on the higher ground afforded by hammocks and pinelands across this landscape to serve as anchors points for hunting and exploration. These camps were typically accessible via foot, swamp buggy or airboat. There were hundreds of these camps located throughout the swamp by the 1970s (Duever 1986).

The founding and construction of these backcountry camps marked an important era in the history of the southern Everglades. It was a time when the cypress country was open and wild, and had a distinct set of informal property relations that allowed glades hunters' to more freely access and travel across this landscape.

\section{Property Relations and Ecology in Big Cypress Country}

Through the 1950s, cypress country was a remote, wild and largely undeveloped resource frontier controlled by absentee landowners and corporations whose lack of strict oversight gave rise to unique and informal property relations (Tebeau 1977, interview 
May 12, 2011; interview September 21, 2011; interview January 21, 2012). In the early $20^{\text {th }}$ century, a few large landholders held formal title to the majority of land in "the cypress", as it was known in local shorthand. Beginning in the 1920s, the influential New York businessman, Barron Collier, owned and controlled the largest amount of land in the Big Cypress region (Tebeau 1977). Collier bought land in south Florida as an investment; he was keenly interested in developing the region's economic potential (Tebeau 1977). Timber, land and railroad companies were the other large landholders in cypress country, having amassed the land rights to former swamp-and-overflow lands from their previous owners (Tebeau 1977). Homesteaders, other private landowners and the State of Florida owned the remaining fraction of land. As Charlton Tebeau (1977, 8385) has documented, as of 1926 Barron Collier held legal title to over 900,000 acres in cypress country, making him the owner of over $90 \%$ of the land located in the newly created Collier County.

The fate of cypress country became deeply intertwined with Collier's actions and intentions. Yet, Collier was an absentee landowner. He hired engineer David Graham Copeland and other local people to manage his properties and oversee his construction activities in south Florida (Tebeau 1977). In addition to operating its own sizable cattle ranch, the Collier Company leased grazing rights on many of its land sections to local ranchers, who ran herds of half-wild scrub cows on them (Interview September 21, 2011; Interview January 21, 2012). Collier's cattle leases, designed to bring in revenue to offset his property taxes, covered vast expanses of the cypress (Tebeau 1977). Ranching families, like the Brown family near Immokalee, leased grazing rights from the Colliers 
while timber companies owned and operated sawmills in and around Collier's lands (Tebeau 1977, interview April 13, 2011).

These early $20^{\text {th }}$ century land ownership patterns produced a mosaic of working lands: open-range cattle ranching, truck farming by homesteaders and companies on fertile marl prairies, and logging. As one fifth-generation Floridian, whose grandparents worked in a Big Cypress logging camp, put it: "Those lands were rode hard" (interview, April 13, 2011). Another long-time outdoorsman, who father was an Everglades land surveyor, explained in an interview (September 21, 2011):

And a lot of the prairies were farmed, particularly for tomatoes. There was, you know, a lot of use out there. And people brought heavy equipment in, bulldozers and tractors, and they built the old locomotive trams in order to get in [and harvest timber]. C. J. Jones, you know, and the Turners, they built those old railroad lines into the Cypress in order to get the timber out. There were lots of impacts out there over the years and a lot of use. They ran cattle there were, you know, some pretty good-sized cattle operations there at one time.

Yet, the Collier Company and other absentee landowners couldn't actively use or control all of their immense acreage. Outside of the pockets of working lands described above were vast areas of undeveloped, unregulated and unfenced wild land. Thus, a kind of rural territoriality came to define cypress country, where peoples' movements across and claims to place (land) were structured more by kinship or friendship and physical endurance than by law. In many instances, a handshake would suffice to secure land access rights.

For example, the Browns, a pioneering 'glades family who had operated a lucrative trading post near Immokalee, Florida, subleased parts of their Collier grazing 
lease to local people interested in hunting. In one interview, a native Floridian and hunter from Parrish, Florida, recalled how his father established a "cypress swamp camp" on land that he leased from the Brown family in a place locals called Brown's pasture (located north of what is today Alligator Alley). My informant further explained that his father first hunted the "Glades with his relatives from LaBelle ("he had family there") and then later returned to lease a piece of ground from the Brown family (Interview, January $21,2011)$. Thus, the Browns anchored one of the informal networks of social relations that facilitated hunting.

For rural people coming to cypress country from the north, Burdine's Ranch outside of Immokalee served as another important access point. The ranch's fenced boundaries gave way to wide open cypress country to its south and east. An outdoorsmen whose father built an early backcountry camp south of Burdine's Ranch explained the important role it played:

RG: In the old days how would you access [your camp], before Alligator Alley was built?

Josh: It was just south and a little bit east of Immokalee. It was the Carson Ranch to start with and then Burdines bought it. Then it became something else. When we were using it, it was Burdine's. Some of the old timers would still say the Carson ranch. [Outdoorsmen] would launch their buggy there in the ranch and then go along the fence to the last gate and veer off to the south or east. (Interview, January 21, 2011)

Josh's remarks and an interview with his father, Mason, illustrate how outdoorsmen brokered verbal access agreements with the Burdine's, and how Burdine's granted outdoorsmen permission to leave their swamp buggies parked at the ranch. 
Rebecca: So when you would go through Burdine's Ranch you would come down through Immokalee?

Mason: Come south on [Florida] 29 and turn left ten or twelve miles out there and there's a road that goes to the east...I don't know what the number of that road is. We'd go in there, hook up and then go through Burdine's ranch, working our way southeast until we got all the way to camp.

Rebecca: Burdines didn't care that you drove through their land? You had an agreement with them or how did those things work back then?

Josh: As far as I knew, it was a verbal agreement.

Mason: Uh, it was happening when I came along and it just kept on happening. There was a certain area you could park. And that road [into the cypress] serviced other people down there that had land. The Browns mainly. [Burdine's] let people park - there was always ten or twelve buggies there... (Interview, January 21, 2011)

The above interview excerpts demonstrate the informality of land access agreements and underline how coming and goings in the cypress were often structured by who you knew. In explaining why an outdoorsmen visited or used a certain 'Glades geography in the cypress, the refrains "he knew some people" or "he had family there" were commonly invoked during my interviews.

In fact, early accounts and oral histories I collected about hunting and exploring the cypress country downplayed the role of formal property relations in controlling land access. Instead, outdoorsmen highlighted how they were drawn to an area by family or friends and by the freedom to move into and out of the woods largely unrestricted, especially in contrast to other parts of Florida. One outdoorsmen now in his 80s who has 
spent his life exploring, hunting and making a living in the 'glades summed up the area's historical attraction in the following way: "See, back then, you could just go out and build a camp anywhere" (Interview, September 21, 2011). Another hunter described cypress country as wild place where you could do what you wanted as long as you didn't cause trouble on lands that were widely recognized as off-limits, or infringe on other hunters and their camps (Interview, Dec. 7, 2011). While most of the lands in cypress country were privately owned, local people treated them like a commons (interview, March 22, 2012).

The informality of property relations in the early days of the cypress lent the landscape a feeling of freedom and wildness that outdoorsmen often invoke today when they describe what cypress country was like before the Big Cypress National Preserve was created. As one outdoorsman explained:

And we were fortunate here in Collier County because the Collier family that owned most of the county, they were very generous in that they - they didn't want you on their ranch or where they were growing crops and stuff, but they were - they just let people go on their land for many, many years and hunt and fish and actually build structures, you know, on the land, and it was that way up until of course the Big Cypress [Preserve] came into being, and so a lot of that former Collier land no longer belonged to them, and so things changed. (Interview, Sept. 21, 2011)

He continued:

It was that freedom to just go - and you could go anywhere you wanted, any time you wanted. And a lot of people - that meant a lot to people, you know, there weren't the restrictions that you might have in central Florida [with] a lot of private property, a lot 
of ranches and farms. Here, you had thousands, hundreds and thousands of acres open. You know, Interstate 75, Alligator Alley, wasn't there, it was all one piece, you could get in the airboat and go all the way north, you know....And you could go for days and not see another person. But there were a lot more people out there, as I remember, than there are today. A lot of 'em have died off - the oldtimers. And a lot of people got discouraged and just don't come there anymore because of all the rules and the lack of freedom, you know. And I think that's what a lot of us miss more than anything, is that freedom just to self-regulate and self-rule and just go when you wanted, where you wanted, you know. (Interview, Sept. 21, 2011)

However, as I show later in this chapter, these sentiments can be a form of nostalgia that elides the way capitalist forces of development were transforming south Florida and cypress country beginning in the late 1960s.

\section{Landscape Practices in Big Cypress County: The Emergence of a Hunter's}

\section{Landscape}

The informal property relations that characterized early cypress country, and the open access to land they permitted, fueled the development of a footloose style of backcountry exploration and hunting in the Big Cypress region. However, only those skilled enough, resilient enough, and tough enough were able to navigate the watery and difficult terrain. Early outdoorsmen from across Florida were drawn to the cypress by its abundant game, and the freedom to explore and hunt its vast areas of undeveloped wild 
land, ${ }^{4}$ especially after the completion of the Tamiami Trail roadway made this region

more accessible.

Cal Stone, a Miami electrician and one of the better-known outdoorsmen from

cypress country, would use every spare moment that he could to walk the 'glades. In his

book, 40 Years in the Everglades, Stone describes his recreational ritual: his wife would

drive him out from their home in Miami and drop him off along the Loop Road, a dirt

path that curved south into the cypress country from the Tamiami Trail, the cross-

Everglades roadway completed in 1928. From here, he would walk into the swamp to

explore, as he describes:

All during the 30s, I explored the land south of

Loop Road toward the mangrove country and into

the tidal saltwater marsh at the southern tip of the

peninsula. I explored this area on each trip. Every

weekend or holiday or every time I could go out

there, I would plan to go in a different direction.

Each trip was basically south southeast or southwest

but I always changed my course by a mile or

so.... Throughout the early and mid-30s, I made

many trips during the different parts of the year and

never saw another person once I had left the

Tamiami Trail and entered the woods, not even any

trails. Of course, there were good reasons for not

seeing anyone else. Florida was not densely

populated then. There were no swamp buggies to

travel over the terrain so there was no easy way to

get very far into the true swamp. The only way a

man could get very far from the road was to walk.

\footnotetext{
${ }^{4}$ Florida remained an open-range state until 1949 (Bucuvalas, Bulger and Kennedy 1994, 41) . From the oral histories I conducted with multi-generational outdoorsmen, it is clear that once people starting fencing off their private property, the land available for hunting became far more limited in central and northern Florida. People could no longer simply walk out and hunt where they wished (or had previously hunted) because people began to cordon off their private ranches, farms, groves and landholdings. Outdoorsmen either had to secure access to hunt on privately owned lands through familial ties or friendships, or to seek out unrestricted areas like the cypress country to the south. The fact that the cypress country had a less regulated property regime was one of the main reasons it attracted outdoorsmen from all over Florida; they were drawn out of necessity and curiosity.
} 
You had to carry all your equipment and supplies

in.... You could scratch out a well for water but that

was about all the land offered... (Stone 1979, 25)

Cal Stone's account underscores the open access to the cypress country, if you had the transportation and the will to get out there.

Outdoorsmen first came to cypress in larger numbers in the 1940s as Florida's population began to grow post-WWII, and the open-range drew to a close. Many outdoorsmen were initially attracted to the cypress through the State of Florida's Tick Eradication Program. ${ }^{5}$ One outdoorsmen I interviewed from the rural community of Parrish, Florida, explained that his father, Jim, first visited the cypress country as a participant in the Tick Eradication campaign. After his initial visit to the cypress country, Jim returned to central Florida to hunt near Gulf Hammock. However, once the State acquired the Gulf Hammock, and placed limits camping, Jim travelled back south drawn by "the freedom." First, Jim hunted Brown's pasture and then, using his swamp buggy to traverse the sometimes-treacherous Kissimmee Billie slough, he moved further south to stake out a "swamp camp" on an island located deep within the Big Cypress Swamp.

Specific ways of being in and moving through the cypress landscape came to define this style of backcountry exploration and hunting in cypress country, including the creation and use of backcountry camps as anchor points for woods expeditions, and the development of swamp-specific forms of off-road transportation.

In Hunters and Bureaucrats, Paul Nadasdy (2004) observes that for the aboriginal Kluane people hunting is not simply the killing of animals (even though it is commonly

\footnotetext{
${ }^{5}$ At the request of the powerful Florida Cattlemen's Association, the State paid men to kill deer in the Big Cypress and Fakahatchee swamps because the deer were believed to be carriers of a disease-carrying tick deadly to cattle (Tebeau 1977, 23). As Cal Stone recounts $(1979,127)$, the State hired hunters at $\$ 80$ per month plus supplies to kill a certain quota of deer.
} 
understood as such by many Euro-North Americans). Instead, Nadasdy outlines how hunting must be understood as part of a broader and more sophisticated set of practices and social relations central to the Kluane way of life. It is important to think more broadly about the hunting practices of white outdoorsmen in the cypress too. While these outdoorsmen are not indigenous people, for them hunting was and is not limited to the acts of finding and killing animals but is part of a broader constellation of practices, technologies, social relations and values that define "being in the woods," including using the woods as an escape from hectic work lives and increasingly crowded coastal cities. Thus, when I talk about hunting in this chapter, I am speaking of hunting as a complex, rich and multi-dimensional activity (how it was often described by the outdoorsmen who I interviewed). I detail the practices, social relations and values associated with "being in the woods" below.

Outdoorsmen first came to the cypress on foot, on horse or via oxcart, and then aboard early swamp buggies made of Model A car parts. One outdoorsmen named Oliver described these early buggies to me:

The early buggies, of course, were largely built on an awful lot of Model A running gear, and they put dual wheels in the back, and you know, they wouldn't have front wheel drive, but they put dual airplane tires in the back, and some, some sort of airplane tires in the front. And, you know, the old solid bar axles that they used to have on the, on the Model A's. And, a lot of times they would, they would add a second transmission in line, so as to be able to reduce the gearing. You know, so that you could put it into super low gear. 
Outdoorsmen claimed land throughout cypress country by physically occupying particular pine hammocks, constructing camps on them and then returning to the same spot year after year. Because hunting was relatively unrestricted and the area largely unfenced, outdoorsmen could locate any desirable pine island or hammock - one with sufficient high ground and abundant game - and setup a temporary camp, as long as it was not yet claimed by others. Outdoorsmen described to me a kind of usufruct, Glades style - that is, if someone repeatedly used a piece of ground and improved it by constructing some type of structure there, then it was his. These land claims, though informal, were enforced by local norms. These local norms (or self-rule as it was described in interviews) included burning out newcomers from an area you had already claimed by constructing a camp, even if your claim wasn't legal.

As one outdoorsmen, Mark - who first started visiting the Glades at age six with his father, an Everglades land surveyor - explained: he and his father wanted to buy land in cypress country, south of the Loop Road. However, people from another rural town had already constructed a camp on the hammock they planned to acquire. Mark and his father decided not to buy the land, because they feared retribution from its current inhabitants even though the Florida City men did not legally own the land. As Mark told me:

"Well, there were some mean people - there's still some mean people around in certain areas, and if they didn't like you or they felt that you had wronged them somehow, they would damage or burn your truck or burn your boat and - you know, burn your camp....It's gotten better but it was a fairly common occurrence back then" (Interview Sept. 21, 2011). 
Backcountry hunting camps served as staging areas for hunting, anchoring excursions into adjacent patches of pine forest and prairie. In addition, camps allowed men to spend multiple nights out in the swamp in pursuit of game, and provided respite from the stresses of daily life. They were spaces for male camaraderie and mischief away from the rigors of work, day-to-day family responsibilities, formal social interactions and the increasingly populated Florida coasts. They also served as places to clean and dress game. A hunter could harvest a deer, turkey or wild pig within the vicinity of a camp and quickly get it back to camp for processing - a necessity for preventing meat spoilage when hunting in south Florida's hot sub-tropical climate.

Many camps began as temporary, makeshift structures assembled in the same desirable spot year after year. In the early days at camp, people slept on palmetto fronds stacked on the ground. Then, they embraced the practice of stringing a tarp between two pine trees and throwing a piece of canvas over it to create a makeshift shelter and cook house. After WWII, many men would use U.S. Army jungle hammocks as shelters at their camp (Interview, September 15, 2011; Interview, September 21, 2011). These hammocks afforded protection from rain and pesky insects. Later, as swamp buggies became more prevalent and building materials more plentiful, people constructed more durable camp "lean-to" structures out of cypress poles, tarpaper and tin. Outdoorsmen then progressed to more sophisticated "stick-built" constructions made from lumber on cement block foundations. In one interview, Oliver - an outdoorsmen who helped to build a cypress camp alongside his father in 1963 - gave a detailed description of their main camp building. 
Rebecca: And, what kind of structure did you build?

Oliver: A conventional stick built construction. You know, two-by-six wall and roof members, covered with plywood, up on about five foot tall concrete block piles that are poured full of concrete, you know, some three foot by three foot bases, eight feet apart, and you know, just set eight foot pieces of six-by-six on top of that, and then you started building the structure, you know, just like you would a stick built house in town.

While the camp described above had one central structure, other camps consisted of a collection of outbuildings including a cook shed, a sleeping porch, a swamp buggy shed and an outhouse.

Sometimes, outdoorsmen would move between several backcountry camps, or establish multiple swamp camps in different parts of the cypress over time. As Cal Stone (1979) details in his book 40 Years in the Everglades, he spent his first ten years exploring the prairies, hammocks and salt marshes south of Loop Road, where he setup his first camp. As more people came into the area south of Loop Road in the 1940s, he moved west to hunt the Fakahatchee Swamp with one of his close friends. There he and his buddy staked out "Turnback Camp" on a dry pine island, but, eventually, in the early 1950s he decided to relocate his camp to the Big Cypress Swamp north of Tamiami Trail near a place called Wildcat Hammock. Stone moved his camp once more in search of greater isolation. He purchased a 40-acre tract of land 16 miles north of Monroe Station in Big Cypress Swamp where he setup his last camp - a permanent backcountry camp called Camp Calusa (Stone 1979, 196). The Big Cypress country became a landscape dotted with hundreds of swamp camps (some rough-hewn, some city-like, most built 
without proper land title) and other rural dwellings. Oliver painted the following picture of the cypress in the 1960s:

There were hundreds of campsites out there at that time. People would take old buses, school buses, old abandoned portable school buildings, you know, they'd knock them down and take them out there and set 'em back up. You know, little plywood and tar paper shacks, and mobile homes, travel trailers...You know, people would take whatever they could out there, and set it up, and that's where they would stay. (Interview, Dec. 7, 2011)

Typically men founded and frequented backcountry camps with friends or family, so their spatial range in the cypress country depended on who they knew or who they had entered into informal lease or access agreements with as well as how deep their sense of adventure ran.

In the 1930s and 1940s, technology, swamp know-how and physical endurance kept most outdoorsmen from travelling into the most remote corners of the cypress, far from the roadways that brought people to the swamp. As Cal Stone (1979) recounts, in the 1940s, most outdoorsmen setup camps within five miles of adjacent roadways like the Tamiami Trail; the thick mud, high water and uneven rocky ground, especially during the spring and summer rainy seasons, limited their travel. Stone $(1979,147)$ explains,

Most people trying to hunt in the 'Glades would go about four or five miles from the nearest road, about the limit of their endurance. Few had swamp rigs able to get them much farther than that. The water was high and the mud was deep most of the spring and summer prior to hunting season. It took some know-how and determination to walk much farther than five miles into the swamp much less to get back. 
However, swamp hunting began to change in the 1950s as the number of hunters coming to the swamp from adjacent towns and cities increased due to a combination of technology, more access roads into cypress country and Florida’s post-war population boom (Stone 1979, Interview January 21, 2011; Interview, December 5, 2011). More sophisticated swamp buggies made backcountry access easier. Swamp buggies enabled hunters to go further into the woods, and to enter "areas where only the hardiest woodsman had previously been able to go" (Stone 1979, 149). By the late 1940s swamp buggies were ubiquitous - the result of army jeeps entering into the public marketplace in the wake of WWII, and cheaper and more abundant parts, tires and tools ${ }^{6}$.

Swamp buggies are folk innovations customized for use in the upland Everglades. ${ }^{7}$ Ultimately, swamp buggies are the epitome of handiwork, ingenuity and swamp savvy. As a motley collection of parts extracted from different machines, and of auto chassis reassembled, swamp buggies were (and are) fashioned according to their owner's liking and skill. No two swamp buggies are exactly alike, and their owners are constantly tweaking their design. Initially, hunters and outdoorsmen built swamp buggies using the steel frames of old cars and airplane tires. One outdoorsmen, Oliver, described

\footnotetext{
${ }^{6}$ Hunters describe many early buggies as being made from $3 / 4$ ton jeeps, which were originally manufactured by Daimler for use by the U.S. Army in WWII (Interview Jan. 21, 2012; Interview Sept. 15, 2011, Interview, Dec. 7, 2011).

${ }^{7}$ In wetter areas of the cypress south of the Tamiami Trail - what locals call "airboat country" - airboats were used to glide across the shallow water (Interview June 24, 2011, Stone 1979). Airboats first came into use in the 1920s (Tebeau 1968). Modern airboats are made out of cypress or steel frames and are powered forward by a two-blade propeller encased in a metal cage, which looks like a giant fan and is connected to an airplane motor (Tebeau 1968). They can draw or move across water only two to three inches deep. The airboats used in the southern Everglades are distinct glades innovations designed to navigate the shallow waters of Everglades marshes and prairies.
} 
his first swamp buggy as an army jeep outfitted with surplus airplane tires and chains for travel across the mucky, rocky and difficult terrain of the Big Cypress Swamp.

It was a 1942 Ford build [4 wheel-drive] model, the World War II military jeep. A couple of factories made 'em. Kaiser-Ford. And, you know, little, short, 80-inch wheel base vehicle with slick twelvefifty by sixteen airplane tires on it. It had tire chains you could put on if you wanted to. And, I guess you're too young to remember the Roy Rogers TV Show series, but there was a character named Pat Brady, who had a jeep of that vintage. And, the name of the jeep was "Nellybelle," and every time Pat Brady drove the jeep, it would break. Well, that was true. Every time we went out in the woods, something broke. ${ }^{8}$ (Interview, Dec. 7, 2011)

Typically, swamp buggy owners would outfit their vehicle with very low gearing

- by installing multiple transmissions - so that it could be put into super-low gear to increase its traction. As Oliver explained,

Rebecca: And, why would you need super low gear? Just to navigate the rough terrain?

Oliver: Well, it makes it, it makes it much better for going over the bumps. And, also, for, for traction purposes, the, you know, any sinking, which all buggies have, into mud or running over, running into water and puddles, provides rolling resistance, and the slower you have the wheels going, the easier it was for the wheels to maintain, the rear wheels to maintain traction... (Interview, Dec. 7, 2011)

\footnotetext{
8 Oliver is likely describing a 1942 Ford GPW 4 wheel-drive military jeep. Between 1941 and 1945, Willys Overland (MB) and Ford (GPW) produced 700,000 of these lightweight 4 wheel-drive jeeps for use by the United States army during WWII (Bunn 2012). After the war, the U.S. Army sold these jeeps to car dealerships, who then sold them to the American public.
} 
Swamp buggies and airboats became tools integral to swamp exploration, swamp hunting and, because they could carry more supplies, backcountry camp construction. These were forms of transportation that evolved with 'glades hunting and exploration. While swamp buggies made travel across the cypress easier and more efficient, the early wave of swamp buggies was highly unreliable and required tough operators with resilience, self-sufficiency and swamp know-how.

...let's face it, when you go out in the swamp, you have to be able to repair things if they break. You're not gonna call a garage or AAA, you have to be pretty selfsufficient, and there is a lot of pride in building [your swamp buggy]. No two are alike. Over the years people have figured out what works best, you know, in buggies, what's most desirable, and years ago people would just throw some contraption together out of old used parts and junk and they weren't very reliable. So there was a lot more breaking down and getting stuck in the old days than occurs now, of course. (Interview, Dec. 5, 2011)

In many interviews, outdoorsmen spent long periods telling detailed sagas about getting their buggies stuck in the mud or having their buggies breakdown after catching the running gear on a protruding rock or cypress knee. Even though swamp buggies were designed to take a beating, they would often break down in the middle of the swamp. Such break-downs required repairs in hot and miserable conditions not for the faint of heart, or long walks through air thick with pesky insects in search of a part or tool. Sometimes outdoorsmen were stranded, working to repair their broken buggies for more than a half-day. Other times, they would have to walk out to their trucks or cars along the 
Tamiami Trail to retrieve parts or weld a broken buggy piece, and then return to the cypress a day later. One man told me how his wife had spent more than a handful of nights out in the palmettos, hunkered down on top of their buggy, as he trudged through the darkness to Monroe Station or to their car in order to retrieve a necessary buggy part (Interview, Sept. 15, 2011).

Outdoorsmen's landscape practices generated particular social geographies. Through the time of Preserve creation, going to the woods was a ritual and a way of life for many of these men. Many outdoorsmen from the southeast coast told me how they would get off work in Miami on Friday nights, drive out to Monroe Station, retrieve their swamp buggies from Monroe Station's parking lot or from the nearby Everglades Conservation and Sportsmen's Club, gas up at Monroe Station and head out into the woods (to their camp, if they had one) for the weekend, their swamp buggies cutting through the night air. As one outdoorsmen, Ben, recounted,

You get off work Friday night, everybody'd be loading up in their swamp buggies and going to work on camp in the middle of the night, and there'd be three or four buggies headed in[to the woods] in the middle of the night. You might get to camp, you might get stuck, you might break, you might not get in. [Chuckle] But everybody had Friday night. We'd come out Sunday and all tried to, you know, come out about the same time in case somebody had a problem. (Interview, Sept. 15, 2011)

Such buggy caravans were common. Outdoorsman understood the value of reciprocity. They were willing to help each other out of sticky situations and buggy break-downs because they knew that someday they too would break an axle or get 
hopelessly bogged down in the mud. They also understood the value of travelling through the woods together in the event that someone broke down. Ultimately, though, cypress hunting and exploration was a way of life that required grit, mechanical savvy, a willingness to learn from trial and error and a thirst for swamp know-how. While other outdoorsmen would lend a hand, each man had to do most of the work required to build and maintain his camp and swamp buggy. As the following interview excerpt underlines, outdoorsmen had to possess enough swamp know-how and self-reliance to hold their own in the cypress.

Rebecca: So how did you know how to build your camp? Are you good at construction? It seems like you have to be pretty handy to take this stuff on.

Ben: Well, you gotta figure out how to build it. There ain't nobody gonna do it for ya.

Rebecca: So you really have to know how to do it yourself.

Ben: That and repair your own swamp buggies and all that.

(Interview, Sept. 15, 2011)

Certain places and institutions anchored this way of life, including jumping-off points like Monroe Station, a way station along the Tamiami Trail with a gas station, restaurant, general store and swamp buggy storage lot (Interview, Dec. 5, 2011; Interview Dec. 7, 2011). Loop Road was also important because of the extensive access it afforded into the cypress, as were private ranches south of Immokalee (Interview, Jan. 21, 2012; Interview March 22, 2012). Moreover, sportsmen's clubs like the Everglades Conservation and Sportsmen's Club located just south of Loop Road's east entrance 
served as gathering venues for like-minded outdoorsmen and sought to promote a principled, conservation-minded approach to swamp hunting (Stone 1979).

Distinct social geographies formed around camps in close proximity. One distinct cluster of camps - which still exist today - developed together on the section of land owned by Cal Stone called the Calusa Ranch (discussed above), which he sold to fellow outdoorsmen he liked. This pattern of regionalization was typical. While going to the woods was an inherently social activity and many hunters socialized at jumping off points like Monroe Station (a gas station, restaurant and general store back then), outdoorsmen were generally most familiar with those people who had camps located closest to theirs in one specific region of the cypress. These social geographies had names, including "south of the Trail," "north of the Trail," "up Turner River" or "inside the Loop." The wife of one outdoorsmen described the social life in these communities of camps in the following way, "[It was] kind of like a woods-based Cheers." (Interview, Dec. 7, 2011)

\section{Entering a New Era of Land Relations and Real Estate Speculation}

Starting in the 1960s, the Big Cypress region and the political economy of its land base began to noticeably change. As Cal Stone has observed, a combination of greater use, more poaching and growing real estate speculation in the 1960s made the Everglades feel less rugged. Most significantly, real estate speculation and land development pressures increased, threatening the informal property relations on which the hunter's landscape was premised. 
By the late 1950s, cypress country's days as an extractive resource frontier were coming to an end. In 1956, two of the area's largest sawmills, Lee Tidewater Cypress Company (1944-1956, 360 million board feet of cypress milled in Perry, FL) and C.J. Jones (1940-1956, pine milled in Jerome), closed their doors, marking the end of south Florida's virgin timber economy (Tebeau 1977). This depleted resource base coupled with coastal development, Florida's post-WWII population growth and improved transportation networks (such as the completion of Florida's second cross-Everglades highway, Alligator Alley, in 1969) fueled inland real estate speculation. On Florida's west coast, Naples grew rapidly from a sleepy coastal town into a vibrant vacation and residential enclave, while Miami boomed on Florida's east coast. ${ }^{9}$ Under such changing conditions, it became more profitable for large landowners in the cypress, like the Colliers, to subdivide their landholdings and sell off smaller parcels for farms, ranches and real estate development. Attitudes toward land shifted as well. Land was seen less as a commons and more as a commodity as people began to assert stronger ownership claims, have land boundaries formally surveyed and land tracts platted, and enforce access restrictions. Property changed hands from the Colliers to other owners often in far-flung corners of the United States - seduced by the promise of sunshine, drainage and development (see Tebeau 1977). While absentee ownership still abounded, property relations were changing in ways that threatened to erode the traditional ways outdoorsmen used and moved through the cypress country.

\footnotetext{
${ }^{9}$ Florida's population grew by $46 \%$ in the 1940s (Gannon 2003, 109). GIs returning home from WWII flocked, with their families, to settle in sunny Florida where they had been stationed for military training exercises. Veterans Administration financing for new homes and advances in mosquito-control technology, air-conditioning and electrical refrigeration made Florida an even more attractive destination (Gannon 2003, 106-108). As Charles Tebeau (1977, 189-190) describes, Naples saw $\$ 1.5 \mathrm{~m}$ in building permits in 1950 , a figure which sharply escalated to $\$ 5 \mathrm{~m}$ in 1955 .
} 
Roadways in and around cypress country - new and old - became corridors for development and real estate sales. Development was most pronounced right off of Alligator Alley - originally a two-lane toll way completed in 1969; the Tamiami Trail; and the gravel roads that sliced into the swamp's interior including Turner River Road, Birdon Road and Loop Road.

Josh, a second-generation camp owner, chronicled the transition in land attitudes as he told a story about how his family acquired their camp in the cypress country.

My dad took us [out hunting in the 'Glades]. We went over and used to hunt - over by Immokalee; and for years, we hunted over there. And the farmers would let you go through there, and then they started locking the gates. So my dad said, "Well, we need to find some land of our own," so then we started looking up where the Big Cypress is now. We looked south [from] the Trail. We looked south and then we went north, then we found the property up there on the Calusa Ranch, where they were willing to sell some of the land. So that's where we bought 40 acres up there in 1962, and started building [our camp] in '63. (Interview, Sept. $15,2011)$

Land speculation prompted some outdoorsmen to pursue proper title to the land on which their camp stood. They worried they would be pushed out or fenced out by the legal owners, if they didn't purchase the land outright themselves. As Josh described:

The Collier family sold that land all over the world. They split it up in little pieces and sold it all over the world... When they put Alligator Alley through, there were people that would go in and buy land (like how they bought Baxter Island). Right where Dad went through before the Alley going north and south. That's at milepost 71 right now. So some guy came in there and bought a section of that land. He 
bought a section of land and he just built a grade one-mile deep into the Big Cypress as we know it south of the alley. Then he just sold a piece here, a piece here and a piece here. Dad got to be worried that they would be fenced out if they didn't own the land. They said, let's see if we can't find where this is, Uncle Ed being a surveyor. They started up Turner River Grade with two buggies and surveying tools in 1960 or 1961 and they surveyed across Airplane Prairie to the east until they got to their particular camp area. And they found that [their] five acres was sold to a lady in Chattanooga, TN. She was the present owner. (Interview, Jan. 21, 2012)

Other outdoorsmen bought land in the cypress during this time because it was readily available and actively marketed. Oliver's father bought their camp at the urging of Dixie Webb, who ran Monroe Station and whose brother owned a Miami-based real estate company involved in swampland sales. The majority of the people I interviewed who own backcountry camps in the Big Cypress National Preserve today, bought their land and constructed permanent "swamp camps" in cypress country during the 1960s.

\section{The Everglades Jetport Controversy}

In the late 1960 s, the development pressures on cypress country came to a head, culminating with a proposal to construct an international jetport in the cypress (Davis 2011). The jetport controversy marked a pivotal moment in the history of the Big Cypress region; it was a defining moment for what kind of place the cypress would become and what its politics of place would look like.

People of all kinds who cared about Big Cypress began to hear rumors in the late 1960s about Dade County's plans to buy land in Collier County and build a massive 
international airport in the cypress (Davis 2011; Interview, March 22, 2012). The then Chairman of the South Florida Flood Control District phoned influential people who had a stake in protecting Big Cypress including environmentalist Joe Browder, hunter and lobbyist Johnny Jones, and special assistant to the Florida Governor, Nathaniel Reed to warn them about the project and discuss its water management implications for the Everglades (Interview, March 22, 2012).

Ultimately, Miami-Dade County officials, developers, and real estate speculators supported plans to turn the Big Cypress Swamp into an international airport, known as the Everglades jetport (Davis 2011). Jetport proponents viewed the jetport as a boon to regional development, and an opportunity to rebrand Miami. The swamp was again seen as intrinsically worthless. The airport idea, clearly the product of high modern hubris, would accommodate supersonic jets on six one-mile long runways (Grunwald 2007, Davis 2011). Proponents argued it would squarely situate Miami on the map as a cosmopolitan and innovative regional center instead of a backwater (Davis 2011). Environmentalists were worried by the proposal and the irreversible ecological damage it would inflict on an already degraded Everglades (Davis 2011). Moreover, environmentalists from a handful of environmental organizations recognized the biological value of the Big Cypress - as one Everglades expert stated "the Big Cypress is the most biologically diverse part of the terrestrial Everglades, which was why it was initially included in the boundaries of Everglades National Park" and had to be protected (Blythe 2012).

Hunters were concerned too. The jetport project threatened the future of Big Cypress as a hunter's landscape. They understood, as Joe Browder put it, that the "Jetport 
was going to be the beginning of the end for the Big Cypress." Hunters recognized that the behemoth Jetport project had the potential to dramatically reduce the landscape's hunting and camping opportunities, and to forever alter its ecology, and their way of life (Interview March 22, 2012).

A coordinated opposition to the jetport was built through an unlikely alliance that included pro-environment public figures, long-time hunters and outdoorsmen, alligator poachers and environmentalists ${ }^{10}$. Joe Browder, an environmentalist working for Audubon of Florida, spearheaded a campaign to stop the Jetport and to protect the Big Cypress from development (Interview, March 22, 2012). The anti-Jetport campaign created the opening for a new kind of collaborative environmental governance in the Everglades because it brought together diverse interests. As one outdoorsmen recalled, "If it wasn't for rednecks and alligator hunters, the Preserve wouldn't exist."

Browder reached out to long-time hunters and outdoorsmen who intimately knew and loved the Big Cypress Swamp - including the famous alligator hunter "Gator Bill" Schoelerman - to enlist their help as partners in the anti-Jetport campaign (Russell 2007). Hunting organizations were well aware of the threat to the Big Cypress posed by the Jetport, and rallied their members to oppose the project. Organizations like the Florida Wildlife Federation, headed by Johnny Jones (a beloved hunter and plumber from Miami), the Broward County Airboat, Halftrack and Conservation Club, the Everglades Conservation and Sportsmen's Club, and the Airboat Association of Florida played an important role in stopping the Jetport. The leaders of these organizations mobilized local

\footnotetext{
10 Not everyone in the outdoorsmen community opposed developing the Jetport. Some outdoorsmen favored airport development because they knew it would enhance the value of their real-estate holdings in the cypress. One pro-Jetport coalition made up of local real estate interests, local people and hunters formed (Interview Dec. 7, 2011).
} 
hunters in opposition to the Jetport and tapped into the influence of pro-hunting interests in the Florida legislature (Interview, March 22, 2012). Browder developed relationships with hunting community leaders like Johnny Jones and worked beside them to devise a coordinated oppositional strategy. As Joe Browder put it:

"...we became real partners [in] strategizing how to stop the Jetport and how to save the Big Cypress....Johnny and I, very quickly, started working together to figure out how this could be stopped. And, Johnny's principal role was to encourage, to organize the whole Florida hunting community including the South Florida hunters to get behind that effort. And, so I spent a lot of time with Johnny in addition to time with organizations like the Airboat Association of South Florida, the Half Track Association of South Florida, and other leaders of the hunting groups using Big Cypress...we all amplified each other's strengths by working together. " (Interview, March 22, 2012)

Hunting community leaders mobilized local hunters against the jetport, and vouched for the environmentalists as credible partners. As Browder emphasizes, "I worked very hard at working with the hunters on what our...strategies would be. What we thought about the biggest individual problems were and how to explain them to everyone, and how to recruit other people to defend Big Cypress..." In an epic act of coalition building, these interests aggressively lobbied the federal government and leveraged public support to save the Big Cypress from what they perceived to be an ugly and illogical fate (Russell 2007, Davis 2011). The jetport proposal went all the way up the federal government's chain of command to President Nixon, who stopped the project (Davis 2011). 
Ultimately, the Jetport controversy was an important historical moment because it brought together and empowered a coalition of interests who would then advocate for the protection of cypress country; it laid the groundwork for the creation of a National Preserve, and staved off the forces of development that would have altered the cypress as a hunter's landscape (in a different way than the National Preserve did). The campaign was premised on an emergent and collaborative form of environmental governance that recognized the emplacement of local outdoorsmen in the cypress country and empowered them to participate in the environmental politics of progress. Those involved in the jetport controversy acknowledged that cypress county was a hunter's landscape and the importance of hunters to protecting it. The Jetport was a unique moment in Everglades history because it recognized the emplacement of local people in the Everglades landscape, and acknowledged their place attachments and practices as central to Everglades protection. It empowered local people to play influential roles in Everglades protection, and for a short time, advanced the idea that local people were integral to protecting the Everglades in the long-term. The jetport opened up the conditions of possibility for a new, more equitable kind of environmental governance to take hold in the Everglades.

\section{Discussion}

\section{The Big Cypress Region - An Embodied Place for Outdoorsmen}

As I've illustrated in the account above, outdoorsmen know the Everglades in a physical and tactile way - from moving through it on foot and by machine. For them, the Everglades has a raw physicality and a stubborn resiliency - it is a place of burning sun, 
sticky mud, protruding cypress knees waiting to snag a swamp buggy axle, sloshing water and wet feet, epic swamp buggy breakdowns, swamp buggy movement and stoppage, building swamp camps from scratch out in the elements and feeling like you are a visitor in a place that can never quite be tamed. Outdoorsmen know the Big Cypress through sensory experiences and life experiences shaped by their unique practices of traveling to and from camp, building swamp camps, moving through cypress strands and pine islands while hunting, searching for delicate orchids in the midst of familiar cypress domes, and visiting other camps to socialize with their dwellers - it is a place of lived experience for them and an extension of their rural lives elsewhere. Outdoorsmen don't understand Big Cypress country synoptically (from above) or virtually. For outdoorsmen the Everglades, especially Big Cypress country, is an embodied place.

As Edward Casey (1996) writes, there are two essential traits of place: 1) that the lived body in motion is a key component of emplacement, or being in place, and 2) that "places gather." As Casey observes, "the body is the specific medium for experiencing a place-world" (1996, 24). Casey describes how the multiple articulated physical structure and the sensory capabilities of the human body allow people to enter and experience places through movement, and sensory perception. He writes, "Precisely by allowing us to make a diverse entry into a given place - through hands and feet, knees and hips, elbows and shoulders - the body insinuates itself subtly and multiply into encompassing regions" (21). In this way, our "living-moving" bodies integrate with place, and places integrate with bodies by responding to the way we sense, move through and transform them - bodies and places come together to create a "flesh of the world" (23) or sense of place. 
Casey further describes three specific types of bodily motion central to place: 1) staying in place, 2) moving within a place and 3) moving between places, which help us to understand how Big Cypress country is a lived place for outdoorsmen. Outdoorsmen's unique sense of place in the Big Cypress country emerges through what Casey terms, "the crucial interaction between body, place and motion" $(1996,23)$. Outdoorsmen stay in one single place - their tree stands or hunting spots - during hunting season. There they sit as still as possible for hours. Yet, during this time, they continue to make small motions with their limbs, and their chest rises and falls with their breath. They perceive the woods through their five senses - observing movement, feeling the breeze across their skin, and smelling heavy air. Outdoorsmen stay in a single place when they have to repair their buggies in the middle of the swamp, if they have the right tools. Outdoorsmen move within their backcountry camps actively building camp structures from the ground-up and then moving through various camp spaces as part of the camp rituals of cooking, sleeping, drawing water, showering, sitting by the fire, observing wildlife, goofing around, routine maintenance, and hunting game in the nearby woods ${ }^{11}$. Outdoorsmen also move within certain staging areas, like Monroe Station - places where they pack their buggies with camping gear, cooking supplies, swamp buggy parts and, sometimes, camp construction materials for their trip into the woods, often while trading stories and swapping tips with other outdoorsmen heading out into the woods.

Outdoorsmen move between (to and from) a number of places in the Big Cypress country - travelling and transitioning from their rural and suburban homes to trail access points in and around the Preserve and then journeying to their backcountry camps (and

\footnotetext{
${ }^{11}$ Typically, backcountry camps are conceived of by their owners/users as not just built structures but also as encompassing adjacent areas of woods where camp-goers hunt and explore.
} 
vice versa). They also move from an access point like Monroe Station through the Preserve on a network of branching trails, which take them to their camp. Outdoorsmen traverse the terrain between their camp and other nearby camps for friendly visits or swamp buggy repair. Moving between their camp and a favorite hunting spot, outdoorsmen trek through cypress domes and pine forests.

A second dimension of place, Casey asserts is that "places gather" - they hold together people, memories, histories, experiences, material objects and landscape features in complex configurations. It is through a particular complex configuration that the Big Cypress known to outdoorsmen (their sense of place) emerges - creating a sense of order, of relationships between how things are "even when those things are radically different and quite conflictual" (1996, 25). Casey continues, "The arrangement allows for certain things - people, ideas, so forth - to overlap with and sometimes to occlude others as they recede or come forward together" (25). Thus, "Being in place is being in a configurative complex of things" (25). Defeat of the jetport project maintained the configurative complex of things that was the hunter's landscape in the Big Cypress, and opened the door to collaborative negotiations over its protection.

\section{Nostalgia, Myth-Making and the History of the Big Cypress Region}

The creation and celebration of heritage - a selective remembering and ordering of the past by individuals or groups - often results from "traumas of loss and change and fears of a menacing future" (Ray 2001, Lowenthal 1996). As anthropologist Celeste Ray (2001) notes, heritage is an engagement with the past - often a past mythologized - for present purposes. As she writes, "Heritage is history told from a certain viewpoint and 
told purposely 'for"' $(2001,16)$. As I discuss in greater detail in Chapter 6, the contemporary Gladesmen identity and heritage has emerged from outdoorsmen's larger frustrations about being marginalized in the space of natural heritage created, branded and perpetuated in the contemporary Everglades by federal land management agencies like the National Park Service and the U.S. Army Corps of Engineers. Outdoorsmen who self-identify as Gladesmen recount how they have lost territory and influence in this new Everglades - they explain that they are no longer able to use and access Everglades lands that they once hunted, fished and travelled across, and that little room remains for their stories and concerns in a representational space seemingly dominated by the National Park Service and environmental NGOs. These landscape politics have prompted some outdoorsmen's search for roots, identity and belonging, and sharpened their sense of nostalgia - cornerstones of heritage formation (per Lowenthal 1996, 4-10).

The Merriam-Webster dictionary defines nostalgia as "a wistful or excessively sentimental yearning for return to or of some past period or irrecoverable condition.” In social theory, while nostalgia is characterized as an act of remembering or longing for the past, scholars also attend to its political, mythological and spatial dimensions.

Nostalgia is political and powerful in that it can cast people and landscapes in a mythologized and almost mystical light. For example, as Bruce Braun notes, John Muir imagined wilderness and the nation as spaces of natural and racial purity in ways that, in reality, never existed but have a potent cultural productivity $(2003,203)$.

Following Edward Casey, Gaston Gordillo examines how "nostalgia implies a particularly intense spatialization of memory" $(2004,248)$, which includes the "integration of disparate localities in a single historical geography" $(2004,253)$ in the 
Argentinean Chaco. Gordillo shows us how nostalgia can involve creating memories of past places that may not be real, yet those people remembering them hope they will materialize in the present. Gordillo continues, "Remembering and its sedimentation in space are constitutive of experiences of labor and locality; they guide practices, struggles and hopes and connect the places in which memories are produced with vanished and contemporary landscapes" $(2004,253)$. Gordillo also underlines how nostalgia functions as a form of social memory with social implications - a kind of collective recall designed to reposition a particular social group and give them a more favorable (less marginalized) place in the world.

As this chapter shows, outdoorsmen who self-identify as Gladesmen and support the idea of a Gladesmen culture are clearly mythologizing the past and remembering it for very political, social and spatial reasons. When Gladesmen and outdoorsmen recount the history of the southern Everglades, they typically invoke "a complex of injustice" beginning with creation of Everglades National Park and what the national park took from local people. In the minds of Gladesmen, the designation of Everglades National Park in 1947 first fomented local grievances over use and access while the Big Cypress National Preserve became the next big battleground. Self-described gladesmen will name off other lands where they have been pushed out and where motorized use has been severely limited, including the Loxahatchee National Wildlife Refuge.

While there are disparate histories surrounding these public lands and different government agencies involved, Gladesmen have melded these public lands into one narrative about the Everglades geography and what the federal government does in it: the federal government pushes out local users, curtails motorized use and locks users out of 
its protected areas, even if it says it won't. Yet, the historical narrative that Gladesmen tell obfuscates the property relations that enabled the hunter's landscape to emerge in the Big Cypress region, and the subsequent development pressures that began to rapidly transform cypress country independent of the federal government and the National Park Service (as detailed in this chapter).

\section{Conclusion}

In summary, chapter 3 illuminated the unique place history that defines outdoorsmen's life histories and place attachments, and contextualized Gladesmen's nostalgia for a landscape lost (to the National Park Service). The Big Cypress was a distinct hunter's landscape from the 1930s on, characterized by unique property relations, practices and social relations. Through these practices hunters forged important understandings and attachments to this unique landscape - it became a source of meaning and value for them, and shaped a distinct place-based identity and sense of place. Yet, under development pressures, this landscape began to change and a collaborative campaign among hunters and environmentalists for protecting the Big Cypress was mounted. However, as I detail in Chapter 4, the way outdoorsmen understand the Big Cypress as a place is different from the way the NPS and environmentalists see it, and is different from the kind of place it has become as a national preserve. In Chapter 6, I trace how outdoorsmen's historic practices, which I have detailed in this chapter, have evolved into a kind of white identity politics for a subset of self-identified Gladesmen, and into contemporary claims to a place-based Gladesmen heritage. 


\section{REFERENCES}

Blythe, Robert

2012 Interview with Joe Browder at Cosmos Club, Washington DC. Feb. 7 transcript. EVER-1892. South Florida Collections Management Center, Everglades National Park, Homestead, FL.

Braun, Bruce

2003 On the Raggedy Edge of Risk: Articulations of Race and Nature After Biology. In Race, Nature and the Politics of Difference, Donald Moore, Jake Kosek and Anand Pandian, eds., Pp. 175-203. Durham, NC: Duke University Press.

Bucuvalas, Tina, Peggy A. Bulger, and Stetson Kennedy

1994 South Florida Folklife. Folklife in the South. Jackson, MS: University Press of Mississippi.

\section{Bunn, Don}

2012 Segment Fourteen: 1940 to 1980 Power Wagon Pickups. http://www.pickuptrucks.com/html/history/segment14.html. Accessed Jan. 11, 2012.

Casey, Edward

1996 How to Get from Space to Place in a Fairly Short Stretch of Time:

Phenomenological Prolegomena. In Senses of Place. Stephen Feld and Keith Basso eds., Pp. 13-52. Santa Fe: School of American Research Press.

Davis, Jack E.

2011 An Everglades Providence: Marjory Stoneman Douglas and the American Environmental Century. Athens, GA: University of Georgia Press.

Grunwald, Michael

2006 The Swamp: The Everglades, Florida and the Politics of Paradise. New York: Simon and Schuster.

Duever, Michael J., John E. Carlson, John F. Meeder, Linda C. Duever, Lance H. Gunderson, Lawrence A. Riopelle, Taylor R. Alexander, Ronald L. Myers and Daniel P. Spangler.

1986 The Big Cypress National Preserve. $2^{\text {nd }}$ printing. Research Report No. 8. New York: National Audubon Society.

Gannon, Michael

2003 Florida: A Short History. Revised edition. Gainesville, FL: University Press of Florida. 
Gordillo, Gaston

2004 Landscapes of Devils: Tensions of Place and Memory in the Argentinean Chaco.

Durham, NC: Duke University Press.

Lowenthal, David

1996 Possessed by the Past: The Heritage Crusade and the Spoils of History. New

York: The Free Press.

Nadasdy, Paul

2004 Hunters and Bureaucrats: Power, Knowledge and Aboriginal-State Relations in the Southwest Yukon. Vancouver: UBC Press.

Ogden, Laura

2011 Swamplife: People, Gators and Mangroves Entangled in the Everglades.

Minneapolis: University of Minnesota Press.

Ray, Celeste

2001 Highland Heritage: Scottish Americans in the American South. Chapel Hill, NC: The University of North Carolina Press.

Russell, Nancy

2007 Interview with Joe Browder in Everglades City. Dec. 7 transcript. EVER-1410.

South Florida Collections Management Center, Everglades National Park, Homestead, FL.

Stone, Cal R.

1979 Forty Years in the Everglades. Tabor City, NC: Atlantic Publishing Co.

Simmons, Glen, and Laura Ogden.

1998 Gladesmen: Gator Hunters, Moonshiners and Skiffers. The Florida History and Culture Series. Gainesville, FL: University Press of Florida.

Tebeau, Charlton

1968 Man in the Everglades: 2000 Years of Human History in the Everglades National Park. 2nd edition. Copeland Studies in Florida History, No. 3. Miami, FL: University of Miami Press.

1977[1957] Florida's Last Frontier: The History of Collier County. Paperback edition. Copeland Studies in Florida History, No. 1. Miami, FL: University of Miami Press.

U.S. National Park Service

2000 Final Recreational Off-Road Vehicle Management Plan and Supplemental Environmental Impact Statement. Big Cypress National Preserve, Florida. 


\section{Chapter 4: The Politics of Place and Knowledge in the Big Cypress National Preserve}

\section{Introduction}

In writing about conflicts over the management of the temperate rainforest in British Colombia's Clayoquot Sound, Bruce Braun (2002) reminds us of the inadequacies inherent in framing and studying environmental struggles as simply debates between "stakeholders" with "divergent interests." Braun asserts that just "bringing people into the same room [is] not sufficient for a radical environmental democracy" because of their different epistemologies, visions of nature and unequal power relations $(2002,5)$. Instead, Braun argues, these struggles necessitate a "sustained examination and appreciation of the multiple ways" in which a forest, or a swamp, is "invested with meaning and value," and "an examination of our passionate attachments" to such places $(2002,5)$. Braun stresses that these are passionate attachments "whose histories are not merely personal, but political (shaped by power), not merely local, but carried from afar" (Braun 2002, 5). In this way, Braun draws our attention to the way nature "is a deeply cultural and political space" $(2002,8)$ at the center of local-global articulations, and how "the one nature" that emerges from such consensus negotiations is an effect of power.

In this chapter, I assert that through National Preserve creation, the Big Cypress region became a bureaucratic place rather than the hunter's landscape known to outdoorsmen, and that this transition unsettled the emplacement and environmental trusteeship of outdoorsmen in the Everglades. As the cypress country began to transition into a public conservation landscape - a unit of the National Park Service - it was subsumed by new logics of natural resource management, and seen through the optics of 
documentary knowledge and imperiled global nature. The Big Cypress region was no longer comprehensible or important solely within the confines of lived bodily experience and the local context of outdoorsmen. It was now linked to ways of seeing nature associated with environmental conservation projects, state improvement programs and larger debates about the proper stewardship of public national parkland. These ways of understanding and knowing nature by "seeing like a state," and "seeing like an ENGO" gave rise to a new place formation where environmental organizations became more central actors, and ushered in new monocular visions and understandings of nature, which created tensions between outdoorsmen and environmental organizations. These tensions can be best understood through an analysis of the ongoing politics of place and knowledge surrounding the management of nature in the Big Cypress National Preserve (BICY), debates which traffic more in ideology than science.

\section{Theoretical Orientation}

Anthropologists have offered important critiques of environment and development projects, which prove central to my examination of the different visions of nature that have come to shape the Big Cypress National Preserve as a place. In his important book Seeing Like a State (1999), James Scott illustrates how state institutions

exercise power and influence through a narrowing of vision that simplifies and standardizes peoples and landscapes to make them legible for state improvement purposes, such as revenue generation or maximizing production. Through this process of "rendering legible," citizens are reduced to statistics and landscapes are reduced to 
cadastral maps. In this way, states "strive to shape a people and a landscape that will fit their techniques of observation" (Scott 1999, 82).

Drawing on ethnographic fieldwork in the central Sardinian town of Orgosolo, Tracey Heatherington's (2010) book Wild Sardinia addresses a trio of intertwined themes: ecology, alterity and resistance while also providing an insightful critique of environmentalist engagements with local cultures and landscapes. The central metaphor woven throughout Heatherington's book is "the global dreamtimes of environmentalism," which is at once a critical commentary on and a way of framing environmentalist practices and worldviews. Heatherington draws upon Aboriginal Australian conceptions of the "Dreamtime," to point to the potent cultural productivity associated with the way environmentalists "see" and represent ecologically valuable landscapes. Heatherington elaborates: "I argue that we can understand the dreamtimes of environmentalism as a supple dimension of cultural imagination which overlays regional geographies with stories evoking the presence of a universal, sacred, transcendent, timeless and global Nature - a Nature now increasingly at risk, apparently demanding new forms of reverence" $(2010,23)$. In particular, Heatherington describes how big environmental NGOs (BIngos) like the WWF and TNC have risen to increasing prominence and power since the 1990s, and are in the business of translating local cultures and landscapes into global universals easily recognizable to cosmopolitan elites. Heatherington underlines how the practice of local-to-global translation is a defining element of "the global dreamtimes of environmentalism." She writes: "Global approaches to ecology and environment constitute a strategic field of imagination within which social and political 
relations of power are negotiated and naturalized...spaces in which the signs of locality are remapped and transmuted into potent universals" $(2010,21)$.

In this chapter, I build upon these literatures to examine how the process of "rendering legible" (Scott 1999) has reshaped the way the people and landscape of the Big Cypress National Preserve are understood and managed by outside conservation trustees (NPS, ENGOs) while displacing outdoorsmen from the landscape. I pay particular attention to the role ENGOs have played in re-imagining and repositioning the Big Cypress region as an ecologically valuable form of global nature. Specifically, I attend to the ways more global ENGO imaginaries and ENGO litigation have prompted the National Park Service to more swiftly "see like a state" and render the Big Cypress landscape into more bureaucratic and legally legible forms of nature by re-ordering it into discrete management objects like ORVs and the endangered Florida panther.

\section{The Creation of the Big Cypress National Preserve: A Shifting Politics of Place}

As I detailed in Chapter 3, the campaign to oppose the Dade County jetport in cypress country created the conditions for a collaborative form of environmental governance that recognized the emplacement of local outdoorsmen in the cypress country and capitalized on their unique place attachments and political connections, empowering them to participate in shaping south Florida's environmental future.

Yet the battle for cypress country was far from over after hunters, environmentalists and their allies defeated the jetport proposal. Even after the Nixon Administration quashed the Big Cypress Jetport project, real estate speculation in the cypress continued. This prompted a handful of outdoorsmen and environmentalists, 
building on their newly created coalition, to start discussions about how to protect the landscape from growing development pressures.

And so when the jetport was stopped, then the next question, well, this is not gonna go away, I mean this is only the beginning. You know, we're seeing more and more real estate signs, people are selling property lots down off of Loop Road, maybe we need to look at protecting the Big Cypress... And there again, there was lots of discussion amongst the local culture and the local community about whether this was a good idea and how to go about it, and most people I knew were somewhat supportive. 'Cause if it was paved over and developed you weren't gonna hunt there, you weren't gonna camp, you weren't gonna have what you had before. (Interview Sept. 21, 2011)

Discussions between government officials, outdoorsmen and environmentalists ensued about the right conservation strategy for protecting the Big Cypress region perpetuity. Many local hunters advocated for land protection under the Florida Fish and Wildlife Conservation Commission. However, the State of Florida lacked the necessary funding, so leaders in the land protection effort floated proposals to the federal government.

The National Park Service reluctantly stepped in to protect these lands, but only after Congressional action forced them to consider this new category of NPS park unit. As Joe Browder explained to me, many in the National Park Service and the Department of Interior vociferously opposed the idea of the Big Cypress National Preserve. They were uncomfortable with the precedent that would be set by allowing hunting and motorized vehicle use in a National Park Service unit, and argued it was incompatible 
with the NPS mission ${ }^{1}$ (Browder interview, March 22, 2012; see also Sellars 2009 for a broader historical overview). Some NPS officials and environmentalists wanted the Big Cypress to be annexed into Everglades National Park ${ }^{2}$ so that it could be managed like a traditional park (Browder interview, March 22, 2012). Yet, central figures in the negotiating process, like Joe Browder, recognized that such a plan for national park expansion was inequitable, and would not accommodate the hunters who had worked so hard to save the Big Cypress, and for whom this landscape held tremendous importance. As Browder told me, “...this historic national park approach of having to sweep the area clean of any evidence of humanity wasn't necessary to achieve the ecological goals, wasn't equitable to people who were giving everything they knew how to save the place" (Browder interview, March 22, 2012). Thus, the idea for a national preserve, which would allow a greater number of uses, gained traction.

Many outdoorsmen and local people supported the idea of a national preserve because they believed that it would protect their way of life and their practices. Yet, like all state projects, the Big Cypress National Preserve would come to be viewed and understood through certain bureaucratic logics and optics not necessarily commensurate with local perspectives. As Scott observes, in order for state institutions to be able to intervene in local landscapes they need to be able to read and reduce "a large and complex reality... to schematic categories" (Scott 1999:77) - this requires reassembling the landscape into a forms they can apprehend by creating bureaucratic legibility.

\footnotetext{
${ }^{1}$ Moreover, the National Park Service had just come off of an intense internal debate about the role hunting should play in national park units vis a vis the control of species populations (see Sellars 2009), creating strong internal opposition to hunting.

2 The original boundaries proposed for Everglades National Park included the land area that would become the Big Cypress National Preserve in 1974 (Browder interview, March 22, 2012).
} 


\section{Ways of Knowing the Preserve}

With national preserve creation, a new complex configuration (Casey 1996) of landscape actors and objects came to the foreground in the Big Cypress region. National preserve creation kicked off a reconfiguration of the assemblage of objects (human and non-human) understood to constitute the Big Cypress National Preserve as a place, in accordance with the social, institutional, legal and political logics of NPS-led environmental conservation. As a newly minted federal landscape, it created an opening for new actors to speak for, represent and attach their logics to nature. The cypress country started to become a new kind of place: a public conservation landscape defined by new ways of seeing and apprehending nature, and by new actors who were concerned about its stewardship. A synoptic view from above and certain documentary practices, such as map-making, became important to discussions about the ecological health and protection of the Preserve and to recasting the Big Cypress region as a definable landscape of discrete objects that could be managed apart from its socio-historical context. I invoke several vignettes to illustrate this change in vision.

\section{National Preserve Place-Making}

BICY's authorizing legislation began the process of "rendering legible" the Big Cypress landscape for bureaucratic intervention. "Seeing like a state," Congress recast the Big Cypress region as a collection of discrete objects and practices amenable to natural resource management (rules and regulations deemed necessary by the Secretary of the Interior). First, even though hunting and motorized vehicle use were historically 
interconnected and part of a larger constellation of socio-historical practices known as "going to the woods," the Big Cypress National Preserve's enabling legislation separated them from one another, and situated these activities within the realm of recreational activities $^{3}$.

The transition to a state-controlled landscape on the ground was a difficult one. As the first national preserve in the United States, BICY proved an enigma for the National Park Service. The National Park Service was used to cultivating uninhabited scenic landscapes for tourist consumption, guided by the virtualizing vision of parklands as untouched wilderness. BICY was the epitome of a peopled landscape with over 500 backcountry camps and 500 permanent residences dotting a cypress swamp the size of Rhode Island, and a well-established community of hunters using the landscape at the time of national preserve creation (NPS 2000).

As far as I can tell, the NPS was initially baffled by the landscape they inherited, and resorted to viewing it as a set of real estate transactions required to create the bureaucratic totality whose boundaries were demarcated by Congress. The NPS approached and understood BICY through the optic of formal property rights - as land parcels within the discrete boundaries drawn on a map by Congress that needed to be acquired to create the pristine and primitive "wilderness" discussed in the legislative history. The NPS went about purchasing as many inholdings, or private lands, as possible from willing sellers within Preserve boundaries. Early BICY leadership also focused on addressing the over 1,000 structures present on the lands designated for national preserve creation, and on sorting out who did and did not own the land on which these camps and

\footnotetext{
${ }^{3}$ A framing and vision that would later contribute to debates about ORVs in the Preserve.
} 
houses stood. To the NPS, the only people who remotely belonged in the landscape were those who held proper land title to their land. The NPS concentrated on phasing out what they termed "squatter" camps and on reordering the landscape based on legal property claims. However, this proved to be a messy and drawn out process, lasting well into 1986 (Duever 1986) and was met with vocal opposition by those with "squatter" camps. Like all parks, the Big Cypress National Preserve was overlain on a landscape with a rich and deep human history - but one not so easily erased. At the end of the day, approximately 100 privately owned camps (each on 3 acres) remained within BICY's boundaries (NPS 2000).

\section{The Documentary Realities of NPS Nature}

When a piece of land becomes a unit of the National Park Service, the NPS must manage it within a particular political and legal context. This context is laid out by the legislation, executive orders and NPS policies that govern the operations of the entire National Park system including the Organic Act (1916) as amended by the Redwoods Act (1978), the Wilderness Act (1964), the National Parks Omnibus Act (1998) and the National Park Service Management Policies (amended in 2006) as well as by legislation specific to each park unit, including its enabling legislation. In addition, because they are federal actions, the environmental impacts of management decisions made by each NPS park unit must be analyzed, and are subject to public scrutiny, under the National Environmental Policy Act (NEPA). In this way, NPS nature has a legislated, policy-based and legal reality - or a documentary reality - as well as a material reality. Yet, the material realization of the documentary nature of the Big Cypress National Preserve - as 
envisioned by pertinent Congressional legislation, NPS policies, executive orders and legal precedents - remained incomplete on the ground. As Paul Schullery writes in reference to Yellowstone National Park, "We say that Yellowstone National Park was established on March 1, 1872, but in fact we have never stopped establishing Yellowstone...we...continue to create it...it is...a crucible of ideas, ambitions, dreams, and belief systems; a cultural, intellectual and spiritual crossroads at which we are forever debating which way to turn" (2004, 1-2). While the historical trajectory and iconography of Yellowstone National Park is vastly different than that of the Big Cypress National Preserve, it is fruitful to think about BICY too as an unfinished project between people and nature that continues to unfold from the documents that created it as they are sharpened into focus.

In the House and Senate reports that accompanied the Preserve's enabling legislation, members of Congress addressed the management of motorized vehicles within BICY. The Senate Report's lead author, Senator Jackson, wrote:

Since the area to be included in the Preserve is largely undeveloped at the present time and because it will be managed in a manner which will assure its return to the true wilderness character which once prevailed, it will offer many outdoor recreation opportunities to the visiting public.... While the use of all-terrain vehicles must be carefully regulated by the Secretary [of the Interior] to protect the natural wildlife and wilderness values of the Preserve, the bill does not prohibit their use along designated roads and trails. (U.S. Congress 1974, 4-5)

In BICY's 1991 General Management Plan (GMP), NPS managers at the Big Cypress National Preserve textually aligned themselves Congress' wishes regarding motorized vehicle management in the Preserve. In the 1991 GMP, the NPS indicated that 
it would develop a comprehensive ORV management plan. However, as far as I can discern, the NPS did not actively develop a formal or comprehensive strategy for managing all-terrain or off-road vehicles until they were pressed to do so by a 1995 lawsuit filed by the Florida Biodiversity Project, an environmental NGO. This lawsuit forced the NPS to follow-through on the ideas it articulated in the 1991 GMP, and required the NPS to regulate the practices of ORV users and ot develop an ORV management plan. Specifically the FBP lawsuit used the Big Cypress National Preserve's policy, legislative and legal mandates, as outlined by Congress, to compel the National Park Service to bring BICY under more intensive management and oversight.

The Act of August 25, 1916, known colloquially as the National Park Service Organic Act, lays out the mission of the National Park Service. This Act, which created the National Park Service, states: "The service thus established shall promote and regulate the use of the Federal areas known as national parks, monuments, and reservations... which purpose is to conserve the scenery and the natural and historic objects and the wildlife therein and to provide for the enjoyment of the same in such manner and by such means as will leave them unimpaired for the enjoyment of future generations." In the context of BICY (and other National Park units), this legislation, the Redwoods Act and the NPS Management Policies are cited in lawsuits and policy letters as proof that the NPS "has a statutory conservation mission [to prevent the impairment of its resources] and [its] goals and objectives must be consistent with that mission" (FBP 1999 quoted in NPS 2000, 204). The FBP argued this point in its 1995 lawsuit.

Leveraging two key pieces of federal legislation - the Clean Water Act and the Endangered Species Act - as well as existing legal and policy mandates surrounding NPS 
actions, the FBP plaintiffs argued that the NPS was failing to adequately protect Preserve resources as demanded by current laws and policies, and failing to adhere to the precautionary principle in relation to ORVs. ${ }^{4}$ The precautionary principle can be defined as follows: in cases of uncertainty as to the impacts of activities on park natural resources, prudent and conservative actions should be taken to ensure that protection of park natural resources will predominate (NPS 2006). Specifically, it alleged that the BICY GMP was in violation of ESA and CWA and cited a handful of cursory wildlife studies to argue that ORV use was harming the endangered Florida Panther in uplands habitats. The lawsuit also alleged that the NPS was privileging visitor use and access over resource conservation (an age-old debate over NPS lands). Ultimately, environmentalists argued that NPS was not adhering to its non-impairment mandate, and they prevailed in court.

The lawsuit and the political and legal documentary reality it introduced became central to figuring out how to manage "ORVs in NPS nature", in the context of a national reserve, and to the design of a Big Cypress National Preserve Off-Road Vehicle

\footnotetext{
${ }^{4}$ For a thought-provoking critique of the precautionary principle as a guise for managing nature on strictly biocentric terms see Alston Chase 1997. As of 1979, there were "over 50 regularly used access points where ORVs would leave main roads and travel into the backcountry" (Duever 1986, 313). At the time of Duever's report, people were using swamp buggies, airboats, track vehicles, all-terrain cycles and trail bikes (dry season) in the BCNP. "By counting vehicles stored in the area and by interviewing hunters and game wardens, we estimated that approximately 800-1000 swamp buggies, 100-200 airboats and 50-100 track vehicles are active in BCNP at the peak of the hunting season... and 100-200 ATCs are used in the preserve, but they are rapidly growing in popularity" (Duever 1986, 306). "Although there are no data on the numbers of ORVs in South Florida before 1969, ORV impacts (which are presumably related to ORV numbers and intensity of use), are visible in early aerial photography....In 1940 there were 93 miles of visible trails. In 1953 there were 155 miles and by 1973 over 682 miles. These were not all the trails in existence at these times, but only those trails impacted enough to be visible in high altitude aerial photography....The 1940 and 1953 trails resulted primarily from logging activities... and the greatly expanded trail system of 1973 is the result of increased recreational ORV use, which is primarily associated with hunting....The highest densities of trails are found south of Loop Road and within a five-mile radius of Monroe Station." (Duever 1986, 300).
} 
Management Plan in $2000^{5}$. It also precipitated debates that continue to dominate

management discussions today about: What qualifies as impairment? When is such harm deemed to be 'serious' or 'irreversible?' In what ways, if at all, are ORVs impairing the ecological integrity of the Big Cypress National Preserve?

The 1995 lawsuit forced the NPS to "see like a state" and figure out how to frame and justify the rational management of "ORVs in NPS nature" as part of the preparation of the required ORV management plan. The ORV management plan was supposed to be science-based. However, the NPS had conducted few management studies up to that time (save for a baseline resource assessment, see Duever 1986). Thus, the NPS turned to several synoptic technologies as the appropriate management tools for measuring resource impairment and designing proper stewardship strategies.

Using maps, and aerial photography the NPS recast the Big Cypress region as a definable landscape of ORV trails that could be managed and understood through technoscience. The NPS commissioned several studies to establish the basic facts about ORV impacts, and to support the comprehensive management plan they were developing. The NPS contracted with the University of Georgia to prepare a GIS-based assessment of the National Preserve's trail system and vegetative impacts. The University of Georgia prepared a map depicting a bird's eye view of all the linear features in the National Preserve. The NPS included this map in the 2000 ORV plan to illustrate its discussion

\footnotetext{
${ }^{5}$ While I have not fully addressed this issue here, the political economy of off-road vehicles was changing in ways had a significant impact on the politics surrounding their use on public lands. Since the 1980s, offroad vehicles had become increasingly more affordable, more popular and more widely available to the general public through corporate manufacturers like Polaris. These same corporations heavily marketed recreational off-road vehicles as symbolic of the unfettered freedom people should have to use public lands, and as in sync with rural values, the push for decreased state regulation, and national pride (see Wuerthner 2007). This broader socio-political context began to inform public debates about public lands stewardship, and to alarm many pro-wilderness advocates. This issue merits additional consideration in my work.
} 
about the intensity and deleterious effects of ORV use over time. The NPS also used images taken in January 2000 from fixed wing aircraft and helicopters. These images depicted places in the trail system with striking proliferations of crisscrossing tracks and mud ruts. A suite of such images from above appear in the 2000 ORV management plan, posited as evidence of adverse impacts to the BICY landscape.

\section{ORVs Don't Belong}

Environmental groups seized upon the University of Georgia map and other visually dramatic photos of ruts and serpentine dirt trails bisecting BICY to make their case against ORVs. Environmentalists took UGA's estimate that the trail system encompassed 29,000 and used it to make the argument that these machines were undeniably degrading BICY's resources. In fact, they claimed that BICY's ORV trails were so extensive they could wrap twice around the globe (Sierra Club). Yet, how well these visual claims approximated actual damage to the Preserve's water flows, soils, wildlife and plant communities was uncertain and remains largely understudied.

Outdoorsmen and others have questioned these optics of degradation. In fact, Michael Duever, one of the preparers of the first Big Cypress resource inventory commissioned by the NPS (Duever et al. 1986) and the lead investigator on two ORV impact studies (Duever 1981, 1986), stated in a court deposition for the 1995 lawsuit: "Based on my observations and studies of ORV activity in BCNP, it is my expert opinion that operation of ORVs in BCNP, while creating discernable effects on the Preserve, are not creating biologically or ecologically significant impacts on the overall BCNP ecosystem" (NPS 2000, 381). In its 1999 comment letter on the draft ORV management 
plan, the Florida Fish and Wildlife Conservation Commission - when discussing the NPS' analysis of ORV impacts on BICY soils - also asserted: "The pertinent question that needs to be addressed...is whether this type of [ORV] use constitutes an adverse effect on the Preserve's resources or merely creates a temporary visual impact" (NPS 2000, 374). Yet these images and maps have taken on an influential and powerful moral life of their own and became the subject of an ongoing debate about the extent to which ORVs are impairing BICY's resources.

In fact, the Big Cypress National Preserve has risen to prominence as a battleground for limiting motorized recreation on public lands, and was drawn into the national debate about motorized use on public lands. Around the time of the FBP lawsuit in 1995, the Big Cypress National Preserve became the poster child for pro-wilderness, anti-ORV campaigns run by local and far-away environmental groups including Wildlands Center for Preventing Roads (Missoula, Montana) ${ }^{6}$, Bluewater Network, a division of the international Earth Island Institute (Berkeley, CA), and the National Parks Conservation Association (Washington DC).

Environmental organizations dominate this debate portraying all the ORV users of Big Cypress National Preserve as one group: thrill-seeking and reckless leisure consumers who have no concern for the local environments they are destroying (see Bluewater Network 2001, Davenport and Switalski 2006). All forms of motorized access in Big Cypress - swamp buggies, track vehicles, all-terrain vehicles, airboats and trail bikes - were posited as universally deplorable and damaging. As one advocate with Friends of the Earth, Erich Pica, quipped in a New York Times (Canedy 2002) article: 
"What you have is a minority of the population using Big Cypress and other places around the nation as an amusement park for their thrill vehicles."

As a result, a space of representation has taken shape, premised on the legislated vision for BICY as a nationally significant conservation landscape, and successive campaigns by environmental organizations, which foregrounds concerns about the negative impact of ORVs on the wilderness experience, the Florida panther and water flows in the Big Cypress National Preserve, both inside and outside the courtroom. One of the main ways environmental organizations have made their case outside the courtroom is by introducing this frame of reference into media coverage in regional and national newspapers including the New York Times and LA Times, complete with visually compelling photos of ORV trail rutting in the Preserve (Photos 2 and 3).

As W.T. Mitchell has argued, landscape re-presentation is a powerful cultural medium with potent cultural productivity. Landscape representations frame ways of seeing and being in nature (mediated by certain cultural values) but also actively produce them. In this case, environmental NGOs have constructed the Big Cypress as a landscape where motorized access is universally damaging and reckless and does not belong, and they have attempted to render that vision as the norm. These landscape representations have in mind (and wish to produce) larger environmentalist publics both close-by and far away who are concerned about environmental degradation, especially of wilderness landscapes, and who may be potential donors to and supporters of anti-ORV campaigns. Yet these landscape representations obfuscate the regionally specific cultural practices that underpin swamp buggy and airboat use and, in many ways, differentiate them from stereotypical ORV use in other lands. Moreover, these representations preclude 
meaningful discussions about the historical roots of swamp buggy and other motorized use in the southern Everglades, and the conservationist values that some swamp buggy users may too espouse.

While some outdoorsmen agree that changes in ORV practices were necessary after BICY's creation, they believe environmentalists used "images from above" to make exaggerated claims about effects of ORV use on BICY's resources and to wrest outdoorsmen from their role as partners in determining BICY's management. As one environmental group declared: "Indeed, much more remains to be done in the coming years in order to guarantee that [the] Big Cypress [National Preserve] assumes its rightful place among the nation's natural treasures and to ensure that the Preserve and its resources are enjoyed by generations to come, rather than managed as a private playground for a few.” (Wildlife Advocacy Project)

\section{ORVAC}

Outdoorsmen have since reclaimed a spot at the negotiating table through the creation of an Off-Road Vehicle Advisory Committee (ORVAC) created by the NPS in 2007. However, the politics of place and knowledge have shifted - outdoorsmen now have a more adversarial relationship with environmental NGOs, a deep-seated bitterness towards the National Park Service and a nostalgia for a mythologized past when the cypress country afforded greater freedom of movement and practice.

Every several months, outdoorsmen, environmentalists and other appointed committee members who include two university professors, a realtor and a county commissioner convene to discuss and design BICY's ORV trail system. What was 
peculiar to me as I sat in on these public meetings, was the role that Google Earth maps play in representing BICY's landscape and in structuring the discussion about its trail system. Google Earth turned the complex network of trails crisscrossing BICY into one comprehensible image or a God's eye view of the trails. Google Earth shows BICY's ORV trails glowing like Technicolor arteries on a one-dimensional plane. Observing this translation, I couldn't help but return to the critical remarks of Bruno Latour and Bruce Braun in relation to knowledge production. As Latour (1999) so presciently asks in his study of the documentary practices of science: How do we turn the world into words [or images]? And, as Bruce Braun (2002), inquires about effacements enacted by mapmaking: what gets lost in the process?

It is clear to me that so many of the situated, lived and storied dimensions of the Preserve are lost in the one-dimensional and ahistorical representation of ORV travel on a Google Earth map. Moreover, these dimensions are often buried even further when thinking about outdoorsmen's practices through the optic of a linear "trail system" that can be designed by a group of stakeholders. The use of Google Earth is a way for the NPS to "see like a state" and make the knowledge of many individual outdoorsmen visible and comprehensible to all ORVAC participants and NPS staff, while at the same time reducing this knowledge into a management object ${ }^{7}$. The ORVAC process renders the trail system and backcountry legible to a techno-managerial process focused on limiting total trail miles, ensuring trail locations avoid sensitive habitat and laying out procedures for managing trail use. However, by focusing on GIS layers and maps

\footnotetext{
${ }^{7}$ Most hunters on the ORVAC only know certain parts of the Preserve extremely well and several members of the ORVAC and NPS staff have not spent extensive time in the Preserve and are not intimately familiar with its landscape or the layout and feel of its trails or camps.
} 
displayed on screens, it is also a process that leaves out valuable oral histories, place attachments and that separates "ORVs" out from a constellation of local, place-based practices. Indeed, the world of planning for the Preserve's off-road vehicle trail system is one of meeting room negotiations, synoptic maps and views from above. It is a disembodied Big Picture - a way of seeing the Big Cypress region and BICY from above and a way of containing and holding together this landscape as a set of discrete objects amenable to natural resource management.

\section{Panther Politics}

As one hunter recently told me in a phone conversation, "The panther is no longer a flesh-and-blood animal. It has become a political animal" (Phone Conversation, Jan. 10, 2013). In his excellent book, Ranching, Endangered Species and Urbanization in the Southwest, Nathan Sayre (2002) describes the role endangered species play as a form of symbolic capital in struggles over nature. Sayre points out how endangered species become an integral part of the ideological arguments deployed by environmentalists about how nature should be managed and protected as a pristine, unspoiled space free from human interference. I argue that debates over BICY stewardship, the Florida Panther has functioned as a similar kind of symbolic currency for environmentalists and has enabled them to not only press the National Park Service to further regulate BICY's human use, but to discursively reposition BICY as one of the ecologically valuable and fragile pieces of global nature that needs to be protected from human use.

ENGOs, as a result of their growing memberships and influence in the 1960s (Kline 2007), played an important role in passing the key environmental legislation of the 
1970s focused on pollution control and public lands management. ${ }^{8}$ Environmental groups helped pass significant federal pollution control and environmental protection laws including the Clean Water Act (1972), Coastal Zone Management Act (1972), the Endangered Species Act (1973) and the Safe Drinking Water Act (1974) (Kraft 2001: 8687). These landmark pieces of legislation provided a policy and legal toolkit for environmental groups to leverage while also creating certain spaces of visibility (Gregory 1994) through which to value and manage nature. Environmentalists often work to fit their causes into strategic slots that align with the larger regional and national politics and priorities created by these key environmental laws.

Like in other ecologically valuable landscapes, endangered species $^{9}$ have become an important marker of Everglades imperilment and an important way for Everglades ENGOs to make their case about why the Everglades is worth saving. For example, the Everglades Coalition, an alliance of local, regional, state and national environmental organizations dedicated to the protection of the Everglades, wrote in its 1993 blueprint for saving the Everglades: "A long list of endangered species signals the degraded health of the natural system" (1). Today, almost all Everglades advocacy documents written by environmental NGOs spell out the fact that the Everglades is home to over 68 federally listed species (e.g. Everglades Coalition 2010).

\footnotetext{
${ }^{8}$ The 1960 s gave rise to the modern environmental movement, which centered on environmental quality concerns. Americans rallied against the environmental degradation caused by the industrial growth and industrial pollution associated with rapid post-WWII economic growth (Kraft 2001; Kline 2007). Choking smog, dirty water, DDT and industrial smoke impacted the lives of many everyday Americans, and they sought outlets for expressing their concerns about environmental degradation.

${ }^{9}$ The Endangered Species Act of 1973 defines an "endangered species" as "any species which is in danger of extinction throughout all or a significant portion of its range."
} 
This is no different for the Big Cypress National Preserve where the endangered Florida Panther, the last surviving subspecies of Puma in the eastern United States, has come to the fore as a symbol of ecosystem decline and potential redemption. Numerous ENGOs including Defenders of Wildlife, The Nature Conservancy and the Florida Wildlife Federation work with state agencies and other partners to encourage panther recovery across a mosaic of public and private lands. In fact, the USFWS recently released an updated panther recovery plan (USFWS 2008). The Big Cypress National Preserve is one surviving piece of the Florida panther's historic range. Viable panther habitat once encompassed much of the southeastern United Stated ranging from Arkansas and Louisiana eastward across Mississippi, Alabama, Georgia, Florida, and parts of South Carolina and Tennessee (Young and Goldman 1946); however only 5\% of this historic range remains due to rapid land use change and the encroachment of development (USFWS 2008). Researchers have found that the Everglades region south of the Caloosahatchee, and the Big Cypress Swamp are home to the only surviving breeding populations of Florida panther (approx. 100-120 individuals) (USFWS 2008, 4). Moreover, researchers have concluded that a portion of the northern Big Cypress National Preserve is a Primary Priority Zone for panther habitat conservation (Kautz et al. 2006).

The panther has become iconic in its own right for many environmentalists who use it to draw attention to the management and stewardship of the Big Cypress National Preserve by the National Park Service, especially in the context of contemporary debates over the appropriate extent and intensity of Off-Road Vehicle use in the Preserve.

Environmentalists have sought to reduce the amount and extent of ORV use in the 
Big Cypress National Preserve, litigating on at least four occasions since 1974 to require the National Park Service to impose further regulations on this use. Press releases detailing the two most recent lawsuits over ORV trails and use in the Big Cypress National Preserve use the Florida Panther as a kind of strategic capital to establish why these lawsuits should matter to wider audiences. One press release appeared on CommonDreams.org, detailing the multi-organizational 2011 lawsuit over the number of ORV trails open in the Bear Island unit of the Preserve. Its title and subheading read: "Big Cypress ORV Plan Triggers Lawsuit Threat: Proposed Trail Network Poses Threat to Florida Panther and Other Protected Species." NPCA issued a press release on its separate 2011 lawsuit over the expansion of ORV use into the Additional Lands. NPCA's subheading cued into wildlife enthusiasts' concerns for the charismatic Florida Panther and the federal government's responsibility to protect this animal and its habitat under the Endangered Species Act. The article title and subtitle read: "National Parks Conservation Association Files Suit Against Park Service for Failure to Protect Big Cypress National Preserve in Florida: General Management Plan limits protection of Florida Panther habitat in Addition Lands" (NPCA 2011).

In this way, environmentalists have crafted a representational space where they juxtapose the image of the Florida panther, a charismatic species of megafauna, to less desirable uses such as Off-Road Vehicles in the Preserve that don't fit well within environmentalist's vision for an adequately protected and restored Everglades, which affords ample untouched wilderness experiences.

The Florida Panther has been used as a way of positioning ORV users as others to environmentalists, and thus casting ORV users as inappropriate and backward users of 
this landscape. This portrait paints ORV users with a broad brush, depicting them as despoilers who are located outside the landscape without any real attachments to it or without any real conservation ethic, who come only to drive across it and destroy it as a form of leisure. While there are certainly important questions to ask about the management of ORV access and the intensity of ORV use in BICY and about the specific effects of ORV use on BICY habitats, some ENGOs have invoked hyperbole to make their case against ORVs, arguing online, in litigation and in key news coverage that the motorized hunting enabled by ORVs significantly diminishes the panther's prey base (feral hogs and whitetail deer), and that ORVs harass panthers and drive them out of BICY during the annual hunting season - claims that lack a substantive scientific basis. In fact, one of the region's Panther biologists, David Maehr, who studied the panther for eight years, stated in a court deposition for the Florida Biodiversity Project v. Kennedy case that: "The landscapes of eastern BCNP [outside of the BCNP Additional Lands and the Bear Island Unit] and Everglades National Park [ENP], while presumed by many to be important panther habitat, are likely unimportant to the future of this endangered species...the result of a predominance of low productivity soils, sparse forest cover, inundated landscapes and low prey densities" (NPS 2000, "Affidavit of Davis S. Maehr," 392-293). Maehr's conclusion was that, "There is absolutely no published evidence that off-road vehicles (ORVs) disturb Florida panthers in the Big Cypress National Preserve or elsewhere that I am aware of" (NPS 2000, 392). Despite scientific uncertainty, the South Florida Wildlands Group has largely framed BICY as the last remaining piece of viable habitat for the Florida Panther - an assertion contested by other environmentalists.

Thus, these discursive reductions are acts of "incongruous translation" 
(Heatherington 2010,156) because they not only oversimplify the local context of ORV use and the landscape history of the Big Cypress National Preserve in order to connect it to more global preservationist discourses about parkland wilderness and endangered species, but they also serve as texts designed to legitimize the authority of ENGOs. These representations position ORV users as reckless and backwards users, and question whether their presence is desired in such a globally valuable ecological system.

In my discussions with hunters during my 2011 field surveys, there were evident tensions about who the Big Cypress National Preserve was being managed for. Many hunters told me with disdain that they believed Preserve managers were stewarding the land more for Florida panthers and tourists. Moreover, many hunters were frustrated with the way the panther, as an endangered species, has been used in environmental litigation and by the USFWS to limit hunting and ORV use in the Preserve. They told me that they did not feel welcomed; instead they felt like an ugly remainder in a landscape celebrated by outside publics for other reasons.

\section{Knowledge Politics}

Both of these processes have drawn the Preserve further into the realm of documentary practices and documentary knowledge - a realm where official reports, multi-layered technical images, lawsuits and political-legal objects like endangered species matter more than on-the-ground personal observations. The Big Cypress National Preserve of today is a world of bureaucratic legibility.

The context in which knowledge about nature is created and circulated matters. As Paul Nadasdy (2003) reminds us, knowledge encompasses "what people know, what 
they wish to know and what they feel is appropriate and possible to know..." and is embedded within a broader social context. Knowledge is also shaped by power relations that dictate what can count as knowledge and who its proper bearers are. Thus, environmental knowledge is undeniably a form of capital and claims-making that is produced, applied and circulated in the management of nature, and is always evolving (Goldman and Turner 2011). As a result, it is important to understand how different environmental knowledges and understandings of nature come into being and circulate in environmental struggles. In the case BICY, it is clear that there was little room for outdoorsmen's voice and perspective in the ways the cypress country was apprehended and constructed through the logics of natural resource management and through the optics of the political and legal documentary reality that structures NPS nature.

It is obvious that outdoorsmen, ENGOs and the NPS are not always discussing and contemplating the same Everglades. The cypress country known to those in the policy and management worlds is different from the cypress country sensed, understood and lived by outdoorsmen. The Big Cypress National Preserve predominantly becomes legible through maps, meeting spaces, legal briefs, courtrooms and policy documents - a less embodied, and more visual, symbolic and textual form of nature. BICY is considered iconic for what it means to Americans and the world.

The ability to engage in the policy world of BICY management requires a different skill set, including the ability to read complex bureaucratic reports and engage with policy processes. Typically, this means that a person has an advanced degree and understands how environmental litigation works so he/she can provide knowledge and feedback that are bureaucratically legible. Moreover, BICY management is largely 
governed by a different kind of ethos, including environmentalist zeal, a will to improve a fragile Everglades, the willingness to engage in seemingly endless negotiations with people you don't really know and the will to produce and analyze large documents. Some outdoorsmen are learning how to code-switch and travel between these two worlds but initially the Everglades policy world was a fraught and foreign country to them. For them, the Everglades is a wild, resilient and tough landscape that has taught them life lessons (not a fragile wilderness) and a social milieu where people keep their word and strike lasting deals with handshakes. In many ways, outdoorsmen have struggled with the Big Cypress region's transformation into a kind of documentary reality and documentary nature.

\section{Conclusion}

In this chapter, I have shown how the Big Cypress National Preserve has become a different kind of place under NPS stewardship. BICY is now defined by a documentary reality and bureaucratic legibility; it is no longer the lived landscape outdoorsmen are intimately familiar with. In debates about the stewardship of cypress country today, it is clear that outdoorsmen, ENGOs and the NPS are not always debating the same Everglades. Instead, they are looking toward different desired assemblages of humans, animals, plants and swamp machines. Moreover, I have shown how "seeing like a state" and "seeing like an ENGO" oversimplify many of BICY's sociohistorical complexities, while at the same time creating discursive representations that displace outdoorsmen from the landscape epistemologically and morally. The trajectory of place-making under the National Park Service, with pressure from environmental NGOs, has limited the kinds 
of claims outdoorsmen can now make to BICY. Up until recently, outdoorsmen weren't able to produce the technoscientifc maps and bureaucratic studies that have come to define BICY's management (studies often motivated by court orders). Their anecdotal accounts of the landscape and their place attachments don't always have a way of entering these debates as knowledge that matters. Instead of becoming partners in BICY's management through collaboration or co-management, and having their role in the making of this landscape recognized (as dwellers integral to its formation), they have been relegated to background in this new world of bureaucratic legibility.

Today, outdoorsmen direct much of the bitterness about their disappearing way of life in the Everglades towards the NPS. Outdoorsmen view the NPS as the cause of these losses, relying on a historical distortion that downplays the ways real estate speculation and regional development have transformed the Big Cypress region since the 1960s. Yet, as I explore in Chapter 6, some of these outdoorsmen are learning to act as code switchers and insert themselves and their histories back into BICY's contemporary document-based reality. 


\section{REFERENCES}

Braun, Bruce

2002 The intemperate rainforest : nature, culture, and power on Canada's west coast. Minneapolis: University of Minnesota Press.

Blue Water Network

2001 Environmentalists Intervene in Big Cypress Thrill-Craft Lawsuit. Press Release. March 20. http://www.commondreams.org/news2001/0320-12.htm (Accessed May $11,2011)$

Canedy, Dana

2002 Advocates and Drivers Reach Fork in the Off-Road. New York Times, March 24.

Chase, Alston

1997 Some Cautionary Remarks About the Precautionary Principle. Countdown to Kyoto Conference, Canberra, Australia. August 1997.

Davenport, John and T. Adam Switalski

2006 Environmental Impacts of Transport, Related to Tourism and Leisure Activities. In The Ecology of Transportation: Managing Mobility for the Environment, John Davenport and Julia Davenport eds., Pp. 333-360. The Netherlands: Springer.

Duever, Michael, John E Carlson and Lawrence A Riopelle

1981 Off-Road Vehicles and Their Impacts in the Big Cypress National Preserve. Report No. T-614. Homestead, FL: National Park Service.

1986 Long term recovery of experimental off-road vehicle impacts and abandoned old trails in the Big Cypress National Preserve. Report No. SFRC-86/09. Homestead, FL: National Park Service.

Duever, Michael J., John E. Carlson, John F. Meeder, Linda C. Duever, Lance H.

Gunderson, Lawrence A. Riopelle, Taylor R. Alexander, Ronald L. Myers and Daniel P. Spangler.

1986 The Big Cypress National Preserve. $2^{\text {nd }}$ printing. Research Report No. 8. New York: National Audubon Society.

Everglades Coalition

1993 Everglades in the $21^{\text {st }}$ Century: The Water Management Future. Second Printing. 2010 Everglades Coalition 2020 Vision for the Everglades. Jan. 7. Everglades

Coalition Conference. Palm Beach Gardens, FL. January 2010. 
Goldman, Mara J. and Matthew D. Turner

2011 Introduction. In Knowing Nature: Conversations at the Intersection of Political Ecology and Science Studies, Mara J. Goldman, Paul Nadasdy and Matthew D. Turner, eds. Chicago: University of Chicago Press.

Heatherington, Tracey

2010 Wild Sardinia: Indigeneity and the Global Dreamtimes of Environmentalism. Seattle, WA: University of Washington.

Kautz, R., R. Kawula, T. Hoctor, J. Comiskey, D. Jansen, D. Jennings, J. Kasbohm, F. Mazzotti, R. McBride, L. Richardson, and K. Root

2006 How much is enough? Landscape-scale conservation for the Florida panther.

Biological Conservation 130:118-133.

Kraft, Michael E.

2001 Environmental Policy and Politics. New York: Longman.

Kline, Benjamin

2007 First Along the River : a Brief History of the U.S. Environmental Movement. Lanham, MD: Rowman \& Littlefield.

Latour, Bruno

1999 Pandora's Hope: Essays on the Reality of Science Studies. Cambridge, MA:

Harvard University Press.

Nadasdy, Paul

2004 Hunters and Bureaucrats: Power, Knowledge and Aboriginal-State Relations in the Southwest Yukon. Vancouver: UBC Press.

Mitchell, W.T.

1994 Landscape and Power. Chicago: University of Chicago Press.

National Parks Conservation Association (NPCA)

2011 National Parks Conservation Association Files Suit Against Park Service for Failure to Protect Big Cypress National Preserve in Florida. NPCA Press Release. October 12.

http://www.npca.org/media_center/press_releases/2011/big_cypress_suit_101211.ht $\mathrm{ml}$ (Accessed October 24, 2011)

New York Times

2002 Nature Overrun. Editorial. April 4. 
U.S. National Park Service 2000 Final Recreational Off-Road Vehicle Management Plan and Supplemental Environmental Impact Statement. Big Cypress National Preserve, Florida.

Sayre, Nathan F.

2005 Ranching, Endangered Species and Urbanization in the Southwest: Species of Capital. Tucson, AZ: University of Arizona Press.

Scott, James C.

1998 Seeing Like a State: How Certain Schemes to Improve the Human Condition Have Failed. Yale Agrarian Studies. New Haven: Yale University Press.

U.S. Fish and Wildlife Service 2008 Florida Panther Recovery Plan (Puma concolor coryi). $3^{\text {rd }}$ Revision. Atlanta, GA: U.S. Fish and Wildlife Service, Southeast Region.

U.S. Congress. Senate.

1974 Establishing the Big Cypress National Preserve, Florida. August 22. $93^{\text {rd }}$ Cong., $2^{\text {nd }}$ Sess. House Report 93-502.

Wuerthner, George

2007 Thrillcraft: The Environmental Consequences of Motorized Recreation. Foundation for Deep Ecology.

Young, S. P. and E. A. Goldman

1946 The Puma - Mysterious American Cat. Washington, DC: American Wildlife Institute. 


\section{Chapter 5: The U.S. Army Corps of Engineers and the Sociopolitical Complexities of Everglades Restoration}

\section{Introduction}

From the standpoint of biophysical science, ecosystem restoration is defined as, "the process of assisting the recovery of an ecosystem that has been degraded, damaged, or destroyed" usually as a result of human activity (SER 2004). Restoration typically involves focused human intervention aimed at returning an ecosystem in decline to a prior model state. This model or ideal state is based on a reference ecosystem or reference landscape that is determined through the analysis of historical data. As the SER Primer on Ecosystem Restoration (2004) notes, "restoration attempts to return an ecosystem to its historic trajectory." Ecosystem restoration is regarded as an important building block in worldwide efforts to conserve biodiversity and foster sustainable development (SER 2004)

Estimated to cost $\$ 19.7$ billion (GAO 2007: highlights) and spanning an 18,000square-mile area over 16 counties in south Florida, Everglades restoration represents one of the most ambitious, complex and comprehensive ecosystem restoration efforts in the world (SFERTF 2002).

Yet, Everglades restoration is also a discourse - a body of ideas and practices that creates a particular space of visibility (Gregory 1994) for nature. In particular, the discourse of Everglades restoration that is heavily promoted by the federal government, the lead agency for restoration, links the Everglades to the conceptual space of the nation, by foregrounding the Everglades ecosystem as “America's Everglades.” For example, all official U.S. Army Corps of Engineers (hereafter "Corps") reports and communications 
about Everglades restoration including its comprehensive website, evergladesplan.org, and its Everglades Report bi-monthly newsletter are branded with the slogan "The Journey to Restore America's Everglades." The state partner in Everglades restoration, the South Florida Water Management District, also has a section on its website dedicated to "America's Everglades." In addition, non-governmental actors use this slogan, indicating its widespread currency. The Everglades Foundation, one of the primary nongovernmental players in Everglades restoration, is organizing a restoration summit in Washington D.C. in May 2010 titled "America's Everglades Summit."

I contend that this conceptualization enables the state to imagine and represent the Everglades in certain ways (but not others). In this paper, I specifically focus on the Tamiami Trail restoration project and illustrate how the Corps spatializes and naturalizes an idealized technocratic vision of the Everglades through the "documentary practices" (Escobar 1995) surrounding this project. Moreover, I contend that the Corps' documentary practices - its representation of so-called facts on paper - reinforce the discourse about Everglades restoration as the stewardship of a national and public resource, by abstracting the Tamiami Trail project from its local context and history. Specifically, I analyze three selected maps and images from the Corps' 2009 Tamiami Trail project factsheet. I argue that these representations portray the Everglades (nature) as an empty, unpeopled landscape amenable to hydrologic engineering. I assert that these images 1) reflect federal claimsmaking to the Everglades as a national and public resource and 2) reinforce the Corps' institutional capabilities for transforming this landscape. 
My discussion is framed by Bruno Latour's (1986) concept of inscription. Inscription refers to the translation of three-dimensional objects and events into twodimensional representations that can be read, compared to and combined with other twodimensional representations (summarized in Braun 2002, 219). Latour (1999) explains that there is not a direct correspondence between reality and words. Instead, he argues that every inscription is made possible by multiple of acts of translation. Each act of translation is a simultaneous act of reduction (simplification) and amplification of a real object facilitated by a network of human and non-human actors.

Drawing on Latour, I assert that the maps and images produced by the Everglades by the U.S. Army Corps of Engineers are inscriptions made possible by acts of translation that amplify certain aspects of the Everglades over others and are mediated by the Corps' network of institutional actors and guiding concepts.

My claims also build on two key literatures: the anthropology of development and the production of nature. Each of these literatures examines the importance of documentary practices - especially maps - in constructing and reinforcing certain representations of reality.

At the end of the day, the Corps representational practices matter because they create a future vision for the Everglades. While not hegemonic, this vision is powerful because it condones certain resource management practices and reinforces certain ways of thinking about the Everglades (as a pure, people-free nature; or as a nature external to humans). Because the U.S. Army Corps of Engineers is the lead agency on this project, its understandings of the Everglades (nature) also "delineate a field of politics" in which certain actors are marginalized and others are authorized to speak for nature in project 
decision-making (Braun 2002, 33). Thus, this state vision of the Everglades is important to attend to because it structures the terrain for project decision-making. In addition, it is important to attend to the blindspots of this (and any) resource management vision. From a social justice perspective, this vision's reliance on a nature/culture binary introduces certain roadblocks to understanding the Everglades as a socio-ecological system (Ogden 2008) and to discussing how humans could responsibly "dwell" in this landscape (Braun 2002, Cronon 1995).

\section{Background}

Lauded as a model for other ecosystem restoration projects across the globe, Everglades restoration aims to undo the damage caused to south Florida's wetlands by the federally authorized Central and Southern Florida project. The CSF project, an ambitious flood control and water management project constructed by the U.S. Army Corps of Engineers in the 1940s, includes 1,000 miles of levees and canals, 15 square miles of interconnected water reservoirs, 150 water control structures, and 16 major pumping stations that are still in service today.

Specifically, the goal of Everglades restoration is to rehabilitate the highly engineered landscape of south Florida in order to "get the water right." (Doyle 2008). Concretely this means, that "the quantity, quality, timing and distribution of the water to the natural system have to mimic as closely as possible [the Everglades'] predrainage conditions" (SFERTF 2000, 15). The feasibility of such a goal is hotly contested given that over $50 \%$ of the historic extent of the Everglades has been lost to development (CISRERP 2008). Other tough questions proliferate as well including: "Restore what? In 
whose interest? What is native, original or natural and who defines this?" (Braun 2002, 252)

Everglades restoration is designed as a federal-state partnership. Project implementation responsibilities are shared by the U.S. Army Corps of Engineers and the South Florida Water Management District. Thus, "the state" has an important role in setting the administrative tone for and policy context for this natural resource management strategy.

Congress authorized the majority of Everglades restoration projects when it passed the Water Resources Development Act (WRDA) 2000. However, certain projects known as the "Foundation projects" predate CERP (CISRERP 2008).

One such Foundation project, the Modified Water Deliveries project, was first authorized by the U.S. Congress in 1989 as part of a bill to improve freshwater deliveries to Everglades National Park. Mod Waters is considered a major building block for the overall restoration plan (GAO 2007), but it is also one of the most protracted and most controversial projects in Everglades restoration (see CISRERP 2008). Ongoing today, the Modified Water Deliveries project was singled out by a National Academy of Science review panel in 2008 as especially troubling and emblematic of the delay and challenging social struggles confronting restoration as a whole.

One component of this multi-part project, the bridging of the Tamiami Trail, is one of the projects most critical to restoring the health of the southern Everglades and jumpstarting system-wide restoration. The Trail runs along the northern boundary of Everglades National Park (the Park), separating it from Water Conservation Area 3 and the remaining southern Everglades. From a biophysical standpoint, because it bisects and 
compartmentalizes the southern Everglades, the Trail impedes adequate freshwater flows from entering the Park with concomitant impacts on nutrient cycling and primary productivity in Shark River Slough. The agencies charged with restoration planning recognize that bridging and other modifications to a 10.7-mile section of the Trail are needed to rehydrate Everglades National Park and revive its natural systems.

Yet, bridging the Tamiami Trail remains one of the most divisive Everglades restoration projects. Heated debates over the cost, configuration and impacts of bridging have delayed and complicated bridge construction and road modifications. Over the past twenty years, the project has been reconfigured over five times (see U.S. Army Corps of Engineers 1992, 2003, 2005, 2008; U.S. Department of the Interior 2010) has faced numerous lawsuits, and has been the focus of hundreds of newspaper articles. Currently, the Corps is working to construct a one-mile bridge across the eastern segment of the project area, while the Park Service has initiated a planning effort to assess the feasibility of additional bridging.

\section{Literature Review}

\section{Translating the World into Words}

My analysis of the three maps and images produced by the Corps draws from Bruno Latour's (1986) concept of inscription. Inscription refers to the translation of three-dimensional objects and events into two-dimensional representations that can be read, compared to and combined with other two-dimensional representations (summarized in Braun 2002, 219). 
In his investigations into scientific practice, Latour (1999) wants to understand "how do we pack the world into words?" through inscription. Through his ethnography of the practice of science in the Boa Vista forest of Brazil, Latour (1999) illustrates that there is not a direct correspondence between reality and words. Instead, he asserts that there is always a gap between representation and reality. Acts of translation made possible by certain intermediaries bridge this gap. In science, each act of translation by a researcher is facilitated by instrumentation such as Euclidean geometry, tables, file cabinets, suitcases. Latour explains that every act of translation is an act of reduction (simplification of a complex reality) and amplification (enhancement of a certain aspect of that reality) facilitated by a chain of different human and non-human actors. But, he underlines, these acts of translation always lead us away from local objects and events in the act of creating inscriptions.

\section{The Anthropology of Development}

In his seminal critique of development, Escobar illustrates how institutions are one of the main forces that produce and structure development projects. Via documentary practices that rely on inscription, including "program descriptions, evaluation reports, research reports, meeting documents, scholarly papers and so on" (Escobar 1995, 112), Escobar outlines how development institutions attempt to reorder and translate the varied and complex social realities of the Third World onto paper. These representations are produced in accordance 1) with the categories of the development discourse and 2) in ways amenable to institutional intervention (Ferguson 1994; Escobar 1995). 
Development reports, for example, simplify the complexities of the local reality and amplify those aspects of that reality, if any, that support a development intervention.

Development is premised on a conceptualization of world geography that divides countries into two categories - the modern West and the amodern "rest", who are in need of technical assistance from the West. Development institutions, like the World Bank, use this schematic to order and describe countries in their development reports. In this way, the development discourse creates recognizable categories and relations, such as the illiterate peasant or the underdeveloped nation, but precludes other ways of seeing (Escobar 1995).

As a result, development is a homogenizing discourse (Ferguson 1994, 70) that causes development institutions to abstract objects from their local context and resituate them within a global and institutional domain of thought and action (Escobar 1995). In this way, development is premised on an erasure of locality. As James Ferguson (1994) shows in his case study of the World Bank's development interventions in Lesotho, development institutions simplify a complex social reality and abstracts from the local context in order to create an object that links up with the universal categories of development. Specifically, Ferguson examines how the World Bank constructs Lesotho in the mold of one the driving "tropes" of development, the Less Developed Country (LDC) (Escobar 1995, 47). Ferguson points out that the World Bank's portrait of Lesotho, while flawed, echoes certain essentialized attributes of underdevelopment, fitting it into one of the client categories created by the development discourse.

Moreover, development institutions portray the issues confronting countries and regions in ways that "require precisely those [technical solutions], which development 
agencies are setup to provide" (Ferguson 1994, 70). Specifically, Ferguson shows how development institutions render social problems apolitical by abstracting them from larger political and cultural processes and casting them as purely technical problems. He illustrates how the World Bank portrays Lesotho as an isolated and depressed national economy (ignoring the larger structural and political causes of its poverty and marginalization) because such a discrete object is amenable to the World Bank's national and sector-based economic programs.

These documentary practices are powerful because they represent and preserve a given social reality over others. Importantly, this reality reflects the extra-local imperatives and schemata of the institution producing the representation. Thus, Escobar emphasizes that documentary practices are not one-to-one representations of social reality but are mediated by the institutions that produce them.

\section{The Production of Nature}

In the context of rational forest management, Bruce Braun $(1997,2002)$ and James Scott (1999) illuminate how maps and representations attempt to spatialize and naturalize certain resource claims, visions of nature, and resource management ideas. Braun and Scott illustrate how such inscriptions are not objective one-to-one representations of nature. As Braun notes, "nature itself does not speak through these images" $(2002,222)$.

Braun discusses how the timber corporation MacMillan Bloedel (MB) represents British Columbia's temperate rainforest in such a way as to legitimize its role as a forest manager. It portrays these forests as a purely natural and apolitical public resource that it 
is sustainably and scientifically managing in its company reports and communications. By constructing the forest as unmarked abstract entity purified of any local social and cultural claims and subject only to the whims of natural history, this strategic textual maneuver makes it possible to tie this landscape to the abstract administrative space of the state. This move displaces First Nations land claims from the forest and naturalizes MB's ability to speak on behalf of the forest.

Braun also discusses how a map produced by the Sierra Club/Wilderness Society - representing a dramatic reduction in the spatial extent of the ancient temperate rainforest over time - was an inscription. Braun explains, "What appears as a single image is in reality the result of thousands of acts of translation done by dozens, if not hundreds, of people (and more than a few machines" $(220) \ldots$ it is the product of countless mundane practices by many different actors: satellites, airplanes, cameras, cartographers, forest biologists, computer technicians, and printers" (221). Braun emphasizes that this map was important because it provided a view from above of B.C. forest resources.

Braun also notes that this map reflected the institutional imperatives of the environmental organizations who produced it. Braun writes, "Here was an image that established, irrevocably, the truth of what activists had been saying for years: the forest on Vancouver Island was vanishing" (Braun 2002, 216). This image gave these environmentalists newfound strength, authority and voice. It enabled them to widely disseminate their message that the forest was disappearing and to build a wide-ranging constituency focused on stemming forest loss. Moreover, this map build on the concepts from equilibrium ecology that influenced the thinking of these organizations - namely 
that nature is external to humans and maintains its own balance. Guided by this key principle, the map functioned as a boundary-making device, amplifying the distinction between unmodified pristine nature (ancient forest) and nature whose balance has been disrupted by humans (modified forest).

Scott (1999) argues that with the advent of scientific forestry, the state began to conceptualize the forest as a one-commodity machine. Through its documentary practices, the state focused on foregrounding the forest's ability to generate timber revenues for state coffers. Scott traces how state officials abstracted from the on-theground biological complexity and myriad local uses of the forest in order to produce a synoptic and technical view of its timber potential. This took the form elaborate tables of tree age, size and expected maturation and maps. These representations amplified the characteristics of the forest the state was most interested it - its ability to produce timber.

\section{Image Analysis}

I draw from the literature review presented above in my analysis of the Corps's documentary practices. As I stated previously, I selected three maps and images from the Corps' 2009 Tamiami Trail project factsheet for analysis. Following Braun (1997), I use discourse analysis to reveal how these three images frame the Everglades by attending to what is present in and what remains "unmarked" in or absent from them. These images are displayed below as Figures 3, 4 and 5. 
Figure 5. Schematic Map of Tamiami Trail Project

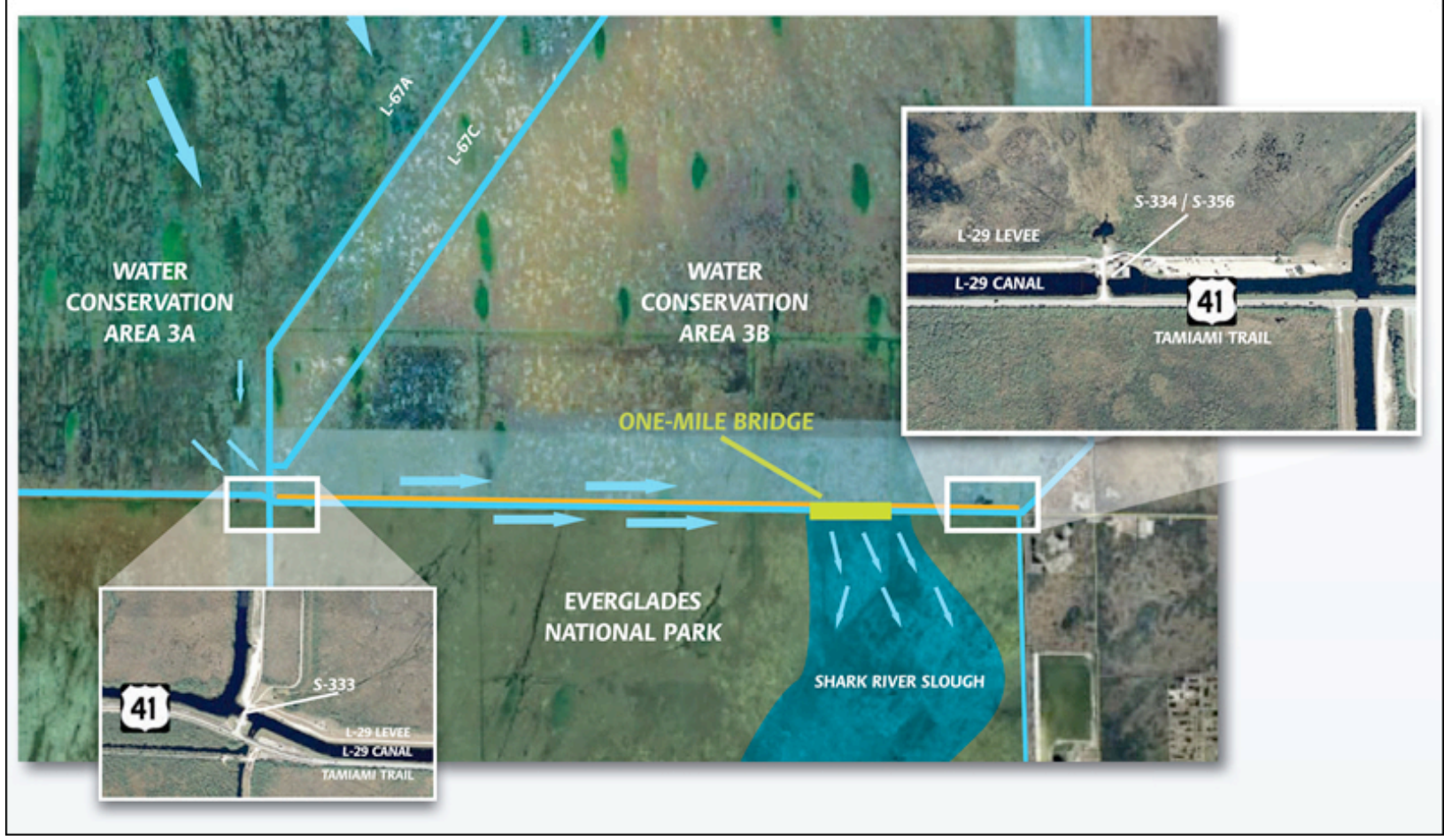

Figure 4. Illustration of Tamiami Trail Before One-Mile Bridge Implementation

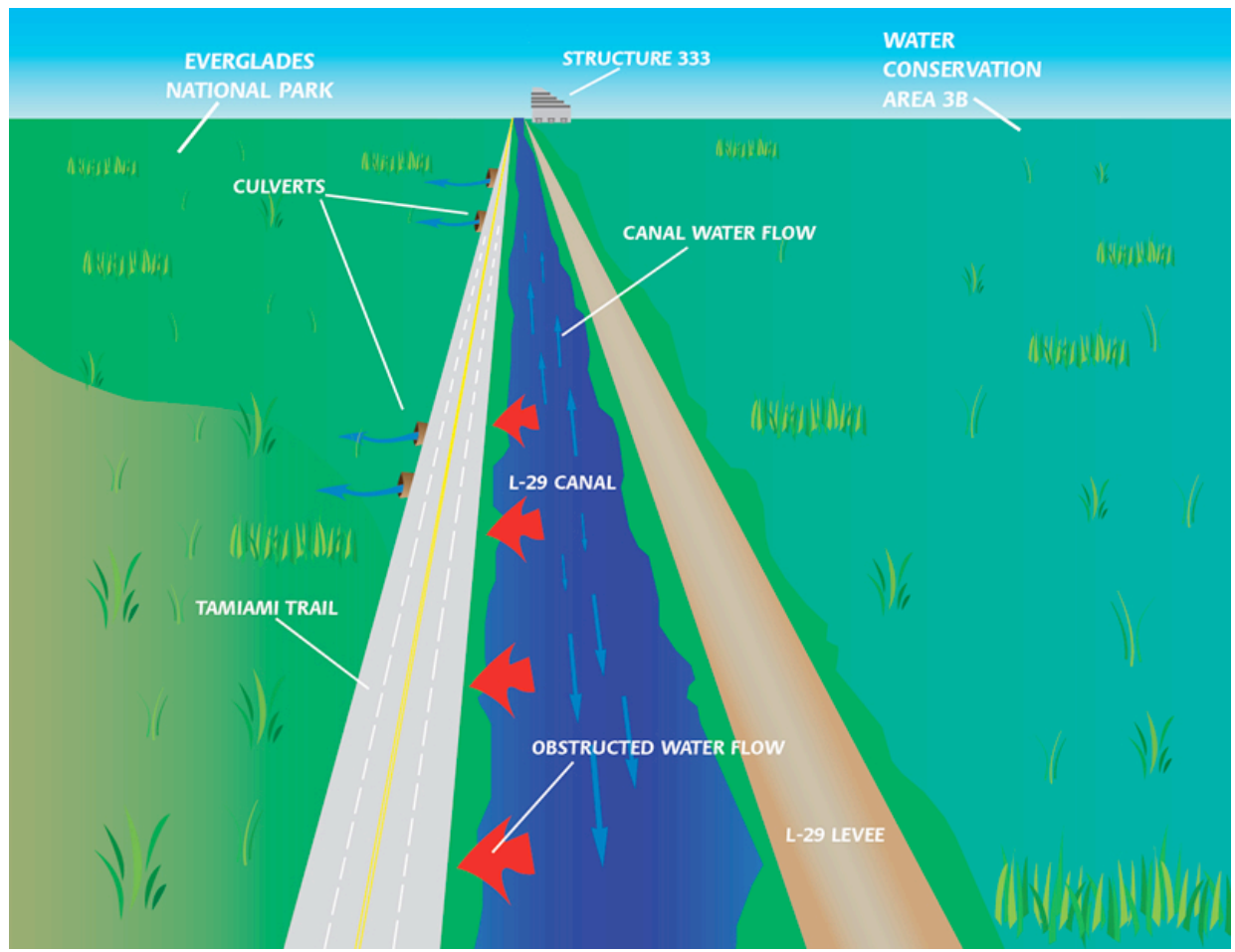


Figure 5. Illustration of Tamiami Trail After One-Mile Bridge Implementation

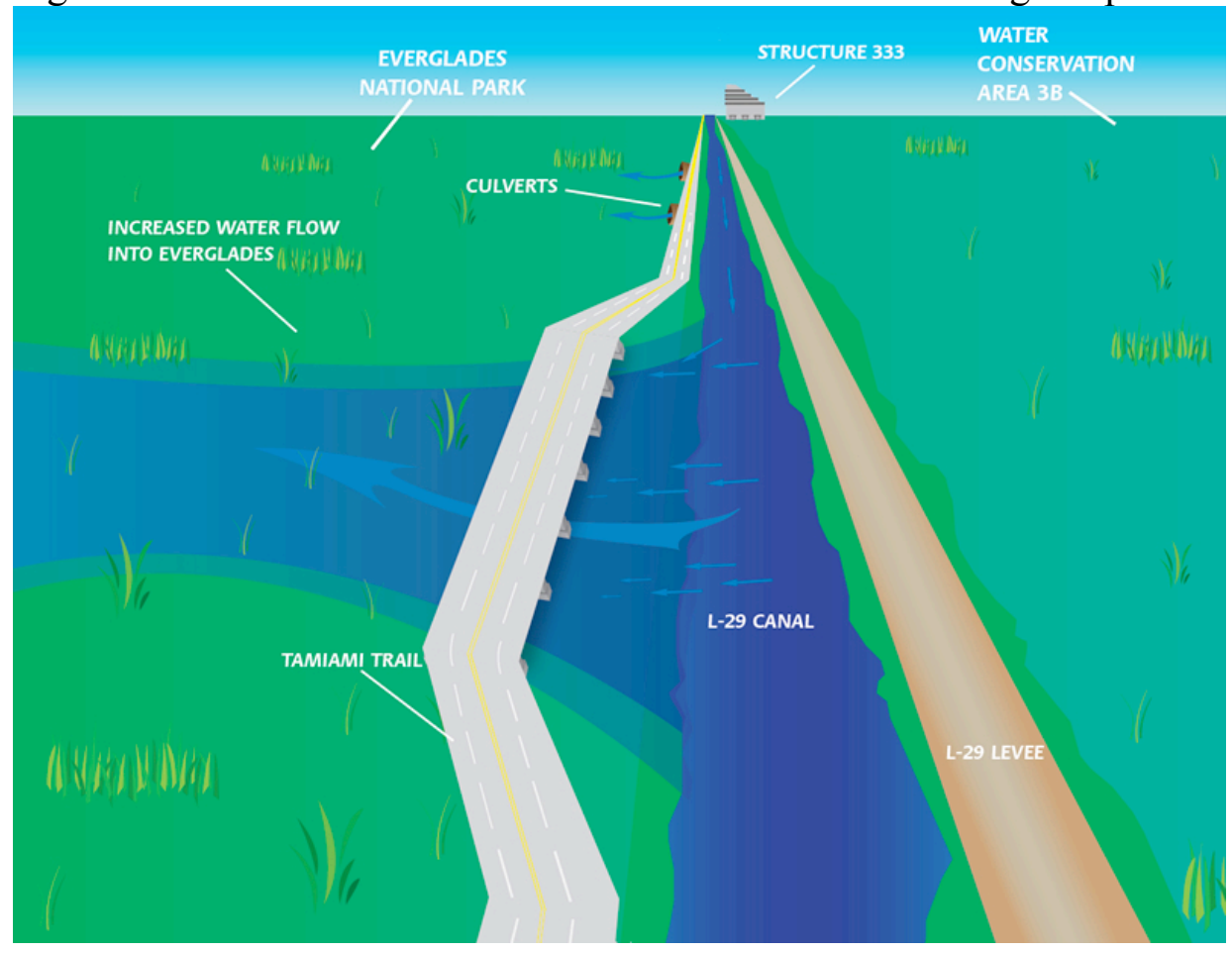

Clearly, these images are inscriptions. They convert the three-dimensional reality of the Tamiami Trail project into two-dimensional paper-based representations. These inscriptions results from multiple acts of translation. Like the Sierra Club/Wilderness Society Map that Braun discusses, Figure 5 is a composite of satellite imagery, water flow schematics and project features made possible by a network of Corps employees and machines, including Corps engineers, project managers, communications specialists as well as computers and satellites. Figures 4 and 5 are clearly illustrations, but they too are the products of Corps networks of employees and machines.

Two key observations can be made about what these images reduce and what they amplify. All three figures foreground the Everglades a space of pure and unpeopled nature ordered by key engineering features. For example, only natural and engineering 
features are named in the figures. There are two key Miccosukee Tribe of Indian settlements - the Tigertail and Osceola camps - and three well-known recreational airboat facilities along the stretch of U.S. 41 displayed in Figure 5. All of these actors inhabit the project space and have factored prominently into the long-term negotiations over Tamiami Trail bridging. However, these human landmarks are absent from Figure 5.

This strategic representational maneuver "normalizes the territorial claim of the nation-state" to and authorizes Corps bureaucrats to speak for the Everglades (Braun 2002,43 ) because it purifies the project of competing political and territorial claims (Braun 1997; 2002). Specifically, this representation amplifies a vision of uninhabited nature at the expense of local human claims to this project space.

These representations are also highly conditioned by the institutional imperatives of the Corps. In Figures 4 and 5, the Everglades is portrayed as a collection of discrete natural and engineered features amenable to human intervention. These objects appear to be easy to manage and control. One the one hand, Figures 2 and 3 could be blueprints for home furniture assembly - they clearly delineate the pieces that have to be assembled and/or modified in a before and after sequence. On the other hand, Figure 5 has the look and feel of an engineering plan with its bright blue directional arrows. Ultimately, these images recast nature in a technoscientific form. These images emphasize complete control over nature, but they also command authority by drawing on technoscience. By shifting the conceptual space of the Everglades to engineering, a domain of technoscience, the Corps presents the restoration project at hand as simply a matter of installing a bridge to modify water flows. These images don't acknowledge the highly political nature of this project; they simply cast it as a technical issue. 
These images also embody what the Corps can and wants to do. Historically, the Corps was a powerful federal public works agency involved in building many of the largest and most important infrastructure projects in the political and economic history of the United States (Clarke and McCool 1996). Only recently, has the Corps been tasked by Congress to pursue ecosystem restoration. Moreover, the Corps does not have a stellar environmental record. Called "river killers" in the 1970s and 1980s, the "nation's builders" have constructed many projects that caused environmental degradation (Clarke and McCool 1996). While the Corps' mission has changed, its institutional culture still leans heavily on using engineering expertise to plan and implement infrastructure projects.

\section{Conclusion}

These Corps' images matter because representations (especially dominant ones) inspire real world action. Specific nature imaginaries condone certain social practices or resource management strategies, which shape the physical landscape. James Scott discusses how the state's maps and tables designed to provide information about timber yield, were used to cultivate a Normalbaum, monocultural forest in reality. As Ferguson observes, development "problematics" are not just fictions used "to obtain funding or justify projects at high levels" $(1994,74)$ but exert real influence over day-to-day institutional practices, programs and projects. In addition, while not direct representations of reality, maps often become important actors in natural resource struggles. Braun (2002, 216-217) charts how the Sierra Club/Wilderness Society map of the "disappearing ancient forest" restructured the power relations among players in the debate over B.C. 
forest management and galvanized new constituencies into action to save the temperate rainforest. Representations such as the maps and images discussed above are powerful "artifacts of discourse and practice that can be analyzed for enabling conditions and founding presuppositions" (Braun 2002, 254). These objects also have a cultural and material productivity that extends far beyond the pages/papers on which they appear. 


\section{REFERENCES}

Braun, Bruce

1997 Buried epistemologies: The politics of nature in (post)colonial British Columbia.

Annals of Association of American Geographers 87(1): 3-31.

2002 The intemperate rainforest : nature, culture, and power on Canada's west coast.

Minneapolis: University of Minnesota Press.

Clarke Jeanne N., and Daniel C. McCool

1996 Staking Out the Terrain: Power and Performance among Natural Resource

Agencies. Albany: State University of New York Press.

Committee on Independent Scientific Review of Everglades Restoration Progress (CISRERP), National Research Council, National Academy of Sciences

2008 Progress toward restoring the Everglades: The second biennial review. Washington, DC: National Academies Press.

Cronon, William

1995 The trouble with wilderness: Or, getting back to the wrong nature. In Uncommon Ground, ed. William Cronon, 69-90. New York: Norton.

Doyle, Mary

2008 "The Everglades." In Large-scale Ecosystem Restoration: Five case studies from the United States, eds. Mary Doyle and Cynthia Drew, 1-2. Washington, DC: Island Press.

Escobar, Arturo

1995 Encountering Development. Princeton, NJ: Princeton University Press.

Ferguson, James

1994 The Anti-Politics Machine. Minneapolis, MN: University of Minnesota Press.

Latour, Bruno

1986 Visualization and cognition: Thinking with eyes and hands. In Knowledge and

Society: Studies in the Sociology of Culture Past and Present, eds. Henrika Kulchek and Elizabeth Long, 1-40. London: JAI Press.

1999 Pandora's Hope: Essays on the Reality of Science Studies. Cambridge, MA: Harvard.

U.S. Government Accountability Office (GAO)

2007 South Florida Ecosystem Restoration Is Moving Forward but Is Facing

Significant Delays, Implementation Challenges, and Rising Costs. Report for House Committee on Transportation and Infrastructure. Washington, DC: GPO. GAO-07520 
Gregory, Derek.

1994 Geographical Imaginations. Cambridge: Blackwell.

Ogden, Laura

2008 The Everglades Ecosystem and the Politics of Nature. American Anthropologist 110(1): 21-32.

Society for Ecological Restoration International Science and Policy Working Group (SER)

2004 The SER International Primer on Ecological Restoration. Tucson, AZ: Society for Ecological Restoration International.

South Florida Ecosystem Restoration Task Force (SFERTF)

2000 Coordinating Success: Strategy for Restoration of the South Florida Ecosystem. Miami: South Florida Ecosystem Restoration Task Force. 


\section{Chapter 6: The Cultural Politics of Nature - The Rise of the Gladesmen Folk Culture in the Florida Everglades}

\section{Prelude}

This chapter begins with John. I am standing on an airboat bow that hovers over the glassy shallow waters of a sawgrass prairie deep in the Everglades marsh. John is its driver. An energetic outdoorsman with sun-weathered skin, John has spent countless hours navigating this mosaic of sedges and tree islands in his airboat, hunting frogs (a practice known locally as frog gigging) and skimming across the shallow waters between backcountry camps. To underline his intimate knowledge of this place, John tells me that I could drop him off in the middle of the Everglades and he would be able to find his way out without GPS, surviving by his swamp know-how alone - a common refrain among self-defined gladesmen. Our conversation turns to the Gladesmen Culture, a new way of talking about and naming people like him with a longevity in this waterworld. I ask him why he and other swampers have started using this term.

He tells me: "We saw the power of culture at work for the Indians. Me and others were initially using the word recreation for a while, but we realized it was a comparatively weak word. It didn't inspire the same kind of power and clout as 'traditional use.' We had to make them aware of our culture."

\section{Introduction}

Environmental conservation projects, including ecosystem restoration initiatives, remake people and landscapes across the globe. While claiming to protect and rehabilitate landscapes deemed ecologically valuable, these projects create a certain 
cultural politics of belonging and recognition because of the ways they reimagine "proper" human-environment interactions in culturally specific and power laden ways (Hull and Robertson 2000, Higgs 2003, Kosek 2006, West 2006, Li 2007). Thus, these projects usher in virtualizing visions (Carrier and West 2004) about what people, species and uses belong in these conservation landscapes, giving rise to new kinds of what $\mathrm{Li}$ (2007) calls environmental "trustees", and on-the-ground projects to realize these conservation visions, often to the detriment of local peoples (Neumann 1998; West 2006; West, Igoe and Brockington 2006; Ogden 2011).

In this chapter, I explore how spaces of belonging are produced and contested in the emergent conservation landscapes of the Florida Everglades, and how tensions over whose heritage counts in this water world have given rise to a new identity, the Gladesmen culture. Building on my analyses in Chapters 4 and 5, I explore how heritage discourses and debates over public land stewardship in the Florida Everglades have produced a space of alterity whereby the landscape meanings, claims and histories of white outdoorsmen are marginalized. Specifically, the creation of over 2 million acres of public lands in the southern Everglades and the reframing of the Everglades as "America's Everglades" through the Comprehensive Everglades Restoration Plan have prompted conflicts over belonging as the landscape's importance as a national conservation landscape has overshadowed its local cultural values. These marginalizations by the state and environmental NGOs - what Bruce Braun terms "constitutive absences" $(2002,9)$ - have created conditions for the formation of an 
oppositional and political identity, the Gladesmen culture ${ }^{1}$. The Gladesmen culture is focused on promoting the reterritorialization ${ }^{2}$ (and a greater recognition) of white outdoorsmen's voices, claims and forms of access in debates over the Everglades.

I explore how some white outdoorsmen, spurred by key events and realizations over time, began a focused campaign to reassert their belonging, mobilizing behind a new identity marker, the Gladesmen culture. The Gladesmen culture served as a way of calling attention to and authenticating their place-based heritage (reinscribing the local and the human into more global visions of a pristine Everglades). Yet, as I document in this chapter, the Gladesmen culture is a relatively new concept, emerging from decades of cultural politics in the Everglades. Specifically, I argue that the Gladesmen Culture is an example of an emergent and politicized collective identity strategically articulated by white outdoorsmen to re-establish the visibility of a particular kind of socio-historical whiteness (local heritage) in the Everglades.

My research combines the insights of several literatures: environmental anthropology's examination of the sociocultural dimensions of environmental conservation projects, and the literature on cultural heritage and cultural authenticity. Building on this scholarship, I discuss three key points. First, drawing on documentary and ethnographic evidence from my dissertation research, and building on my analyses in Chapters 4 and 5, I document the specific conditions of formation for the oppositional

\footnotetext{
${ }^{1}$ The erasure of certain communities of people and their attachments to place in representations of nature, is what Bruce Braun terms a "constitutive absence" $(2002,9)$ designed to make a particular imaginary or fiction of nature into a reality. In this way, nature imaginaries - representations of nature - are political projects where "what counts as [nature] is an effect of power" (Braun 2002, 9).

${ }^{2}$ Here I understand reterritorialization as more than the reclamation of legal rights to land. Reterritorialization is a politically-driven form of emplacement whereby a community of people strive to
} 
Gladesmen identity and how it is linked to the shifting landscape politics of Everglades protection and restoration. I also trace how the formal recognition and authenticity of this oppositional identity are linked to the role of the National Park Service as an arbiter of culture (it is the overseer of the National Register of Historic Places). In this way, I show how the state (as a disparate array of agencies) produces both dominant and counterheritages in the Everglades. Finally, I detail how the Gladesmen identity works, reshaping media coverage to create a space of self-representation and empowerment. In this context, I attend to how the Gladesmen culture creates consensus and contestation because outdoorsmen and others don't uniformly embrace or accept this identity. I also comment on how the Gladesmen identity is premised, in part, on unsettling the authenticity of other Everglades actors. I close my paper with a summary of my main points and theoretical contributions - namely, I focus on how the Gladesmen culture effectively decenters the discursive space for Everglades heritage created by ENGOs and the state while simultaneously looking to the state, as an arbiter and steward of the nation's cultural resources, to authenticate their counter-heritage and claims to place under the National Register of Historic Places (NRHP).

\section{Landscape Politics and Culture Collide: The Gladesmen Identity Emerges}

As I detailed in Chapter 4, the National Park Service's (NPS) Big Cypress

National Preserve is an example of the Everglades landscape politics that have given rise to the Gladesmen culture. I described how creation of the Big Cypress National Preserve in 1974 changed the Big Cypress from a local cultural landscape into a conservation

regain access to and use of lands and waters that form the basis of their identity; and to reinscribe their 
landscape seen through bureaucratic optics and logics that privilege hydrology, charismatic mega fauna and pristine wilderness. I showed how this emergent (yet virtualizing) conservation vision and its concomitant administrative and land management framework positioned environmental NGOs (ENGOs) and the NPS as Everglades spokespeople, while marginalizing white outdoorsmen's place in the landscape and, at best, re-presenting them through the contemporary frame of reference associated with off-road vehicle (ORV) use: as reckless thrill seekers external to the landscape who destroy and degrade it. I argued that this new conservation vision effectively shifted the politics of belonging in ways that that materially and discursively displace outdoorsmen from the Everglades.

Outdoorsmen's frustrations have only grown with the inception of the Comprehensive Everglades Restoration Plan in 2000 - a program they believe is more focused on water than people. To them, CERP has become a symbol of the federal government's over-spending, unnecessary largesse and lack of regard for local people. The majority of outdoorsmen I spoke with see Everglades restoration as a plan to store and move water across the Everglades, which neglects to provide access to people who historically used those areas. They believe the government wants to turn wetlands and uplands once used by outdoorsmen into reservoirs, and that these reservoirs won't serve local interests and will ruin game habitat.

One outdoorsman, who has hunted and spend time in the Everglades since he was 21, told me: 
We kept sayin' make all the [CERP] canals people and wildlife-friendly. Don't just think of 'em as conveyances to move water. So, you understand the structural difference between that? Wildlife-friendly means you're gonna have banks, littoral zones. Conveyance means you're just gonna have a square cut canal. People-friendly means you're gonna have boat docks and ramps in places, parkin' lots, okay? And, they wouldn't do it...In the first plans comin' out from the [US Army] Corps [of Engineers] about how they were restructuring the water plumbing - [they] had no parking lots. Had no way to get to the canals. Had no way to get to the woods, it was another wall. And, that's why I created the Water Resource [Advisory] Commission's recreation subcommittee [at the South Florida Water Management District].

Another outdoorsman articulated:

A lot of people think that if it's for the Everglades, it's good. But it isn't so. My impression is that Everglades restoration is setting up water supply for the next two to three million years. It's going to change the demographics of wildlife by filling [the Everglades] up with water. If [the government] would just say it - you are going to put water into impoundments and going to change the Everglades kind of like into a sewage treatment plant. Those are good things for the alligators. But it's different; I'm biased toward deer. With the Headwaters project going on now, [I'm convinced the government] wants to hold water and store water in every depression on the Florida landscape.

The Gladesmen identity has emerged from outdoorsmen's larger frustrations about being marginalized in the new space of environmental trusteeship created by federal NPS land management and CERP. This oppositional identity can be linked to a broader narrative outdoorsmen tell about how they have lost territory and influence in the Everglades. Interviewees have recounted to me their longstanding grievances over what they term the loss of traditional use and access in the southern Everglades (to lands they claim that they and their ancestors historically hunted, fished and travelled across) and 
their frustrations over how to fight back in a representational space seemingly dominated by environmental organizations and the National Park Service. Gladesmen and outdoorsmen typically attach their story to or invoke "a complex of injustice" beginning with creation of Everglades National Park (and what it took from local people), a history that many of these men and women did not experience firsthand, and is mythologized in certain key ways. In their minds, the designation of Everglades National Park in 1947 first fomented local grievances over use and access while the Big Cypress National Preserve became the next big battleground. Outdoorsmen will name off other lands they have been pushed out as well including the Loxahatchee National Wildlife Refuge.

While there are disparate histories surrounding these public lands and different government agencies involved, outdoorsmen have melded these public lands into one narrative about what the federal government does: it pushes you out and locks you out of its protected area, even if it says it won't. One women made her indignation known at a Florida Airboat Association meeting I attended, asserting: "They [the federal government] are destroying our culture and our way of life. We have to stop them."

Outdoorsmen and women harbor a deep distrust of the government and environmental NGOs, which outdoorsmen often refer to as the "antis," because of what they say has happened in the Big Cypress and because of their own personal experiences where they were misled by government agencies about government intentions for Everglades projects. In their view, the government and ENGOs promised outdoorsmen that they would forever have a place in the Big Cypress National Preserve, but instead outdoorsmen feel they are being incrementally pushed out with more and more regulation. Outdoorsmen believe that instead of honoring earlier promises and 
agreements, the NPS (until lately) and environmental organizations have worked to squeeze them out of the Preserve at every turn. Outdoorsmen expressed a profound sense of loss - that their way of life is being lost. They believe the federal government just wants to continue to take from them until they have disappeared from the landscape (eliding the critique of widespread land development).

Many outdoorsmen have recounted to me how, at first, the power of the federal government seemed both sweeping and perplexing, and the new voices of other public land constituencies very loud. Initially, outdoorsmen weren't savvy about how to participate in federal decision-making processes, how to make their practices and knowledge visible to the state, or how to generate effective press to counter narratives about their supposedly uniformly destructive behavior. Locals were poorly organized and inexperienced. As one interviewee and long-time hunter told me, " [initially] the Preserve regarded us as a bunch of crackers and rednecks" (Interview September 21, 2011). As one interviewee explained to me, outdoorsmen were people who wanted to be left alone and spend time in the woods not become professional advocates (Interview September 26, 2011). They had to "get educated" and acquire the technical savvy to participate in new processes under NEPA for making decisions about land management in the southern Everglades.

In this way, The Gladesmen identity functions in the words of Ana Tsing (2005, 268) as "the strategic transformation of local identity to enter a wider conversation" - in this case, about reinscribing people into Everglades restoration projects and federal land management activities, reclaiming physical territory and pushing back against the trusteeship of state agencies and ENGOs. 
The roots of the Gladesmen identity, as the formal marker of a contemporary collective cultural identity, can be traced back to one person: Dan. Dan grew up in a Miami suburb called Hialeah. In his youth, he began hunting along U.S. 27 when the stretches of Everglades closest to Miami were still wild. Dan was an amateur when he began hunting and perfected his hunting skills by talking to and watching other outdoorsmen. As he told me, "The Glades can draw a very mischievous kid off the wrong road should he get on it" (Email, October 24, 2012). Dan has spent almost 40 years of his life hunting in the Everglades. He participated in the infamous mercy deer hunts of the 1970s in the Water Conservation Areas during extremely high water periods. In the 1990s, he began spending more time in the Big Cypress National Preserve. By that time, Dan didn't trust "the government." He and his friend had an earlier run-in with Everglades game wardens who, according to his account of the situation, forged a violations ticket that landed his buddy in court. He was also deeply disturbed by the construction of a 10-foot tall fence along I-75, which blocked accessed into that region of the Everglades. Dan felt the Everglades was changing for the worse under the trusteeship of "the government". He came to believe the government's activities in and around the Big Cypress National Preserve merited scrutiny and oversight, so he decided to keep an eye on things. Dan was not politically active until about 1995 or 1996 when he got involved with the Tamiami Trail Scenic Corridor initiative, a committee that was working to designate U.S. 41 as a scenic highway. Dan attended numerous public meetings, and began to learn more about the federal decision-making process. Through his participation, Dan realized that environmental impact statements for federal projects required historical surveys, in compliance with Section 106 of the National Register of 
Historic Places. He started a dialogue with one of the project historians about where his own ties to the landscape fit in to the bureaucratic and documentary landscape of Everglades nature.

Dan continued to participate in federal project meetings in the southern Everglades, and to relay his findings back to a larger group of politically active outdoorsmen. During the preparation of a different environmental impact statement for a CERP project designed to bridge the Tamiami Trail, Dan raised the concern that the project ignored the "common architecture" of the Airboat Association of Florida in its survey of historical and cultural properties. For a variety of reasons, the US Army Corps of Engineers ended up reconfiguring this project. The Corps' project redesign prompted a supplementary EIS under NEPA and another cultural survey. The turn of events created an opening for additional information, and Dan was asked to do an interview with a project historian from the consulting firm in charge of the cultural survey. Dan says she came to his house and that during the course of their interview she told him that she believed he and other outdoorsmen were an identifiable culture and that the whole Everglades was a cultural property. She shared National Register Bulletin 38, "Guidelines for Evaluating and Documenting Traditional Cultural Properties," with Dan, which he says, "got us thinking more." Moreover, her project report examined the cultural significance of the Tamiami Trail roadway as a Traditional Cultural Property (TCP) through ethnographic interviews. While her study concluded that the Tamiami Trail didn't qualify as a TCP, it recommended that the US Army Corps of Engineers undertake further ethnographic study of the relationship between the Everglades and different cultural groups including outdoorsmen. Such an investigation was merited, she 
concluded, to determine if specific locations within the Everglades as well as if the Everglades as a whole would qualify as TCPs. Dan described how his conversations with this historian, and her study, opened his eyes to the idea that he and other outdoorsmen had a culture that needed to be documented. This idea made sense to him. Dan put it this way,

For a long time, due to the serious concerns I had for years over access and hunt rules as well as the deep concerns of many others, I knew our involvement was too deep to be just because of hunting...I think we all knew there was something bigger at stake but just didn't have the formal education to pinpoint what it was. Eventually we got it - we were a culture.

The historian also emphasized to Dan that she believed there were ethnographic communities in the Big Cypress National Preserve and that the NPS was required to document them per NPS Directive 28. Dan emphasized, “After I read [Bulletin] 28, I started raising cane with the Big Cypress National Preserve. [I said] what they are doing is cleansing the culture out of the area. [The NPS] want[s] it to look like it did in 1200 A.D. [They] want to remove any sign of mankind from the land they manage..."

The Big Cypress National Preserve did not conduct a comprehensive ethnographic overview and assessment under the NRHP guidelines. But Dan persevered. Dan recounted to me that he realized: "If we had a culture there were [Traditional Cultural Properties] TCPs out there. [It] just got me thinking and I received additional guidance from a historian friend.“

Dan and other white outdoorsmen recognized the power of cultural claims in carving out a space of belonging in the new bureaucratic and documentary landscapes of 
the southern Everglades, and in framing debates about natural resource management. They saw the power of culture at work for the Native American tribes in the Everglades. Another long-time outdoorsmen underscored how white outdoorsmen saw that once a culture is formally identified and recognized through government channels, government agencies have to deal with it in their decision-making (Phone Conversation September 2, 2011). The politics of recognition associated with the National Preserve as a conservation landscape were also becoming increasingly clear. As one respondent told me, Gladesmen weren't the ones getting articles in the newspaper. Instead, environmentalists were shaping the terms of debate and public perceptions using newspapers as far away as the LA Times (Interview September 26, 2011). That had to change. As several interviewees emphasized, outdoorsmen had to find a way to capture the public imagination and shift public perception. They saw culture as a way of describing and reframing their presence in the Everglades, especially because they didn't have official tribal recognition, blood quantum or exotic dress as markers of their native status (Conklin 1997). Yet, Gladesmen also recognized how important official reports and government recognition were, in this arena of bureaucratic maneuvering, to establishing the authenticity and existence of their culture.

The push for formal recognition of the Gladesmen culture and a study of its TCPs under the NRHP came through the CERP Master Recreation Plan (MRP). The MRP was an idea initiated by outdoorsmen through the Recreation Subcommittee of the Water Resources Advisory Committee. Outdoorsmen wanted to ensure recreational access was considered as part of all CERP projects. In 2006, Dan wrote a letter to the US Army Corps of Engineers, the supervisory agency of CERP and the MRP, asserting that the 
MRP was in violation of Section 106 of the National Register of Historic Places because it had failed to assess the project's effects on Traditional Cultural Properties associated with the Gladesmen culture. The Corps reviewed Dan's letter and concurred. A Corps archaeologist was assigned to the project and he hired a consulting firm to conduct a formal ethnographic study: "You Just Can't Live Without It. Ethnographic Study and Evaluation of Traditional Cultural Properties of the Gladesmen Culture.” This study sought to identify Traditional Cultural Properties associated with the Gladesmen Culture and determine the eligibility of these sites for listing on the National Register of Historical Places (NRHP). This study was completed in the summer of 2011 and recommended two sites for listing on the NRHP: Mack's Fish Camp and the Airboat Association of Florida. Moreover, the study defined and affirmed the presence of a modern Gladesmen Culture in the Everglades, positioning it as a variant of the southern "cracker" culture that had adapted to the particulars of south Florida's wetland environments. The report provided white outdoorsmen with the opening they needed to reassert their claims and reestablish their own space of belonging in the Everglades. In the eyes of many outdoorsmen, the study firmly established the Gladesmen Culture as an authentic culture with a distinct history and heritage. White outdoorsmen also saw the study as a device that would deliver more clout and recognition in their environmental struggles over the Everglades.

The term "Gladesmen Culture" was in circulation at public meetings related to Everglades land stewardship even before the master recreation planning process. It likely first appeared around 2005 as important marker of a swamp-based identity and practices in discussions over the management of the southern Everglades. The descriptive 
"Gladesmen" came from Dan's efforts to brainstorm an appropriate name or "brand" for the culture. Dan recognized the need to counter negative public perceptions about white outdoorsmen and to carve out a representational space, or brand, that would elevate the swamp way life as a culture, and make it more visible (get newspaper articles written). He knew that outdoorsmen needed a marketing strategy of their own. He told me how he thought and thought about the right name, and then saw a copy of the book Gladesmen by Glen Simmons and Laura Ogden on his bookshelf. "The light went on," Dan informed me. After that, Dan began to heavily lobby outdoorsmen and their advocates to use this term to create a catchy and recognizable overarching identity in the public sphere (Interview September 26, 2011).

Folk life literature first brought the term Gladesmen into the public imagination through Glen Simmons and Laura Ogden's book, "Gladesmen” (1998). Simmons and Ogden's book detailed the pioneer life and practices of a well-known white alligator hunter who subsisted in the southern Everglades' backcountry before the establishment of Everglades National Park. This book posited the term Gladesmen as a way of referring to a distinct cultural group of white pioneers who subsisted off the land in the southern Everglades. Ogden's use of this word was political and anthropological. Ogden describes how she came across this term in a letter during archival research at the Loxahatchee National Wildlife Refuge and wanted to use it to signify a rural white culture, and use it to prompt wider publics and state agencies to recognize that culture.

Outdoorsmen's push to establish a Gladesmen culture both in the public imagination and through official state recognition is fueled, in part, by a desire to reinscribe the human into an Everglades landscape that has been reduced to an amalgam of 
water, flora and fauna by the federal and state agencies who manage it, and to call attention to the Everglades as a cultural landscape. Specifically, it calls attention to a place-based community of people whose identity is deeply linked to this landscape and to certain failings in government agencies' trusteeship - their inability or reluctance to see the human history of the Everglades. In fact, this is the first ethnographic study conducted to date under the umbrella of Everglades restoration and points to clear deficiencies on the part of government agencies in documenting the ways the Everglades landscape is meaningful to different communities of people (Corps 2009) ${ }^{3}$. Yet, the Gladesmen culture is also an overtly political identity aimed at reterritorializing and validating greater motorized access of all kinds across the Everglades. Some of its proponents link the Gladesmen culture and its survival to a dependency on unfettered vehicle exploration and access. They advance the idea that when the NPS or other government agencies minimize ORV trails or ORV access, they are destroying a culture. In this way, there is no doubt that the Gladesmen identity is also propelled, in part, by nostalgia for a mythologized past when people and their motorized vehicles had the freedom to traverse the Everglades as they pleased (a past that doesn't fit well within the present multi-use landscape, and is based on its own selective history which excludes other human histories such African American loggers and poor rural "crackers who worked in the logging industry as well as Native American uses of this same landscape).

\footnotetext{
${ }^{3}$ In fact, a Corps archaeologist told me that the Corps has asked the Native American tribes in the Everglades to identify TCPs, but that they have refused, citing confidentiality concerns.
} 


\section{How the Gladesmen Identity Works}

\section{Self-Representation}

Using the Gladesmen Culture, a handful of white outdoorsmen, spearheaded by Dan, are slowly reshaping the representational space surrounding the Big Cypress National Preserve and the Florida Everglades so that these spaces reaffirm (rather than erase) their belonging in the Everglades. The creation of the Gladesmen Folk Culture has attracted media coverage of its own. The first article about gladesmen trying to protect their way of life in the Everglades came out in approximately 2007 in the Broward New Times (Francis 2007). Additional articles followed, many of which explore the rural Gladesmen way of life and the struggles to maintain it (Eifling 2008, Klinkenburg 2012). In fact, in 2011 Miami's public radio station $W L R N$ did a full-length feature on the Gladesmen culture. WLRN's story featured Dan and Mack's Fish Camp - one of the TCPs recommended for listing on the NRHP - and touched on the Gladesmen's unique lifestyle in the Everglades, their renegade spirit and on how Everglades restoration will change the landscape Gladesmen know and love. Other articles about Gladesmen and their unique Everglades practices have appeared in newspapers as far away as the Bellingham Herald (Cocking 2011). Outdoorsmen now invoke frequent references to the Gladesmen culture in public meetings and on online comment boards linked to newspaper articles about Everglades projects to make their cultural claims more visible and meaningful. In fact, a website started by a Big Cypress backcountry camp owner to promote a better understanding of the people and critters who frequent the Big Cypress Swamp makes specific reference to the Gladesmen Culture (see bigcypressswamp.com). I have watched people refer to themselves as gladesmen at public meetings. At the October 
2011 meeting of the Big Cypress ORV Advisory Committee meeting, several committee members called themselves gladesmen during introductions (Fieldnotes October 18, 2011) to make clear their deeply personal and emplaced ties to the Big Cypress National Preserve forged through years of hunting and travel throughout the swamp.

\section{Fragmentation and Contestation}

Yet, the Gladesmen identity is also fragmented and contested. It is not universally accepted across the community of outdoorsmen. Many of the outdoorsmen I spoke to in the backcountry of the Big Cypress National Preserve (away from the political discussions and meetings rooms where decisions about Preserve management are made) were ambivalent about this term. I conducted a structured survey of hunters and swamp buggy users at several access in the Big Cypress National Preserve during the month of December 2011. Moreover, I took several trips into the Preserve with outdoorsmen to visit backcountry camps, riding on their swamp buggies. During these exchanges, when I asked outdoorsmen if they considered themselves Gladesmen most of them would say, "Sure, I guess. I spend a lot of time out here." This response underlined that many of these men don't overtly self-identify as gladesmen but will if asked. I also encountered some opposition to this term. One camp owner and hunter told me that he didn't believe there were any more gladesmen because outdoorsmen were no longer able to make a living off the land. He told me,

Gladesmen? I've heard it but not in this day and time. [It refers to] old guys who would start at Ochopee and go all the way north of I-75 before there was I-75. They would go out for a month. I don't think there are true Gladesmen 
today. Like us, we come out during the weekend for threeday trips during hunting season. Of course, in those days there wasn't the law there is now. You could live off the land and shoot what you needed to get by, like curlew.

Another long-time hunter who knows the Big Cypress like the back of his hand scoffed at the term, asking me mockingly "Gladesmen, what is that?" While visiting with a group of long-time outdoorsmen at their backcountry camp deep inside the Preserve, they told me: "We are swampers, not gladesmen. 'Glades' is a citified way of talking about the Everglades. If I said I am going to the 'glades,' I am going to go airboating or go to the sawgrass. If I am coming to the Big Cypress, I am 'going to the woods."” Another man chimed in, “It's been in the books but it isn't what local people call themselves. It's a writer's term." A fifth generation Floridian whose family owned land in the Big Cypress Swamp before the National Park Service bought it from them, told me that he doesn't understand or relate to the Gladesmen identity. He considers this term inauthentic and a bit silly. He told me that he self-identifies as a Florida cracker, and explained that his family and other crackers that he knows who owned land in the Big Cypress sold their land to the government, moved to other lands they owned further north and no longer make claims to the Big Cypress. He told me, "The people calling themselves Gladesmen are not our people." His comments point to the fact that there are other white histories tied to the landscape of the southern Everglades, which get obscured by the Gladesmen narrative. 


\section{Unsettling the Authenticity of Others}

During public meetings and in their discussions with me, Gladesmen and other outdoorsmen concerned about access issues, attempted to unsettle the positions of other so-called authentic actors and species who are seen as belonging in the Everglades Native Americans and Florida panthers.

More than ten outdoorsmen told me that the Florida panther no longer exists. The pointed out the irony in the situation, explaining to me that the current big cat people call the Florida panther is actually a hybrid species because the government brought in Texas cougars to breed with the dwindling population.

At a public meeting over the Big Cypress National Preserve hunt plan, one gladesmen sporting a gladesmen mesh cap sparked a conversation with one of the independent Seminoles in the audience. I sat down next to them and proceeded to ask them more about their cultures. At one point in the conversation, the gladesmen turned to the Seminole man and said to him, "My ancestors were here before yours. My ancestors settled Everglades City. Gladesmen were in this landscape before your people." I heard a similar variant of this story from a commercial airboat tour operator.

\section{Conclusion}

This article has demonstrated how white outdoorsmen have responded over time to the conservation vision that casts the Everglades as an unpeopled landscape of water, charismatic megafauna and wilderness, which ORV users have invaded and degraded. White outdoorsmen reject the imposition of this vision predominantly shaped by outside environmental organizations, which denies them a space of belonging in contemporary 
and historic Everglades. Instead, influenced by a series of key events, realizations and individual actions, politically savvy outdoorsmen have devised their own oppositional identity that draws upon a distinct sense of place and heritage, the Gladesmen Culture. And, they have pushed for its official recognition through government channels and media stories. They have created this identity on their own terms and in a way that is effectively reshaping the forms of landscape representation and belonging in the Everglades.

Other scholarly research has explored how local people resist or co-opt essentialized categories of identity superimposed upon them by environmental NGOs, the state and development practitioners as part of environmental conservation projects (Rupp 2011). My work demonstrates how local white outdoorsmen (local people) have forged their own identity from the ground-up to counteract "constitutive absences" (Braun 2002) created by state and ENGO landscape representations that deny them a place in a restored Everglades. Through the Gladesmen Culture, local white outdoorsmen have leveraged their place-based identities and heritages as swamp-goers to reestablish their visibility and claim authenticity as a culturally and historically distinct form of whiteness in the Everglades. This research illuminates how nature acts as an important site for the production of identity in the southern Everglades. In fact, the rise of the Gladesmen Culture demonstrates how environmental conservation projects are productive of new kinds of identities. 


\section{REFERENCES}

Agrawal, Arun

2005 Environmentality. Durham, NC: Duke University Press.

Blake, Nelson Manfred

1980 Land into Water - Water into Land: A History of Water Management in Florida. Gainesville, FL: University Presses of Florida.

Blue Water Network

2001 Environmentalists Intervene in Big Cypress Thrill-Craft Lawsuit. Press Release. March 20. http://www.commondreams.org/news2001/0320-12.htm (Accessed May $11,2011)$

Canedy, Dana

2002 Advocates and Drivers Reach Fork in the Off-Road. New York Times, March 24.

Conklin, Beth

1997 Body Paint, Feathers and VCRs: Aesthetics and Authenticity in Amazonian Activism. American Ethnologist 24(4): 711-737.

Conklin, Beth and Laura Graham

1995 The Shifting Middle Ground: Amazonian Indians and Eco-Politics. American Anthropologist 97:695-710.

Cronon, William

1995 The Trouble with Wilderness; or, Getting Back to the Wrong Nature. In Uncommon Ground: Rethinking the Human Place in Nature, William Cronon ed., Pp. 69-90. New York: W. W. Norton \& Co.

Davenport, John and T. Adam Switalski

2006 Environmental Impacts of Transport, Related to Tourism and Leisure Activities. In The Ecology of Transportation: Managing Mobility for the Environment, John Davenport and Julia Davenport eds., Pp. 333-360. The Netherlands: Springer.

Dominy, Michele

1995 White Setter Assertions of Native Status. American Ethnologist 22(2): 358-374. 
Francis, Thomas

2007 Swamp Theme: Everglades' old guard girds for county park fight. Broward-Palm

Beach New Times. July 26. http://www.browardpalmbeach.com/2007-07-

26/news/swamp-theme/www.wolfgangsvault.com/-1/ (Accessed October 26, 2011)

Grunwald, Michael

2006 The Swamp: The Everglades, Florida, and the Politics of Paradise. New York:

Simon and Schuster.

Helford, Reid

2000 Constructing Nature as Constructing Science: Expertise, Activist Science, and Public Conflict in the Chicago Wilderness. In Restoring Nature: Perspectives from the Social Sciences and Humanities, Paul Gobster and R. Bruce Hull eds., Pp. 119142. Washington, D.C.: Island Press.

Higgs, Eric

2003 Nature by Design: People, Natural Process, and Ecological Restoration.

Cambridge, MA: The MIT Press.

Hodgson, Dorothy

2002 Introduction: Comparative perspectives on the indigenous rights movement in Africa and the Americas. American Anthropologist 104(4): 1037-1049.

Hughes, David McDermott

2006 Hydrology of Hope: Farm dams, conservation, and whiteness in Zimbabwe. American Ethnologist 33(2): 269-287

Hull, R. Bruce and David Robertson

2000 Conclusion: Which Nature? In Restoring Nature: Perspectives from the Social Sciences and Humanities, Paul Gobster and R. Bruce Hull eds., Pp. 299-307.

Washington, D.C.: Island Press.

Jacoby, Karl

2001 Crimes Against Nature: Squatters, Poachers, Thieves and the Hidden History of American

Kosek, Jake

2006 Understories: The Political Life of Forests in New Mexico. Durham, NC: Duke University Press 
Li, Tanya

2007 The Will to Improve. Durham, NC: Duke University Press.

Mitchell, W.T.

1994 Landscape and Power. Chicago: University of Chicago Press.

National Parks Conservation Association (NPCA)

2011 National Parks Conservation Association Files Suit Against Park Service for

Failure to Protect Big Cypress National Preserve in Florida. NPCA Press Release.

October 12.

http://www.npca.org/media_center/press_releases/2011/big_cypress_suit_101211.ht $\mathrm{ml}$ (Accessed October 24, 2011)

Neumann, Roderick P.

1998 Imposing Wilderness. Berkeley, CA: University of California Press.

New South and Associates (NSA)

2006 A Cultural Resources Survey, Tamiami Trail, Modified Waters to the Everglades National Park -GRR/SEIS. Final Report. January 11. Stone Mountain, GA. Technical Report 1272.

2011 You Just Can't Live Without It. Ethnographic Study and Evaluation of

Traditional Cultural Properties of the Gladesmen Culture. Revised Draft. July 17. St. Augustine, FL. Technical Report 1688.

New York Times

2002 Nature Overrun. Editorial. April 4.

Ogden, Laura

2008a The Everglades Ecosystem and the Politics of Nature. American Anthropologist 110(1): 21-32.

2008b Searching for Paradise in the Florida Everglades. Cultural Geographies 15:

207-229.

2011 Swamplife: People, Gators and Mangroves Entangled in the Everglades.

Minneapolis: University of Minnesota Press.

Peters, Sarah

2007 Conservation Groups Take NPS to Court over Damaging Off-Road Vehicle Use in Big Cypress National Preserve. Wildlands CPR Press Release. Dec. 21. 
http://www.wildlandscpr.org/our-news/big-cypress-national-preserve -threateneddamaging-off-road-vehicle-use (Accessed October 25, 2011)

Repanshek, Kurt

2007a Big Cypress: Wilderness or ORVs? National Parks Traveler.April 23. http://www.nationalparkstraveler.com/2007/04/big-cypress-wilderness-or-orvs (Accessed October 26, 2011)

2007b Ruts in Big Cypress, Wilderness And Endangered Species. National Parks Traveler. May 6. http://www.nationalparkstraveler.com/2007/05/ruts-big-cypresswilderness-and-endangered-species (Accessed October 26, 2011)

Rupp, Stephanie

2011. Forests of Belonging. Seattle, WA: University of Washington Press.

Salt, Terrence "Rock," Stuart Langton and Mary Doyle

2008 "The Challenges of Restoring the Everglades Ecosystem." In Large-scale Ecosystem Restoration: Five case studies from the United States, eds. Mary Doyle and Cynthia Drew, 5-33. Washington, DC: Island Press.

Simmons, Glen and Laura Ogden

1998 Gladesmen: Gator Hunters, Moonshiners and Skiffers. Gainesville: University of Florida Presses.

Spence, Mark David

1999 Dispossessing the wilderness: Indian removal and the making of the national parks. New York: Oxford University Press.

U.S. Government Accountability Office (U.S. GAO)

2007 South Florida Ecosystem Restoration Is Moving Forward but Is Facing Significant Delays, Implementation Challenges, and Rising Costs. Report for House Committee on Transportation and Infrastructure. Washington, DC: GPO. GAO-07520

West, Paige

2006 Conservation is Our Government Now. Durham, NC: Duke University Press.

West, Paige, Jim Igoe and Dan Brockington

2006 Parks and Peoples: The Social Effects of Protected Areas. Annual Review of Anthropology 20 (3): 609-616. 


\section{Conclusion - Emerging Landscapes, Emerging Subjectivities: Environmental Conservation and the Politics of Nature in the Florida Everglades and Beyond}

The grand dame of the Everglades, a prolific writer and passionate Everglades defender, Marjory Stoneman Douglas once wrote, “There are no other Everglades in the world" (2007 [1947], 5). While Douglas was correct in her assessment of the landscape's unique ecology, she failed to attend to the multiple, and historically contingent Everglades known to and valued by different communities of people past and present. Her profoundly influential statement, which still informs calls to save the Everglades today, is an example of the kind of environmental boosterism that transforms landscapes into ecologically-valuable objects, but also effaces their local meanings and human histories. Douglas' pivotal book certainly elided the complex ways the Everglades has been transformed by various power-laden improvement projects, and the ways those projects created different forms of social marginalization. As my work has shown, the Everglades is not a space of universal nature, but an ever-changing socio-natural landscape profoundly shaped by south Florida's complex and shifting social and property relations.

Using the analytic of social nature in my dissertation, I have shown that the Everglades is an emergent landscape produced by specific social, technological and ecological imperatives - all with uneven socionatural consequences (Braun 2002, Harvey 1996). The Everglades that appeared in my dissertation was (and is) an ever-changing object of political, aesthetic and economic calculation that has come into being through unique claims-making processes and unequal power relations between humans, plants, animals, technologies and other non-humans. 
My dissertation examined how three key environmental themes - environmental subject-making, environmental governance, and environmental claims-making - intersect with the politics of nature in the Florida Everglades. My research explored how "environmental trusteeship" has emerged and operated in the Florida Everglades, enabling certain forms of environmental claims-making and landscape transformation. As I described in Chapter One, I build on Tanya Li's (2007) work when I invoke the concept of environmental trusteeship in the Florida Everglades as a way of describing those actors who possess the expertise, power or capital at any given time to shape the lives of other humans and nonhumans in the southern Everglades. In Chapter One, I demonstrated how the history of the Everglades is best understood as a succession of improvement schemes - some designed to drain and develop South Florida, some designed to protect its ecological habitats. As I documented, while each improvement project had specific but uneven ecological and social effects, it created an opening for particular Everglades trustees to rise to power and transform the region, while relegating other actors to the margins - a process rife with social and ecological injustice that I have termed the politics of progress.

Chapters Two, Four, Five and Six examined how more contemporary conservation and ecosystem restoration interventions in the southern Everglades, including the creation of the Big Cypress National Preserve and the Tamiami Trail project, have given rise to new forms of environmental subjectivity, environmental governance and environmental claims-making on the part of the National Park Service and environmental NGOs. These projects have ushered in more global, and more ecocentric ways of seeing, valuing and knowing the Everglades, all while creating strategic 
openings for environmental NGOs and the National Park Service to become Everglades environmental trustees. Yet, I also demonstrated how these projects have marginalized the human histories and place attachments of white outdoorsmen, among other local peoples, and have prompted the formation of an oppositional white identity. As I detailed in Chapter 6, the position of environmental trusteeship in the Everglades is perpetually unstable. Claims to trusteeship often provoke counter-claims and contestations, shifting the balance of power among human and non-human actors. In Chapter 6, I detailed the rise of an oppositional white identity on the part of white outdoorsmen in the Florida Everglades, which outdoorsmen have termed the Gladesmen culture. The Gladesmen culture is aimed at re-establishing the visibility of white outdoorsmen's practices, histories and belonging in an Everglades remade by eco-centric and technoscientific discourses about nature. Chapter 6 underlined how struggles over Everglades stewardship and representation have produced new and complex environmental subjectivities, like the Gladesmen culture and other emergent claims to authentic belonging. In this way, my work illustrates that just as different forms of nature are historically produced, contingent and power-laden, so too are different claims to nature. My research on the Gladesmen culture and the social geographies of the Big Cypress region further demonstrates how identity politics are an integral part of and shaped by environmental struggles in the Everglades.

In Chapter Three, I explored the complex histories and place attachments of white outdoorsmen to the Big Cypress region. In this chapter, I showed how white outdoorsmen with close ties to this landscape, past and present, are a diverse community with deep and longstanding ties to the Big Cypress region. I also argued that the Big Cypress region is a 
landscape of tremendous social complexity, describing how complex property relations and class dynamics have shaped its politics. In addition, I called attention to the ways diverse communities of white, African American and indigenous people have interacted with and reshaped the Big Cypress region. In fact, many of these complicated stories have yet to be told and merit additional scholarship. In this way, as Chapter Three and Chapter Six document, the complexities of whiteness, class, and identity politics in the Florida Everglades cannot be separated from the Big Cypress region's environmental history and its contemporary politics of nature as a national preserve. To paraphrase Jake Kosek (2006), the "sticky and barbed" questions about whose histories, claims to and knowledge about the Everglades matter most become entangled with the "sticky and barbed" questions about South Florida's ecosystem restoration, endangered species and sustainable regional futures.

Ultimately, the politics of identity, the politics of nature and the politics of property are intertwined in the southern Florida Everglades. As I demonstrated in my dissertation, the broader political economy of development in south Florida has shaped the Big Cypress region's history and framed its contemporary conflicts. Development desires, decisions and processes have altered and constrained the Everglades as a socioecological system. In particular, development and environmental conservation processes have caused the rural working landscapes so intimately tied to local practices like those of white outdoorsmen to all but disappear in south Florida. In fact, development decisions and their related processes have reconfigured the south Florida landscape so that today it is highly privatized and intensively developed on both coasts and characterized by predominantly government-owned conservation lands in the middle. What's more, my 
analysis shows how a sophisticated understanding of the specifics of these property relations and land use patterns in the Big Cypress region is crucial to understanding its landscape history, as well as to understanding white outdoorsmen's contemporary sense of place and their environmental claims-making strategies.

\section{Future Research Needs}

This dissertation begins to tell the story of the broader political economy of land use change and its role in shaping environmental conflicts in the southern Florida Everglades. Further, my work suggests how these processes of change are not readily visible. While my dissertation research provided an initial examination of the specifics of property relations and land use patterns in the Big Cypress region, more historical and archival research is needed on this issue. Additional scholarship on the nuances and particularities of the history and lineage of property relations in the Big Cypress region would provide more detail on how contemporary environmental conflicts are linked to historical property relations and development patterns. Specifically, research in the Collier County Property Appraiser's Office on original parcel ownership and subsequent parcel sales, as well as more ethnographic interviews to collect stories about property sales and land use change, would be useful.

My dissertation touched on how the Big Cypress region is a landscape of tremendous social complexity. I briefly described how it has been shaped by complex property relations and class dynamics as well as by diverse communities of white, African American and indigenous people. However, there is a pronounced need to better understand these complex social relations of nature past and present, and to document 
these histories. Moreover, the Big Cypress region was, and continues to be, in many ways development's “other" (Said 1979) but in different ways to different classes of outdoorsmen and south Floridians. It is important for scholars to understand how this place has operated as a diverse oppositional space reflecting how different communities of people have chosen to interact with modern society, and how these motivations and values shape their claims to Everglades nature.

Finally, there is a need for more work documenting the unique federal politics of the Big Cypress National Preserve as the nation's first national preserve. In particular, the following questions arise: How well does the concept of a national preserve align with the National Park Service's Organic Act? What kinds of internal debates and tensions among NPS staff and officials took place over the creation and initial management of the Big Cypress National Preserve? My dissertation provides the basis for a broader future inquiry into how the creation and stewardship of the Big Cypress National Preserve offers important insights into National Park Service history. Moreover, this scholarship serves as an important example of the complexity, nuance and diversity of "the state" in anthropological investigations of environmental conservation projects.

\section{Broader Contributions}

While this dissertation focuses on struggles over environmental conservation in the Florida Everglades, it makes an important contribution to broader scholarship on national parks, property regimes and the politics of nature. My dissertation's stories and findings are directly applicable to conservation landscapes across the globe. Worldwide, parks and protected areas take a variety of forms from private conservation reserves, to 
conservation lands owned by environmental NGOs to government-owned parks (West, Igoe and Brockington 2006). Yet, these conservation areas are all affected by social tensions over land, access and place, and are the products of diverse socio-natural histories (see Brechin et al. 2003). My dissertation provides empirical data to address three of the central questions framing the diverse body of "parks and peoples" literature: "What kind of resource is parkland?," "What role should people play in and around parklands?" and "For whom are conservation projects designed"? 


\section{REFERENCES}

Braun, Bruce

2002 The Intemperate Rainforest : Nature, Culture, and Power on Canada's West Coast. Minneapolis: University of Minnesota Press.

Brechin, Steven R., Peter R Wilshusen, Crystal L. Fortwangler and Patrick C. West, eds. 2003 Contested Nature: Promoting International Biodiversity and Social Justice in the Twenty-First Century. Albany: State University of New York Press.

Harvey, David

1996 Justice, Nature and the Geography of Difference. Wiley-Blackwell.

Kosek, Jake

2006 Understories: The Political Life of Forests in New Mexico. Durham, NC: Duke University Press.

Li, Tania Murray

2007 The Will to Improve: Governmentality, Development and the Practice of Politics. Durham, NC: Duke University Press.

Said, Edward

1979 Orientalism. Vintage Books.

West, Paige, Jim Igoe and Dan Brockington 2006 Parks and Peoples: The Social Effects of Protected Areas. Annual Review of Anthropology 20 (3): 609-616. 


\section{LIST OF REFERENCES}

Agrawal, Arun

2005 Environmentality. Durham, NC: Duke University Press.

Agrawal, Arun and C. C. Gibson

1999 Enchantment and Disenchantment: The of Community in Natural Resource

Conservation. World Development 27(4): 629-649.

2001 Communities and the Environment: Ethnicity, Gender, and the State in

Community-based Conservation. New Brunswick, N.J.: Rutgers University Press.

Barnett, Cynthia

2007 Mirage: Florida and the Vanishing Water of the Eastern U.S. Ann Arbor, MI:

University of Michigan Press.

Basso, Keith

1996 Wisdom Sits in Places: Language and Landscape among the Western Apache. Albuquerque: University of New Mexico Press.

Berg, Bruce

2007 Qualitative Research Methods for the Social Sciences. $6^{\text {th }}$ ed. New York Pearson.

Bernard, H. Russell

2006 Research Methods in Anthropology. $4^{\text {th }}$ ed. New York: AltaMira Press.

Biersack, Aletta

2006 Reimagining Political Ecology: Culture/Power/History/Nature. In Reimagining Political Ecology. Aletta Biersack and James B. Greenberg, eds. Pp. 3-42. Durham, N.C.: Duke University Press.

Big Cypress Papers

1983 Letter from Michael Watkins, President of Coalition of Concerned Citizens, to Secretary of the Interior James Clark, Dec. 7. BICY 14661. Series I, Box 1. South Florida Collections Management Center. Everglades National Park, Homestead, FL.

Big Cypress Papers

1983 Letter from Michael Watkins, President of Coalition of Concerned Citizens, to Secretary of the Interior James Clark, Dec. 7. BICY 14661. Series I, Box 1. South Florida Collections Management Center. Everglades National Park, Homestead, FL.

Blake, Nelson Manfred

1980 Land into Water - Water into Land: A History of Water Management in Florida. Gainesville, FL: University Presses of Florida. 
Blue Water Network

2001 Environmentalists Intervene in Big Cypress Thrill-Craft Lawsuit. Press Release. March 20. http://www.commondreams.org/news2001/0320-12.htm (Accessed May 11, 2011)

Blythe, Robert

2012 Interview with Joe Browder at Cosmos Club, Washington DC. Feb. 7 transcript. EVER-1892. South Florida Collections Management Center, Everglades National Park, Homestead, FL.

Braun, Bruce

1997 Buried epistemologies: The politics of nature in (post)colonial British Columbia. Annals of Association of American Geographers 87(1): 3-31.

2002 The intemperate rainforest : nature, culture, and power on Canada's west coast. Minneapolis: University of Minnesota Press.

2003 On the Raggedy Edge of Risk: Articulations of Race and Nature After Biology. In Race, Nature and the Politics of Difference, Donald Moore, Jake Kosek and Anand Pandian, eds., Pp. 175-203. Durham, NC: Duke University Press.

Brechin, Steven R., Peter R Wilshusen, Crystal L. Fortwangler and Patrick C. West, eds. 2003 Contested Nature: Promoting International Biodiversity and Social Justice in the Twenty-First Century. Albany: State University of New York Press.

Brosius, J. Peter 1999 "Green Dots, Pink Hearts, Displacing Politics from the Malaysian Rain Forest." American Anthropologist 101.

Brown, Robin C.

1994 Florida’s First Peoples. Revised ed. Pineapple Press: Sarasota, FL.

Bryant, Raymond L. and Sinéad Bailey.

1997 Third World Political Ecology. London: Routledge.

Bucuvalas, Tina, Peggy A. Bulger, and Stetson Kennedy

1994 South Florida Folklife. Folklife in the South Series. Jackson, MS: University Press of Mississippi.

Bunn, Don

2012 Segment Fourteen: 1940 to 1980 Power Wagon Pickups. http://www.pickuptrucks.com/html/history/segment14.html. Accessed Jan. 11, 2012.

Burnham, Philip.

2000 Indian country, God's country : Native Americans and the national parks.

Washington, DC: Island Press. 
Canedy, Dana

2002 Advocates and Drivers Reach Fork in the Off-Road. New York Times, March 24.

Carrier, James and Paige West, eds.

2004 Virtualism, Governance and Practice: Vision and Practice in Environmental Conservation. New York: Berghahn Books.

Casey, Edward

1996 How to Get from Space to Place in a Fairly Short Stretch of Time:

Phenomenological Prolegomena. In Senses of Place. Steven Feld and Keith Basso, eds. Pp. 13-52. Santa Fe, NM: School of American Research Press.

Cattelino, Jessica.

2008 High Stakes: Florida Seminole Gaming and Sovereignty. Durham, NC: Duke University Press.

2009 Florida Seminoles and the Cultural Politics of the Everglades. Occasional Paper from the School of Social Science, Institute for Advanced Study. May: Paper Number 36

Chase, Alston

1997 Some Cautionary Remarks About the Precautionary Principle. Countdown to Kyoto Conference, Canberra, Australia. August 1997.

Clarke, Alice and George Dalrymple 2003 \$7.8 Billion for Everglades Restoration: Why Do Environmentalists Look So Worried? Population and Environment 24(6): 541-569.

Clarke Jeanne N., and Daniel C. McCool 1996 Staking Out the Terrain: Power and Performance among Natural Resource Agencies. Albany: State University of New York Press.

Conklin, Beth 1997 Body Paint, Feathers and VCRs: Aesthetics and Authenticity in Amazonian Activism. American Ethnologist 24(4): 711-737.

Conklin, Beth and Laura Graham

1995 The Shifting Middle Ground: Amazonian Indians and Eco-Politics. American Anthropologist 97:695-710.

Corbetta, Piergiorgio

2003 Social Research: Theory, Methods and Techniques. Thousand Oaks, CA: Sage.

Corbin J. and A. Strauss

2008 Basics of qualitative research: Techniques and procedures for developing 
grounded theory. Thousand Oaks, CA: Sage.

Cronon, William

1995 The Trouble with Wilderness; or, Getting Back to the Wrong Nature. In

Uncommon Ground: Rethinking the Human Place in Nature. William Cronon ed. Pp. 69-90. New York: W. W. Norton \& Co.

Daniels, Stephen and Denis Cosgrove

1988 Introduction: Iconography and Landscape. In The Iconography of Landscape:

Essays on the Symbolic Representation, Design and Use of Past Environments. Denis Cosgrove and Stephen Daniels eds. Cambridge: University of Cambridge Press.

Davenport, John and T. Adam Switalski

2006 Environmental Impacts of Transport, Related to Tourism and Leisure Activities. In The Ecology of Transportation: Managing Mobility for the Environment, John Davenport and Julia Davenport eds., Pp. 333-360. The Netherlands: Springer.

Davis, Jack E

2011 An Everglades Providence: Marjory Stoneman Douglas and the American Environmental Century. Athens, GA: University of Georgia Press.

DeLanda, Manuel

2006 A New Philosophy of Society: Assemblage Theory and Social Complexity. New York: Continuum.

Deleuze, Gilles and Felix Guattari

1987 A Thousand Plateaus. Minneapolis, MN: University of Minnesota Press.

Derr, Mark

1998 Some Kind of Paradise: A Chronicle of Man and the Land in Florida.

Gainesville, FL: University Press of Florida.

Dominy, Michele

1995 White Setter Assertions of Native Status. American Ethnologist 22(2): 358-374.

Douglas, Marjory Stoneman

1947 The Everglades: River of Grass. $60^{\text {th }}$ Anniversary edition with update by Michael Grunwald. Sarasota, FL: Pineapple Press, 2007.

Duever, Michael, John E Carlson and Lawrence A Riopelle 1981 Off-Road Vehicles and Their Impacts in the Big Cypress National Preserve. Report No. T-614. Homestead, FL: National Park Service.

1986 Long term recovery of experimental off-road vehicle impacts and abandoned old trails in the Big Cypress National Preserve. Report No. SFRC-86/09. Homestead, FL: National Park Service. 
Duever, Michael J., John E. Carlson, John F. Meeder, Linda C. Duever, Lance H. Gunderson, Lawrence A. Riopelle, Taylor R. Alexander, Ronald L. Myers and Daniel P. Spangler.

1986 The Big Cypress National Preserve. $2^{\text {nd }}$ printing. Research Report No. 8. New York: National Audubon Society.

Doyle, Mary

2008 "The Everglades." In Large-scale Ecosystem Restoration: Five case studies from the United States. Mary Doyle and Cynthia Drew, eds. Pp. 1-2. Washington, DC: Island Press.

Escobar, Arturo

1995 Encountering Development. Princeton, NJ: Princeton University Press.

2008 Territories of Difference: Place, Movements, Life, Redes. Durham, NC: Duke University Press.

Everglades Coalition

1993 Everglades in the $21^{\text {st }}$ Century: The Water Management Future. Second Printing. 2010 Everglades Coalition 2020 Vision for the Everglades. Jan. 7. Everglades

Coalition Conference. Palm Beach Gardens, FL. January 2010.

Feld, Steven and Keith Basso

1996 Introduction. In Senses of Place. Steven Feld and Keith Basso eds. Pp. 3-12.

Santa Fe, NM: School of American Research Press.

Ferguson, James

1994 The Anti-politics Machine: "Development”, Depoliticization, and Bureaucratic Power in Lesotho. Minneapolis: University of Minnesota Press.

Foucault, Michel

1977 Nietzche, geneaology, history. Trans. Donald F. Bouchard and Sherry Simon. In Language, Counter-Memory, Practice: Selected Essays and Interviews. Donald F. Bouchard, ed. Ithaca, NY: Cornell University Press.

2000a [1982]. "The Subject and Power." In Power: Essential Works of Foucault: 19541984. James D. Faubion ed., and Robert Hurley and others, trans. New York: The New Press.

2000b. [1991] “Governmentality.” In Power: Essential Works of Foucault: 1954-1984. James D. Faubion ed., and Robert Hurley and others, trans. Pp. 326 - 348. New York: The New Press.

Francis, Thomas

2007 Swamp Theme: Everglades' old guard girds for county park fight. Broward-Palm Beach New Times. July 26. http://www.browardpalmbeach.com/2007-0726/news/swamp-theme/www.wolfgangsvault.com/-1/ (Accessed October 26, 2011) 
Gannon, Michael

2003 Florida: A Short History. Revised edition. Gainesville, FL: University Press of Florida.

Glaser, B. and A. Strauss

1967 The Discovery of Grounded Theory: Strategies for Qualitative Research. New York: Aldine.

U.S. Government Accountability Office (U.S. GAO)

2007 South Florida Ecosystem Restoration Is Moving Forward but Is Facing Significant Delays, Implementation Challenges, and Rising Costs. Report for House Committee on Transportation and Infrastructure. Washington, DC: GPO. GAO-07520

Goldman, Mara J. and Matthew D. Turner 2011 Introduction. In Knowing Nature: Conversations at the Intersection of Political Ecology and Science Studies, Mara J. Goldman, Paul Nadasdy and Matthew D. Turner, eds. Chicago: University of Chicago Press.

Goss, James A.

1995 Usual and Customary Use and Occupancy by the Miccosukee and Seminole Indians in Big Cypress National Preserve, Florida. Project Report D-121. Atlanta, GA: U.S. National Park Service, Southeast Region.

Gordillo, Gaston

2004 Landscapes of Devils: Tensions of Place and Memory in the Argentinean Chaco. Durham, NC: Duke University Press.

Gore, Rick

1976 “Twilight Hope for Big Cypress.” National Geographic 150 (2): 251-273.

Gregory, Derek.

1994 Geographical Imaginations. Cambridge: Blackwell.

Grunwald, Michael

2006 The Swamp: The Everglades, Florida, and the Politics of Paradise. New York: Simon and Schuster.

Gupta, Akhil and James Ferguson

1997 Beyond Culture: Space, Identity and the Politics of Difference. In Culture, Power, Place: Explorations in Critical Anthropology, Akhil Gupta and James Ferguson eds., Pp. 33-51. Durham, NC: Duke University Press. 
Haenn, Nora

2005 Fields of Power, Forests of Discontent: Culture, Conservation and the State in Mexico. Tucson: University of Arizona Press.

Haraway, Donna

2008 When Species Meet. Minneapolis, MN: University of Minnesota Press.

Harvey, David

1996 Justice, Nature and the Geography of Difference. Wiley-Blackwell.

Heatherington, Tracey

2010 Wild Sardinia: Indigeneity and the Global Dreamtimes of Environmentalism. Seattle, WA: University of Washington.

Hegewald, Jeffrey

2010 Miccosukees and the Tamiami Trail Bridge: Examining the Tribe's Attempts to Sink the Modified Waters Delivery Project. University of Miami School of Law.

Helford, Reid

2000 Constructing Nature as Constructing Science: Expertise, Activist Science, and Public Conflict in the Chicago Wilderness. In Restoring Nature: Perspectives from the Social Sciences and Humanities, Paul Gobster and R. Bruce Hull eds., Pp. 119142. Washington, D.C.: Island Press.

Herzfeld, Michael

2001 Anthropology: Theoretical Practice in Culture and Society. Wiley-Blackwell.

Higgs, Eric

2003 Nature by Design. Cambridge, MA: MIT Press.

Hodgson, Dorothy

2002 Introduction: Comparative perspectives on the indigenous rights movement in Africa and the Americas. American Anthropologist 104(4): 1037-1049.

Hollander, Gail M.

2005 The Material and Symbolic Role of the Everglades in U.S. National Politics.

Political Geography 24:449-475.

2008 Raising Cane in the 'Glades: The Global Sugar Trade and the Transformation of Florida. Chicago: The University of Chicago Press.

Hughes, David McDermott

2006 Hydrology of Hope: Farm dams, conservation, and whiteness in Zimbabwe. American Ethnologist 33(2): 269-287 
Hull, R. Bruce and David Robertson

2000 Conclusion: Which Nature? In Restoring Nature: Perspectives from the Social Sciences and Humanities, Paul Gobster and R. Bruce Hull eds., Pp. 299-307.

Washington, D.C.: Island Press.

Igoe, Jim.

2004 Conservation and Globalization : a Study of National Parks and Indigenous

Communities from East Africa to South Dakota. Case Studies on Contemporary Social Issues. Belmont, CA: Thomson/Wadsworth.

Jacoby, Karl

2001 Crimes Against Nature: Squatters, Poachers, Thieves and the Hidden History of American

Kautz, R., R. Kawula, T. Hoctor, J. Comiskey, D. Jansen, D. Jennings, J. Kasbohm, F. Mazzotti, R. McBride, L. Richardson, and K. Root

2006 How much is enough? Landscape-scale conservation for the Florida panther.

Biological Conservation 130:118-133.

Keller Robert and Michael Turek

1998 American Indians and National Parks. Tucson: University of Arizona Press.

Kennedy, Stetson

2009 Palmetto Country. Cocoa, FL: Florida Historical Society Press.

Kersey Jr., Harry A.

1975 Pelts, Plumes and Hides: White Traders Among the Seminole Indians, 1870-

1930. Gainesville: University of Florida Presses.

Kline, Benjamin

2007 First Along the River : a Brief History of the U.S. Environmental Movement. Lanham, MD: Rowman \& Littlefield.

Kosek, Jake 2006 Understories: The Political Life of Forests in New Mexico. Durham, NC: Duke University Press.

Kraft, Michael E.

2001 Environmental Policy and Politics. New York: Longman.

Latour, Bruno

1986 Visualization and cognition: Thinking with eyes and hands. In Knowledge and Society: Studies in the Sociology of Culture Past and Present, eds. Henrika Kulchek and Elizabeth Long, 1-40. London: JAI Press.

1999 Pandora's Hope: Essays on the Reality of Science Studies. Cambridge, MA:

Harvard University Press. 


\section{Li, Tanya}

2007 The Will to Improve. Durham, NC: Duke University Press.

Light, Alfred

2006 Tales of the Tamiami Trail: Implementing Adaptive Management in Everglades Restoration. Journal of Land Use 22(1): 59-99.

\section{Lowenthal, David}

1996 Possessed by the Past: The Heritage Crusade and the Spoils of History. New York: The Free Press.

Marquardt, William H.

1992 Culture and Environment in the Domain of the Calusa. Monograph No. 1. Institute of Archaeological and Paleo-Environmental Studies: Gainesville, FL.

\section{Matthews, Andrew}

2011 Instituting Nature: Authority, Expertise and Power in Mexican Forests. Cambridge, MA: The MIT Press.

McCally, David

1999 The Everglades: An Environmental History. Gainesville: University of Florida Press.

Memory, Melissa and Laura Ogden

2012 [In preparation] Cultural Landscape of Everglades National Park: Ethnographic Overview and Assessment Report. U.S. National Park Service, Everglades National Park, Homestead, FL.

Milanich, Jerald

1998 Florida's Indians from Ancient Times to the Present. University Presses of Florida: Gainesville, FL.

Milton, Kay 1996 Environmentalism and Cultural Theory: Exploring the role of anthropology in environmental discourse. New York: Routledge.

Mitchell, Timothy

2002 Rule of Experts. Berkeley, CA: University of California Press.

Mitchell, W.T.

2002 Landscape and Power. $2^{\text {nd }}$ ed. Chicago: University of Chicago Press. 
Moore, Donald

2005 Suffering for Territory: Race, Place and Power in Zimbabwe. Durham, NC: Duke University Press.

Morse, Janice

1994 Designing funded qualitative research. In Handbook for qualitative research, N. Denzin and Y. Lincoln eds., Pp. 220-35. Thousand Oaks, CA: Sage.

Nadasdy, Paul

2004 Hunters and Bureaucrats: Power, Knowledge and Aboriginal-State Relations in the Southwest Yukon. Vancouver: UBC Press.

(NARA) National Archives and Records Administration II

IIa Assorted Letters and Papers. RG 79, NPS Central Classified Files, Subseries 2 (PI 166 7.ZZ1): Box 900 - Everglades - General.

IIb Ernest Coe to the Honorable Ed Pou, Chairman Committee of Rules, House of Representatives, February 1933. RG 79, NPS Central Classified Files, Subseries 2 (PI 166 7.ZZ1): Box 903 - 120 - Legislation.

(NAS) Committee on Independent Scientific Review of Everglades Restoration Progress, National Research Council, National Academy of Sciences

2008 Progress toward restoring the Everglades: The second biennial review.

Washington, DC: National Academies Press.

2010 Progress toward restoring the Everglades: The third biennial review. Washington, DC: National Academies Press.

2012 Progress toward restoring the Everglades: The fourth biennial review.

Washington, DC: National Academies Press.

National Parks Conservation Association (NPCA)

2011 National Parks Conservation Association Files Suit Against Park Service for Failure to Protect Big Cypress National Preserve in Florida. NPCA Press Release. October 12.

http://www.npca.org/media_center/press_releases/2011/big_cypress_suit_101211.ht $\mathrm{ml}$ (Accessed October 24, 2011 )

New York Times

2002 Nature Overrun. Editorial. April 4.

Neumann, Roderick P.

2005 Making Political Ecology. New York: Oxford University Press.

1998 Imposing Wilderness. Berkeley, CA: University of California Press.

U.S. National Park Service (NPS)

2000 Final Recreational Off-Road Vehicle Management Plan and Supplemental

Environmental Impact Statement. Big Cypress National Preserve, Florida. 
2006 East Everglades Expansion Area. Everglades National Park General Management Plan Newsletter 3. June.

2010 Everglades National Park Tamiami Trail Modifications: Next Steps.

Environmental Impact Statement.

New South and Associates (NSA)

2006 A Cultural Resources Survey, Tamiami Trail, Modified Waters to the Everglades National Park -GRR/SEIS. Final Report. January 11. Stone Mountain, GA. Technical Report 1272.

2011 You Just Can't Live Without It. Ethnographic Study and Evaluation of

Traditional Cultural Properties of the Gladesmen Culture. Revised Draft. July 17. St. Augustine, FL. Technical Report 1688.

Ogden, Laura

2008a The Everglades Ecosystem and the Politics of Nature. American Anthropologist 110(1): 21-32.

2008b Searching for Paradise in the Florida Everglades. Cultural Geographies 15: 207-229.

2011 Swamplife: People, Gators and Mangroves Entangled in the Everglades. Minneapolis: University of Minnesota Press.

Olwig, Kenneth

2002 Landscape, nature, and the body politic : from Britain's renaissance to America's new world. Madison: University of Wisconsin Press.

Orlove, Ben and Steven Caton

2010 Water Sustainability: Anthropological Approaches and Prospects. Annual

Review of Anthropology 39:401-415.

Peet, Richard and Michael Watts

2004 Liberating Political Ecology. In Liberation Ecologies. $2^{\text {nd }}$ ed. Richard Peet and Michael Watts, eds. Pp. 3-47. New York: Routledge.

Peterman, Audrey and Frank.

2003 African Americans and the Sawmills of Big Cypress: A Brief History. Contract \# P5120021078. U.S. National Park Service, Big Cypress National Preserve, Ochopee, FL.

Peters, Sarah

2007 Conservation Groups Take NPS to Court over Damaging Off-Road Vehicle Use in Big Cypress National Preserve. Wildlands CPR Press Release. Dec. 21. http://www.wildlandscpr.org/our-news/big-cypress-national-preserve -threateneddamaging-off-road-vehicle-use (Accessed October 25, 2011) 
Raffles, Hugh

1999 In Amazonia: A Natural History. Princeton, NJ: Princeton University Press.

Ragin, Charles

1994 Constructing Social Research: The Unity and Diversity of Method. Thousand Oaks, CA: Pine Forge Press.

Ray, Celeste

2001 Highland Heritage: Scottish Americans in the American South. Chapel Hill, NC:

The University of North Carolina Press.

Reisner, Mark

1993 Cadillac Desert: The American West and its Disappearing Water. Revised Edition. New York: Penguin Books.

Repanshek, Kurt

2007a Big Cypress: Wilderness or ORVs? National Parks Traveler.April 23. http://www.nationalparkstraveler.com/2007/04/big-cypress-wilderness-or-orvs (Accessed October 26, 2011)

2007b Ruts in Big Cypress, Wilderness And Endangered Species. National Parks

Traveler. May 6. http://www.nationalparkstraveler.com/2007/05/ruts-big-cypress-

wilderness-and-endangered-species (Accessed October 26, 2011)

Riesenweber, Julie

2008 Landscape Preservation and Cultural Geography. In Cultural Landscapes, Richard Longstreth, ed., Pp. 23-34. Minneapolis: University of Minnesota Press.

Robbins, Paul

2004 Political Ecology. Malden, MA: Blackwell Publishing.

Runte, Alfred

1979 National Parks: the American Experience. Lincoln: University of Nebraska Press.

Rupp, Stephanie

2011. Forests of Belonging. Seattle, WA: University of Washington Press.

Russell, Nancy.

2007 Interview with Joe Browder in Everglades City. Dec. 7 transcript. EVER-1410.

South Florida Collections Management Center, Everglades National Park,

Homestead, FL.

Ryan, Gery and H. Russell Bernard

2003 Techniques to Identify Themes. Field Methods 15(1):85-109. 
Said, Edward

1979 Orientalism. Vintage Books.

Salt, Terrence "Rock," Stuart Langton and Mary Doyle

2008 "The Challenges of Restoring the Everglades Ecosystem." In Large-scale

Ecosystem Restoration: Five case studies from the United States, eds. Mary Doyle and Cynthia Drew, 5-33. Washington, DC: Island Press.

Sayre, Nathan F.

2005 Ranching, Endangered Species and Urbanization in the Southwest: Species of Capital. Tucson, AZ: University of Arizona Press.

Scott, James C.

1998 Seeing Like a State : How Certain Schemes to Improve the Human Condition Have Failed. Yale Agrarian Studies. New Haven: Yale University Press.

Society for Ecological Restoration International Science and Policy Working Group (SER)

2004 The SER International Primer on Ecological Restoration. Tucson, AZ: Society for Ecological Restoration International.

South Florida Ecosystem Restoration Task Force (SFERTF)

2000 Coordinating Success: Strategy for Restoration of the South Florida Ecosystem. Miami: South Florida Ecosystem Restoration Task Force

Sierra Club

2009 Addendum to Comments on Tamiami Trail Next Steps and the Restoration of Shark River Slough. June 29.

Simmons, Glen, and Laura Ogden.

1998 Gladesmen: Gator Hunters, Moonshiners and Skiffers. The Florida History and

Culture Series. Gainesville, FL: University Press of Florida.

Slater, Candace

2003 Entangled Edens: Visions of the Amazon. Berkeley, CA: University of California Press.

Spence, Mark David

1999 Dispossessing the wilderness: Indian removal and the making of the national parks. New York: Oxford University Press.

Ste. Claire, Dana

1998 Cracker: The Cracker Culture in Florida History. Daytona Beach, FL: The Museum of Arts and Sciences. 
Stone, Cal R.

1979 Forty Years in the Everglades. Tabor City, NC: Atlantic Publishing Co.

Strang, Veronica

2003 Moon Shadows: Aboriginal and European Heroes in an Australian Landscape. Pamela Stuart and Andrew Strathern, eds. Pp. 108-135. Sterling, VA: Pluto Press. 2004 The Meaning of Water. New York, NY: Berg.

Tebeau, Charlton

1968 Man in the Everglades: 2000 Years of Human History in the Everglades National Park. $2^{\text {nd }}$ ed. University of Miami Press.

1977[1957] Florida's Last Frontier: The History of Collier County. Paperback edition. Copeland Studies in Florida History, No. 1. Miami, FL: University of Miami Press.

Tiger, Buffalo and Harry A. Kersey Jr.

2002 Buffalo Tiger: A Life in the Everglades. Lincoln, NB: University of Nebraska Press.

Tsing, Ana

2005 Friction: An Ethnography of Global Connection. Princeton: Princeton University Press.

U.S. Congress.

1974a. Senate Committee on Interior and Insular Affairs. Senate Report 93-1128. $93^{\text {rd }}$ Congress. $2^{\text {nd }}$ Session.

$1974 b$

1974c Senate. Establishing the Big Cypress National Preserve, Florida. August 22. $93^{\text {rd }}$ Cong., $2^{\text {nd }}$ Sess. House Report 93-502.

United States of America, et al. v. South Florida Water Management District

1991 Settlement Agreement, 26 July 1991. Case No. 88-1886-CIV-Hoeveler

URS Corporation

2009 Public Scoping Report. Everglades National Park Tamiami Trail Modifications:

Next Steps.

U.S. Fish and Wildlife Service (USFWS)

1999 Pine Rocklands. In Multi-Species Recovery Plan for South Florida: Ecological

Communities. Bethesda, MD: U.S. Fish and Wildlife Service Reference Service.

2008 Florida Panther Recovery Plan (Puma concolor coryi). $3^{\text {rd }}$ Revision. Atlanta, GA:

U.S. Fish and Wildlife Service, Southeast Region.

Vileisis, Ann

1997 Discovering the Unknown Landscape: A History of America's Wetlands.

Washington, D.C.: Island Press. 
Walley, Christine

2004 Rough Waters: Nature and Development in an African Marine Park. Princeton: Princeton University Press.

Weisman, Brent Richards

1999 Unconquered People: Florida's Seminole and Miccosukee Indians. Gainesville, FL: University Press of Florida.

West, Paige

2006 Conservation is Our Government Now. Durham, NC: Duke University Press.

West, Paige, Jim Igoe and Dan Brockington

2006 Parks and Peoples: The Social Effects of Protected Areas. Annual Review of Anthropology 20 (3): 609-616.

West, Patsy

1998 The Enduring Seminoles: From Alligator Wrestling to Ecotourism. University Press of Florida.

Wiedman, Dennis

2010 Global Marketing of Indigenous Culture: Discovering Native America with Lee Tiger and the Florida Miccosukee." American Indian Culture and Research Journal 34 (3): 1-26.

Worster, Donald

1985 Rivers of Empire: Water, Aridity and the Growth of the American West. New York, NY: Oxford University Press.

Wuerthner, George

2007 Thrillcraft: The Environmental Consequences of Motorized Recreation.

Foundation for Deep Ecology.

Wylie, John

2009 Landscape, Absence and the Geographies of Love. Transactions of the Institute of British Geographers 34: 275-289.

Young, S. P. and E. A. Goldman

1946 The Puma - Mysterious American Cat. Washington, DC: American Wildlife Institute.

Yung, Laurie, Wayne A. Freimund and Belsky, Jill M.

2003 The Politics of Place: Understanding Meaning, Common Ground and Political Differences on the Rocky Mountain Front. Forest Science 46(6):8-21. 
VITA

\section{REBECCA I. GARVOILLE}

Born, Prairie du Sac, Wisconsin

2000-2004

B.S., Regional Development

University of Arizona

Tucson, Arizona

2004-2005

Americorps Volunteer

Wenatchee, Washington

2006-2007

Regional Environmental Planner

South Florida Regional Planning Council

Hollywood, FL

2008-2009

Policy Fellow, National Parks Conservation Association Hollywood, FL.

M.A., Comparative Sociology

Florida International University

Miami, FL

2010

Policy Fellow, Everglades Foundation

Palmetto Bay, FL.

2007-2013

Doctoral Candidate

Florida International University

Miami, FL

Research Assistant, Human Dimensions Group

NSF Florida Coastal Everglades Longterm Ecological

Research (FCE-LTER) Program

Florida International University, Miami, FL

\section{PUBLICATIONS AND PRESENTATIONS}

Garvoille, Rebecca. 2012. The Devil is in the Details: Ecosystem Restoration and the Cultural Politics of Heritage in the Florida Everglades. American Anthropological Association Annual Meeting, San Francisco, CA, Nov. 2012. 
Garvoille, Rebecca. 2012. Invited Participant. Conceptualizing Authenticity in Ecosystem Restoration: Contested Cultural Histories and the Rise of the Gladesmen Folk Culture in the Florida Everglades. Workshop on History and Values in Ecological Restoration. Colorado College, Colorado Springs, CO, June 2012.

Garvoille, Rebecca. 2012. Encountering Culture in Restoration: Understanding Cultural Tensions in the Florida Everglades and Beyond. INTECOL International Wetlands and Greater Everglades Ecosystem Restoration Conference, Orlando, FL, June 2012.

Garvoille, Rebecca. 2012. Whose Everglades? Whose Heritage?: The Cultural Politics of Nature and the Rise of the Gladesmen Folk Culture in the Florida Everglades.

Dimensions of Political Ecology Conference, Lexington, KY, April 2012.

Garvoille, Rebecca. 2011. Whose Everglades? Whose Whiteness? The Contemporary Landscape Politics of Belonging in the Florida Everglades. American Anthropological Association Annual Meeting, Montreal, Canada, Nov. 2011.

Garvoille, Rebecca. 2011. Conflict and Contestation in the Florida Everglades: An Anthropologist's Take on Ecosystem Restoration Tradeoffs. Coastal and Estuarine Research Federation Annual Meeting, Daytona Beach, FL, Nov. 2011.

Garvoille, Rebecca, John Ogden, Laura Ogden, Rosanna Rivero and Tom Van Lent. 2011. Defining Restoration Success. Everglades Coalition Annual Meeting, Weston, FL, Jan. 2011.

Harris, Edmund M., Colin Polsky, Kelli L. Larson, Rebecca Garvoille, Deborah Martin, Jaleila Brumand and Laura Ogden. 2012. Heterogeneity in Residential Landscape Management: Evidence from Boston, Miami, and Phoenix. Human Ecology 40(5): 735749.

Romolini, Michele, Sydne Record, Rebecca Garvoille, R. Stuart Geiger, and Yevgeniy Marusenko. 2013. The Next Generation of Scientists: Examining the Experiences of Graduate Students in Network-Level Science. Ecology and Society. (In review)

AWARDS

2012

2012

2011

2011
NSF Doctoral Dissertation Improvement Grant

FIU Dissertation Year Fellowship

FIU Dissertation Evidence Acquisition Fellowship

FIU Morris and Anita Broad Research Fellowship 